\title{
Control de calidad y seguridad de la carne y productos cárnicos curados mediante el uso de sensores enzimáticos
}

Tesis Doctoral

Presentada por:

Aleida Selene Hernández Cázares

Dirigida por:

Prof. Dr. Fidel Toldrá Vilardell

Dra. Ma Concepción Aristoy Albert

Valencia, Octubre de 2010 



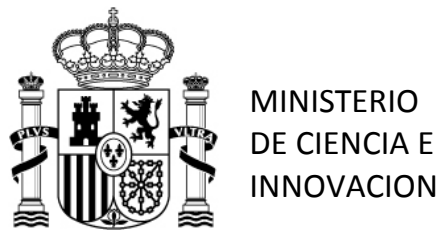

D. Fidel Toldrá Vilardell, Profesor de Investigación del Consejo Superior de Investigaciones Científicas (CSIC) en el Instituto de Agroquímica y Tecnología de Alimentos (IATA) y Dña. Ma Concepción Aristoy Albert, Investigador Titular de OPIs del el mismo Instituto,

HACEN CONSTAR: Que el trabajo de investigación titulado "Control de calidad y seguridad de la carne y productos cárnicos curados mediante el uso de sensores enzimáticos" que presenta Dña. ALEIDA SELENE HERNÁNDEZ CÁZARES para optar al grado de Doctor por la Universidad Politécnica de Valencia, ha sido realizada bajo su dirección y supervisión en el Instituto de Agroquímica y Tecnología de Alimentos, reuniendo las condiciones necesarias para optar al grado de Doctor.

Valencia, 1 de Octubre de 2010

Fdo. Prof. Dr. Fidel Toldrá Vilardell

www. iata.csic.es
Fdo. Dra. Ma Concepción Aristoy Albert 



\section{Resumen}

Inmediatamente después del sacrificio del animal, se inician en la carne un gran número de cambios bioquímicos que son críticos para definir el desarrollo de la calidad. La evaluación de algunos metabolitos derivados de estos procesos ha sido propuesta como método rápido y simple para determinar la calidad de la carne y de los productos cárnicos. Actualmente, la técnica más utilizada en la detección de estos compuestos es la cromatografía líquida de alta resolución (HPLC). Sin embargo, el creciente interés de la industria, especialmente del sector alimentario, por realizar un control de calidad más rápido y económico, demanda métodos analíticos que sean compatibles con sus necesidades y que puedan ser usados en línea. En este contexto, el desarrollo de sensores enzimáticos de tipo amperométrico juega un papel muy importante y suponen una herramienta útil en el control de la calidad y la seguridad alimentaria. En la presente Tesis Doctoral se han desarrollado dos sensores enzimáticos, utilizando principios simples de construcción, para su aplicación en la determinación de hipoxantina $(\mathrm{Hx})$ y aminas biógenas $(\mathrm{AB})$, como marcadores de frescura, maduración y seguridad, en la carne y en productos cárnicos (embutido fermentado y jamón curado). El sensor enzimático consistió de un oxímetro en combinación de una enzima libre o inmovilizada. Las enzimas utilizadas fueron la xantina oxidasa (XO) para la determinación de Hx y la diamina oxidasa (DAO) para la determinación de AB. Además, los sensores enzimáticos fueron validados, correlacionando sus resultados con los obtenidos por HPLC, como método de referencia. Cabe destacar que se desarrolló un nuevo método rápido de análisis de nucleótidos y sus derivados basado en la cromatografía líquida de interacción hidrofílica (HILIC), siendo este una alternativa muy interesante a los métodos ya existentes. 



\begin{abstract}
Immediately after the animal is slaughter, a large number of biochemical changes in the meat take place, which are critical to characterise the quality development. The evaluation of some metabolites derived from these processes has been proposed as a rapid and simple method to determine the quality of meat and meat products. Currently, the high performance liquid chromatography (HPLC) is the technique commonly used in the detection of these compounds. However, the demands of the food industry for a rapid and cheap quality control require analytical methods that can be used on-line. In this sense, enzyme-based amperometric biosensors play a very important role and mean a useful tool for quality control and food safety. In the present Thesis, two enzyme sensors using simple principles of construction have been developed to determine hypoxanthine $(\mathrm{Hx})$ and biogenic amines $(\mathrm{BA})$, as markers of freshness, ripeness and safety in meat and meat products (fermented sausage and cured ham). The enzyme sensor consisted of an oximeter in combination with a free or immobilized enzyme. The enzymes xanthine oxidase (XO) and diamine oxidase (DAO) were used for the determination of $\mathrm{Hx}$ and $\mathrm{BA}$, respectively. Furthermore, enzymatic sensors were validated, by correlating their results with those obtained by HPLC as reference method. In addition, a new rapid method for analysis of nucleotides and their derivatives was developed based on hydrophilic interaction chromatography (HILIC), which could be used as a very interesting alternative to current methods.
\end{abstract}





\section{Resum}

Immediatament després del sacrifici de l'animal, s'inicien en la carn un gran nombre de canvis bioquímics que són crítics per tal de definir el desenvolupament de la qualitat. L'avaluació d'alguns metabolits derivats d'aquestos processos ha estat proposada com a mètode ràpid i simple per tal de determinar la qualitat de la carn $\mathrm{i}$ dels productes càrnics. Actualment, la tècnica més emprada en la detecció d'aquests compostos és la cromatografia líquida d'alta resolució (HPLC). No obstant això, el creixent interés de la indústria, especialment del sector alimentari, per realitzar un control de qualitat més ràpid i econòmic, demanda mètodes analítics compatibles amb les seves necessitats i que puguen ser utilitzats en línia. En aquest context, el desenvolupament de sensors enzimàtics de tipus amperomètric juga un paper molt important i suposa una ferramenta útil en el control de la qualitat i la seguretat alimentària. En la present Tesi Doctoral s'han desenvolupat dos sensors enzimàtics, utilitzant principis simples de construcció, per a la seua aplicació en la determinació de hipoxantina $(\mathrm{Hx})$ i amines biògenes $(\mathrm{AB})$, com a marcadors de frescor, maduració $\mathrm{i}$ seguretat, en la carn i en productes càrnics (embotit fermentat i pernil curat). El sensor utilitzat va consistir en un oxímetre en combinació amb l'enzim lliure o immobilitzada. Les enzimes utilitzades van ser la xantina oxidasa (XO) per a la determinació de Hx i la diamina oxidasa (DAO) per a la determinació de AB. A més, els sensors enzimàtics van ser validats, correlacionant els seus resultats amb els obtinguts per HPLC, com a mètode de referència. Cal destacar que es va desenvolupar un nou mètode ràpid d'anàlisi de nucleòtids $i$ derivats basat en la cromatografia líquida d'interacció hidrofílica (HILIC), sent aquest una alternativa molt interessant als mètodes ja existents. 

A mis padres 



\section{Agradecimientos}

A mis directores, el Dr. Fidel Toldrá Villardel y la Dra. Mạ Concepción Aristoy Albert, por darme la oportunidad de realizar esta Tesis, confiar en mí y apoyarme en todo momento. El más profundo y sincero agradecimiento por su valiosa ayuda en mi formación profesional e investigadora.

Al Colegio de Postgraduados (C.P.) y al Consejo Nacional de Ciencia y Tecnología (CONACYT) de México por la beca otorgada y hacer posible la realización de mis estudios de Doctorado. Asimismo, agradezco al Ministerio de Ciencia e Innovación de España, através del proyecto AGL-2007-65379-C02-01 y al proyecto Agroalimed de la Consellería de Agricultura, Pesca y Alimentación la financiacion recibida para la realización de este trabajo.

A la Dra. Mónica Flores, al Dr. Miguel Ángel Sentandreu y al Dr. Jose Luis Navarro por su colaboración y su disponibilidad a resolver mis inquietudes.

Al personal Técnico del laboratorio de Carnes, Ma Pilar, Maribel y $M$ todos aquellos estudiantes de prácticas y proyectos de fin de carrera, por su ayuda y buenos momentos que compartimos.

A mis compañeros de laboratorio, para quienes ya se han ido y para los que se quedan, que durante estos años han compartido conmigo su amistad y me han brindado sus consejos y apoyo: Alicia, Eli, Susana, Patricia, Mónica, Liliana, Sara y Carlos. A Leticia Mora por su amistad, ayuda y colaboración en el desarrollo de este trabajo.

A mis hermanos Edna e Iván y mis sobrinos Zaid, Axel, Aleida y Camila, porque a pesar de la distancia, el ánimo y alegrias que me brindan me dieron la fortaleza para continuar y seguir adelante. 
A mis amigos: Rogelio, Mayte, Joel Ramón, Cynthia, Marcela, Thalia y Guillermo por estar siempre ahí, aunque en la distancia a lo largo de este proceso, su apoyo, ánimo y consejos fueron de gran ayuda para mí. A Adriana, Rocio y Carlos por su amistad,

confianza, apoyo y sobre todo por esos buenos momentos y experiencias compartidas durante mi estancia en esta ciudad. 


\section{ÍNDICE}

1. Introducción.

3

1.1. Calidad de la carne de cerdo y sus productos cárnicos.

1.1.1. Carne.

1.1.2. Embutidos curados fermentados.

1.1.2.1. Importancia del proceso de fabricación

1.1.3. Jamón curado.

1.1.3.1. Importancia del proceso de fabricación.

1.2. Principales cambios bioquímicos en la carne y productos cárnicos curados durante la maduración.

1.2.1 Glucólisis

1.2.2.Proteolisis

1.2.3. Lipólisis.

1.2.4. Transformación de nucleótidos y nucleósidos.

1.2.5. Generación de aminas biógenas

1.2.6. Otros cambios debidos a reacciones químicas

1.3. Métodos analíticos para la determinación de nucleótidos y sus derivados y de aminas biógenas en la carne y productos cárnicos

1.3.1. Nucleótidos y sus derivados

1.3.2. Aminas biógenas

1.4. Biosensores

1.4.1. Clasificación de los biosensores por su elemento de reconocimiento...

1.4.1.1. Biosensores catalíticos.

1.4.1.2. Biosensores por afinidad

1.4.2. Clasificación de los biosensores por su tipo de transducción.

1.4.2.1. Biosensores electroquímicos.

1.4.2.2. Biosensores ópticos

1.4.2.3. Biosensores térmicos.

1.4.2.4. Biosensores piezoeléctricos 17

4

4

9 10

12

14 17 19 24 26 30 33 35 35 37 38 39 39 40 40 40 43 44 44 


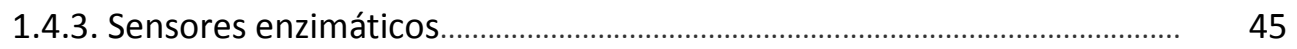

1.4.3.1. Inmovilización de la enzima......................................................................... 48

1.4.3.1.1. Materiales soporte para la inmovilización de la enzima..... $\quad 49$

1.4.3.1.2. Materiales de construcción del transductor............................. 51

1.4.3.2. Principio de operación................................................................................. 51

1.4.4. Aplicación de los sensores enzimáticos en el sector cárnico...................... 53

2. Objetivos

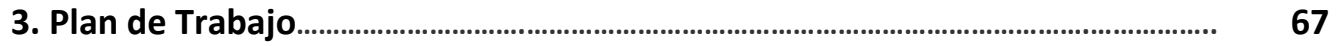

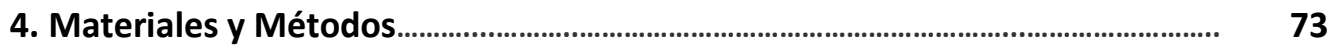

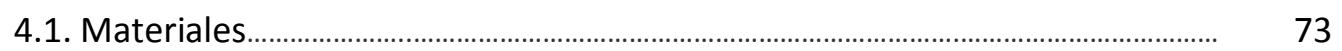

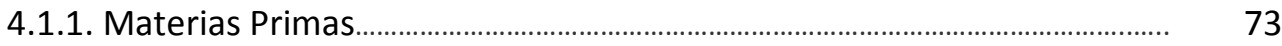

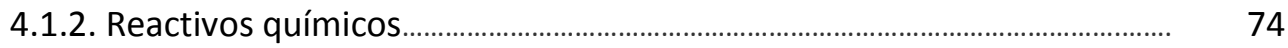

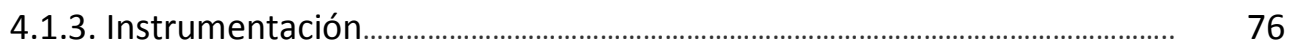

4.2. Métodos de fabricación, seguimiento y obtención de muestras........................ 77

4.2.1. Maduración de la carne........................................................................................... 77

4.2.2. Fabricación del embutido fermentado curado................................................. 78

4.2.3. Fabricación del jamón curado.............................................................................. 80

4.3. Métodos analíticos.............................................................................................................. 83

4.3.1. Extracción de nucleótidos y sus derivados............................................................ 83

4.3.2. Determinación de nucleótidos y sus derivados por HPLC.............................. 84

4.3.2.1. Análisis en carne.............................................................................................. 84

4.3.2.1.1. Cromatografía en fase reversa con par iónico (IP-RP-HPLC). 84

4.3.2.1.2. Cromatografía de interacción hidrofílica (HILIC)......................... 84

4.3.2.2. Análisis en productos curados.......................................................................... 86

4.3.2.2.1. Cromatografía en fase reversa (RP-HPLC)...................................... 86

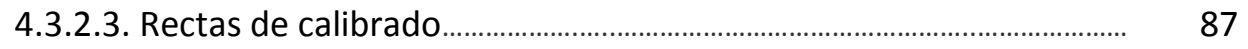

4.3.3. Determinación de hipoxantina con el sensor enzimático............................. 88

4.3.3.1. Sistema enzimático con la enzima libre.................................................... 90 
4.3.3.1.1. Evolución de la reacción enzimática.................................................. 91

4.3.3.2. Sistema enzimático con la enzima inmovilizada.................................. 91

4.3.3.2.1. Inmovilización de la enzima xantina oxidasa................................. 91

4.3.3.3. Ensayos de validación del sensor enzimático......................................... 93

4.3.4. Extracción de aminas biógenas.......................................................................... 94

4.3.5. Determinación de aminas biógenas en productos curados por IP-RPHPLC y derivatización post-columna....................................................................... 94

4.3.6. Determinación de aminas biógenas con el sensor enzimático.................. 95

4.3.6.1. Inmovilización de la enzima diamina oxidasa........................................ 96

4.3.6.2. Ensayos de validación del sensor enzimático.......................................... 97

4.4. Análisis estadístico de resultados........................................................................ 98

5. Resultados y Discusión.............................................................................................. 101

5.1. Puesta a punto y optimización del sensor enzimático............................................ 102

5.1.1.Sensor enzimático con la enzima xantina oxidasa....................................... 103

5.1.1.1. Sistema enzimático con la enzima libre.................................................. 105

5.1.1.2. Sistema enzimático con la enzima inmovilizada................................... 111

5.1.1.3. Estudio de la oxidación de la hipoxantina.......................................... 118

5.1.2. Sensor enzimático con la enzima diamina oxidasa........................................... 119

5.1.2.1. Inmovilización de la enzima diamina oxidasa....................................... 121

5.2. Evolución nucleótidos y sus derivados analizados por HPLC en la carne y productos cárnicos.............................................................................................. 128

5.2.1. Maduración de la carne .................................................................................... 129

5.2.1.1. Evolución de nucleótidos y sus derivados por IP-RP-HPLC............... 131

5.2.1.2. Optimización del método cromatográfico HILIC ..................................... 135

5.2.1.2.1. Carne fresca ......................................................................................... 135

5.2.1.2.2. Productos cárnicos.............................................................................. 143

5.2.2. Proceso de curado de un embutido fermentado......................................... $\quad 144$

5.2.2.1. Evolución de los parámetros fisicoquímicos............................................. 146

5.2.2.2. Evolución de nucleótidos y sus derivados por RP-HPLC.................... 149 
5.2.3. Proceso de curado de jamón .............................................................................. 154

5.2.3.1. Evolución de los parámetros fisicoquímicos......................................... 155

5.2.3.2. Evolución de nucleótidos y sus derivados por RP-HPLC...................... 157

5.3. Determinación de hipoxantina con el sensor enzimático y su correlación con los valores obtenidos por análisis cromatográfico....................................... 162

5.3.1. Maduración de la carne .................................................................................... 163

5.3.2. Proceso de curado de un embutido fermentado......................................... 167

5.3.3. Proceso de curado de jamón............................................................................... 173

5.4. Determinación de la generación de aminas biógenas en los productos cárnicos por HPLC

5.4.1. Embutidos fermentados curados..................................................................... 177

5.4.2. Jamón curado........................................................................................................... 183

5.5. Determinación de aminas biógenas en los productos cárnicos analizados con el sensor enzimático y su correlación con HPLC........................................................ 187

5.5.1. Embutidos fermentados curados......................................................................... 187

5.5.2. Jamón curado ............................................................................................................... 188

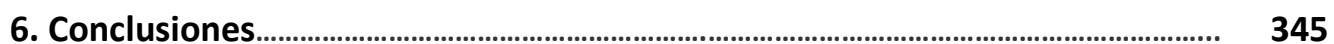

7. Bibliografía ......................................................................................................................... 195

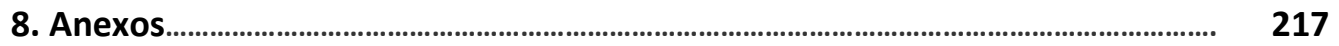

A. Hypoxanthine-based enzymatic for determination of pork meat............................. 219

B. Hydrophilic interaction chromatographic determination of adenosine triphosphate and its metabolites

C. Hydrophilic interaction chromatographic (HILIC) in the analysis of relevant quality and safety biochemical compounds in meat, poultry and processed meats...

D. Nucleotides and its derivated compounds during the processing of dry-cured ham and its detection with an enzyme sensor.. 


\section{Lista de figuras}

Figura

1 Diagrama de flujo de la elaboración de embutidos crudos curados fermentados

2 Diagrama de flujo de la elaboración del jamón curado...............................................

3 Proceso de glucólisis en condiciones aerobias y anaerobias.................................. 19

4 Esquema general de la proteolisis y las reacciones de transformación de los aminoácidos libres.......................................................................................................... 20

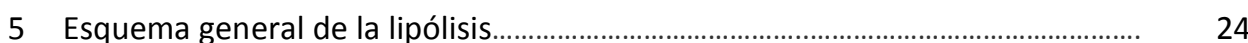

6 Estructura química de los nucleósidos y nucleótidos..................................................... 26

7 Esquema de la degradación del ATP en el músculo post-mortem.......................... 28

8 Ruta metabólica de la formación de aminas biógenas.............................................. 32

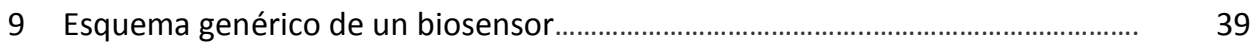

10 Esquema general de un biosensor óptico................................................................... 44

11 Esquema general de un transductor termométrico......................................................

12 Secuencia de una reacción de oxidación catalizada por una enzima oxidasa empleando oxígeno molecular como aceptador de electrones.............................. $\quad 47$

13 Esquema del Oximetro Mod. 20 Rank Brothers Ltd....................................................

14 Esquema del montaje de las membranas en el sensor de oxígeno........................... 89

15 Respuesta del sensor enzimático en el sistema con la enzima libre representada como oxígeno consumido en función del tiempo de reacción. $18.72 \mu \mathrm{M}$ de $\mathrm{Hx}$ en tampón fosfato $50 \mathrm{mM}$, pH 7.6 a $30^{\circ} \mathrm{C}$ y $0.0169 \mathrm{U}$ de xantina oxidasa.

16 Efecto del pH sobre la velocidad de reacción de la enzima xantina oxidasa determinado en el sensor enzimático con la enzima libre. $20 \mu \mathrm{L}$ de patrón de $\mathrm{Hx}(1 \mathrm{mM})$, en tampón fosfato sódico a diferentes $\mathrm{pH}, 0.0169 \mathrm{U}$ de $\mathrm{XO}$ a $30^{\circ} \mathrm{C}$

17 Efecto de la temperatura sobre la velocidad de reacción de la enzima xantina oxidasa determinada por HPLC con la enzima libre.

18 Efecto de la temperatura sobre la velocidad de reacción de la xantina oxidasa determinado en el sensor enzimático con la enzima libre. $20 \mu \mathrm{L}$ de patrón de $\mathrm{Hx}(1 \mathrm{mM})$, en tampón fosfato $\mathrm{pH}$ 7.6, $0.0169 \mathrm{U}$ de XO a diferentes temperaturas.. 
19 Curva de calibrado de hipoxantina en el sensor enzimático con la enzima libre. (Consumo de oxígeno ( $\mathrm{mg} \mathrm{O}_{2} / \mathrm{L}$ ) a 190 s frente a la concentración de $\mathrm{Hx}$ $(\mathrm{mM}))$...

20 Estabilidad de la xantina oxidasa en disolución en almacenamiento a $4{ }^{\circ} \mathrm{C}$.......

21 Curva de calibración de hipoxantina en el sensor enzimático con la enzima xantina oxidasa inmovilizada. (Consumo de oxígeno $\left(\mathrm{mg} \mathrm{O}_{2} / \mathrm{L} \bullet \mathrm{s}^{-1}\right.$ ) a $10 \mathrm{~s}$ frente a la concentración de $\mathrm{Hx}(\mathrm{mM}))$.

22 Estabilidad de operación de la membrana de xantina oxidasa (•) 0-30 inyecciones (o) 31-50 y ( $\mathbf{0}$ ) 51-70 inyecciones.

23 Estabilidad de la membrana de xantina oxidasa almacenada a $4{ }^{\circ} \mathrm{C}$. (•) Curva de calibración de hipoxantina durante dos meses ( $n=5$ membranas) ( 0 ) Curva de calibración de hipoxantina después de tres meses.

24 Evolución de la reacción de oxidación de hipoxantina en presencia de la enzima xantina oxidasa a $30^{\circ} \mathrm{C}$ y medida por HPLC.

25 Respuesta del sensor enzimático representado por el consumo de oxígeno acumulado $(\bullet)$ y el cambio de corriente $(\bullet)$ en función del tiempo de reacción en un patrón de histamina $(0.02 \mathrm{mg} / \mathrm{mL})$ en tampón fosfato 100 $\mathrm{mM}, \mathrm{pH} 7.4$ a $30^{\circ} \mathrm{C}$...

26 Evaluación de la selectividad de la diamina oxidasa (DAO) en el sensor enzimático con patrones de histamina (HI), putrescina (PU), cadaverina (CA), tiramina (TY), SD spermidina (SD), spermina (SM) a una concentración de $0.01 \mathrm{mg} / \mathrm{mL}$ en tampón fosfato $100 \mathrm{mM}, \mathrm{pH} 7.4$ a $30^{\circ} \mathrm{C}$.

27 Efecto del pH sobre la señal de respuesta de la enzima diamina oxidasa inmovilizada en el sensor sobre la histamina y putrescina a una concentración de $0.02 \mathrm{mg} / \mathrm{mL}$ utilizando un tampón fosfato $100 \mathrm{mM}, \mathrm{pH} 7.2$ a $30^{\circ} \mathrm{C}$

28 Respuesta del sensor enzimático de un extracto cárnico del músculo Semimembranosus de jamón (O días) enriquecido con patrón de histamina en ácido perclórico neutralizado a diferentes concentraciones a $30^{\circ} \mathrm{C}$.

29 Estabilidad de la diamina oxidasa inmovilizada en almacenamiento a $4{ }^{\circ} \mathrm{C}$ en tampón fosfato $100 \mathrm{mM}, \mathrm{pH} 7.2$

30 Cromatograma de IP-RP-HPLC correspondiente al análisis de muestras de carne de cerdo (Longissimus dorsi) a 5 (línea continúa) y 9 (línea quebrada) horas post-mortem..

31 Evolución de nucleótidos y sus derivados en el músculo Longissimus dorsi durante el proceso de maduración. 
32 Cromatogramas correspondiente al análisis de muestras de carne de cerdo (Longissimus dorsi) a 5 horas (A) y a 27 horas (B) post-mortem. Hipoxantina $(\mathrm{Hx})$, inosina (Ino), adenosín monofosfato (AMP), dinucleótido de nicotinamida adenina ( $N A D+$ ), inosina $5^{\prime}$ monofosfato (IMP), adenosín difosfato (ADP) y el adenosín trifosfato (ATP).

33 Cromatograma correspondiente a la separación de los patrones de los analitos estudiados junto con la creatinina $(\mathrm{Cn})$, ácido úrico $(\mathrm{AU})$, guanosina $(G)$, guanosín monofosfato (GMP), guanosín difosfato (GDP) y guanosín trifosfato (GTP)

34 Correlación entre el método HILIC y el método IP-PR-HPLC con respecto a las concentraciones de los analitos estudiados. La línea continua indica la correspondencia perfecta $(\mathrm{x}=\mathrm{y})$ y la línea quebrada las correlaciones obtenidos tras el análisis.

35 Cromatograma correspondiente al análisis de jamón curado de 11 meses por HILIC usando una columna ZIC-pHILIC (Sequant, 4.6 x 150 mm, $5 \mu \mathrm{m}$ ). Cn (creatinina), $\mathrm{Hx}+\mathrm{X}$ (hipoxantina+xantina), Ino (inopina), G (guanosina)

36 Evolución de las pérdidas de peso (nitrito $(\circ)$ nitrato $(\bullet)$ ) contenido de humedad (nitrito $(\triangle)$ nitrato $(\boldsymbol{\Delta})$ ) y temperatura (línea continua) durante el proceso de curado de los embutidos fermentados.

37 Población de estafilococos (nitrito $(\circ)$ nitrato $(\bullet)$ ), bacterias ácido lácticas (nitrito $(\triangle)$ nitrato $(\boldsymbol{\Delta})$ ) y evolución del pH ( $\square$ nitrito y $\boldsymbol{\square}$ nitrato) durante el proceso de curado de los embutidos fermentados.

38 Cromatograma de RP-HPLC correspondiente al análisis de una muestra de un embutido fermentado de 24 días de curado (línea continua) y la separación del patrón de xantina $(X)$ (línea quebrada). Creatinina $(\mathrm{Cn})$, hipoxantina $(\mathrm{Hx})$ y xantina $(\mathrm{X})$. La detección se realizó a $254 \mathrm{~nm}, 236 \mathrm{~nm}$ (creatinina) y $270 \mathrm{~nm}$ (xantina)

39 Evolución de nucleótidos y sus derivados durante el proceso de fermentación, maduración, secado y almacenamiento envasado al vacío de embutidos fabricados con nitrito (०) o nitrato (•)...

40 Evolución de la humedad en el músculo semimembranosus durante el proceso de curado de jamón con tres diversas formulaciones de la sal. 100 $\%$ del $\mathrm{NaCl}, \mathrm{Fl}(\bullet), 50 \% \mathrm{NaCl}$ y $50 \% \mathrm{KCl}$, FII (०) y $55 \% \mathrm{NaCl}, 25 \% \mathrm{KCl}, 15 \%$ $\mathrm{CaCl}_{2}$ y $5 \% \mathrm{MgCl}_{2}$, FIII 
41 Evolución del pH en el músculo semimembranosus durante el proceso de curado de jamón con tres diversas formulaciones de la sal. $100 \%$ del NaCl, $\mathrm{FI}$ $(\bullet), 50 \% \mathrm{NaCl}$ y $50 \% \mathrm{KCl}$, FII (०) y $55 \% \mathrm{NaCl}, 25 \% \mathrm{KCl}, 15 \% \mathrm{CaCl}_{2}$ y $5 \%$ $\mathrm{MgCl}_{2}$, FIII ( $\left.\mathbf{\Delta}\right)$

42 Evolución de nucleótidos y sus derivados en el músculo semimembranosus durante el proceso de curado de jamón usando tres diversas formulaciones de la sal. $100 \%$ del NaCl, FI (•), $50 \% \mathrm{NaCl}$ y $50 \% \mathrm{KCl}$, FII (०) y $55 \% \mathrm{NaCl}$, $25 \% \mathrm{KCl}, 15 \% \mathrm{CaCl}_{2}$ y $5 \% \mathrm{MgCl}_{2}$, FIII ( $\left.\mathbf{\nabla}\right)$...

43 Evolución del contenido de hipoxantina durante el proceso de maduración en carne de cerdo (Longissimus dorsi) obtenida por HPLC y el sensor enzimático en el sistema con la enzima libre e inmovilizada......

44 Correlación entre el contenido de hipoxantina obtenida por HPLC y el sensor enzimático en el sistema con la enzima libre e inmovilizada en muestras de carne de cerdo (Longissimus dorsi) a distintos tiempos post-mortem..

45 Evolución del contenido de hipoxantina durante el proceso de curado de un embutido fermentado obtenido por HPLC y el sensor enzimático en el sistema con la enzima libre e inmovilizada.

46 Correlación entre el contenido de hipoxantina obtenida por HPLC y el sensor enzimático en el sistema con la enzima inmovilizada durante el proceso de curado de un embutido fermentado. $(\bullet)$ señal directa del sensor $(H x+X)$ y $(0)$ señal ajusta da $(\mathrm{Hx})$.

47 Evolución del contenido de hipoxantina + xantina en el jamón curado (100 \% del $\mathrm{NaCl}, \mathrm{FI}(\bullet), 50 \% \mathrm{NaCl}$ y $50 \% \mathrm{KCl}$, FII (०)) durante el proceso de curado obtenido por HPLC y el sensor enzimático con la enzima inmovilizada. Formulación I (100\% del $\mathrm{NaCl}$ ) y formulación II (50\% NaCl y $50 \% \mathrm{KCl}$ ).

48 Correlación entre el contenido de hipoxantina + xantina durante el proceso de curado del jamón obtenida por HPLC y el sensor enzimático con la enzima inmovilizada en jamón curado. (•) $100 \% \mathrm{NaCl}$, Fl y (०) $50 \% \mathrm{NaCl}$ y $50 \% \mathrm{KCl}$, FII.

49 Evolución del contenido total de aminas biógenas durante el proceso de curado de un embutido fermentado fabricado con adición de nitrito (०) o nitrato $(\bullet)$...

50 Evolución de aminas biógenas en el embutido fermentado durante el proceso de curado en presencia de nitrito (०) o nitrato $(\bullet)$ 
51 Evolución de aminas biógenas en el músculo Semimembranosus durante el proceso de curado de jamón usando tres diversas formulaciones de sal. 100 $\%$ del $\mathrm{NaCl}, \mathrm{Fl}(-), 50 \% \mathrm{NaCl}$ y $50 \% \mathrm{KCl}$, FII (-) y $55 \% \mathrm{NaCl}, 25 \% \mathrm{KCl}, 15 \%$ $\mathrm{CaCl}_{2}$ y $5 \% \mathrm{MgCl}_{2}$, FIII (-).

52 Correlación entre el contenido de aminas biógenas obtenida por HPLC y el sensor enzimático DAO durante el proceso de curado de un embutido fermentado con nitrito $(\circ)$ o nitrato $(\bullet)$

53 Correlación entre el contenido de aminas biógenas totales en jamones curados de 11 meses obtenida por HPLC y el sensor enzimático DAO 



\section{Índice de Tablas}

Tablas

1 Clasificación de calidad de la carne de cerdo.

2 Categorías de calidad de carne en función del $\mathrm{pH}$, color y pérdidas por goteo. 8

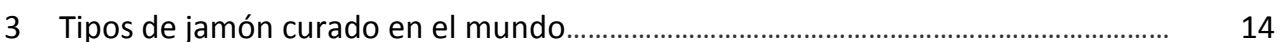

4 Clasificación de enzimas según el tipo de reacción que catalizan............................... 46

5 Sensores enzimáticos utilizados para evaluar los índices de frescura y/o maduración de pescado y carne.

6 Sensores enzimáticos utilizados para determinar hipoxantina en pescado y carne...

7 Sensores enzimáticos para la determinación de aminas biógenas en pescado y carne.

8 Selectividad de la enzima diamina oxidasa según su fuente de extracción

9 Ingredientes y aditivos usados en la fabricación del embutido fermentado curado.

10 Tratamientos de salado propuestos en el estudio de nucleótidos y sus derivados y aminas biógenas en jamón curado.

11 Condiciones de fase móvil y gradiente en el análisis de nucleótidos y sus derivados en carne fresca por IP-RP-HPLC

12 Condición de fase móvil y gradiente en el análisis de nucleótidos y sus derivados en carne fresca por HILIC.

13 Condiciones de fase móvil y gradiente en el análisis de nucleótidos y sus derivados en productos curados por RP-HPLC

14 Gradiente de fase móvil para el análisis de aminas biogénas por IP-RP-HPLC y derivatización post-columna

15 Resultados de validación del sensor enzimático en ambos sistemas, libre e inmovilizada.

16 Recuperación de la hipoxantina en muestras de lomo de cerdo (Longissimus dorsi) de 7 horas post-mortem en el sensor enzimático con la enzima inmovilizada.

17 Tiempos de retención y rectas de calibración obtenidos en el análisis de los patrones de hipoxantina $(\mathrm{Hx})$, inosina (Ino), adenosín monofosfato (AMP), dinucleótido de nicotinamida adenina (NAD+), inosina 5' monofosfato (IMP), adenosín difosfato (ADP) y adenosín trifosfato (ATP) 
18 Limite de detección (LD), repetibilidad y reproducibilidad calculados en muestras de lomo de cerdo de 5 horas post-mortem.

19 Recuperación de los analitos estudiados en muestras de lomo de cerdo de 5 horas post-mortem.

20 Concentración de peróxido de hidrógeno $\left(\mathrm{H}_{2} \mathrm{O}_{2}\right)$ en muestras de embutido fermentado curado, fabricados solo con nitrito sin la adición de especias y en un proceso de fermentación lenta. 
1. Introducción 



\section{Introducción}

El valor nutritivo de la carne de cerdo la señala como uno de los alimentos más completos y de gran importancia en la dieta humana, debido en gran parte a su aporte en proteínas de alto valor biológico (18-20 g proteína/100 g de carne) con un alto contenido en aminoácidos esenciales, lípidos (5-10 \%), carbohidratos (1\%) y minerales ( $1 \%)$. Se estima que $100 \mathrm{~g}$ de carne de cerdo cubren el $7 \%$ de las recomendaciones de ingesta diaria de hierro, $11 \%$ de potasio $6 \%$ de magnesio, $15 \%$ de zinc, además de ser una fuente importante de fósforo y vitamina B1 (Schweigert, 1994). Sin embargo, durante muchos años la carne de cerdo ha tenido una imagen equivocada (alimento "pesado", graso, con muy alto contenido en calorías y colesterol y asociado a enfermedades cardiovasculares y parásitos). Ante esta situación, los productores de carne y la industria cárnica en los últimos años han buscado la manera de obtener productos que minimicen los riesgos para el consumidor. En principio mediante la selección genética de los animales para producir más carne y menos grasa y/o modificando los procesos tecnológicos para mejorar las características nutritivas de los productos cárnicos a fin de mejorar su imagen y adaptarse a las necesidades del mercado (menos grasa, menos sal). Sin embargo, estas acciones han dado lugar a la aparición de defectos de calidad de la carne que afectarán a su aptitud para ser transformada en productos elaborados de calidad y a su conservación. Por todo ello, la detección rápida de este tipo de defectos es fundamental para determinar el destino de la carne y/o el control del proceso para definir la calidad del producto.

En España, la producción de carne de cerdo fue de 3,290.566 miles de toneladas en 2009 (Subdirección General de Estadística del Ministerio de Medio Ambiente y Medio Rural y Marino - MARM, 2009), del cual el 58 \% se destinó al consumo en fresco y el resto a la industria cárnica. Además, cuando se habla de carne porcina se distinguen dos tipos, la proveniente del cerdo blanco y la del cerdo ibérico. En el 
primero de ellos se obtiene un mayor rendimiento de canal y su carne resulta más magra, mientras que el cerdo ibérico es alimentado con bellotas y se destina principalmente a la industria de jamones y embutidos de calidad. La producción de embutidos curados en 2006 representó el 15.40 \% de la producción de elaborados cárnicos con una producción de 193 mil toneladas (Asociación de la Industria de la Carne de España - AICE, 2006), siendo el salchichón y el chorizo los productos más importantes. Mientras que la producción de jamón y paleta curados en los últimos 10 años se ha incrementado en un $42.20 \%$, lo que implica un consumo per cápita de $5 \mathrm{Kg}$ (Cruz, 2007). Debido a la importancia que tiene la carne de cerdo y sus productos derivados es importante conocer el proceso químico y bioquímico que tienen lugar durante su maduración y curado, por las implicaciones que tiene estos en el desarrollo de la calidad y seguridad.

\subsection{Calidad de la carne de cerdo y sus productos cárnicos.}

\subsubsection{Carne}

La carne según el Código alimentario Español se define como la parte comestible de los animales sanos sacrificados en condiciones higiénicas. En general, la composición de la carne se establece durante la vida del animal, mientras que su calidad se ve fuertemente afectada por factores ante-mortem y post-mortem. Aunque, la importancia de los diferentes aspectos cualitativos de la calidad de la carne difiere en función del segmento de la cadena cárnica en que se analice (producción, industrialización o comercialización).

Los atributos organolépticos son de gran importancia para el consumidor cuando se habla de carne fresca. El consumidor asocia como atributos de calidad de la carne el color (intensidad y coloración), la terneza, la jugosidad, la apariencia (grasa intramuscular, marmorización, exudación), el sabor y el aroma. Mientras que la industria centra más la atención en factores como pH, la capacidad de retención de 
agua (CRA), textura, estabilidad oxidativa y ausencia de sabores anómalos. Estos atributos están influenciadas por factores como la raza, la edad, la dieta, el manejo ante-mortem, los procesos de matanza y las prácticas de manejo post-mortem, las características intrínsecas del músculo y tejido conectivo, intensidad de proteolisis post-mortem en las células musculares y temperatura de cocción de la carne. En general, para definir la calidad de la carne y sus productos cárnicos se deben considerar las cualidades que constituyen el valor sensorial (calidad organoléptica) y nutritivo (calidad nutritiva) que junto con una serie de propiedades funcionales necesarias en el procesado y la fabricación de los productos cárnicos se incluye la calidad tecnológica y la calidad higiénico-sanitaria.

Desde el punto de vista bioquímico, la carne es el resultado de una serie de transformaciones y reacciones bioquímicas que tienen lugar en el músculo tras la muerte del animal, que definirán en gran parte la calidad de la carne. El proceso de conversión de músculo a carne se lleva a cabo en tres fases. La fase de demora del rigor o pre-rigor, comprende el tiempo, tras el sacrificio del animal en que las proteínas del músculo todavía no han sufrido cambios y el músculo aún es estirable y elástico; en cerdo varía de 15 minutos a 3 horas. La fase de rigor mortis que consta a su vez de dos etapas, el acortamiento de los sarcómeros (formación de enlaces entrecruzados entre filamentos finos y gruesos) y la rigidez (tensión continua de las fibras musculares). Así, en esta fase se forma el complejo proteico actina/miosina por agotamiento del ATP (adenosín trifosfato), se produce ácido láctico y el músculo se vuelve duro (Andujar et al., 2003). Finalmente en la fase de resolución o maduración, la extensibilidad de los músculos se recupera y la carne sufre un proceso de ablandamiento paulatino (Ouali y Sentandreu, 2002). Durante esta última etapa, la textura y el sabor mejoran sustancialmente después de un período de almacenamiento en temperatura de refrigeración (Vázquez y Vanaclocha, 2004). Aunque, dependiendo de la velocidad con que se lleve a cabo el metabolismo post- 
mortem, la carne de cerdo puede experimentar una gran variedad de cambios que definirán su calidad y esto tiene un gran impacto económico durante su venta como carne fresca o procesada. La temperatura a la cual se almacenan las canales de los animales recién sacrificados influye de manera definitiva en la velocidad con que ocurren dichas reacciones químicas. Sin embargo, el cambio de $\mathrm{pH}$ durante la transformación post-mortem del músculo a carne es posiblemente la causa más importante de la variación existente en la calidad, afectando sustancialmente al color y a la capacidad de retención de agua (CRA), atributos importantes desde el punto de vista tecnológico.

Por lo tanto en función de cómo sucede el proceso de maduración post-mortem, la carne se ha clasificado en cuatro grandes categorías de calidad (PSE, RSE, DFD, RFN) (Kauffman et al., 1992), como se describen en la tabla 1.

En este contexto, la detección rápida de la calidad de la carne es de suma importancia para la industria ya que esto permite optimizar las condiciones de procesamiento y distribución. Los músculos Longissimus dorsi y Semimembranosus son los más susceptibles a sufrir problemas de PSE y hace que éstos tengan una menor aceptación por su apariencia (Bravo-Sierra et al., 2005). Además, la carne PSE no resulta apropiada, por su escasa capacidad de retención de agua, para la elaboración de jamón cocido extra (separación de gran cantidad de gelatina) ni para elaborar jamón curado (elevadas pérdidas por secado, mayor absorción de sal, color pálido y escaso aroma) (Arnau et al., 1995). En cambio, la carne DFD es apropiada para productos del tipo emulsión cárnica (mortadelas y salchichas) y jamones cocidos, pero tampoco es aconsejable para fabricar jamón curado (especialmente peligroso en el caso de jamones con hueso) debido a su poca difusión de sal (Flores y Bernell, 1984), su fácil alteración microbiana ya que presentan texturas anómalas y precipitados de fosfato (Arnau et al., 1998). 
Tabla 1. Clasificación de calidad de la carne de cerdo.

Categoría de calidad/Características

PSE del inglés: Pale, soft and Exudative = Pálida, blanda y exudativa

Este tipo de carne se caracteriza porque sufre una caída rápida de $\mathrm{pH}$ después del sacrificio que combinada con una elevada temperatura provoca la desnaturalización de aproximadamente el $20 \%$ de las proteínas sarcoplasmáticas y miofibrilares, por consiguiente la disminución de la CRA. Esta condición hace a la carne altamente exudativa, le da una apariencia pálida al desnaturalizarse la mioglobina y una textura blanda, poco apetecible para los consumidores. La causa principal de la aparición de este tipo de carne se asocia con la susceptibilidad hereditaria del estrés porcino (PSS, por sus siglas en inglés Porcine Stress Syndrome), relacionado con la presencia del gen recesivo Halotano (asociado a hipertrofia muscular) y del gen Rendement Napole (RN), presentándose con mayor frecuencia en canales de animales mejorados genéticamente, para obtener un mayor rendimiento o desarrollo muscular. Aunque otros factores de manejo tanto del animal vivo (transporte, manejo violento, sacrificio con aturdimiento defectuoso) como de la canal inmediatamente después del sacrificio (enfriamiento deficiente) pueden influir en la incidencia y magnitud de esta condición.

DFD del inglés: Dark, firm and dry = Oscura, firme y seca

Carne típica de animales sometidos a situaciones de estrés moderado pero prolongado en el tiempo (transportes inadecuados en grandes distancias o ayunos largos), lo que hace que las reservas de glucógeno antes del sacrificio sean mínimas. El valor de $\mathrm{pH}$ se mantiene alto (> 6.0) debido a que el músculo no tiene suficiente sustrato (glucógeno) para utilizar en la glucólisis anaerobia y no se produce ácido láctico o se produce en muy poca cantidad. Presenta una alta retención de agua al estar el pH alejado del punto isoeléctrico de las proteínas musculares, la mioglobina se desnaturaliza en menor medida provocando una carne oscura y son muy sensibles a contaminación microbiana lo que hace difícil su conservación bajo refrigeración.

RFN del inglés: Red, firm and non-exudative = Roja, firme y no exudativa

Calidad de carne que se considera como la ideal, se trata de una carne roja, firme y normal. Esta característica la hacen adecuada tanto para el consumo en fresco como para la fabricación de productos cárnicos.

RSE del inglés: Reddish-pink, soft and exudative = Rojiza-rosácea, blanda y exudativa Esta carne se caracteriza por tener niveles de desnaturalización de proteína y pérdidas por goteo similares a las carnes PSE pero esta mantiene una coloración característica, debido posiblemente a un enfriamiento rápido de la canal después del sacrificio o por disposición genética. 
Actualmente, los métodos más usados para clasificar y predecir las diferentes calidades de la carne de cerdo en las plantas de sacrificio son la medición de $\mathrm{pH}$, el color y las pérdidas por goteo (drip loss) (Kauffmann et al., 1993; Warner et al., 1997; Flores et al., 1999). Aunque todos estos métodos poseen una justificación bioquímica ninguno de ellos por sí solo es suficiente para asegurar la correcta clasificación de las distintas calidades de la carne, por lo que se propone la combinación de varios de ellos como se muestran en la tabla 2.

Tabla 2. Categorías de calidad de carne en función del pH, color y pérdidas por goteo.

\begin{tabular}{cccc}
\hline Categoría & $\mathrm{pH}$ & Color (Brillo-L) & Pérdidas por goteo (\%) \\
\hline PSE & $\mathrm{pH}_{2 \mathrm{~h}}<5.8$ & $\mathrm{~L}>50$ & $>6 \%$ \\
$\mathrm{RSE}$ & $\mathrm{pH}_{2 \mathrm{~h}}<5.8$ & $44 \leq \mathrm{L} \geq 50$ & $>6 \%$ \\
$\mathrm{RFN}$ & $\mathrm{pH}_{2 \mathrm{~h}}>5.8$ & $44 \leq \mathrm{L} \leq 50$ & $<6 \%$ \\
& $\mathrm{pH}_{24 \mathrm{~h}}<6.0$ & $44<\mathrm{L}$ & $<3 \%$ \\
\hline DFD & $\mathrm{pH}_{24 \mathrm{~h}}>6.0$ &
\end{tabular}

Por otro lado, a fin de mejorar la predicción de la calidad de carne, nuevos ensayos bioquímicos han sido correlacionados con la calidad de la carne a fin de obtener una clasificación más adecuada. Flores et al., (2000) proponen el análisis de determinadas fracciones peptídicas a las 2 horas post-mortem para predecir y discriminar entre carnes exudativas y no exudativas. Mientras que Toldrá y Flores, (2000) sugieren el análisis de la actividad de las exo-proteasas (dipeptidil-peptidasa y amino-peptidasas) a las 2 y 24 horas post-mortem para predecir la calidad de la carne. Asimismo, Tsai et al., (1972); Honikel y Fischer, (1977) y Batlle et al., (2000), tras el sacrificio del animal, han detectado que el ATP se degrada más rápido en músculos PSE y más lento en DFD que en músculos normales, esta observación ha constituido la base para el desarrollo de distintos métodos de detección postmortem de la calidad de la carne (descritos en el apartado 1.2.4.). Recientemente, Castro-Giráldez et al., (2010), analizaron los cambios en las propiedades dieléctricas 
de la carne durante su maduración demostrando que esta técnica es útil para discriminar carne PSE y DFD a las 24 horas post-mortem.

\subsubsection{Embutidos curados fermentados.}

Los embutidos curados son productos tradicionales de inestimable valor gastronómico, que se originaron probablemente en la cuenca mediterránea (Lücke, 1994) y se definen como aquellos derivados, preparados a partir de carnes autorizadas, picadas o no, sometidos a procesos de curación, adicionados o no de despojos comestible y grasas de cerdo, productos vegetales, condimentos y especias e introducidos en tripas naturales o artificiales. Las características sensoriales (color, textura, sabor y aroma) del producto final vienen definidas por complejas transformaciones químicas y enzimáticas (musculares y microbianas) de los hidratos de carbono, proteínas y lípidos de la masa cárnica inicial, todas ellas moduladas por las condiciones físicas concretas en las que se lleva a cabo el proceso, así como por el efecto de las especias y de los agentes de curado. Los microorganismos desempeñan un papel decisivo en la fabricación de los embutidos fermentados, si la materia prima es de buena calidad higiénica y se mantienen las condiciones de maduración adecuadas se pueden fabricar embutidos tradicionales de excelente calidad. Sin embargo, la microbiota inicial de la masa cárnica (bacterias ácido lácticas (BAL) y Micrococcaceas) en general es muy heterogénea por lo que el uso de cultivos iniciadores o "starters" ha sido una práctica industrial muy utilizada para obtener una mayor homogeneidad, estabilidad y seguridad (Leistner, 1992).

El color es una propiedad sensorial muy importante en estos productos ya que influye en gran manera en su aceptación por parte de los consumidores. La presencia de nitrito, ascorbato o de microbiota con actividad nitratorreductasa (Micrococcaceae) favorecen la formación de nitrosomioglobina, otorgándole al embutido el color característico. El desarrollo de la textura se debe a la acumulación 
de ácido láctico, producto de la fermentación de carbohidratos. Como consecuencia de esto, el pH desciende hasta valores que se aproximan al punto isoeléctrico de las proteínas miofibrilares reduciendo su CRA con el consecuente incremento de la firmeza de la masa cárnica (Gimeno et al., 1999). Mientras que el aroma y sabor son resultado de una combinación equilibrada entre los compuestos volátiles (alcohol, acetonas, aldehídos y furanos) y no volátiles (aminoácidos, péptidos, azucares y nucleótidos) procedentes de las materias primas o generados a partir de las reacciones bioquímicas (proteolisis y lipólisis) que suceden durante la maduración (Flores et al., 1997; Toldrá, 1998; Fadda et al., 2002).

La amplia variedad de embutidos crudos curados fermentados que existen en el mercado radica en una tecnología de fabricación flexible que permite modificaciones siempre que se mantengan las reducciones adecuadas de $\mathrm{pH}$ y actividad de agua $\left(a_{w}\right)$. La figura 1 muestra el diagrama de flujo general del proceso de elaboración. Las diferencias y excepciones utilizadas en la industria se basan en la realización de un estufaje (período de incubación) más o menos intenso al que se somete la pasta cárnica recién embutida, provocando que la fermentación pueda ser más lenta o más rápida en función de la adición o no de azúcares, cultivos iniciadores y algunos otros aditivos (Róncales, 1994).

\subsubsection{Importancia del proceso de fabricación.}

Durante el proceso de fabricación, la carne y la grasa deben tener un grado de picado óptimo para evitar una consistencia muy blanda. La grasa aporta a los embutidos características importantes en el desarrollo de la calidad sensorial (jugosidad, untuosidad, suavidad, aroma y sabor); sin embargo, ésta debe agregarse lo más fresca posible, debido a la susceptibilidad que tiene para oxidarse, causando enranciamiento de los lípidos y, por tanto, de los olores, sabores y colores que lo caracterizan (Roncalés, 1994). 
Ingredientes $v$ aditivos

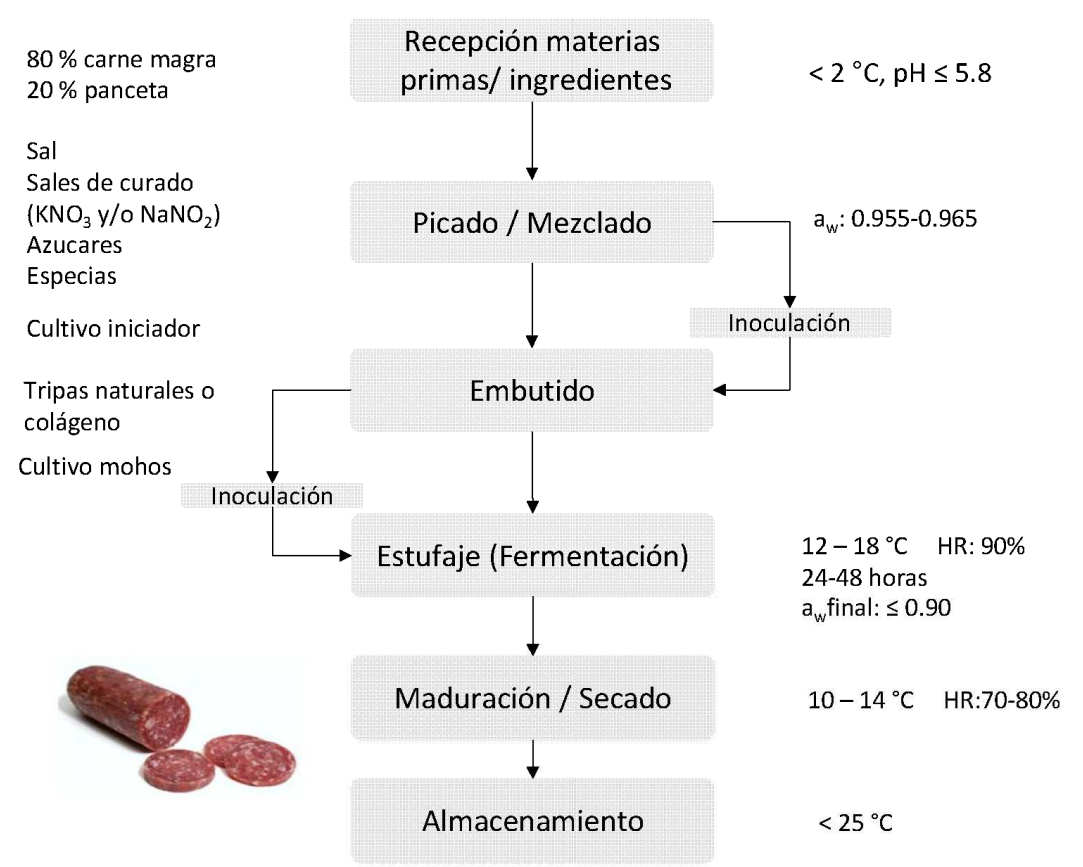

Figura 1. Diagrama de flujo de la elaboración de embutidos crudos curados fermentados.

La sal además de ser un ingrediente que mejora el sabor, proporciona cierto efecto antimicrobiano al provocar un descenso inmediato de la actividad de agua $\left(a_{w}=0.96\right)$ que restringe las condiciones de desarrollo de algunos microorganismos indeseables. Desde el punto de vista tecnológico ejerce un papel primordial en la ligazón de la pasta ya que favorece la solubilidad de las proteínas miofibrilares del músculo, y con ello el desarrollo de la textura (Lücke, 1994). Los azúcares fermentables (glucosa o sacarosa), como sustrato para el crecimiento microbiano (BAL), generan ácido láctico con el subsiguiente descenso de $\mathrm{pH}$. El compuesto activo de las sales de curación es el nitrito (añadido directamente o proveniente de la reducción de nitrato) actúa como agente antimicrobiano, inhibiendo la formación 
y el crecimiento de Clostridium botulinum, contribuye a la formación del color característico del curado (por formación del complejo nitrosomioglobina) y previene la oxidación de los componentes lipídicos al igual que el ascorbato. Las cantidades legalmente autorizadas en España son de 150 ppm para el nitrito y 330 ppm para el nitrato y las cantidades residuales no deben superar los 50 y 250 ppm, respectivamente (Real Decreto 142/2002 BOE 20/2/2002). Las especias se adicionan como potenciadores del sabor y por su actividad antioxidante (pimienta negra y jengibre) y antimicrobiana (ajo). El cultivo iniciador constituido principalmente por BAL (Lactobacillus, Leuconostoc y Pediococcus) crece rápidamente durante la fermentación $\left(10^{8}-10^{9}\right.$ u.f.c./g) y se mantiene prácticamente estables hasta el final del secado. Las BAL son agentes esenciales en la fermentación de la carne mejorando la calidad higiénica y sensorial del producto final. Su metabolismo fermentativo impide el deterioro y desarrollo de microbiota patógena por la acidificación del producto, contribuye a la estabilización del color y mejora la textura (Fadda et al., 2010). La presencia o la adición de cultivos iniciadores que contengan además bacterias pertenecientes a la familia Micrococcaceae (Kocuria varians, Staphylococcus carnosus y xylosus) es muy importante por su actividad nitrato reductasa que es la responsable de la reducción del nitrato a nitrito, contribuye a la reducción del nitrito residual y poseen actividad catalasa para la protección del color y prevención de la rancidez. Los mohos (Penicillium) que se añaden sobre la superficie de la tripa de los embutidos metabolizan los ácidos orgánicos y ejercen desaminación oxidativa de los aminoácidos produciendo amonio que eleva el pH de los embutidos y potencia el aroma y sabor típicos (Marchesini et al., 1992).

\subsubsection{Jamón curado}

El jamón curado, definido por el Código Alimentario Español como un producto cárnico elaborado mediante la salazón en seco con posterior desecación y maduración, de la extremidad posterior del cerdo, seccionada por la sínfisis-pubiana, 
que conserva todos sus huesos, músculos, tejido adiposo de infiltración, vasos y nervios, así como una porción variable de la piel y el tejido adiposo de revestimiento, constituye uno de los productos tradicionales más importantes de la carne de cerdo, típicos de la gastronomía española. Debido a la demanda de este producto en los últimos años, la elaboración del jamón curado tradicional ha pasado a ser mayoritariamente industrial, introduciendo la mecanización del proceso y el uso de secaderos con control de temperatura y humedad relativa. De este modo, se puede producir jamón curado en cualquier época del año y en cualquier zona geográfica. Así, numerosas variedades de jamón curado se han desarrollado a lo largo del mundo (Tabla 3). España es el país con el mayor reconocimiento gastronómico en este producto, con la presencia de dos tipos de jamón curado, cuya clasificación la marca la raza de los cerdos de los que proviene: jamón procedente de cerdo ibérico y jamón procede de cerdo blanco. Al primero de ellos se le considera como el jamón curado de máxima calidad, debido a que presenta una excelente calidad sensorial, aunque más del 80 \% de la producción de jamón se elabora de jamones y paletas de cerdo blanco.

El jamón presenta un color rojizo que se debe a la interacción química del óxido nítrico (formado por la reducción del nitrito) y mioglobina para formar nitrosomioglobina, compuesto estable al calor pero muy lábil a la oxidacion. La textura dependerá de varios factores tales como el grado de secado durante el proceso, del alcance de la proteolisis, y del contenido en grasa y tejido conectivo (Toldrá, 2006b). 
Tabla 3. Tipos de jamón curado en el mundo.

\begin{tabular}{|c|c|c|c|}
\hline País & Jamón curado & $\begin{array}{c}\text { Duración de } \\
\text { proceso (meses) }\end{array}$ & Comentarios \\
\hline$\overline{\text { España }}$ & $\begin{array}{l}\text { Jamón Ibérico (cerdo Ibérico) } \\
\text { De cebo } \\
\text { De cebo campo } \\
\text { De recebo } \\
\text { De bellota }\end{array}$ & $24-36$ & $\begin{array}{l}\text { Denominación de origen (DOP) }{ }^{1} \text { : Jamón de Huelva, Los } \\
\text { Pedroches, Jamón de Guijuelo y Dehesa de Extremadura. } \\
\text { Denominaciones comerciales: Jamón de Pata Negra, Jamón } \\
\text { de Jabugo o Jamón 5J }\end{array}$ \\
\hline & $\begin{array}{l}\text { Jamón Serrano (Cerdo Blanco) } \\
\text { Bodega } \\
\text { Reserva } \\
\text { Gran reserva }\end{array}$ & $\begin{array}{c}9-18 \\
9-12 \\
15 \\
\text { mas de } 15\end{array}$ & $\begin{array}{l}\text { DOP: Jamón de Teruel. } \\
\text { Indicacion de Origen Protegida (IGP): Jamón de Trevélez. } \\
\text { Especialidad Tradicional Garantizada (ETG) } \\
\text { murciano o Jamón de Chato } \\
\text { ón de cerdo Duroc }\end{array}$ \\
\hline Portugal & $\begin{array}{l}\text { Jamón Chaves } \\
\text { Jamón Ibérico alentejano }\end{array}$ & & $\begin{array}{l}\text { Jamón de Pata Blanca } \\
\text { Jamón Ibérico puro DOP. Barrancos. Jamón de Pata Negra }\end{array}$ \\
\hline Italia & $\begin{array}{l}\text { Jamón de Parma } \\
\text { Jamón San Daniele } \\
\text { Jamón de Carpegna } \\
\text { Jamón de Toscana } \\
\text { Jamón de Venecia }\end{array}$ & $\begin{array}{c}12-18 \\
9-18\end{array}$ & $\begin{array}{l}\text { DOP: Jamón de Parma } \\
\text { DOP: Prosciutto di San Daniele }\end{array}$ \\
\hline Francia & $\begin{array}{l}\text { Jamón de Bayonne } \\
\text { Jamón de Corsica }\end{array}$ & $\begin{array}{c}9-12 \\
24\end{array}$ & \\
\hline Noruega & $\begin{array}{l}\text { Jamón Fenalar } \\
\text { Jamón Spekeskinke }\end{array}$ & & \\
\hline Alemania & $\begin{array}{l}\text { Jamón Schinken } \\
\text { Jamón Westphalian } \\
\text { Jamón Katenschinken }\end{array}$ & $\begin{array}{l}3-5 \\
3-5\end{array}$ & Jamón ahumado \\
\hline USA & Country-style & $3-9$ & Jamón ahumado \\
\hline China & $\begin{array}{l}\text { Ching Hua } \\
\text { Yunnan }\end{array}$ & $\begin{array}{l}3-6 \\
3-6\end{array}$ & Jamón ahumado \\
\hline
\end{tabular}

\subsubsection{Importancia del proceso de fabricación.}

La calidad del jamón curado está condicionada en gran medida por la materia prima utilizada para su producción, la cual es afectada directamente por factores ante-mortem (raza, edad, tipo de alimentación, condiciones previas al sacrificio, cantidad de grasa, capacidad proteolítica, etc), post-mortem (refrigeración, congelación, etc) y del proceso tecnológico aplicado. El pH es un parámetro importante para seleccionar el jamón adecuado al proceso (eliminado aquellos con un pH mayor de 6.20). El uso de jamones congelados facilita la disolución de la sal en la superficie, la migración hacia el interior y probablemente el transporte de agua 
hacia el exterior, aunque también facilita la cristalización de tirosina durante la maduración, dando lugar a un mayor numero de pintas blancas (Arnau et al., 1994). En particular, la cantidad de grasa y el peso del jamón definirán el tiempo de procesado. La presencia de grasa infiltrada y una cierta cantidad de grasa superficial frena el proceso de secado, confiriendo una sensación untuosa en la boca y un sabor muy apreciado (Arnau, 1998).

El proceso de fabricación del jamón curado (Figura 2) comprende básicamente cuatro etapas importantes: pre-salado, salado, post-salado y secado/maduración (que puede incluir una fase de estufaje y una de bodega), que tras el curado y como consecuencia de múltiples reacciones químicas y bioquímicas reguladas por la temperatura, humedad y tiempo de curado, facilitan el desarrollo del color, textura y sabor característicos (Toldrá, 1998). El pre-salado consiste en la adición de una mezcla de sal con las sales de curado (nitrito y nitrato) y en algunas ocasiones ascorbato y azúcar mediante masajeado para facilitar la penetración de esa mezcla y se lleve a cabo la nitrificación. El salado debe realizarse cuando el jamón alcanza una temperatura de $1-3{ }^{\circ} \mathrm{C}$, ya que a esta temperatura se logra inhibir el desarrollo de microorganismos anaerobios alterantes y potencialmente patógenos (Clostridium botulinum) y, se produce la paulatina deshidratación del jamón (Toldrá, 2002). La sal contribuye a la disminución de la actividad de agua, a la solubilización parcial de las proteínas miofibrilares, y al sabor característico. Entre los procedimientos más utilizados en España de salado por vía seca se distinguen el apilado de los jamones (máximo 6) recubiertos de sal y la aplicación de una cantidad fija de sal por $\mathrm{Kg}$. de jamón y el salado en cubos o contenedores que son procesos más higiénicos. Además se ha propuesto la impregnación de sal al vacío como método de salado (Barat et al., 1998). La distribución homogénea de la sal absorbida en la etapa de salado se desarrolla en una etapa de post-salado al tiempo que se inicia el proceso de deshidratación del producto. Finalmente, en la etapa de secado-maduración se 
logra la estabilización del producto, alcanzando una pérdida de peso alrededor del $32-36 \%$ y la intensidad de la proteolisis y lipólisis que condicionan el aroma se incrementan (Toldrá, 1998 y 2002).

\section{Ingredientes $v$ aditivos}

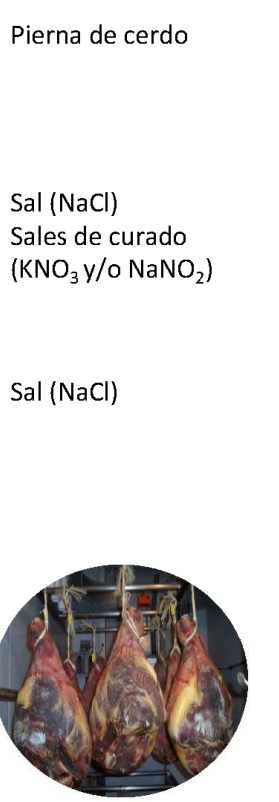

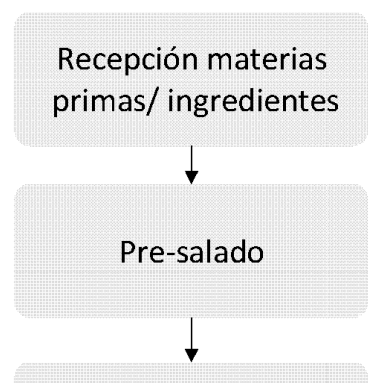
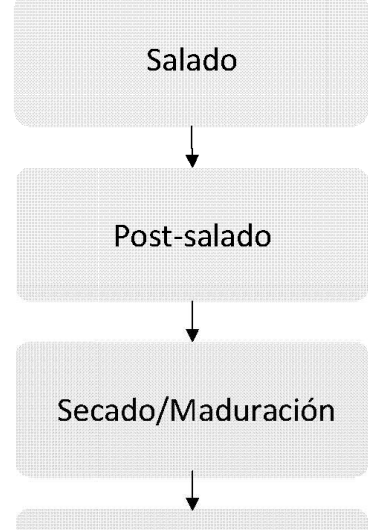

Almacenamiento

\section{Condiciones de proceso}

$\mathrm{pH}<6.2$

Eliminación de la sangre residual

$<4{ }^{\circ} \mathrm{C}$

HR: $>90 \%$

1.1 día/Kg de jamón

$<4{ }^{\circ} \mathrm{C}$

HR: $75-85 \%$

40-60 días

$14-20^{\circ} \mathrm{C}$

HR: $75-80 \%$

6 meses y 2 años

Figura 2. Diagrama de flujo de la elaboración del jamón curado.

Actualmente la tendencia por parte de los consumidores es demandar productos elaborados bajos en sal, debido a que la ingesta excesiva de sal (más de 6 g/día/persona) está estrechamente asociada con la hipertensión y, en consecuencia un mayor riesgo de padecer enfermedades cardiovasculares (Ruusunen y Puolane, 2005). Algunos estudios encaminados a reducir el contenido en sal (Andrés et al., 
2004) y/o el tiempo de salado (Arnau et al., 1997) o a substituir el $\mathrm{NaCl}$ por otras sales (Blesa et al., 2008) han sido desarrollados en este tipo de productos. Sin embargo, la principal dificultad surge porque estas acciones pueden alterar la bioquímica de proceso, la cual es muy importante para el correcto desarrollo de la textura y el sabor.

\subsection{Principales cambios bioquímicos en la carne y productos cárnicos curados durante la maduración.}

Durante la maduración de la carne y los productos cárnicos curados ocurren una serie de cambios bioquímicos que son esenciales para el desarrollo de la calidad ya que gran variedad de enzimas permanecen activas en el músculo post-mortem e intervienen en múltiples vías metabólicas. Las más importantes están relacionados con el metabolismo de los hidratos de carbono (enzimas glucolíticas) en el proceso de la glucólisis, con la degradación de las proteínas (endopeptidasas y exopeptidasas) en el proceso de proteolisis, con la hidrólisis de triglicéridos y fosfolípidos (lipasas y fosfolipasas) en el proceso de lipólisis y finalmente con la transformación de los nucleótidos (Toldrá, 2006a). Todas las reacciones ocurren de forma simultánea con mayor o menor preponderancia según las condiciones concretas de cada proceso.

\subsubsection{Glucólisis}

El ATP es la fuente principal de energía para el proceso de contracción y relajación en el músculo vivo, tras el sacrificio el mecanismo aerobio de obtención de ATP cesa, por lo que es necesario obtenerla a partir del metabolismo celular vía glucólisis anaerobia, fosforilación oxidativa a partir de la degradación irreversible de la creatina fosfato (CP) o de la condensación de dos moléculas de ADP (adenosín difosfato) (Toldrá, 2006a). La glucólisis es la ruta principal en el metabolismo de la glucosa o del glucógeno para sintetizar el ATP en condiciones aerobias o anaerobias, 
como se muestra en la figura 3. En condiciones aerobias este proceso consiste en una serie de diez reacciones enzimáticas catabólicas o degradativas en presencia de enzimas endógenas (glucohidrolasas), que convierten la glucosa en ácido pirúvico (piruvato) y se lleve acabo la respiración celular. Al momento de la muerte del animal, el mayor cambio que experimenta el músculo tiene que ver con esa síntesis energética. El aporte de oxígeno derivado de la circulación sanguínea al tejido muscular se interrumpe, la respiración celular se paraliza y surge la síntesis anaerobia de energía con un rendimiento mucho menor en la generación de ATP. El músculo anaerobio no puede mantener su nivel normal de ATP y la glucólisis postmortem provoca la reducción del ácido pirúvico en presencia de la enzima lactato deshidrogenasa a ácido láctico, con la consecuente disminución de $\mathrm{pH}$ en el músculo. El descenso de $\mathrm{pH}$ hace que las proteínas miofibrilares se aproximen a sus puntos isoeléctricos y se desnaturalicen. La desnaturalización va acompañada de una reducida capacidad de retención de agua de las proteínas (CRA), fenómenos causantes de la exudación y por ende de la aparición de las diversas calidades de carne, como ya se ha descrito en el apartado 1.1.1.

En los productos fermentados se dan además reacciones glucolíticas de origen exógeno. Los hidratos de carbono adicionados sirven de sustrato para el crecimiento de los microorganismos presentes o los adicionados en los cultivos iniciadores y su fermentación produce acido láctico que resulta también en una caída de pH. La intensidad de acidificación dependerá en gran parte del tipo de BAL presentes en el cultivo iniciador, la cantidad de carbohidratos añadidos y de la temperatura de fermentación (Toldrá, 2008). 


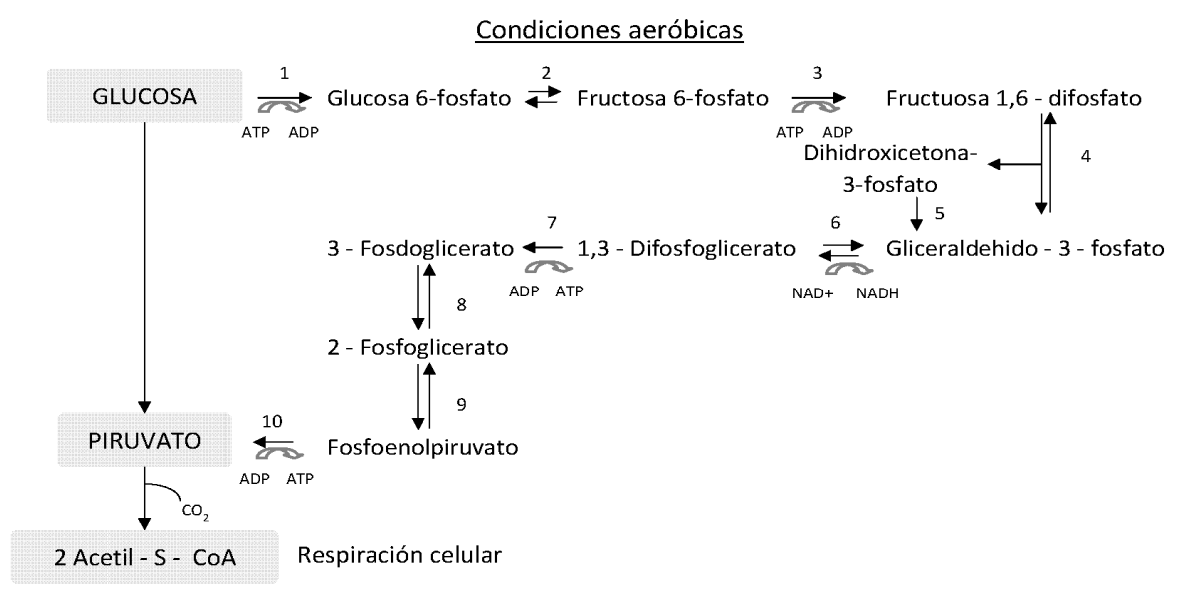

Condiciones aneróbicas

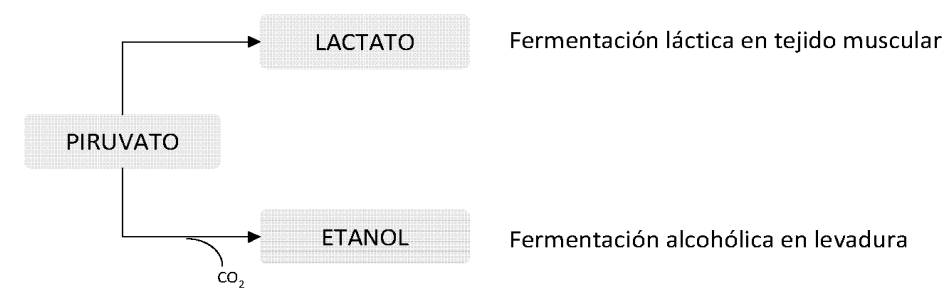

Figura 3. Proceso de glucólisis en condiciones aerobias y anaerobias.

1. Hexoquinasa o glucoquinasa, 2. Fosfoglucoisomerasa, 3. Fosfofructoquinasa, 4. Fructosa1,6-bis-fosfato aldolasa, 5. Triosa-fosfato isomerasa, 6. Gliceraldehído-3-fosfato deshidrogenasa, 7. Fosfoglicerato quinasa, 8. Fosfoglicerato mutasa, 9. Enolasa, 10. Piruvato quinasa, 11. Lactato deshidrogenasa

\subsubsection{Proteolisis}

La proteolisis es un proceso bastante complejo en el cual participan dos grandes grupos de enzimas; la proteasas de tipo endopeptidasas ( $\mu$-calpaína (I), m-calpaína (II), catepsinas B, D, H y L y proteosoma) y las exopeptidasas (Tri-peptidilpeptidasas I y II, dipeptidilpeptidasas I, II, III y IV, carboxipeptidasas y alanil-, arginil-, metionil-, leucil-, y piroglutamil- aminopeptidasas) (Toldrá y Flores, 1998). Las endopeptidasas son las enzimas responsables de la degradación de las proteínas miofibrilares principalmente y en menor grado de las sarcoplásmicas, generando fragmentos 
proteicos y peptídicos que van a servir de sustrato a las exopeptidasas (Toldrá y Flores, 1998; Toldrá, 2006b), las cuales hidrolizan las cadenas peptídicas a partir de sus extremos terminales. Las peptidasas son las responsables de la generación de di y tripéptidos, mientras que las aminopeptidasas y carboxipeptidasas liberan aminoácidos libres (Figura 4). Estos compuestos son la base para el desarrollo de nuevas reacciones químicas (reacción de Maillard y/o degradación de Strecker), importantes en el desarrollo del sabor y aroma, como se describirá más adelante.



Di y Tripéptidos

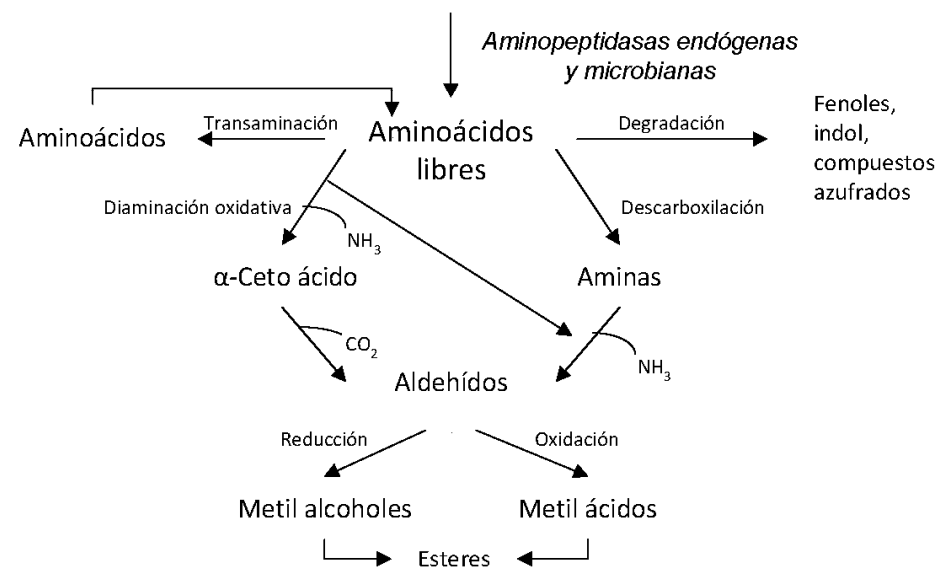

Figura 4. Esquema general de la proteolisis y las reacciones de transformación de los aminoácidos libres. (Modificado de Toldrá, 2002). 
Carne

El ablandamiento o terneza de la carne durante la maduración es debida principalmente a la degradación de las proteínas que constituyen la estructura muscular. Esta ruptura proteica es debida a la acción sinérgica de las peptidasas endógenas que incluyen a las calpaínas, catepsinas, proteosoma y las caspasas (Toldrá, 1998; Santandreu et al., 2002, Toldrá y Aristoy, 2010), aunque la actividad de estas enzimas puede variar dependiendo de la genética, la edad de los animales, el tipo de músculo y de las condiciones de procesamiento de la carne (Toldrá, 1998). Algunos autores han estudiado ampliamente los cambios post-mortem de las proteínas musculares con el fin de mejorar la calidad de la carne (Maltin et al., 2003; Koohmaraie y Geesink., 2006; te Pas et al., 2009; Kemp et al., 2010). Las calpaínas han sido consideradas las responsables principales de la proteolisis de la carne en los primeros días post-mortem al degradar las proteínas de la línea Z. Su activación inicia como respuesta a la liberación de iones $\mathrm{Ca}^{2+}$ (al descender el pH durante el período post-mortem) a bajas concentraciones para las calpaínas I (50 a $70 \mu \mathrm{M})$, mientras que altas concentraciones $(5 \mathrm{mM})$ son requeridas para activar la calpaína II. Sin embargo, ambas enzimas se ven reguladas por una tercera proteína denominada calpastatina. Existen evidencias que la relación calpastatina/calpaína puede ser un buen indicador para pronosticar la dureza o blandura de la carne (Koohmaraie, 1994). Mientras que las catepsinas (B, D, H y L), que se encuentra en los lisosomas, se activan al descender el $\mathrm{pH}$ durante el período post-mortem y han sido relacionadas con la degradación autolítica de la estructura miofibrilar al ser capaces de hidrolizar miosina, actina, nebulina, titina, tropomiosina, troponina T y colágeno.

\section{Productos cárnicos curados (embutido fermentado y jamón curado)}

Las reacciones proteolíticas que ocurren durante el proceso de curado de embutidos fermentados y jamón curado han sido estudiadas extensamente (Flores et al., 1997; Toldrá y Flores, 1998; Toldrá, 2006b; Toldrá, 2008). La proteolisis es la 
transformación con mayor impacto en estos productos debido a que afecta directamente la percepción sensorial de los mismos, al producir un incremento en la concentración de péptidos y aminoácidos, que están estrechamente relacionados con el sabor e indirectamente con el aroma (Nishimura, 2002), además de tener un impacto sobre la textura al ser responsable de la hidrólisis de las proteínas miofibrilares (Toldrá y Flores 1998). Según qué aminoácido, base o péptidos predominen en el producto, éste puede ser más dulce (glicina, alanina, serina, treonina, lisina, prolina, hidroxiprolina, glucosa, fructosa, ribosa), salado (glutamanto y aspartato), amargo (creatina, creatinina, hipoxantina, anserina, carnosina, fenilalanina, arginina, metionina, histidina, valina, leucina, isoleucina, triptófano y tirosina), ácido (ácido aspártico, glutámico, succínico, láctico, etc) o umami (glutamato, IMP y péptidos) (Toldrá, 1994).

En los embutidos fermentados, estos cambios se deben tanto a la actividad de las enzimas endógenas como a la de las enzimas procedentes de microorganismos exógenos nativos o adicionados (cultivos iniciadores) (Sanz et al., 1999 y 2002; Toldrá, 2008). Aunque la hidrólisis primaria de la proteínas a polipéptidos es realizada mayoritariamente por las enzimas musculares endógenas. Las BAL y los micrococcus, tienen cierta actividad proteolítica y pueden contribuir a la degradación de las proteínas musculares, en mayor medida sobre las proteínas miofibrilares. Incluso, se ha señalado que la enzimas intracelulares (amino, di- y tripeptidasas) de Lactobacillus son las responsables de la generación de pequeños péptidos y aminoácidos que contribuyen al proceso, ya sea como potenciadores del sabor o como precursores de otros compuestos aromáticos durante la maduración de los embutidos crudos curados (Sanz et al., 2002). Los agentes de curado y las condiciones de proceso (temperatura, $\mathrm{pH}$, duración del proceso) en estos productos actúan como reguladores de la actividad de la exopeptidasas (Sanz et al., 2002). El $\mathrm{pH}$ controla en mayor grado la hidrólisis, los embutidos fermentados con pH más 
ácidos (4.60) se caracterizan por una alta concentración de péptidos y poca producción de amoniaco, debido en gran medida a la catepsina $\mathrm{D}$, que es activa a $\mathrm{pH}$ ácidos. La sal (2-3\%) inhibe parcialmente a las catepsinas pero activa a las calpaínas y aminopeptidasa B. Durante el secado y maduración se incrementa el contenido de los péptidos de bajo peso molecular y los aminoácidos libres (Toldrá y Flores, 1998; Toldrá et al., 2000) que mediante reacciones químicas y/o enzimáticas como la descarboxilación, desaminación, deaminación y transaminación se generan compuestos volátiles y no volátiles de gran importancia en el desarrollo del aroma y sabor de estos productos (Figura 4). Además, en presencia de bacterias de deterioro inducirán en gran medida la descarboxilación de los aminoácidos, produciendo aminas biógenas (ver apartado 1.2.5.).

En el jamón curado, la proteolisis es uno de los grupos de reacciones bioquímicas más importantes en la generación del aroma y sabor durante el procesado. El tiempo de maduración y procesado es mucho mas largo (12-24 meses) lo que hace que la rotura de la estructura miofibrilar sea mucho más intensa y completa dando lugar a una gran cantidad de aminoácidos libres y péptidos pequeños (Aristoy y Toldrá, 1995). Las calpaínas están activas tan solo en las primeras semanas (etapa de post-salado) mientras que las catepsinas $(B, H$ y $L$ ) son muy estables y se mantienen hasta 15 meses a lo largo de todo el proceso (Toldrá et al., 1993). El descenso de la actividad de agua $\left(a_{w}<0.84\right)$ que se produce durante el secado del jamón, provoca una disminución de la actividad de las catepsinas (Toldrá et al., 1992). Así, la mayor parte de los aminoácidos libres que se generan son resultado de la acción de las aminopeptidasas (Toldrá et al., 1997), aunque estas se ven inhibidas por la acumulación de los aminoácidos libres al final del proceso (Flores et al., 1998). Sin embargo, la acción de estas enzimas dependerá en gran medida de la temperatura y del tiempo de maduración, el grado de secado, la cantidad de sal y el pH. 


\subsubsection{Lipólisis}

La lipólisis es un conjunto de reacciones enzimáticas que suponen la hidrólisis de los lípidos musculares o del tejido adiposo, separando los ácidos grasos de las moléculas de glicerol de los triglicéridos (lipasas) e hidrolizando los enlaces éster de los fosfolípidos (fosfolipasas) (Toldrá, 2006a). El resultado final de la acción de ambos grupos de enzimas consiste en la generación de numerosos ácidos grasos libres (Figura 5), tanto saturados como mono y poliinsaturados, que posteriormente se relacionan con procesos de oxidación química o enzimática, contribuyendo al aroma del producto (Estévez et al., 2009).

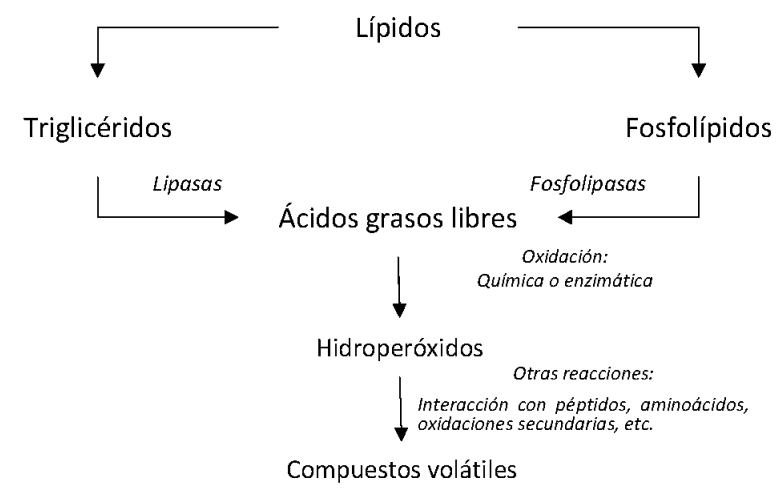

Figura 5. Esquema general de la lipólisis (Toldrá, 2002).

\section{Carne}

En el músculo las enzimas más importantes son la lipasa ácida lisosomal, que hidroliza los tri-, di- y monoglicéridos y tiene un pH óptimo comprendido entre 4.5 y 5.0 y las fosfolipasas A1 y A2 que catalizan la hidrólisis de los fosfolípidos. Otras enzimas lipolíticas musculares de menor importancia son la lipasa neutra y la lipasa monoglicérida, responsables de la generación de ácidos. Las enzimas principales del tejido adiposo son la lipasa sensible a hormona, la lipasa lipoproteica, la esterasa ácida y la esterasa neutra (Toldrá y Flores, 1998). 


\section{Embutido fermentado curado}

En la elaboración de embutidos curados fermentados donde la grasa es uno de los componentes mayoritarios se observa una intensa lipólisis (Navarro et al., 1997) que puede deberse a la actividad enzimática endógena (destacando la lipasa ácida lisosomal) o aquella de origen bacteriano (Micrococcaceae, hongos y levaduras). Durante la lipólisis se generan ácidos grasos libres que influyen de manera directa con el sabor (ligera acidez) e indirectamente con el aroma a través de procesos de oxidación que conduce a la generación de sustancias tales como aldehídos, cetonas, alcoholes, ésteres y alcanos (Marco et al., 2006; Toldrá, 2008). Aunque estas enzimas muestran buena estabilidad durante los procesos de secado (Toldrá, 2006b), su estabilidad dependerá del pH, contenido de sal, temperatura de maduración y actividad de agua (Toldrá, 2008).

\section{Jamón curado}

En el jamón curado la hidrólisis enzimática de los lípidos ocurre a dos niveles: a) sobre el tejido adiposo afectando principalmente a los triglicéridos generando di y monoglicéridos, liberando una gran cantidad de ácidos grasos libres (Motilva et al., 1993) y, b) sobre la grasa intramuscular, actuando sobre los lípidos que se encuentran en el interior del músculo, los cuales constan de triglicéridos y fosfolípidos, aunque a este nivel la hidrólisis ocurre principalmente sobre estos últimos. Así, las fosfolipasas actúan sobre los fosfolípidos rompiendo sus enlaces para generar ácidos grasos libres (Motilva et al., 1993), los cuales son posteriormente oxidados y pueden considerarse como precursores importantes de un buen aroma, siempre y cuando no se supere la intensidad que la haga negativa por predominar los olores y sabores rancios. Durante la maduración del jamón las lipasas musculares (ácida lisosomal y neutral) demuestran una gran estabilidad permaneciendo activas a los 15 meses de proceso. (Toldrá y Flores, 1998). 


\subsubsection{Transformación de nucleótidos y nucleósidos}

Los nucleósidos son las moléculas resultantes de la unión de una base nitrogenada (purina o pirimidina) y una molécula de azúcar (ribosa o desoxirribosa), mediante un enlace $\mathrm{N}$-glucosídico. Las bases pirimídicas incluyen al uracilo, citosina, y timina, mientras que las base púricas incluyen a la adenina, guanina, hipoxantina y xantina. Los nucleótidos son los esteres fosfóricos de los nucleósidos al formase por la unión de estos con una molécula de ácido fosfórico en forma de ión fosfato $\left(\mathrm{PO}_{4}{ }^{3}\right)$. EI ATP (adenosín trifosfato), fuente principal de energía de la célula utilizada en una gran variedad de reacciones metabólicas, es el nucleótido mayoritario en músculo vivo y se forma por la unión de una base nitrogenada de adenina con una ribosa y tres fosfatos (Figura 6). Tras la muerte del animal, la concentración de ATP se reduce y ésta es la principal causa de la instauración del rigor mortis en la carne (Greaser, 1986).

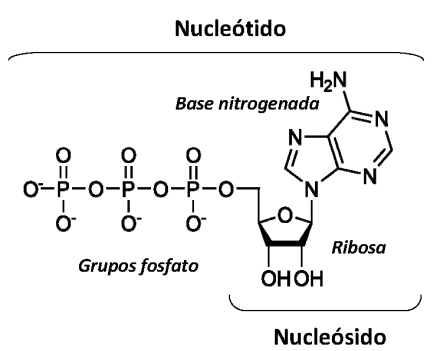

Figura 6. Estructura química de los nucleósidos y nucleótidos (Modificado de Aristoy et al., 2010)

La degradación del ATP ocurre rápidamente, por acción de enzimas endógenas del músculo, como se observa en la figura 7 , dando lugar a la acumulación de ADP (adenosín difosfato) y AMP (adenosín monofosfato). El ADP, resultado de la actividad ATPasa, es refosforilado a ATP a partir de la fosfocreatina (CP) por la enzima creatina-quinasa o por glucólisis anaerobia degradando al glucógeno. Sin embargo, con el tiempo post-mortem se van agotando estas reservas y el ciclo de 
contracción-relajación se detiene hasta llegar a un estado de contracción sostenida por la formación irreversible del complejo actiomiosina. Posteriormente el AMP es desaminado a IMP (inosín 5'monofosfato), el cual se descompone en inosina (INO) y posteriormente a hipoxantina $(\mathrm{Hx})$ (Burns y Ke, 1985). La oxidación de la Hx a xantina $(\mathrm{X})$ y ácido úrico $(\mathrm{AU})$ es un proceso lento y participan tanto enzimas autolíticas como microbianas (Surette et al., 1988). Paralelo a este proceso, aunque en menor medida, ocurre la degradación de la guanosina monofosfato (GMP) a guanosina (GUA) y guanina (G), la cual es desaminada y contribuye también a la formación de $X$ y AU (Urich, 1990).

El análisis de estos compuestos ha sido propuesto como método rápido y simple para determinar la frescura y calidad de la carne durante los primeros momentos post-mortem. Incluso, se han desarrollado métodos rápidos para la evaluación postmortem de la carne. Uno de los métodos, hace uso del denominado valor R, que consiste en medir la relación entre las absorbancias a 250 y $260 \mathrm{~nm}$, para distinguir entre PSE y DFD, solo necesita entre 3 y 4 minutos para su determinación, que por la rapidez de medida se ha sugerido como método interesante para el control de calidad en el matadero (Honikel y Fischer, 1977). Por su parte, Batlle et al., (2000 y 2001) propusieron la variación del valor $R$ a valor $R$ ', calculando la relación entre concentraciones de los compuestos derivados de la inosina y los de la adenosina. Este valor demostró ser útil para discriminar entre carnes PSE, normales y DFD a las 2 horas post-mortem e incluso a las 8 horas, pero deja de ser útil a las 24 horas. De igual manera se propuso la utilización de la relación IMP/ATP para discriminar carnes PSE tan solo a las 2 horas post-mortem. 


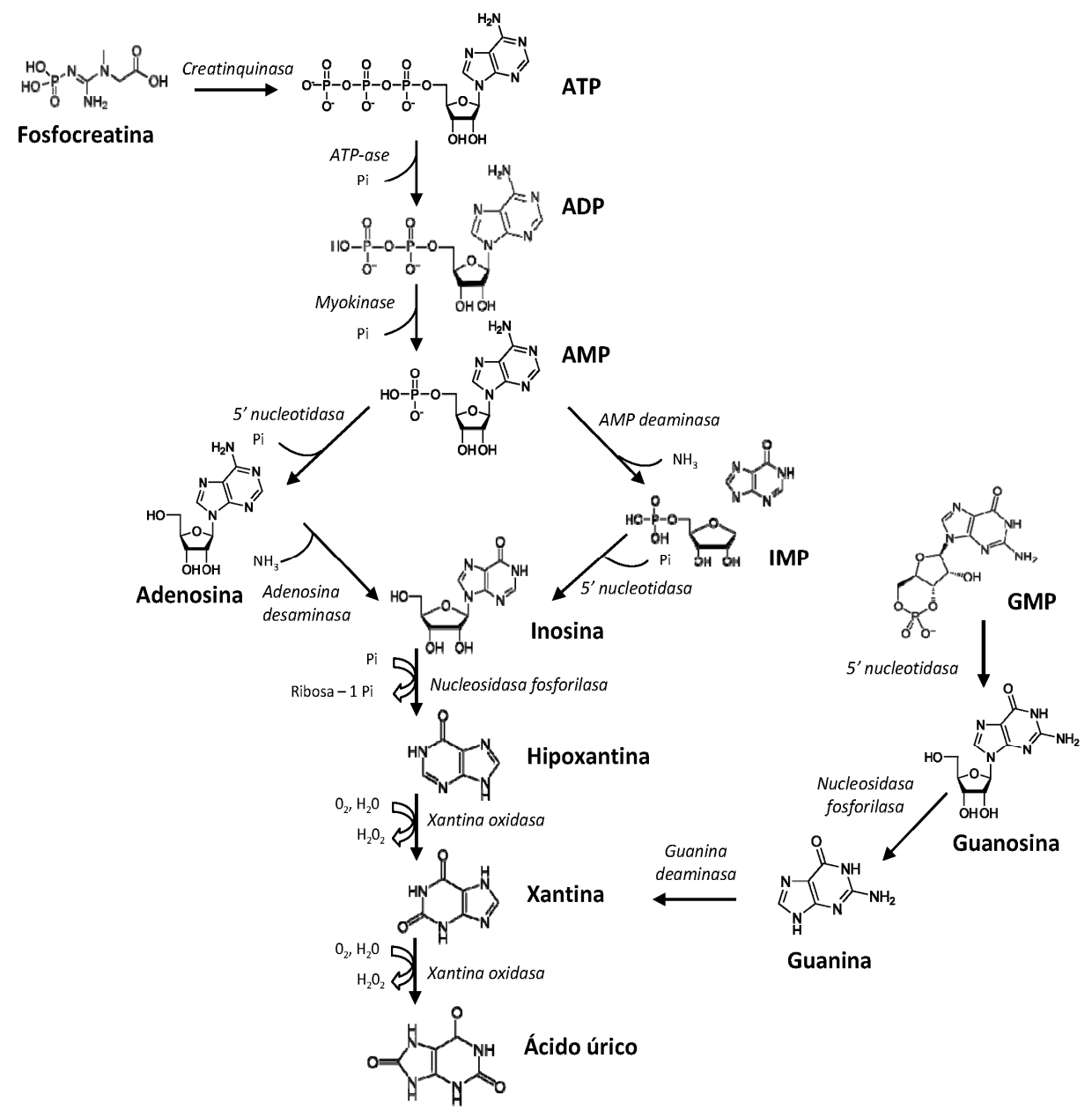

Figura 7. Esquema de la degradación del ATP en el músculo post-mortem. (Adaptación de Aristoy et al., 2009).

Como resultado de los procesos catabólicos del ATP, algunos de los compuestos derivados de su degradación o el cociente entre ellos se han propuesto como índices o indicadores de la frescura y maduración en diversas especies de pescado (Saito et al., 1959), conejo y ternera (Nakatani et al., 1986), cerdo y pollo (Fujita et al., 1988, Batlle et al., 2000 y 2001). Aunque, la determinación simple de la concentración de 
Hx acumulada durante el almacenamiento, ha sido considerada también como un excelente índice de la maduración y calidad de la carne (Tsai et al., 1972; Yano et al., 1995a y Batlle et al., 2001). El índice de frescura o valor K (1) propuesto por Saito et al., (1959) se basa en los cambios autolíticos en pescado, proporcionando una puntuación de frescura relativa, de modo que cuando más alto es el valor de $\mathrm{K}$, menor es el nivel de frescura.

$$
K(\%)=\frac{[\operatorname{lno}]+[H x]}{[A T P]+[A D P]+[A M P]+[I M P]+[\operatorname{Ino}]+[H x]} \times 100
$$

Sin embargo, dado que algunos metabolitos como el ATP, ADP y AMP desaparecen a las 24 horas después de la muerte del animal, Karube et al., (1984) sugirieron simplificar el valor $\mathrm{K}$ por el valor $\mathrm{K}^{\prime}$ o $\mathrm{K}_{\mathrm{i}}(2)$.

$$
K_{i}(\%)=\frac{[\operatorname{lno}]+[\mathrm{Hx}]}{[\operatorname{IMP}]+[\operatorname{lno}]+[\mathrm{Hx}]} \times 100
$$

Por su parte, Nakatani et al., (1986) y Fujita et al., (1988) propusieron otro índice $\left(\mathrm{K}_{\mathrm{o}}\right)$, para determinar la frescura en carne de conejo, ternera, pollo y cerdo (3).

$$
K_{0}(\%)=\frac{[I n o]+[H x]+[X]}{[A T P]+[A D P]+[A M P]+[I M P]+[\text { Adenosina }]+[\operatorname{Ino}]+[H x]+[X]} \times 100
$$

En general el valor $\mathrm{K}^{\prime} \mathrm{O} \mathrm{K}_{\mathrm{i}}$ resulto ser el índice más utilizado de frescura del pescado (Mulchandani et al., 1990; Okuma et al., 1992; Carsol y Mascini, 1998) y también de maduración de la carne (Shahidi et al., 1994; Yano et al., 1995; Park et al., 2000; Batlle et al., 2001).

A partir de estas relaciones y debido a la gran variabilidad en el contenido de nucleótidos y sus derivados encontrados en diferentes especies de pescado, se han propuesto nuevos índices de frescura y calidad. Luong y Male (1992) propusieron la 
utilización del valor $\mathrm{H}$ (4) para especies de pescado con altas concentración de Ino e $\mathrm{Hx}$, aunque Park et al., (2000) han utilizado este índice para determinar la frescura en carne de ternera y pollo.

$$
H(\%)=\frac{[H x]}{[I M P]+[I n o]+[H x]} \times 100
$$

Burns et al., 1985, han sugerido la utilización del valor G (5) como indicador de calidad en pescado magro en congelación y el valor $P(6)$ para detectar el nivel de deterioro en las primeras etapas de almacenamiento en refrigeración.

$$
G=\frac{[H x]+[\operatorname{lno}]}{[I M P]+[\operatorname{Ino}]+[A M P]} \quad \text { (5) } \quad P=\frac{[H x]+[\operatorname{lno}]}{[I M P]+[\operatorname{Ino}]+[H x]+[A M P]}
$$

El relación $[\mathrm{Hx}] /[\mathrm{AMP}]$ se consideró una adecuada alternativa para caracterizar la frescura de pescado debido a su incremento constante con el tiempo (Massa et al., 2002), la relación [IMP]/[ATP] fue propuesta para detectar carne PSE (Batlle et al., 2000) y finalmente la $[\mathrm{Hx}]$ para evaluar el tiempo post-mortem como una medida de calidad dada su alta correlación con las perdidas de frescura y deterioro de la carne.

Por otro lado, los nucleótidos y nucleósidos se han relacionado con atributos sensoriales de la carne, algunos de estos compuestos como el IMP y el GMP afectan al sabor de la carne, actuando como potenciadores del mismo y contribuyendo al sabor umami (Aristoy y Toldrá, 2009), mientras que la hipoxantina junto con algunos aminoácidos y péptidos pueden contribuir al sabor amargo en la carne (Tikk et al, 2006).

\subsubsection{Generación de aminas biógenas.}

Las aminas biógenas (AB) son compuestos orgánicos nitrogenados de bajo peso molecular con estructura alifática (putrescina, cadaverina, agmatina, espermina y 
espermidina) y aromática (tiramina, histamina, $\beta$-feniletilamina, octapamina, dopamina, serotonina y triptamina). Se producen principalmente por descarboxilación microbiana de sus aminoácidos precursores (Silla-Santos, 1996) o por aminación y transaminación de los aldehídos y cetonas (Maijala y Eerolas, 1993). En función del número de grupos amino las $A B$ también se clasifican en monoaminas (histamina, feniletilamina, tiramina), diaminas (putrescine, cadaverina) o poliaminas (espermidina, espermina). Las poliaminas, son de origen natural o fisiológico y se forman como consecuencia de distintos procesos metabólicos a partir de la arginina (putrescina, agmatina, espermina y espermidina) o de la lisina (cadaverina). La figura 8 esquematiza las rutas biosintéticas de las $A B$ y las principales enzimas descaboxilasas implicadas. Aunque la síntesis de las aminas naturales sigue rutas más complejas que las de las $A B$, en las primeras etapas también se incluyen reacciones de descarboxilación aminoacídica. Las $A B$ se pueden encontrar en alimentos como el pescado, pero también en aquellos con alto contenido de proteína y que han sufrido una fermentación con gran liberación de aminoácidos como por ejemplo, queso, productos cárnicos crudos-curados (embutidos), vino, cerveza, etc.

Las diaminas y poliaminas son componentes indispensables de las células vivas, a bajas concentraciones son importantes en la regulación de la función de los ácidos nucleicos, síntesis de proteínas y probablemente en la estabilización de las membranas celulares protegiéndolas del estrés oxidativo (Maijala y Eerolas, 1993; Halász et al, 1994). Sin embargo, el consumo de $A B$ en altas concentraciones pueden tener efectos nocivos y provocar dolores de cabeza, hipo e hipertensión, náuseas, palpitación cardiaca, intoxicación renal, en casos graves hemorragia cerebral e incluso la muerte (Shalaby, 1996). La putrescina y cadaverina pueden reaccionar con nitrito dando lugar a la formación de nitrosaminas, sustancias con efecto cancerígeno. Las monoaminas, histamina y tiramina, tienen propiedades vasoactivas 
y psicoactivas que provocan hipotensión, migrañas e hipertensión. Además de sus efectos toxicológicos, las $A B$ están relacionadas con la higiene de los alimentos, su presencia en elevadas concentraciones puede ser indicativa de uso de materias primas de baja calidad, de contaminación y condiciones inapropiadas durante el procesamiento y almacenamiento de los alimentos (Bover-Cid et al., 1999).

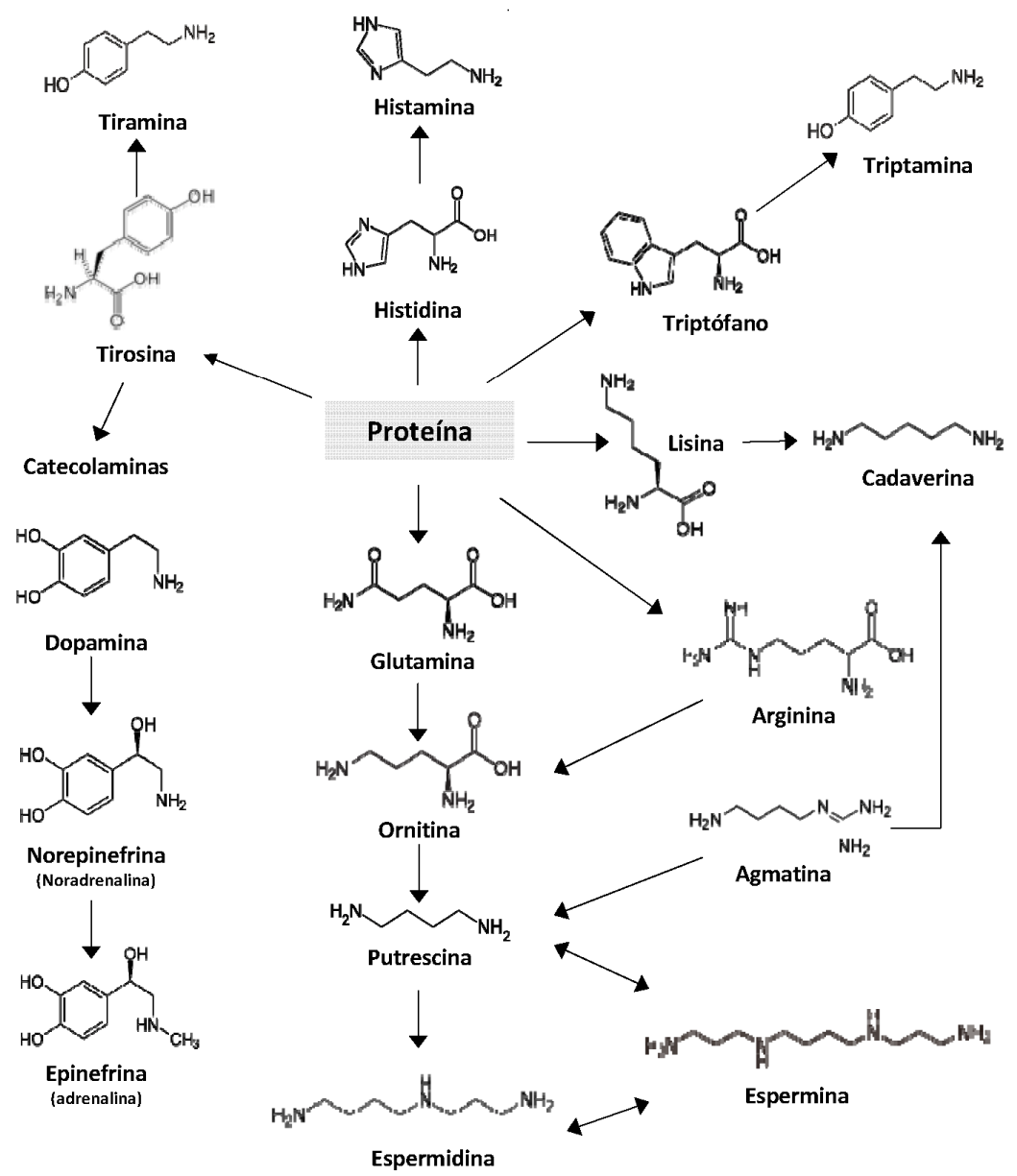

Figura 8. Ruta metabólica de la formación de aminas biógenas. (Modificado de Halász et al., 1994). 1.Histidín-descarboxilasa, 2.Lisina-descarboxilasa, 3.Ornitina-descarboxilasa, 4.Tirosina-descarboxilasa, 5.Triptófano-descarboxilasa. 
La carne fresca, en condiciones normales debe contener tan solo poliaminas fisiológicas (espermina y espermidina); sin embargo, contiene una elevada actividad de agua y un alto contenido en nutrientes que contribuyen y favorecen el desarrollo de microorganismos indeseables que se relacionan con alteraciones de la carne $y$ son capaces de producir $A B$, por lo que pueden ser utilizadas como compuestos marcadores de la calidad. En los productos crudos curados sometidos a un proceso de fermentación y/o maduración, el desarrollo y la actividad de una gran variedad de microorganismos (potenciales aminogénicos), los procesos proteolíticos que aumentan la disponibilidad de aminoácidos precursores y una ligera acidificación contribuyen a la formación de $A B$. En el caso del jamón (producto madurado a partir de piezas enteras) la formación de $A B$ esta fuertemente limitada por la cantidad de sal adicionada, por lo que su concentración es muy baja. Además, los recuentos microbianos son muy bajos en este producto.

\subsubsection{Otros cambios debidos a reacciones químicas.}

\section{Degradación y oxidación de los lípidos}

La degradación de los lípidos consiste en primer lugar en una hidrólisis enzimática, como anteriormente fue descrito, generando ácidos grasos libres que son susceptibles de oxidación. Esta oxidación se inicia con la formación de radicales libres por acción de distintos catalizadores como la luz, oxígeno, iones metálicos, temperatura, humedad o enzimas como la lipoxigenasa, formándose hidroperóxidos. Aunque estos compuestos carecen de olor, van a ser el origen de los productos secundarios de la oxidación, rompiéndose en moléculas volátiles de bajo peso molecular (aldehídos, cetonas, alcoholes, hidrocarburos y ácidos) o reaccionando con proteínas, péptidos y aminoácidos que según su composición pueden ocasionar malos olores o contribuir a la mejora del aroma (Toldrá, 1994; Estévez et al., 2009). 


\section{Reacción de Maillard}

La reacción de Maillard (glucosilación no enzimática de las proteínas) es una de las principales rutas de formación del aroma de la carne y productos cárnicos. Esta reacción ocurre cuando los grupo amino libres de compuestos proteicos (proteínas, péptidos o aminoácidos) se combinan con los grupos carbonilo de los azúcares para formar glucosilaminas. Esta reacción ocurre a cualquier temperatura, pero sucede más rápidamente a altas temperaturas, es responsable del color, aroma y sabor durante diferentes formas de preparación de alimentos. Dentro de los compuestos del aroma a carne destacan los compuestos azufrados, que se forman de la combinación de los azúcares reductores con cisteína o metionina vía la degradación de Strecker (Mottram, 1998). En el jamón curado la formación de este tipo de productos ocurre durante la fase final de la maduración, cuando las condiciones ambientales de la cámara son favorables y disminuye la actividad de agua (Ventanas et al., 1992), generando un gran número de compuestos volátiles: carbonilos (aldehídos y cetonas), furanos, ácidos grasos, pirazinas y compuestos azufrados (sulfuros, tiazoles, tioles y tiofenos) (García et al., 1991; Flores et al, 1997).

\section{Reacción de Strecker.}

Las reacciones de Strecker constituyen otra ruta de formación de compuestos volátiles y forma parte del mecanismo de pardeamiento no enzimático (Cremer y Eichner, 2000), involucrando la desaminación oxidativa y la descarboxilación de aminoácidos en presencia de compuestos $\alpha$-dicarbonilos, para producir aminocetonas, aldehídos y dióxido de carbono (Figura 4). Los compuestos generados poseen características aromáticas intensas y pueden contribuir al desarrollo del aroma final característico del jamón curado. 


\subsection{Métodos analíticos para la determinación de nucleótidos y sus derivados y de aminas biógenas en la carne y productos cárnicos.}

\subsubsection{Nucleótidos y sus derivados}

Los métodos analíticos propuestos para el análisis de nucleótidos y sus derivados incluyen en primer lugar la extracción de los compuestos de estudio de la matriz cárnica. A fin de realizar un análisis correcto de los compuestos relacionados con el ATP se debe tener en cuenta que el músculo en sus primeros momentos postmortem es muy sensible a la temperatura y la degradación del ATP ocurre muy rápidamente, incluso a temperatura de refrigeración (Aristoy et al., 2010). Durante la toma de muestras es muy importante detener esa degradación para lo cual el músculo recién extraído se congela inmediatamente mediante inmersión en nitrógeno líquido (Batlle et al., 2000). A partir de aquí, el procedimiento típico de extracción y desproteinización consiste en homogenizar las muestras de carne y/o productos cárnicos con un disolvente ácido concentrado como el ácido perclórico (0.6 M) (Saito et al., 1959; Fujita et al., 1988; Batlle et al., 2001) o el ácido tricloroacético (Jones et al., 1964; Okuma y Abe, 1992), que desnaturalizan las enzimas de degradación del ATP y desproteiniza la muestra. A continuación, los extractos cárnicos ácidos se neutralizan $(\mathrm{pH}$ 7.0) con carbonato potásico o hidróxido de potasio para estabilizar la muestra. Los extractos cárnicos parecen ser estables si se mantienen congelados $\left(-25^{\circ} \mathrm{C}\right)$ por varias semanas.

Para el análisis de nucleótidos y sus derivados se ha utilizado una gran variedad de métodos tales como la cromatografía en capa fina (Dingle et al., 1968), espectroscopia de resonancia magnética nuclear (Van den Thillart et al., 1990), electroforesis capilar (Nguyen et al., 1990; Luong et al., 1992), radioinmunoensayos (Roberts et al., 1991), cromatografía líquida de alta resolución (HPLC) de intercambio iónico (Lamb y Ye, 1992; Gao et al., 2006), en fase reversa (RP-HPLC) (Veciana Nogués et al., 1997; Kuda et al., 2007), en fase reversa con par iónico (IP-RP-HPLC) 
(Murray y Thomson, 1983; Meynial et al., 1995; Veciana-Nogués et al., 1997). Además, se han desarrollado algunas técnicas enzimáticas utilizando sensores enzimáticos, como se describirán en el apartado 1.4.4.

EI HPLC es la técnica más empleada para el análisis específico de los compuestos derivados de la degradación del ATP en carne (Tsai et al., 1972; Batlle et al., 2000 y 2001) y productos cárnicos (Mateo et al., 1996). En particular, la RP-HPLC e IP-RPHPLC son los métodos de elección y dependiendo del analito de interés será el tipo de separación. El análisis cromatográfico en RP-HPLC se desarrolla normalmente en un cromatógrafo de líquidos equipado con un detector ultravioleta (254nm) (Diode Array Detection, DAD) y se caracteriza por separar moléculas en base a su polaridad. La columna más utilizada en este tipo de análisis es una columna tipo C18, que consiste en un soporte de sílice con cadenas $n$-alquil $(n=18)$ enlazadas. La separación de los analitos suele realizarse utilizando un tampón fosfato a diversos $\mathrm{pH}$ como fase móvil, aunque para mejorar la resolución de los compuestos y reducir el tiempo del cromatógrama se puede combinar con una elución en gradiente con metanol o acetonitrilo. La identificación de los compuestos se realiza mediante la comparación de los tiempos de retención y sus espectros con los patrones respectivos. La adición de par iónico, generalmente sales de amonio cuaternarios, a la fase móvil incrementa el tiempo de retención (Veciana-Nogués et al., 1997) y mejora la separación de moléculas cargadas como los nucleótidos (ATP, ADP, AMP). El mecanismo que se genera hace a la técnica menos dependiente del tipo de columna y de la resolución debido a la naturaleza de los ésteres fosfato que facilitan la fuerte interacción con el par iónico a un apropiado pH de la fase móvil (Aristoy et al., 2010). Sin embargo, este método es más costoso que la RP-HPLC, ya que los reactivos de par iónico son caros. Recientemente, se ha empleado la cromatografía líquida de ultra alta resolución con espectrometría de masas en tándem (UPLC-MS/MS) para 
analizar los nucleótidos y nucleósidos de la carne fresca, jamón curado y jamón cocido (Clariana et al., 2010).

\subsubsection{Aminas biógenas}

El interés en analizar las $A B$ de un alimento se debe en gran parte a su potencial toxicidad, pero también a que pueden ser utilizadas como marcadores de calidad. Así pues, el análisis de las $A B$ ha sido enfocado al control de calidad de las materias primas, productos intermedios y productos finales, al seguimiento de los procesos de fermentación y al control de procesos (Önal, 2007). La cromatografía en capa fina (Latorre-Moratalla et al., 2009) resultó ser un método simple, rápido y económico, pero la mayoría de los trabajos publicados indican que se requiere de excesivo tiempo para el análisis y los resultados obtenidos tan solo permiten la semicuantificación del contenido de $A B$. La cromatografía de gases se ha utilizado también para el análisis de aminas, pero esta técnica ha sido adecuada para el análisis de compuestos volátiles, por lo que además de extraer la muestra hay que formar esos compuestos, alargando y complicando el análisis. Staruszkiewicz y Bond, (1981), han utilizado esta técnica para la detección de putrescina y cadaverina en pescado y camarón. Otros métodos como la electroforesis capilar (Lange et al., 2002) o la combinación de ésta con técnicas de detección conductimétrica (Kvasnicka y Voldrich, 2006) para reducir los tiempos y costo del análisis en productos como salami, queso, vino y cerveza han sido utilizadas.

En el caso de la cromatografía líquida para la determinación de $A B$ es necesario realizar un paso adicional de derivatización, pre o post-columna, con el fin de facilitar su determinación, debido a que muchas $A B$ carecen de grupos cromóforos para su determinación directa. Aunque estos métodos consumen mucho tiempo, la IP-RP-HPLC con derivatización post-columna seguida de detección fluorescente (Veciana Nogués et al., 1995; Hernández-Jover et al., 1996) ha sido el método que 
más veces se ha citado en el análisis de $A B$ en carne y productos cárnicos. Dicho método conlleva la formación de pares iónicos entre las $A B$ y el octanosulfonato sódico que se adiciona a la fase móvil y la separación se realiza previa derivatización con orto-ftaldehído. Recientemente, se ha empleando la cromatografía líquida de ultra alta resolución (UHPLC) con derivatización post-columna para separar y cuantificar AB (Latorre-Moratalla et al., 2009) en carne, jamón curado y jamón cocido. Por otro lado, también se han desarrollado métodos enzimáticos basados en la actividad de la mono y diamino oxidasa (Yano et al., 1995b; Bouvrette et al., 1997) como se describe en el apartado 1.4.4.

\subsection{Biosensores}

La industria alimentaria actualmente demanda herramientas de monitorización y control que puedan brindar datos en tiempo real para el aseguramiento de la calidad fisicoquímica, microbiológica, bromatológica, sensorial y de la estabilidad de materias primas procesos y productos (Jiménez y León, 2009). Los métodos analíticos tradicionales carecen en muchos casos de la sensibilidad adecuada para la determinación a nivel de trazas, además de tener poca especificidad. Aunque los métodos cromatográficos constituyen herramientas robustas, reproducibles $y$ sensibles, son costosos e implican tratamientos exhaustivos de la muestra. En este contexto, el uso de biosensores constituye una alternativa para inspeccionar la calidad del producto y de los procesos debido a su especificidad, selectividad, versatilidad, sencillez, corto tiempo de análisis, bajo costo y fácil manejo.

El biosensor según la IUPAC (International Union of Pure and Applies Chemistry) se define como un dispositivo analítico que incorpora un elemento biológico, íntimamente asociado con un transductor fisicoquímico, que en presencia del analito produce una señal eléctrica que es proporcional a la cantidad presente del mismo (Turner et al., 1987). El principio de detección se basa en la interacción específica 
entre el compuesto de interés (analito) y el elemento de reconocimiento biológico (enzima, anticuerpos, tejidos, receptores celulares, microorganismos o ácidos nucleicos), que produce variación en una o varias propiedades físico-químicas ( $\mathrm{pH}$, transferencia de electrones, calor, cambios de masa, variación de las propiedades ópticas, cambios de potencial, etc.) en el medio de reacción, las cuales son detectadas por un transductor específico que debe ser capaz de convertir esa reacción biológica en una señal detectable (Prodromidis y Karayannis, 2002). La señal luego es amplificada y procesada y estará relacionada con la concentración del analito (Figura 9). El transductor, determina la eficacia (sensibilidad) en el procesamiento de la señal del biosensor, mientras que la selectividad se define por la particular interacción del componente biológico con el analito.
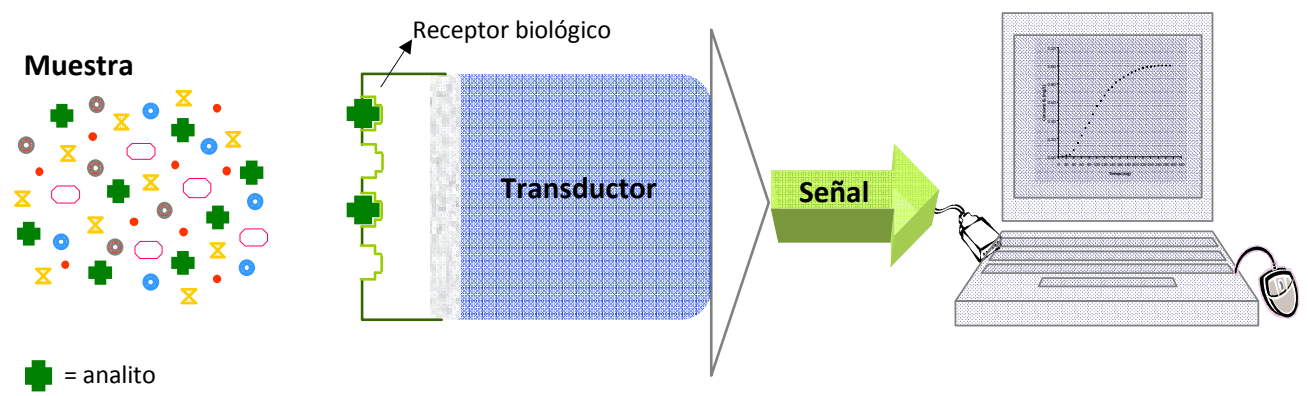

Figura 9. Esquema genérico de un biosensor

Así pues, los biosensores se clasifican atendiendo a diferentes criterios, como la naturaleza del elemento de reconocimiento (catalíticos y de afinidad) o el tipo de transductor utilizado (electroquímico, óptico, piezoeléctrico y térmico), siendo este último el sistema más aceptado, aunque puede darse una combinación de ambos.

\subsubsection{Clasificación de los biosensores por su elemento de reconocimiento.}

\subsubsection{Biosensores catalíticos.}

Estos biosensores, se basan en la utilización de catalizadores (enzima, anticuerpos, tejidos, receptores celulares, microorganismos) como elementos de 
reconocimiento biológico, los cuales favorecen que ocurra una reacción química a partir de uno o varios sustratos para producir uno o varios productos, sin el consumo del biocatalizador, que se regenera y puede ser reutilizado. Las enzimas son los elementos más comúnmente utilizados para la fabricación de estos biosensores debido a su bajo costo, disponibilidad en el mercado y fácil manipulación (Eggins, 2002), denominándose sensores enzimáticos y serán descritos con detalle en el apartado 1.4.3.

\subsubsection{Biosensores por afinidad.}

La operación de estos biosensores se basa en la interacción del analito de interés con el elemento de reconocimiento que pueden ser macromoléculas (ácidos nucleicos, anticuerpos carbohidratos, ADN, ARN) o ensambles moleculares organizados. Es decir, monitorizan la unión del analito con su receptor sin llevar a cabo transformaciones químicas (Jiménez y León, 2009), pero producen una reacción de equilibrio en la que se forma un complejo analito-receptor (Mello y Kubota, 2002). Dicha interacción demanda sistemas de alta sensibilidad y precisión para ser detectadas y su cuantificación se realiza de forma indirecta a través del seguimiento cinético del proceso en presencia de inhibidores competitivos, marcaje isotópico, comportamiento óptico del proceso o variaciones gravimétricas (Jiménez y León, 2009). Entre ellos se encuentran los inmunosensores y los basados en quimiorreceptores.

\subsubsection{Clasificación de los biosensores por su tipo de transducción.}

\subsubsection{Biosensores electroquímicos}

En los últimos 30 años, los biosensores electroquímicos han cobrado gran importancia, especialmente en aplicaciones industriales y se han convertido en los más utilizados debido a sus ventajas prácticas, simplicidad de operación, bajos costos de fabricación y detección en tiempo real (Dzyadevych et al., 2008). Estos 
sensores químicos o biosensores electroquímicos se basan en el hecho que durante un proceso de bio-interacción, especies electroquímicas como los electrones se consuman o generen produciendo una señal electroquímica que a su vez puede ser medida por un detector electroquímico, que luego es amplificada, procesada y convertida a la forma deseada (Figura 9). En función del tipo de señal electroquímica, estos biosensores se pueden clasificar en amperométricos, potenciométricos y conductimétricos.

\section{a. Amperométricos.}

Dentro de los biosensores electroquímicos, los amperométricos son los que han mostrado mayor avance, debido a su extensa aplicación dentro del análisis médico llegando a ser una herramienta prometedora en el área de alimentos. Éstos miden los cambios de corriente en un electrodo de trabajo (platino, oro, derivados del grafito - carbono vitrificado o grafito pirolítico-, polímeros conductores, etc.) como resultado de la aplicación de un potencial fijo sobre un electrodo de referencia $(\mathrm{Ag} / \mathrm{AgCl})$, debido a la oxidación de los sustratos o productos de una reacción bioquímica. Los transductores amperométricos se fundamentan en la proporcionalidad que existe entre la concentración de una determinada especie electroactiva y la corriente eléctrica registrada (Chaubey y Malhotra, 2002). Esta relación se comporta según el modelo simplificado de la Ley de difusión de Fick (7), obteniéndose una relación lineal entre ellos. La corriente que se origina durante la reacción química es de tipo faradaico y es una medida de la velocidad de la reacción electroquímica que se produce en el electrodo.

$$
I=\frac{n F A D_{0}}{\delta} C_{0} ; \text { simplificando } \mathrm{I}=\mathrm{K} C_{0}
$$

donde, F, es la constante de Faraday, A es el área del electrodo de trabajo, $\mathrm{D}_{\mathrm{o}}$ y $\mathrm{C}_{\mathrm{o}}$ son los coeficientes de difusión y la concentración del analito, respectivamente y $\delta$ tamaño de la capa de difusión. 


\section{b. Potenciométricos.}

El fundamento teórico de estos sensores se establece por la ecuación de NernstDonnan (8), la cual se basa en la determinación de la diferencia de potencial (voltaje) entre un electrodo de trabajo y un electrodo de referencia. Funcionan en condiciones de equilibrio, a corriente cero, y monitorizan la acumulación de carga creada por la actividad del propio analito.

$$
E=E^{O}+\frac{R T}{n F} \ln a_{i}+\sum_{j} k_{i, j}^{p o t} * a_{j}^{z_{i} / z_{j}}
$$

donde, $a_{i}$ es la actividad del ión principal, $a_{j}$ la actividad del ión interferente, $z_{i}$ y $z_{j}$, las cargas de los iones principal e interferentes, y $k_{i, j}^{\text {pot }}$ es el coeficiente de selectividad.

Estos dispositivos constan de un dispositivo de medida del potencial, un electrodo de referencia y una membrana selectiva de iones (ISE) o de gases, como electrodo de trabajo (Terry et al., 2005). En matrices biológicas complejas la ISE puede detectar iones como el $\mathrm{Na}^{+}, \mathrm{K}^{+}, \mathrm{Ca}^{2+}, \mathrm{H}^{+} \circ \mathrm{NH}_{4}{ }^{+}$mediante la detección de cambios en el potencial del electrodo cuando los iones se unen a una membrana de intercambio iónico adecuada. Barat et al., (2008) propusieron la utilización de este tipo de sensor para el seguimiento del tiempo post-mortem y la frescura del pescado, mediante su correlación con el valor $\mathrm{K}_{1}$ (ver apartado 1.2.4.).

Recientemente han aparecido un nuevo tipo de sensores selectivos de iones denominados "sensores voltamperométricos" los cuales miden la variación de la corriente cuando cambia el potencial. Estos utilizan un sistema de tres electrodos: un electrodo de trabajo, un electrodo de referencia y un electrodo auxiliar o contraelectrodo (platino) que permite conducir la electricidad desde la fuente que la produce hasta el electrodo de trabajo. En este subgrupo se pueden incluir los sensores basados en electrodos químicamente inertes, electrodos químicamente 
activos y electrodos modificados. Santos et al., (2009) propusieron la aplicación de esta técnica para la determinación de nitrito en embutidos y vegetales en salmuera.

\section{c. Conductimétricos.}

Este tipo de dispositivos miden los cambios de conductividad entre dos pares de electrodos metálicos a un voltaje constante, como consecuencia de reacciones bioquímicas que específicamente consumen o producen iones (Chaubey y Malhotra, 2002), ya sea en la disolución de medida o en una membrana selectiva. En uno de los pares de electrodos se coloca la membrana con el elemento de reconocimiento mientras que en el segundo par se coloca una membrana en blanco. Así, la presencia de elementos iónicos en una muestra genera un incremento en la conductividad $(\wedge)$ que es proporcional a la concentración de iones, según la ecuación (9). La desventaja de estos sensores es la alta fuerza iónica de las matrices biológicas lo que dificulta la detección de pequeños cambios de conductividad causados por la reacción bioquímica (Mikkelsen y Rechnitz, 1989).

$$
\wedge=\frac{k}{C}
$$

donde, $\mathrm{k}$ es la conductividad especifica y $\mathrm{C}$ es la concentración de iones.

\subsubsection{Biosensores Ópticos}

Estos sensores se basan en la medida de la variación de las propiedades ópticas (absorbancia, reflectancia, fluorescencia, índice de refracción, dispersión de la luz, efecto optotérmico) como consecuencia de la interacción del analito con la parte receptora (Figura 10). Estos dispositivos presentan la ventaja de no ser destructivos, pero la unión no específica del analito produce señales falsas. Entre éstos se destaca los sensores de fibra óptica que han sido aplicados al aseguramiento de la calidad microbiológica de embutidos mediante la detección de Listeria monocytogenes (Geng et al., 2004) o Escherichia coli 0157:H7 (Radke y Alocilja, 2005). 


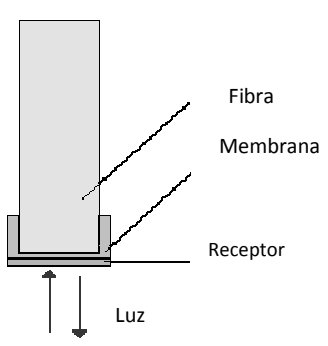

Figura 10. Esquema general de un biosensor óptico.

\subsubsection{Biosensores Térmicos}

Estos dispositivos son capaces de medir la concentración de un sustrato utilizando la variación de entalpía de la interacción entre el analito y el receptor, convirtiéndolo en una señal eléctrica. Una enzima inmovilizada (Figura 11) transforma al sustrato y libera o consume calorías durante la reacción que puede detectarse en los termistores o dispositivos piroeléctricos. Existe en el mercado, uno de estos sensores, el ThermoMetric ${ }^{\circledR}$ (ThermoMetric Inc. Jarfalla, Sweden, Luong et al., 1997). Estos biosensores se han aplicado también a la detección de interacciones antígenoanticuerpo; sin embargo, estos instrumentos son sofisticados y caros lo que es el mayor inconveniente de esta técnica.

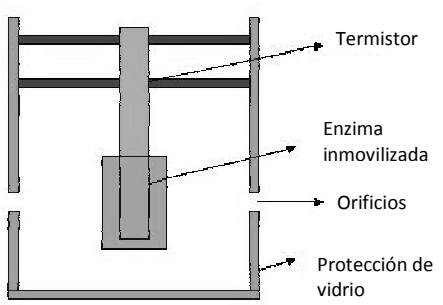

Figura 11. Esquema general de un transductor termométrico.

\subsubsection{Biosensores Piezoeléctricos}

Conocidos también con el nombre de sistemas de traducción másicos, gravimétricos o acústicos. Son dispositivos que, sobre una superficie de un cristal piezoeléctrico (cuarzo) o un dispositivo de onda acústica superficial, se detecta la 
variación en la frecuencia de resonancia característica del cristal debido a un aumento de masa (Terry et al., 2005). En el sector alimentario ha permitido el seguimiento de propiedades reológicas como la textura mediante la detección de vibraciones por fractura de la muestra de interés (Taniwaki et al., 2006).

\subsubsection{Sensores enzimáticos}

Los sensores enzimáticos se incluyen dentro de los biosensores de tipo catalítico (apartado 1.4.1.) y se han elegido para el desarrollo de este trabajo por su adecuación al análisis de los analitos de interés; nucleótidos y sus derivados (Watanabe et al., 1983) y aminas biógenas (Bouvrette et al., 1997; Yano et al., 1996).

El concepto de "electrodo enzimático" fue introducido por Clark y Lyons en 1962 (Clark y Lyons, 1962) para determinar la concentración de glucosa en la sangre a través de la reacción catalizada por la glucosa oxidasa acoplada a un electrodo selectivo de oxígeno. Incluso, fue el primer biosensor disponible comercialmente (Yellow Spring Instrument, USA) en 1975.

Los biosensores electroquímicos basados en enzimas (sensores enzimáticos) son dispositivos que combinan la ventaja de la elevada selectividad, especificidad y versatilidad de las enzimas para reconocer moléculas particulares, con un transductor para medir la concentración de un analito. Las enzimas son proteínas capaces de catalizar una reacción química. Reaccionan de manera selectiva con el analito. El mecanismo básico de la catálisis enzimática para reacciones en las que se ve involucrado un único sustrato, es el siguiente (10):

$$
\mathrm{E}+\mathrm{S} \underset{\mathrm{k}_{-1}}{\stackrel{\mathrm{k}_{1}}{\rightleftarrows}} \mathrm{E}-\mathrm{S} \underset{\mathrm{k}_{2}}{\longrightarrow} \mathrm{E}+\mathrm{P}
$$


donde $\mathrm{S}$ es el sustrato, E la enzima, E-S el complejo enzima-sustrato y $\mathrm{P}$ el producto, $k_{1}$., $k_{2}$., $k_{-1}$.son las constantes cinéticas para cada una de las etapas de reacción. Así, para una concentración de enzima determinada, la velocidad de reacción catalizada enzimáticamente se define por la ecuación de Michaelis-Menten (11).

$$
v=\frac{\left[E_{o}\right] V_{\max }}{k_{M}+[s]}
$$

donde $\mathrm{V}_{\max }$ es la velocidad máxima de reacción y $\mathrm{k}_{\mathrm{M}}$ es la constante de MichaelisMenten que corresponde a la concentración de sustrato para la cual la velocidad es igual a la mitad de la velocidad máxima. La actividad enzimática esta regulada por el $\mathrm{pH}$, la fuerza iónica del medio y la temperatura y, requiere en algunos casos la presencia de un cofactor (nicotinamida adenín dinucleótido $-\mathrm{NAD}^{+}$u oxígeno) para que se ocurra la reacción. La zona activa o sitio activo de las enzimas les confieren la especificidad y suele estar situada en el interior de éstas. Existen diferentes tipos de enzimas, clasificadas según el tipo de reacción que llevan a cabo (Tabla 4.).

Tabla 4. Clasificación de enzimas según el tipo de reacción que catalizan.

\begin{tabular}{|c|c|}
\hline Enzima & Tipo de reacción \\
\hline - Transferasas & $\begin{array}{l}\text { Catalizan la transferencia de un grupo químico, de un } \\
\text { sustrato a otro. }\end{array}$ \\
\hline - Hidrolasas & $\begin{array}{l}\text { Catalizan reacciones de hidrólisis. Rompen las biomoléculas } \\
\text { con moléculas de agua. }\end{array}$ \\
\hline - Liasas & $\begin{array}{l}\text { Catalizan adiciones de grupos a dobles enlaces o } \\
\text { formaciones de dobles enlaces por eliminación de grupo. }\end{array}$ \\
\hline - Isomerasas & $\begin{array}{l}\text { Catalizan la interconversión de isómeros. Cuando un } \\
\text { isómero se transforma a otro. }\end{array}$ \\
\hline - Ligasas & $\begin{array}{l}\text { Catalizan la formación de enlaces C-C, C-S, C-O Y C-N por } \\
\text { reacciones de condensación acopladas a la hidrólisis de ATP. }\end{array}$ \\
\hline - Oxidoreductasas & $\begin{array}{l}\text { Catalizan reacciones de oxidorreducción. Transferencia de } \\
\text { hidrógeno o electrones de un sustrato a otro. }\end{array}$ \\
\hline
\end{tabular}


Las enzimas comúnmente utilizadas en el diseño de los sensores enzimáticos son de tipo oxido-reductasas, ya que en la conversión enzimática del sustrato (oxidación) tiene lugar una reacción de transferencia de electrones (Reviejo y Pingarrón, 2000; Thévenot et al., 2001) y con ello el cambio de la enzima a estado reducido, que dependiendo de la capacidad de la enzima para donar dos o cuatro electrones al oxígeno $\left(\mathrm{O}_{2}\right)$, el producto final puede ser agua $\left(\mathrm{H}_{2} \mathrm{O}\right)$ o peróxido de hidrógeno $\left(\mathrm{H}_{2} \mathrm{O}_{2}\right)$ (Figura 12).

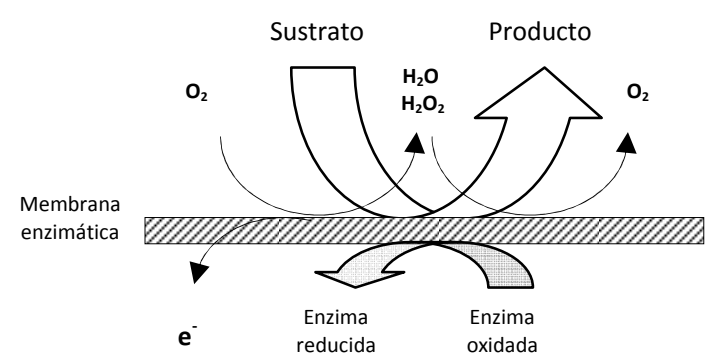

Figura 12. Secuencia de una reacción de oxidación catalizada por una enzima oxidasa empleando oxígeno molecular como aceptador de electrones (Modificado de Reviejo y Pingarrón, 2000).

En el caso de los sensores con enzimas deshidrogenasas (Haouz et al., 1994) es necesaria la presencia del cofactor $\mathrm{NAD}^{+}$y el seguimiento de la reacción catalítica se realiza mediante la oxidación de $\mathrm{NADH}$. El inconveniente de estos cofactores es la necesidad de aplicar potenciales muy altos, que pueden oxidar o reducir a su vez otros analitos que haya en el medio y puedan interferir con la señal detectada.

En este sentido, el correcto funcionamiento de un sensor enzimático depende en gran medida de la naturaleza de la enzima pero también de su inmovilización, del material de soporte que se utilice en ésta y del material con que se construya el transductor. 
1.4.3.1. Inmovilización de la enzima.

Aunque existen métodos enzimáticos que utilizan la enzima libre en disolución (Luong et al., 1992), los más frecuentes son aquellos en los que la enzima se encuentra inmovilizada en un soporte. La inmovilización de la enzima es el proceso más importante en la construcción del sensor, ya que características como el tiempo de vida, sensibilidad y estabilidad durante el almacenamiento, dependen en gran medida de este proceso. Entre las ventajas del empleo de la enzima inmovilizada cabe destacar el aumento de la estabilidad de la enzima y su posible reutilización, disminuyendo el costo del proceso. Sin embargo, la inmovilización puede alterar su conformación resultando en pérdidas en su actividad catalítica. Estas limitaciones han sido minimizadas y se han desarrollado numerosas técnicas de inmovilización. En general, los métodos de inmovilización de enzimas se clasifican en dos grandes grupos; retención física (atrapamiento, microencapsulación) y retención química (adsorción a la superficie, acoplamiento covalente o por entrecruzamiento o crosslinking) (Sharma et al., 2003; Eggins, 2002; Nunes y Marty, 2006). A continuación se describen los tipos de inmovilización más comúnmente utilizados en la fabricación de éstos sensores enzimáticos.

- Atrapamiento físico. Retención física de la enzima en las cavidades interiores de una matriz sólida porosa (polímeros de poliacrilamida, celulosa, colágeno, alginato, carragenato, resinas de poliuretano o membranas de diálisis, grafito más agente aglutinante). La enzima no sufre ninguna alteración en su estructura. La desventaja de este sensor es la barrera creada que dificulta la difusión del analito hasta el centro activo de la enzima, aumentando el tiempo de respuesta. Por lo tanto se requiere de un control riguroso de las condiciones de polimerización.

- Microencapsulación. En este método se encapsulan gotas de una disolución enzimática en microcápsulas semipermeables fabricadas de polímetros orgánicos, que permiten el paso de las moléculas de sustrato y productos pero no del enzima. Este método permite que el material biológico esté en contacto directo con el transductor, manteniendo, a su vez, la alta sensibilidad de los enzimas puesto que no se ven afectadas por los cambios de $\mathrm{pH}$, temperatura o fuerza iónica del medio. 
- Absorción en superficie. El principio de inmovilización de este método se basa en la asociación de la enzima a un soporte mediante interacciones iónicas, fuerzas de Van der Waals y puentes de hidrógeno. Es el método más simple de inmovilización y la absorción se obtiene por volatilización del tampón que contiene la enzima y no requiere de reactivos químico, pero no es muy estable y la unión con el soporte es muy débil. El pH, la fuerza iónica y la presencia de iones como cofactores de la enzima influyen en la desorción de la enzima.

- Entrecruzamiento (cross-linking). Esta técnica consiste en la utilización de reactivos bi o multifuncionales (glutaraldehído, hexametildisocianato, 1,5-dinitro-2,4-diflorobenzeno) que originan uniones intermoleculares entre moléculas de enzima. El agente bifuncional tiene dos grupos aldehídos en sus extremos que reaccionan con el grupo amino de una enzima o proteína. El entrecruzamiento permite evitar las pérdidas de actividad enzimática y puede combinarse con otros métodos de inmovilización consiguiéndose una elevada carga enzimática.

- Enlace covalente. La metodología del enlace covalente entre el transductor y la enzima se basa en la activación de grupos químicos del soporte (membrana o reactor) para que reaccionen con núcleofilos de las enzimas (grupos amina, carboxilicos, alcoholes, tioles o imidazol). Precisan del control del pH y la fuerza iónica. La ventaja de este método es que se consiguen tiempos de vida muy largos.

Cabe mencionar que dentro de cada una de estas técnicas de inmovilización existen muchas variantes dependiendo del método de inmovilización utilizado y los materiales utilizados para inmovilizar la enzima. Además, es posible combinar diferentes técnicas de inmovilización.

\subsection{Materiales soporte para la inmovilización de la enzima.}

La selección del material soporte para la inmovilización de la enzima es un parámetro a tomar en consideración para un adecuado funcionamiento del sensor enzimático. Entre los materiales más comúnmente utilizados se encuentran los siguientes: 
a. Polímeros electropolimerizados o preformados. Los polímeros electropolimerizados permiten la incorporación de la enzima en disolución con un monómero (polipirrol, polianilina y politiofeno) que se deposita en la superficie del electrodo y mediante electropolimerización se forma una película polimérica que se adhiere firmemente sobre el electrodo proporcionando una matriz tridimensional que atrapa la enzima (Ghosh et al., 1998). Los polímeros perfomados son películas delgadas de materiales como el nafion, acetato de celulosa, policarbonato, nylon o poliuretano, que se colocan directamente sobre la superficie del electrodo para después inmovilizar la enzima sobre ellos. Algunas de estas membranas, además de ser un material de soporte para la inmovilización, son selectivas y evitan interferencias electroquímicas. Por otro lado, debido a sus características conductoras, los polímeros pueden ser utilizados directamente como electrodos o bien para modificar químicamente a otro tipo de electrodos como es el caso de los de pasta de carbono.

b. Materiales conductores, se utilizan principalmente para la fabricación de "electrodos composite". El material composite es una dispersión de un material sólido conductor oro, platino, teflón, polvo de grafito, carbono vitrificado o grafito pirolítico en una matriz polimérica de características aislantes dadas por el agente aglutinante (aceite de parafina o de silicona), al cual se le puede añadir la enzima o los mediadores electroquímicos. Con este procedimiento se obtienen biosensores con un depósito tridimensional de la enzima, que permite mediante un simple pulido la renovación de la superficie del biosensor (Reviejo y Pingarrón, 2000).

c. Sistemas sol-gel. Sales inorgánicas de metales o compuestos organometálicos que se someten a reacciones de hidrólisis y polimerización hasta formar una suspensión coloidal o sol, que mediante diversos procesos de pulverización o centrifugado, las partículas condesan en una nueva fase (gel). La enzima se añade durante esta transición y queda retenida en las cavidades de la matriz (Prodomidis y Karayannis, 2002).

d. Electrodos modificados: Modificación del electrodo, principalmente los de pasta de carbono, con polímeros conductores, partículas coloidales u otro tipo de nanomateriales (nanotubos, nanocables de carbono y nanopartículas de oro). La utilización de estos últimos materiales, aún cuando se caracterizan por su simplicidad y proporcionan alta sensibilidad, la aplicación al análisis de muestras reales es mínimo (Agüi et al., 2006). 


\subsection{Materiales de construcción del transductor}

Los materiales de construcción del transductor más utilizados en la construcción de los biosensores electroquímicos son: los metales nobles (oro, platino), carbono (pasta o varillas), conductores composite (polvo de grafito dispersado sobre polímeros de resina epoxi, silicona, metacrilato o poliuretano), sales y polímeros orgánicos conductores o metales sintéticos con cualidades eléctricas y ópticas (polipirrol, polifuranos, poliindoles, policarbazoles y polianilinas) (Gerard et al., 2002).

\subsubsection{Principio de operación}

La representación típica del sensor enzimático se muestra en la figura 9 y, opera en varias etapas: el sustrato en disolución se transporta a la superficie del electrodo y se difunde a través de la membrana al punto activo de la enzima. En este punto ocurre la reacción entre el sustrato y la enzima y como consecuencia de ésta, el sustrato se consume y el producto se forma, generando una señal eléctrica (corriente) que es detectada y mostrada en un procesador. Así, la cinética de la reacción enzimática utilizando una enzima oxido-reductora en el sensor enzimático, es controlada por la disminución del contenido del oxígeno o por la reducción del $\mathrm{H}_{2} \mathrm{O}_{2}$ (Figura 12). Como estos compuestos son electro-activos, el progreso de la reacción enzimática puede medirse a través de amperometría, lo que hace que la mayoría de los sensores enzimáticos sean amperométricos (Terry et al., 2005). En estos casos donde la enzima se inmoviliza en una membrana y a su vez se fija en la superficie del transductor y dependen de la concentración del oxígeno ambiental, son denominados biosensores de "primera generación".

El más simple de los sensores enzimáticos amperométricos se basa en un electrodo de oxígeno Clark (Chaubey y Malhotra, 2002). Este electrodo consiste de un cátodo de platino (donde el oxígeno se reduce) y un electrodo de referencia 
$\mathrm{Ag} / \mathrm{AgCl}$. Cuando un potencial de $-0.60 \mathrm{~V}$ es aplicado al electrodo de platino respecto al electrodo $\mathrm{Ag} / \mathrm{AgCl}$, se produce una corriente que es proporcional a la concentración de oxígeno consumido, de acuerdo con el siguiente mecanismo (12),

Cátodo de platino: $\quad \mathrm{O}_{2}+4 \mathrm{H}^{+}+4 e \rightarrow 2 \mathrm{H}_{2} \mathrm{O}$

Ánodo de plata: $\quad 4 \mathrm{Ag}+4 \mathrm{Cl} \rightarrow 4 \mathrm{AgCl}+4 e$

Sin embargo, en estas condiciones se generan corrientes de fondo elevadas (Reviejo y Pingarrón, 2000), cuyo efecto puede verse neutralizado con el uso de membranas permeables al oxígeno y utilizando cantidades mínimas de electrolito (Falck, 1997). Mientras que la reducción del $\mathrm{H}_{2} \mathrm{O}_{2}$ (13) ocurre al aplicar altos potenciales sobre electrodos metálicos como el platino (0.65 V vs. $\mathrm{Ag} / \mathrm{AgCl})$ (Prodomidis y Karayannis, 2002) y a potenciales aún mayores $(0.9-1.15 \mathrm{~V})$ sobre electrodos de carbono (Reviejo y Pingarrón, 2000) lo que conlleva reacciones interferentes de compuestos orgánicos electroactivos (ascorbato, urato, acido úrico, paracetamol).

$$
\begin{array}{ll}
\text { Ánodo Platino: } & \mathrm{H}_{2} \mathrm{O}_{2} \rightarrow \mathrm{O}_{2}+2 \mathrm{H}^{+}+2 e \\
\text { Cátodo } \mathrm{Ag}: & 2 \mathrm{AgCl}+2 e \rightarrow 2 \mathrm{Ag}+2 \mathrm{Cl}
\end{array}
$$

En este caso, la situación se ha podido solventar mediante la utilización de mediadores electroquímicos (aceptadores artificiales de electrones que se encargan de la transferencia electrónica entre el centro activo de la enzima y la superficie del electrodo), sin necesidad de reducir el oxígeno como co-sustrato de la reacción (Chaubey y Malhotra, 2002), aun así, la reacción sigue dependiendo de la concentración de oxígeno. El mediador debe tener buenas propiedades electroquímicas para actuar a potenciales redox próximo a cero, a fin de eliminar las reacciones redox de posibles interferencias. Los ferrocenos y derivados son los mediadores más utilizados en la fabricación de los sensores enzimáticos (Turner et 
al., 1897; Chaubey y Malhotra, 2002). Este tipo de biosensores son denominados de "segunda generación". En los últimos años, se han diseñado algunos otros biosensores, denominados de "tercera generación", en éstos se busca que la transferencia electrónica entre el centro activo de la enzima y la superficie de electrodo se efectúe de manera directa, para ello se ha utilizando la enzima peroxidasa (HRP) a fin de oxidar directamente el $\mathrm{H}_{2} \mathrm{O}_{2}$ generado (Reviejo y Pingarrón, 2000) o bien la utilización de sales conductoras las cuales pueden oxidar directamente la enzima reducida y no requiere de mediadores (Chaubey y Malhotra, 2002). Este tipo de biosensores muestra la mayor selectividad, puesto que trabaja a potenciales muy próximos a los intrínsecos de la enzima, quedando menos expuestos a posibles interferencias.

\subsubsection{Aplicación de los sensores enzimáticos en el sector cárnico.}

La mayoría de los sensores enzimáticos desarrollados en el ámbito agroalimentario se han destinado principalmente al control de calidad de los productos y procesos y a la seguridad alimentaria. Un gran número de aplicaciones se han desarrollado, como así se ha resumido en varias revisiones al respecto (Mello y Kubota, 2002; Venugopal, 2002, Terry et al., 2005), entre ellas cabe destacar la determinación de la glucosa, fructosa, galactosa, lactosa, almidón, glicerol, ácidos (úrico, cítrico, ascórbico, fólico), alcoholes (metanol, etanol), colesterol, peróxido de hidrógeno, microorganismos, patógenos y toxinas, así como parámetros de frescura (nucleótidos y aminas) en zumos de frutas, vino, cerveza, sidra, leche, pescado, carne, frutas y verduras. La aplicación de biosensores en este campo es relativamente reciente, por lo que existen muy pocos equipos comerciales.

En la industria de la carne, el uso de los sensores enzimáticos se ha centrado en la determinación de diferentes índices para la determinación de la frescura, maduración de la carne y/o seguridad alimentaria. En las tablas siguientes se 
resumen las características de algunos sensores enzimáticos encontrados en la bibliografía aplicados a pescado y a matrices cárnicas y mediante el uso de una diversidad de técnicas electroquímicas y de inmovilización. La aplicación de muchos de ellos se basa en la determinación de índices de frescura (valor $K_{1} K_{1}$ y valor $\mathrm{H}$ ) (apartado 1.2.4.) para pescado y en algunos casos se han utilizado para detectar la maduración de la carne (Tabla 5). En estos casos se requiere el uso de sensores multienzimáticos que permiten el análisis de varios compuestos para el cálculo de los índices. Uno de los aspectos más críticos en el desarrollo de los sensores multienzimáticos es el diseño de complejos sistemas de reactores en serie para inmovilizar las enzimas. En algunos casos es necesaria la co-inmovilización de varias enzimas y/o la utilización de sistemas complementarios como el FIA (del inglés: Flow Inyection Analysis) para su operación. Todo esto complica el posterior tratamiento de los datos para obtener una respuesta coherente y útil.

Con miras a simplificar los controles, diversas investigaciones han propuesto la determinación de $\mathrm{Hx}$ como índice de frescura y/o maduración. Así, diversos sensores enzimáticos han sido diseñados para la determinación específica de la Hx (Tabla 6). Estos sensores se basan en la reacción de oxidación de la $\mathrm{Hx}$ catalizada por la enzima xantina oxidasa $(\mathrm{XO})$, midiendo el consumo de oxígeno o la generación de peróxido de hidrógeno durante la reacción. Como anteriormente se ha mencionado, cada uno de los sistemas propuestos conlleva ciertas ventajas y desventajas, debida a la gran diversidad de materiales, métodos de inmovilización y detección utilizados. La mayoría de estos sensores se han diseñado para pescado y en menor medida para pollo y ternera, pero no hay evidencia de la aplicación de estos sensores a productos cárnicos curados. 
Tabla 5. Sensores enzimáticos utilizados para evaluar los índices de frescura y/o maduración de pescado y carne.

\begin{tabular}{|c|c|c|c|c|c|}
\hline Enzima & Transductor & Parámetro & Inmovilización & Matriz & Referencia \\
\hline $\mathrm{XO}, \mathrm{NP}, \mathrm{NT}$ & $\begin{array}{ll}\text { Amperométrico. } & \text { Sensor de } \\
\text { oxígeno } & \end{array}$ & Valor $\mathrm{K}_{1}$ & $\begin{array}{l}\text { Sobre membrana de triacetato del } \\
\text { celulosa conteniendo } 1,8 \text { amino-4- } \\
\text { aminometiloctano activada con } \\
\text { glutaraldehído }\end{array}$ & $\begin{array}{l}\text { Lubina, Caballa, } \\
\text { Platija, Lubina }\end{array}$ & Karube et al ., 1984 \\
\hline $\mathrm{XO}, \mathrm{NP}, \mathrm{NT}$ & $\begin{array}{l}\text { Amperométrico. Doble reactor } \\
\text { multienzimático y sensor de } \\
\text { oxígeno }\end{array}$ & Valor $\mathrm{K}_{1}$ & $\begin{array}{l}\text { En perlas porosas de quitosano } \\
\text { activadas con glutaraldehído }\end{array}$ & Pescado & Okuma et al., 1992 \\
\hline $\mathrm{XO}, \mathrm{NP}, \mathrm{NT}$ & $\begin{array}{l}\text { Amperométrico. Electrodo de } \\
\text { platino vs } \mathrm{Ag} / \mathrm{AgCl}, 0.650 \mathrm{~V}\end{array}$ & Valor $\mathrm{K}_{1}$ & $\begin{array}{l}\text { En membrana } \\
\text { Immunoaffinity" (XO) y en solución } \\
\text { (NP y NT) }\end{array}$ & Carpa & Volpe y Mascini, 1996 \\
\hline $\mathrm{XO}, \mathrm{NP}, \mathrm{NT}$ & $\begin{array}{l}\text { Amperométrico. } \\
\text { multienzimático y sensor de } \\
\text { oxígeno }\end{array}$ & Valor K & $\begin{array}{l}\text { Sobre vidrio de poro controlado (CPG), } \\
\text { aminopropil }\end{array}$ & Pescado & Nanjyo y Yao, 2002 \\
\hline $\mathrm{XO}, \mathrm{NP}, \mathrm{NT}$ & $\begin{array}{l}\text { Amperométrico. Electrodo de } \\
\text { platino vs. } \mathrm{Ag} / \mathrm{AgCl}, 0.7 \mathrm{~V}\end{array}$ & Valor K & $\begin{array}{l}\text { Sobre una membrana de nylon } \\
\text { preactivada (XO y NP) y sobre la pared } \\
\text { de un tubo de poliestireno (NT) } \\
\text { activado con glutaraldehído }\end{array}$ & $\begin{array}{l}\text { Trucha, carpa, } \\
\text { merluza, lenguado }\end{array}$ & Mulchandan \\
\hline $\begin{array}{c}\text { XO, NP, ALF, } \\
A D\end{array}$ & $\begin{array}{l}\text { Amperométrico. Doble reactor } \\
\text { multienzimático y sensor de } \\
\text { oxígeno }\end{array}$ & Valor $\mathrm{K}$ & $\begin{array}{l}\text { En perlas de quitosano y perlas } \\
\text { porosas de vidrio activadas con } \\
\text { glutaraldehído }\end{array}$ & Pescado y mariscos & Okuma y Watanabe, 2002 \\
\hline ALF, NP, XO & $\begin{array}{l}\text { Amperométrico. Electrodo de } \\
\text { platino serigrafiado de tres } \\
\text { electrodos (carbono, } \mathrm{Ag} \mathrm{y} \\
\mathrm{Ag} / \mathrm{AgCl} \text { ) unidos con una película } \\
\text { de poliéster }\end{array}$ & Valor K & $\begin{array}{l}\text { En doble reactor en serie con perlas } \\
\text { porosas de vidrio activadas con } \\
\text { glutaraldehído. }\end{array}$ & Dorada & Carsol y Mascini, 1998 \\
\hline $\begin{array}{l}\text { XO, NP, ALF, } \\
A D, U\end{array}$ & $\begin{array}{l}\text { Amperométrico. Electrodo de } \\
\text { oxígeno }\end{array}$ & Valor Ko & $\begin{array}{l}\text { Ensayos enzimáticos sobre membrana } \\
\text { en el Freshness meter KV-101 }\end{array}$ & Cerdo y pollo & Fujita et al., 1988 \\
\hline $\mathrm{XO}, \mathrm{NP \text {yNT}}$ & $\begin{array}{l}\text { Amperométrico. Electrodo de } \\
\text { Platino vs. Ag/AgCl, } 0.7 \mathrm{~V}\end{array}$ & $\begin{array}{l}\text { Valor } \mathrm{K}, \\
\text { valor } \mathrm{H}, \mathrm{Hx}\end{array}$ & $\begin{array}{l}\text { En membrana preactivada de nylon } \\
\text { (XO y NP) y sobre la pared de un tubo } \\
\text { de poliestireno (NT) activado con } \\
\text { glutaraldehído }\end{array}$ & Trucha y bacalao & Loung y Male, 1992 \\
\hline $\mathrm{XO}, \mathrm{NP}, \mathrm{NT}$ & $\begin{array}{l}\text { Amperométrico. Electrodo de } \\
\text { polipirrol con mediador }\end{array}$ & $\begin{array}{l}\text { Valor } \mathrm{K}_{1} \\
\text { valor } \mathrm{H}\end{array}$ & $\begin{array}{l}\text { Sobre un electrodo recubierto de } \\
\text { polímero (polipirrol) y glutaraldehído, } \\
\text { mediador y BSA }\end{array}$ & $\begin{array}{l}\text { Pescado de agua } \\
\text { dulce }\end{array}$ & Ghosh et al., 1998 \\
\hline $\mathrm{XO}, \mathrm{NP}, \mathrm{NT}$ & $\begin{array}{l}\text { Amperométrico. Sistema de tres } \\
\text { reactores y electrodo de oxígeno }\end{array}$ & $\begin{array}{l}\text { Valor } \mathrm{K}_{1,} \\
\text { valor } \mathrm{H}\end{array}$ & $\begin{array}{l}\text { En perlas porosas de quitosano } \\
\text { activadas con glutaraldehído }\end{array}$ & Pescado & Park y Kim, 1999 \\
\hline $\mathrm{XO}, \mathrm{NP}, \mathrm{NT}$ & $\begin{array}{l}\text { Amperométrico. Sistema de tres } \\
\text { reactores y electrodo de oxígeno }\end{array}$ & $\begin{array}{l}\text { Valor } \mathrm{K}_{1,} \\
\text { valor } \mathrm{H}\end{array}$ & $\begin{array}{l}\text { En perlas porosas de quitosano } \\
\text { activadas con glutaraldehído }\end{array}$ & $\begin{array}{l}\text { Lomo de ternera y } \\
\text { pollo }\end{array}$ & Park et al., 2000 \\
\hline
\end{tabular}

Nota: XO - Xantina oxidasa, NP - Nucleosida fosforilasa, NT - 5'-nucleotidasa, ALF - Fosfatasa alcalina, AD - Adenosina deaminasa, U - Uricasa 
Tabla 6. Sensores enzimáticos utilizados para determinar hipoxantina en pescado y carne.

\begin{tabular}{|c|c|c|c|c|c|}
\hline Enzima & Transductor & Inmovilización & Pescado & $\begin{array}{l}\text { Rango de } \\
\text { detección }\end{array}$ & Referencia \\
\hline $\mathrm{xO}$ & $\begin{array}{l}\text { Amperométrico. Electrodo de } \\
\text { oxígeno }\end{array}$ & $\begin{array}{l}\text { En membrana de triacetato } \\
\text { del celulosa con } 1,8 \text { amino-4- } \\
\text { aminometiloctano activada } \\
\text { con glutaraldehído }\end{array}$ & $\begin{array}{l}\text { Atún, dorada, } \\
\text { cola amarilla }\end{array}$ & $0.06-1.5 \mathrm{mM}$ & Watanabe et al., 1983 \\
\hline $\mathrm{XO}$ & $\begin{array}{l}\text { Amperométrico. Electrodo de } \\
\text { platino vs. } \mathrm{Ag} / \mathrm{AgCl}, 0.7 \mathrm{~V}\end{array}$ & $\begin{array}{l}\text { En membrana de nylon } \\
\text { preactivada y glutaraldehído }\end{array}$ & $\begin{array}{l}\text { Trucha, carpa, } \\
\text { merluza, } \\
\text { lenguado }\end{array}$ & $3.6-107 \mu \mathrm{M}$ & Mulchandani et al., 1989 \\
\hline XO & $\begin{array}{l}\text { Amperométrico. Electrodo de } \\
\text { platino vs. } \mathrm{Ag} / \mathrm{AgCl}, 0.65 \mathrm{~V}\end{array}$ & $\begin{array}{l}\text { En membrana de seda y } \\
\text { glutaraldehído }\end{array}$ & Pescado & $0-100 \mu \mathrm{M}$ & Shen et al. , 1996 \\
\hline$N P, X O$ & $\begin{array}{l}\text { Amperométrico. Electrodo } \\
\text { químico modificado (carbono } \\
\text { vitrificado con Nafion), ciclo } \\
0.05 \text { a-0. }\end{array}$ & $\begin{array}{l}\text { En electrodo de carbono } \\
\text { vitrificado modificado con } \\
\text { película de Nafion }\end{array}$ & Pescado & $1-200 \mu \mathrm{M}$ & Hu y Liu, 1997 \\
\hline $\mathrm{xO}$ & $\begin{array}{l}\text { Amperométrico. Electrodo } \\
\text { químico modificado } \\
\text { (membrana de fibroína de seda } \\
\text { y acetato de celulosa) }\end{array}$ & $\begin{array}{l}\text { En membrana de fibroína de } \\
\text { seda activada con } \\
\text { glutaraldehído }\end{array}$ & Pescado de río & $0.1-10 \mu \mathrm{M}$ & Quiong et al., 1998 \\
\hline $\mathrm{XO}-\mathrm{HRP}$ & $\begin{array}{l}\text { Amperométrico. } \\
\text { composite blectrodo } \\
\text { (grafito-Teflón) con mediador } \\
\text { ferroceno, } 0.00 \mathrm{~V}\end{array}$ & $\begin{array}{l}\text { En la matriz del electrodo } \\
\text { composite con mediador } \\
\text { ferroceno }\end{array}$ & Sardina & $0.5-10 \mu \mathrm{M}$ & Cayuela et al. , 1998 \\
\hline $\mathrm{xO}$ & $\begin{array}{l}\text { Amperométrico. Electrodo } \\
\text { químico modificado (pasta de } \\
\text { carbono vitrificado con } \\
\text { polianilina), ciclo } 0.05 \text { a }-0.9 \mathrm{~V}\end{array}$ & $\begin{array}{l}\text { Sobre el electrodo químico } \\
\text { modificado con película de } \\
\text { polianilina por } \\
\text { electropolimerización }\end{array}$ & Pescado & $1-400 \mu \mathrm{M}$ & Hu et al., 2000 \\
\hline Xo & $\begin{array}{l}\text { Amperométrico, electrodo de } \\
\text { platino con película de nafion } \\
\mathrm{vs} . \mathrm{Ag} / \mathrm{AgCl}, 0.6 \mathrm{~V}\end{array}$ & $\begin{array}{l}\text { Sobre un electrodo de platino } \\
\text { cubierto con una película } \\
\text { nafion y cross-linking con } \\
\text { glutaraldehído y BSA }\end{array}$ & Pescado & $2-185 \mu \mathrm{M}$ & Nakatani et al ., 2005 \\
\hline Xo & $\begin{array}{l}\text { Amperométrico. Electrodo de } \\
\text { oxígeno }\end{array}$ & $\begin{array}{l}\text { En membrana polimérica } \\
\text { activada con glutaraldehído }\end{array}$ & Ternera & $0.1-1.2 \mathrm{mM}$ & Yano et al ., 1995a \\
\hline $\begin{array}{l}\mathrm{XO}, \mathrm{NP}, \\
\mathrm{NT}\end{array}$ & $\begin{array}{l}\text { Amperométrico. Electrodo de } \\
\text { oxígeno }\end{array}$ & $\begin{array}{l}\text { En columna con perlas de } \\
\text { silica activadas con } \\
\text { glutaraldehído }\end{array}$ & Ternera & $0.03-1.8 \mathrm{mM}$ & Numata et al., 1996 \\
\hline $\mathrm{xO}$ & $\begin{array}{l}\text { Amperométrico. Electrodo } \\
\text { pasta de carbono vs. } \mathrm{Ag} / \mathrm{AgCl}\end{array}$ & $\begin{array}{l}\text { En electrodo de pasta de } \\
\text { carbón con nanocristales de } \\
\text { oro }\end{array}$ & Sardina y pollo & --- & Agüi et al ., 2006 \\
\hline
\end{tabular}

Nota: XO-Xantina oxidasa, NP-Nucleosida fosforilasa, HRP - Peroxidasa

En el mismo contexto, se han desarrollado diversos sensores enzimáticos para la determinación de diferentes aminas biógenas. En la tabla 7 se recogen los sensores enzimáticos encontrados en la bibliografía que han sido aplicados a muestras reales de pescado y carne, describiendo de manera general el tipo de transductor, el procedimiento de inmovilización empleado, así como algunas características 
analíticas obtenidas. Estos sensores se basan en la reacción de oxidación de las $A B$ catalizada por diversas enzimas tales como la amina oxidasa, diamina oxidasa, putrescina oxidasa, tiramina oxidasa, utilizando una diversidad de métodos de inmovilización. La importancia de estos sensores radica en el tipo de enzima utilizada, ya que estas no son específicas para un solo analito. Algunas investigaciones han mostrado que dependiendo de la fuente de extracción (semillas de guisantes, garbanzo o de origen microbiano) y de la metodología de purificación, la enzima presentará mayor o menor actividad por algunas de las aminas biógenas como se muestra en la tabla 8 (Draici et al., 1998; Carsol y Mascini, 1999; Lange et al., 2002; Frebort et al., 2000, Niculescu et al., 2000), siendo esto una característica importante en la elección de la enzima para la construcción de dichos sensores.

Finalmente, cabe destacar que en los últimos años se han realizado grandes progresos en el desarrollo de biosensores, especialmente en la microelectrónica, la micro fabricación y el desarrollo de nuevos materiales para miniaturizar los sensores enzimáticos. Sin embargo, su aplicación al campo de la industria alimentaria así como su comercialización a gran escala es un reto aún pendiente. La industria alimentaria presenta una serie de características entre ellas la diversa composición química de los alimentos así como los diversos procesos y variaciones físicas a las que son sometidos, todas estas características suponen un reto a la hora de desarrollar biosensores. 
Tabla 7. Sensores enzimáticos para la determinación de aminas biógenas en pescado y carne.

\begin{tabular}{|c|c|c|c|c|c|c|}
\hline Enzima & Transductor & Inmovilización & Parámetro & Matriz & Rango de detección & Referencia \\
\hline PUO (Microccccus rubens) & $\begin{array}{l}\text { Electrodo serigrafiado de } \\
\text { platino vs } \mathrm{Ag} / \mathrm{AgCl}, 0.6 \mathrm{~V}\end{array}$ & 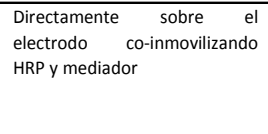 & $\begin{array}{c}\mathrm{PU}, \mathrm{CA}, \mathrm{SD} \\
\mathrm{AG}, \mathrm{TY}\end{array}$ & Abadejo & $\begin{array}{c}0.06-200 \mu \mathrm{M}(\mathrm{PU}), \\
0.1 \text { a } 14 \mu \mathrm{M}(\mathrm{CA}), \\
0.1 \text { a } 20 \mu \mathrm{M}(\mathrm{SD}), \\
1.5 \text { a } 40 \mu \mathrm{M}(\mathrm{AG}), \\
0.1 \text { a } 6 \mu \mathrm{M} \text { (TY) }\end{array}$ & Chemnitius, 1992 \\
\hline PUO (Microccccus rubens) & $\begin{array}{l}\text { Freshness meter KV-101, } \\
\text { sensor de oxigeno }\end{array}$ & Enzima libre en disolución & $\mathrm{PU}, \mathrm{CA}, \mathrm{SD}$ & Caballa & $10-70 \mu \mathrm{M}$ & Todoriki et al., 1988 \\
\hline $\begin{array}{l}\text { MAO (Aspergillus niger), } \\
\text { PUO (Microccccus rubens) }\end{array}$ & $\begin{array}{l}\text { Electrodo serigrafiado de } \\
\text { platino vs } \mathrm{Ag} / \mathrm{AgCl}, 0.6 \mathrm{~V}\end{array}$ & $\begin{array}{ll}\text { Electrodos silanizados } & \text { por } \\
\text { cross-linking } & \text { con } \\
\text { glutaraldehído } & \end{array}$ & $\begin{array}{c}\text { PU, CA, SD, } \\
\text { AG, TY }\end{array}$ & Bacalao, Caballa & $\begin{array}{c}0.06-200 \mu \mathrm{M}(\mathrm{PU}), \\
0.1 \text { a } 14 \mu \mathrm{M} \text { (CA), } \\
0.1 \text { a } 20 \mu \mathrm{M} \text { (SD), } \\
1.5 \text { a } 40 \mu \mathrm{M}(\mathrm{AG}), \\
0.1 \text { a } 6 \mu \mathrm{M} \text { (TY) }\end{array}$ & Chemnitius y Bilitewski, 1996 \\
\hline $\begin{array}{l}\text { DAO (Cicer arietinum y riñón } \\
\text { de cerdo) }\end{array}$ & $\begin{array}{l}\text { Amperométrico. Sensor } \\
\text { de platino vs } \mathrm{Ag} / \mathrm{AgCl} \text {, } \\
0.70 \mathrm{~V}\end{array}$ & $\begin{array}{l}\text { 1. En membrana de acetato de } \\
\text { celulosa y glutaraldehído sobre } \\
\text { el electrodo de platino, } 2 \text {. en } \\
\text { un reactor con perlas de vidrio } \\
\text { activadas con glutaraldehído, } \\
\text { 3. en un reactor co- } \\
\text { inmovilizando DAO-HRP y un } \\
\text { mediador }\end{array}$ & CA, PU. HI & Pescado & $0-100 \mu \mathrm{M}$ & Tombelli y Mascini., 1998 \\
\hline DAO (Riñón de cerdo) & $\begin{array}{l}\text { Electrodo de platino vs } \\
\mathrm{Ag} / \mathrm{AgCl}, 0.70 \mathrm{~V}\end{array}$ & $\begin{array}{l}\text { En una membrana preactivada } \\
\text { de nylon por cross-linking con } \\
\text { glutaraldehído }\end{array}$ & CA, PU. HI & Bacalao, Caballa & $25 \mu \mathrm{M}-6.0 \mathrm{mM}$ & Bouvrette et al., 1997 \\
\hline DAO (Plántula de garbanzo) & $\begin{array}{l}\text { Amperométrico. } \\
\text { Electrodo de platino vs } \\
\mathrm{Ag} / \mathrm{AgCl}, 650 \mathrm{mV}\end{array}$ & $\begin{array}{l}\text { En membranas de nylon } \\
\text { activadas con glutaraldehído }\end{array}$ & $\begin{array}{l}\text { PU, CA, HI, } \\
\text { SM, TY, SD, } \\
\text { TRY }\end{array}$ & Anchoas saladas & $1-50 \mu \mathrm{M}$ & Draisci et al ., 1998 \\
\hline PYO-OD & $\begin{array}{l}\text { Amperometrico. Sensor } \\
\text { de oxígeno }\end{array}$ & $\begin{array}{l}\text { En membrana de triacetato del } \\
\text { celulosa con } 1,8 \text { amino-4- } \\
\text { aminometiloctano activadas } \\
\text { con glutaraldehído }\end{array}$ & oc & Mariscos & $0-40 \mathrm{mM}$ & Shin et al ., 1998 \\
\hline $\begin{array}{l}\text { DAO (rinon de porcino), PUO } \\
\text { (Microccccus roseus), DAO } \\
\text { (lentejas) }\end{array}$ & $\begin{array}{l}\text { Electrodo de platino vs } \\
\mathrm{Ag} / \mathrm{AgCl} \text { en un reactor } \\
\text { acoplado a FIA }\end{array}$ & $\begin{array}{l}\text { Perlas de vidrio poroso } \\
\text { activadas con glutaraldehído }\end{array}$ & $\begin{array}{l}\mathrm{HI}, \mathrm{AG}, \mathrm{PU} \\
\mathrm{CA}, \mathrm{TY}, \mathrm{SM} \\
\mathrm{TRY}, \mathrm{SD}\end{array}$ & $\begin{array}{l}\text { Caballa, salmon, } \\
\text { atun, salami, } \\
\text { embutidos, } \\
\text { queso } \\
\text { parmesano, } \\
\text { queso pecorino }\end{array}$ & $\begin{array}{c}0.5-60 \mu \mathrm{M} \\
(\mathrm{DAO}) ; 0.07-500 \\
\mu \mathrm{M}(\mathrm{PU})\end{array}$ & Carsol y Mascini, 1999 \\
\hline$A O-H R P$ & $\begin{array}{l}\text { Electrodo de grafito con } \\
\mathrm{AO} \text { y HRP a }-50 \mathrm{mV} \text { vs. } \\
\mathrm{Ag} / \mathrm{AgCl} \text { entrecruzado con } \\
\text { polimero hidrogel } \\
\text { reductor }\end{array}$ & $\begin{array}{l}\text { En la matriz del electrodo de } \\
\text { grafito }\end{array}$ & $\begin{array}{l}\mathrm{HI}, \mathrm{PU}, \mathrm{CA}, \mathrm{TY}, \\
\mathrm{CY}, \mathrm{AG}, \mathrm{SD}\end{array}$ & Pescado & (-) & Niculescu et al., 2000 \\
\hline MAO (Aspergillus niger) & $\begin{array}{l}\text { Amperométrico. Sensor } \\
\text { de oxigeno }\end{array}$ & En membrana de colágeno & Monoaminas & $\begin{array}{l}\text { Pasta de carne } \\
\text { decerdo }\end{array}$ & - & Karube et al., 1980 \\
\hline TAO & $\begin{array}{l}\text { Amperométrico. } \\
\text { Electrodo de oxigeno en } \\
\text { reactor de columna }\end{array}$ & $\begin{array}{l}\text { En perlas porosas de vidrio } \\
\text { activadas con glutaraldehído }\end{array}$ & $\mathrm{TI}$ & $\begin{array}{l}\text { Solomillo de } \\
\text { ternera }\end{array}$ & $10-800 \mu \mathrm{M}$ & Yano et al., $1995 \mathrm{~b}$ \\
\hline $\mathrm{XO}, \mathrm{PUO}$ & $\begin{array}{l}\text { Amperometrico. } \\
\text { Electrodo de oxigeno }\end{array}$ & $\begin{array}{l}\text { Sobre una membrana } \\
\text { polimérica activada con } \\
\text { glutaraldehído }\end{array}$ & $\mathrm{H}, \mathrm{PU}$ & $\begin{array}{l}\text { Solomillo de } \\
\text { ternera }\end{array}$ & & Yano et al., 1996 \\
\hline $\begin{array}{l}\text { DAO (Cicer arietinum y riñón } \\
\text { de cerdo), TAO } \\
\text { (Arthrobacter spp), AO }\end{array}$ & $\begin{array}{l}\text { Electrodo serigrafiados de } \\
\text { platino vs } \mathrm{Ag} / \mathrm{AgCl}, 0.7 \mathrm{~V}\end{array}$ & $\begin{array}{l}\text { En el electrodo serigrafiados de } \\
\text { pelicula gruesa con } \\
\text { transglutaminasa } \\
\text { glutaraldehído }\end{array}$ & $\mathrm{HI}, \mathrm{TY}, \mathrm{PU}$ & $\begin{array}{l}\text { Productos } \\
\text { cárnicos, } \\
\text { cerveza, lácteos, } \\
\text { vino y alimentos } \\
\text { fermentados }\end{array}$ & 等- & Lange y Wittmann, 2002 \\
\hline
\end{tabular}

AO - Amina oxidasa, DAO - Diamina oxidasa, PUO - Putresina oxidasa, TAO - Tiramina oxidasa,HRP - Peroxidasa

PYO - Piruvato oxidasa, OD - Octamina deshidrogenasa, MAO- Monoamina oxidasa

HI - histamina, PU - putrescina, CA - cadaverina, TY - tiramina, CY - cistamina, AG - agmatina, SD - spermidina, OC - octopina 
Tabla 8. Selectividad de la enzima diamina oxidasa según su fuente de extracción.

\begin{tabular}{|c|c|c|c|c|c|c|c|c|}
\hline \multirow{2}{*}{ Enzima } & \multicolumn{8}{|c|}{ Aminas Biógenas/ Porcentaje de selectividad (\%) } \\
\hline & $\mathrm{HI}$ & $\mathrm{PU}$ & $\mathrm{CA}$ & TY & TR & AG & SD & SM \\
\hline DAO (Riñón de cerdo) ${ }^{1}$ & 100 & 28 & 14 & 1 & & 37 & $<1$ & $<1$ \\
\hline DAO (Lentejas) ${ }^{1}$ & 91 & & 100 & & & & & \\
\hline PUO (Micrococus roseus) ${ }^{1}$ & & 100 & 12 & 10 & 8 & 10 & 9 & \\
\hline DAO (Plántulas de garbanzo) ${ }^{2}$ & 98 & 100 & 100 & 73 & 30 & & 71 & 91 \\
\hline DAO $(\text { Cicer arietinum })^{3}$ & 2 & 100 & 2 & 8 & & $<1$ & 50 & 8 \\
\hline TAO (Arthrobacter spp) ${ }^{3}$ & $<1$ & $<1$ & $<1$ & 100 & & $<1$ & $<1$ & $<1$ \\
\hline $\mathrm{AO}^{3}$ & 100 & $<5$ & $<5$ & 90 & & $<1$ & 13 & $<5$ \\
\hline
\end{tabular}

DAO - Diamina oxidasa, PUO - Putresina oxidasa, TAO - Tiramina oxidasa, AO - Amina oxidasa

HI - Histamina, PU - Putresina, CA - Cadaverina, TY - Tiramina, SM - Espermina, TR - Triptamina, SD - Espermidina, AG - Agmatina

1. Carsol y Mascini, 1999

2. Draici et al ., 1998

3. Lange et al ., 2002 

2. Objetivos 



\section{Objetivos}

Los parámetros de calidad y seguridad alimentaria en la carne y los productos cárnicos curados son de gran importancia para los consumidores, por lo que la industria de la carne demanda métodos de análisis viables, rápidos, precisos, de bajo coste y lo más sencillos posibles. En este contexto, en la presente Tesis Doctoral se plantean dos objetivos principales:

1. Determinar la calidad y seguridad de la carne y productos cárnicos curados mediante cromatografía líquida de alta resolución.

Para la realización de este objetivo general se plantean los siguientes objetivos específicos:

- Evaluar la frescura de la carne durante el proceso de maduración mediante el análisis de nucleótidos y sus derivados por técnicas de IP-RPHPLC e HILIC.

- Evaluar el efecto de las sales de curado (nitrito y nitrato) sobre el contenido de nucleótidos y sus derivados y de aminas biógenas durante la fabricación de un embutido fermentado.

- Evaluar el efecto de tres formulaciones de salado sobre el contenido de nucleótidos y sus derivados y de aminas biógenas durante el proceso de curado del jamón. 
2. Desarrollar sensores enzimáticos de tipo amperométrico como técnicas rápidas de control de la calidad y seguridad de la carne y productos cárnicos curados.

Para la realización de este objetivo general se plantean los siguientes objetivos específicos:

- Desarrollar sensores enzimáticos para el análisis de la hipoxantina y aminas biógenas como indicadores de calidad y seguridad y la mejora de la inmovilización de las enzimas implicadas.

- Optimizar las condiciones de operación de los sensores enzimáticos para el análisis de hipoxantina y aminas biógenas.

- Correlacionar los resultados obtenidos con el sensor enzimático de hipoxantina y aminas biógenas y el método de referencia de cromatografía líquida.

- Aplicar el uso del sensor enzimático de hipoxantina como método de control de la maduración de la carne y de curado en embutidos fermentados y jamón.

- Aplicar el uso del sensor enzimático de aminas biógenas en productos curados (embutido fermentado y jamón) como método de control de seguridad. 
3. Plan de Trabajo 



\section{Plan de Trabajo}

Para cumplir con los objetivos propuestos en esta Tesis Doctoral se planteó la realización de las siguientes actividades:

1) Obtención de las muestras cárnicas bajo el siguiente esquema de control, en el que se muestran los productos objeto de estudio y las respectivas etapas de muestreo:

Carne Fresca
(Longissimus dorsi)


2) Puesta a punto del sensor enzimático con la enzima xantina oxidasa (XO) para la determinación de hipoxantina $(\mathrm{Hx})$.

- Examinar el comportamiento electroquímico del oxímetro en combinación con la enzima XO utilizando un sistema con la enzima libre y/o un sistema con la enzima inmovilizada.

- Optimización del método de inmovilización de la enzima XO.

- Optimización de las condiciones de operación del sensor ( $\mathrm{pH}$, temperatura) y su comprobación en términos de sensibilidad, repetibilidad, reproducibilidad recuperación y estabilidad.

- Evaluación del desarrollo de la reacción enzimática (XO-Hx) con la enzima libre en el sensor enzimático y analizado por HPLC.

3) Puesta a punto del sensor enzimático con la enzima diamina oxidasa (DAO) para la determinación de aminas biógenas (AB).

- Examinar el comportamiento electroquímico del oxímetro en combinación con la enzima DAO utilizando un sistema con la enzima inmovilizada.

- Optimización del método de inmovilización de la enzima DAO.

- Optimización de las condiciones de operación del sensor pH, selectividad, reproducibilidad y estabilidad.

4) Estudio de la evolución de los nucleótidos y sus derivados analizados por HPLC en la carne y productos cárnicos.

- Análisis en la carne fresca por cromatografía líquida de alta resolución con par iónico (IP-RP-HPLC) y puesta a punto del método por cromatografía líquida de interacción hidrofílica (HILIC).

- Puesta a punta del método cromatográfico para productos cárnicos curados por cromatografía líquida en fase reversa (RP-HPLC). 
5) Estudio de la evolución de las aminas biógenas analizadas por cromatografía líquida de alta resolución en fase reversa con par iónico (IP-RP-HPLC) y derivatización post-columna en los productos cárnicos curados (embutido fermentado y jamón).

6) Aplicación del sensor enzimático para la determinación de Hx en la carne y los productos cárnicos curados y su correlación con los métodos cromatográficos.

7) Aplicación del sensor enzimático para la determinación de $A B$ en los productos cárnicos curados y su correlación con los métodos cromatográficos. 

4. Materiales y Métodos 



\section{Materiales y Métodos}

Para desarrollar los experimentos derivados del presente trabajo de investigación se utilizaron muestras de carne fresca de cerdo y de productos cárnicos curados (embutido fermentado y jamón curado). Los métodos de fabricación y/o la obtención de las muestras se llevaron acabo en la Planta Piloto del laboratorio de Ciencia de la Carne del Instituto de Agroquímica y Tecnología de Alimentos (I.A.T.A.). Asimismo, la materia prima seleccionada para ello se adquirió de una empresa cárnica de la zona de Valencia.

\subsection{Materiales}

\subsubsection{Materias Prima.}

Para la experiencia con carne fresca se seleccionó el músculo Longissimus dorsi de lomos de cerdo procedentes del cruce Landrance $x$ Duroc de cuatro meses de edad. Inmediatamente después del sacrificio de los animales se seleccionaron cinco lomos normales a fin de evitar la variabilidad en el contenido de nucleótidos y sus derivados de los músculos pálidos, blandos y exudativos (PSE) y oscuros, firmes y secos (DFD) (Batlle et al., 2000 y 2001). Cada lomo se cubrió con film de plástico para evitar su deshidratación y se colocaron en una cámara de refrigeración a $4{ }^{\circ} \mathrm{C}$ para su maduración y posterior muestreo.

En la fabricación del embutido fermentado curado se utilizó carne magra y grasa dorsal (tocino) de cerdo, las cuales se trocearon y se congelaron a $-20^{\circ} \mathrm{C}$ hasta su utilización.

Para la fabricación de jamón curado se seleccionaron cincuenta y cuatro jamones de cerdo del cruce Landrance $x$ Large White de seis meses de edad, con un peso medio de $10 \pm 1 \mathrm{Kg}$ y un $\mathrm{pH}$ comprendido entre 5.5 y 6.0. Al igual que en la carne 
fresca se eligieron jamones normales para reducir la variabilidad en el contenido de nucleótidos y sus derivados. Los jamones se congelaron en un túnel industrial a - 40 ${ }^{\circ} \mathrm{C}$ y se almacenaron a $-20{ }^{\circ} \mathrm{C}$ hasta su utilización. Para el proceso de salado de los jamones se adquirieron diferentes tipos de sal tales como el cloruro de sodio $(\mathrm{NaCl})$, cloruro de potasio $(\mathrm{KCl})$, cloruro de calcio $\left(\mathrm{CaCl}_{2}\right)$ y cloruro de magnesio $\left(\mathrm{MgCl}_{2}\right)$, de Quality Chemicals (Quality Chemicals S. L., Esparraguera, Barcelona, España).

Adicionalmente se adquirieron en el supermercado cuatro jamones curados comerciales, con tiempos de curado entre 12 y 18 meses.

\subsubsection{Reactivos químicos.}

a). Determinación de hipoxantina $(H x)$ con el sensor enzimático.

Para desarrollar y operar el sensor enzimático se utilizó la enzima xantina oxidasa (XO, EC.1.2.3.2.) de leche de bovino con una actividad enzimática de $1.3 \mathrm{U} / \mathrm{mg}$ de proteína, glutaraldehído (50 \%), cisteína, acetato de celulosa, patrones de hipoxantina $(\mathrm{HX})$, xantina $(\mathrm{X})$ y ácido úrico $(\mathrm{AU})$ que fueron adquiridos de Sigma Aldrich (St. Louis, MO, USA), y ácido perclórico, carbonato de potasio y acetona de Scharlau (Scharlau Chemie, S.A., Barcelona, España). Las sales para preparar la disolución de trabajo, tampón fosfato sódico $\left(\mathrm{NaH}_{2} \mathrm{PO}_{4}\right.$ y $\left.\mathrm{Na}_{2} \mathrm{HPO}_{4}\right)$, fueron adquiridas de Panreac (Panreac Química, S.A, Barcelona, España).

Otros materiales requeridos en la preparación de este sensor fue la membrana preactivada Immunodyne $A B C$ (Nylon 66, con un tamaño de poro de $0.45 \mu \mathrm{m}$ ) que se suministró de Pall Europe (Porsmounth, United Kingdom) y la membrana de Teflón $(12.7 \mu \mathrm{m})$ permeable al oxígeno de Thermo Fisher Scientific Inc. (Madrid, España). 
b). Determinación de aminas biógenas con el sensor enzimático.

Para desarrollar y operar este sensor se utilizó la enzima comercial diamina oxidasa (DAO, EC.1.4.3.6.) de riñón de cerdo con una actividad enzimática de 0.18 $\mathrm{U} / \mathrm{mg}$ de sólido, glutaraldehído (50\%), glicina y patrones de histamina (HI), cadaverina (CA), putrescina (PU) tiramina (TY), espermina (SM) y espermidina (SD), los cuales se adquirieron de Sigma Aldrich (St. Louis, MO, U.S.A.). Las membranas y las sales para preparar las disoluciones de trabajo fueron las mismas a las utilizadas en el sensor de xantina oxidasa. Adicionalmente, se requirió de filtros de corte molecular de 100,000 Da con membrana de polietersulfona (Biomax-PB) y dispositivo para centrifugación (Ultrafree-CL) adquiridos de Millipore Corporation (Bedford, MA, U.S.A).

\section{c). Determinación de nucleótidos y sus derivados por cromatografía.}

Los reactivos químicos utilizados en la preparación de la fase móvil de las distintas técnicas cromatográficas fueron los disolventes acetonitrilo y metanol, supergradiente de grado HPLC, acetato de amonio, ácido acético glacial, ácido perclórico y carbonato de potasio que fueron adquiridos de Scharlau (Sharlau Chemie, S.A., Barcelona, España). Las sales para el tampón fosfato potásico $\left(\mathrm{KH}_{2} \mathrm{PO} 4\right.$ y $\mathrm{K}_{2} \mathrm{HPO} 4$ ) y el hidróxido de potasio de Panreac (Panreac Química, S.A, Barcelona, España). El par iónico $\mathrm{PIC}^{\circledR} \mathrm{A}$ (Bisulfato de tetrabutilamonio) se suministró de Waters (Water Corporation, Milford, MA, USA) y los patrones de adenosín trifosfato (ATP), adenosín difosfato (ADP), adenosín monofosfato (AMP), inosina 5' monofosfato (IMP), inosina (Ino), $\mathrm{Hx}, \mathrm{X}, \mathrm{AU}$, dinucleótido de nicotinamida adenina (NAD+), guanosina $(G)$ y uridina $(U)$, creatinina $(C n)$, guanosín monofosfato $(G M P)$, guanosín difosfato (GDP) y guanosín trifosfato (GTP) se obtuvieron de Sigma Aldrich (St. Louis, MO, USA). 


\section{d). Determinación de aminas biógenas por cromatografía.}

En el análisis de las aminas biógenas por cromatografía se utilizaron los mismos disolventes del apartado anterior y además, ácido perclórico, 2-mercaptoetanol y carbonato de potasio que se adquirieron en Scharlau (Sharlau Chemie, S.A., Barcelona, España). El acetato de sodio, el ácido bórico, el ácido acético glacial, el hidróxido de potasio, el detergente Brij-35 (éter polioxietilenlaurilico) al $30 \%$ en Panreac (Panreac Química, S.A, Barcelona, España) y los patrones HI, CA, PU, TR, SD, $S M$, serotonina (SE), octopamina (OC), dopamina (DO), agmatina (AG), $\beta$ feniletilamina (PHE), triptamina (TR), el orto-ftalaldehído (OPA) y el par iónico (octanosulfonato sódico) se adquirieron de Sigma Aldrich (St. Louis, MO, USA).

El agua empleada en todos los análisis fue bidestilada calidad Milli-Q (Millipore, Milli-Q Plus, Billerica MA, U.S.A).

\subsubsection{Instrumentación.}

Para la construcción del sensor enzimático, se utilizó un Oxímetro Modelo 20 de Rank Brothers Ltd (Bottisham, Cambridge, England) equipado con un registrador ADC-16 conectado a un ordenador provisto con el programa Pico Log (Pico Technology Limited, St. Netos, Cambridgeshire, United Kingdom). El oxímetro consta de un electrodo de oxígeno constituido a su vez de un disco central de platino (cátodo) de $2 \mathrm{~mm}$ de diámetro y un anillo de plata (ánodo), una cámara de incubación que puede ser acoplada a un baño maría para controlar la temperatura de reacción, una celda de reacción con una capacidad de $2.5 \mathrm{~mL}$, un sistema de agitación y un controlador que exhibe la corriente en porcentaje de saturación de oxígeno (\% saturación) y/o en mg de oxígeno/L (Figura 13). 

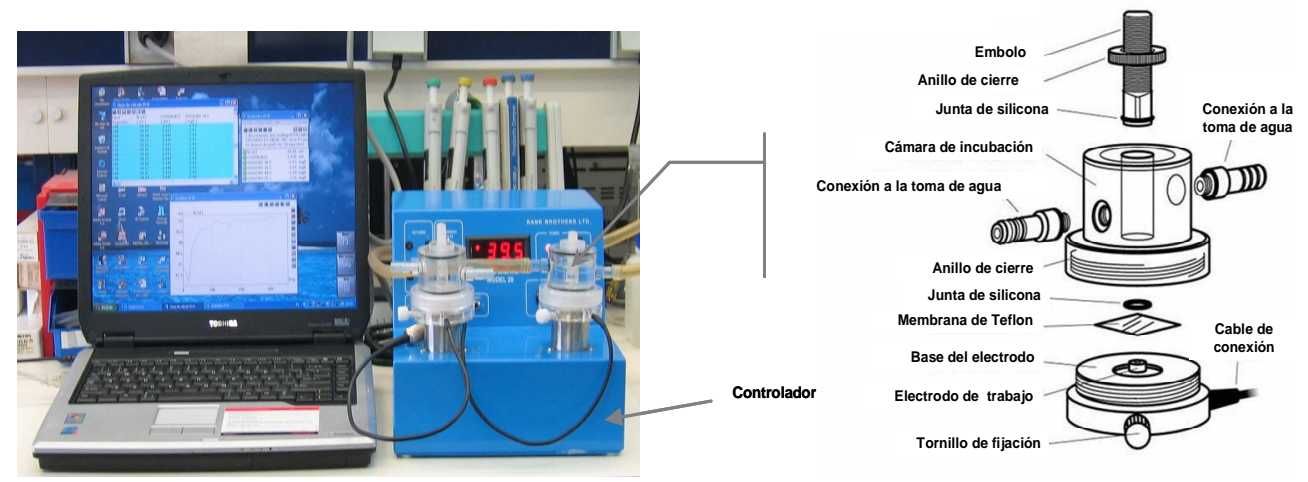

Figura 13. Esquema del Oximetro Mod. 20 Rank Brothers Ltd (Bottisham, Cambridge, England)

Como método de referencia y validación del sensor enzimático, se recurrió a la cromatografía líquida de alta resolución (HPLC), utilizando un cromatógrafo Agilent modelo 1100 (Agilent Technologies, Palo Alto, CA, USA), equipado con un autoinyector, un sistema de bombeo cuaternario, un compartimiento de columna termostatizado, un sistema de desgasificado a vacío y un detector de diodos en un intervalo de 195 - $300 \mathrm{~nm}$ para la detección ultravioleta de los nucleótidos y sus derivados. Para la detección de aminas biógenas, al sistema HPLC se le acopló un detector de fluorescencia de alta sensibilidad en un intervalo de longitud de onda de excitación de 200 - 700 nm y de emisión de 280 - 900 nm, una bomba extra cuaternaria y un sistema de derivatización post-columna, equipado con un colector mezclador " $\mathrm{T}$ " seguido de un espiral de reacción (de $0.16 \mathrm{~mm}$ de diámetro interno y $20 \mathrm{~cm}$ de longitud).

\subsection{Métodos de fabricación, seguimiento y obtención de muestras.}

\subsubsection{Maduración de la carne.}

La carne fresca (Longissimus dorsi) que se almacenó en refrigeración a $4{ }^{\circ} \mathrm{C}$ (ver apartado 4.1.1.) para su maduración, se muestreó a las 5, 7, 9, 11, 27, 51 y 171 
horas post mortem. En cada muestreo se extrajeron pequeñas virutas de lomo que se congelaron inmediatamente por inmersión en nitrógeno líquido y se envasaron a vacío, a fin de evitar la degradación de los nucleótidos, sobretodo en las primeras horas post-mortem (Batlle et al., 2000 y 2001). Finalmente, las muestras se almacenaron $\mathrm{a}-80^{\circ} \mathrm{C}$, hasta su análisis.

A fin de caracterizar que los lomos de cerdo elegidos en efecto era músculos normales, se determinó el pH y las pérdidas por goteo (Drip loss) a las 24 horas postmortem $(n=5)$ por duplicado, siguiendo el criterio adaptado por Flores et al., 1999. La medida de $\mathrm{pH}$ se realizó con un pH-metro Hamilton (Bonaduz AG, Switzerland) en una disolución de $5 \mathrm{~g}$ de muestra triturada y homogenizada con $15 \mathrm{~mL}$ de agua bidestilada en un Polytron PT2100 (Kinematica, Inc., Switzerland). En tanto que las drip loss se determinaron cortando tres lonchas, aproximadamente $100 \mathrm{~g}$ de cada lomo, se pesaron en una balanza analítica, se introdujeron en una bolsa de polietileno y se mantuvieron suspendidas en una cámara a $4{ }^{\circ} \mathrm{C}$ durante 72 horas, cuidando que la bolsa permaneciera bien cerrada para evitar pérdidas de agua por evaporación, y/o que no ejerciera presión sobre la loncha para evitar un exudado extra. Las pérdidas por goteo se expresaron como el porcentaje de pérdida de peso de la muestra con respecto a su peso a las 24 horas post-mortem.

\subsubsection{Fabricación del embutido fermentado curado.}

El proceso de fabricación del embutido fermentado curado se llevó a cabo bajo un proceso de fermentación lenta, según lo descrito por Marco et al., (2006). La carne magra y la grasa dorsal congelada (ver sección 4.1.1.) fueron trituradas por separado en una máquina picadora con una placa de $10 \mathrm{~mm}$ de diámetro; posteriormente se mezclaron en una proporción 80/20, respectivamente, para formar una masa cárnica. Para fines de esta investigación la masa cárnica se dividió en dos lotes. Uno de ellos se destinó para la fabricación del embutido utilizando 
nitrito de sodio $\left(\mathrm{NaNO}_{2}\right)$, en la sal de curado, mientras que en el otro lote solo se utilizó nitrato de potasio $\left(\mathrm{KNO}_{3}\right)$. Cada lote se paso a una amasadora al vacío y se añadieron los ingredientes y aditivos en la fabricación, en la proporción mostrada en la Tabla 9.

Tabla 9. Ingredientes y aditivos usados en la fabricación del embutido fermentado curado.

\begin{tabular}{lc}
\hline Ingredientes y aditivos & $\begin{array}{c}\text { g/Kg de mezcla } \\
\text { cánica* }\end{array}$ \\
\hline Cloruro de sodio & 27.00 \\
Lactosa & 20.00 \\
Dextrina & 20.00 \\
Caseinato de sodio & 20.00 \\
Glucosa & 7.00 \\
Ascorbato & 0.50 \\
Nitrito de sodio & 0.15 (Lote 1$)$ \\
Nitrato de potasio & 0.30 (Lote 2) \\
Cultivo iniciador & 0.10 \\
\hline
\end{tabular}

* Carne magra (80 \%) y grasa de cerdo $(20 \%)$

El amasado se realizó mediante dos ciclos alternativos de 2 min cada uno, inoculándose a continuación con el cultivo comercial SP-318 (Danisco, Cultor, Madrid, España), previamente diluido en agua estéril, que contenía Lactobacillus sakei, Pediococcus pentosaceus, Staphylococcus xylosus y Staphylococcus carnosus, y repitiéndose la operación de amasado. La mezcla cárnica se embutió en tripas de colágeno (Fibra, S.A. Girona, España) de 75-80 mm de diámetro, formando piezas de embutido de $500 \mathrm{~g}$ aproximadamente. Los embutidos se dejaron reposar en una cámara de refrigeración a $3-5{ }^{\circ} \mathrm{C}$ durante 24 horas, a fin de que los ingredientes y aditivos agregados se distribuyeran uniformemente. Posteriormente se colgaron en una cámara de maduración donde se llevó a cabo el proceso de secado a una temperatura de $10{ }^{\circ} \mathrm{C}$ y una humedad relativa (H.R.) entre $75-85 \%$ durante 42 días con pérdidas de peso de alrededor del $40 \%$. Finalmente, los embutidos fueron envasados a vacío y se almacenaron a $4{ }^{\circ} \mathrm{C}$ hasta alcanzar 91 días. 
A lo largo del proceso de curado se extrajo muestra del centro de tres embutidos en las siguientes etapas: etapa inicial (0 días), etapa de fermentación (11 días), etapa de maduración (21 días), etapa final de curado (42 días), etapa de envasado (91 días), las cuales fueron definidas por su evolución del pH durante el proceso de curado. El pH se midió introduciendo un electrodo de punción FC200B (Hanna Instruments Inc., Hoonsocket, USA) en el centro del embutido.

El contenido de humedad de las muestras obtenidas se determinó según el método recomendado por la norma ISO (ISO R-1442, 1973), por deshidratación de las muestras a $110^{\circ} \mathrm{C}$ en una estufa a presión atmosférica hasta peso constante.

Así mismo, a lo largo del proceso se realizó el análisis microbiológico de las muestras obtenidas. $20 \mathrm{~g}$ de la muestra fue homogenizada con $180 \mathrm{ml}$ de agua de peptona (15g/litro) en un Masticador Lab-Blender 400 (Seward Medical, Londres, reino Unido) durante $1 \mathrm{~min}$, de la suspensión resultante se realizaron diluciones decimales sucesivas en agua de peptona. La población de bacterias lácticas (BAL) se determinó sembrando $1 \mathrm{~mL}$ de cada dilución en MSR Agar (Scharlau Chemie S.A., Barcelona, España) (66 g/L de agua) empleando la técnica de la doble capa para favorecer el crecimiento anaerobio. El recuento de estafilococos se realizó sembrando una alícuota de $0.1 \mathrm{~mL}$ de la dilución respectiva en Manitol Sal Agar (Scharlau Chemie S.A., Barcelona, España) en una proporción de $111 \mathrm{~g} / \mathrm{L}$ de agua por la técnica de siembra en superficie. Todas las placas se sembraron por duplicado y se incubaron a $30^{\circ} \mathrm{C}$ durante 3 días.

\subsubsection{Fabricación del jamón curado.}

El proceso de fabricación del jamón curado se realizó tal y como se lleva a cabo en la industria cárnica. Los jamones seleccionados (ver sección 4.1.1.) se descongelaron en una cámara de refrigeración a $3{ }^{\circ} \mathrm{C}$ durante 5 días. 
Posteriormente, se masajearon manualmente para eliminar los restos de sangre y los líquidos exudados durante la descongelación. Tres de los jamones se utilizaron para caracterizar la materia prima y los 51 jamones restantes se dividieron en tres lotes, uno de 15 y dos de 18. Antes del salado, la superficie magra de cada jamón se frotó con una mezcla de sales nitrificantes (100 ppm de nitrito de sodio y 200 ppm de nitrato de potásio) para el curado. A continuación cada lote fue salado con diferentes mezclas de sal tal como aparece en la Tabla 10. El primer lote con $100 \%$ de $\mathrm{NaCl}$ se utilizó como control.

Tabla 10. Tratamientos de salado propuestos en el estudio de nucleótidos y sus derivados y aminas biógenas en jamón curado.

\begin{tabular}{lccc}
\hline \multirow{2}{*}{ Sal (\%) } & \multicolumn{3}{c}{ Formulación } \\
\cline { 2 - 4 } & I & II & III \\
\hline Cloruro de sodio $(\mathrm{NaCl})$ & 100 & 50 & 55 \\
Cloruro de Potasio $(\mathrm{KCl})$ & & 50 & 25 \\
Cloruro de Calcio $\left(\mathrm{CaCl}_{2}\right)$ & & & 15 \\
Cloruro de Magnesio $\left(\mathrm{MgCl}_{2}\right)$ & & & 5 \\
\hline
\end{tabular}

Los jamones se colocaron de manera individual en bandejas de plástico, manteniéndose en la cámara de salado durante $11-12$ días a $4{ }^{\circ} \mathrm{C}$ y una humedad relativa entre 85 y $90 \%$. Transcurrido ese tiempo las piezas se cepillaron para quitar la sal restante de la superficie y se trasfirieron a la cámara de post-salado donde se llevó a cabo la homogeneización y penetración completa de la sal. La temperatura se mantuvo en un intervalo de $4-5{ }^{\circ} \mathrm{C}$ y una H.R. entre 75 y $85 \%$. Los jamones de la formulación I se mantuvieron en estas condiciones durante 50 días, tiempo normalmente empleado en la industria cárnica, mientras que los de las formulaciones II y III se mantuvieron durante 80 días. El incremento en el tiempo de post-salado en estas formulaciones se aplicó debido a la menor velocidad de penetración de las sales divalentes (Blesa et al., 2008). Después del post-salado, los jamones se trasladaron a una cámara de maduración manteniéndose durante un 
periodo de 11 meses hasta una pérdida de peso del $34 \%$. Para ello, durante esta etapa, la temperatura se incremento paulatinamente de 14 a $20^{\circ} \mathrm{C}$ y la H.R. se disminuyó hasta un $70 \%$.

Con el fin de observar la evolución en el contenido de nucleótidos y sus derivados y de las aminas biógenas a lo largo del proceso de curado en las diversas formulaciones de salado, se tomaron muestras a diferentes tiempos de maduración. Para ello, de las respectivas cámaras se extrajeron tres jamones de cada formulación a los 20,50 y 80 días de post-salado (este último muestreo solo para las formulaciones II y III) y a los 7, 9 y 11 meses de curado. En cada uno de estos jamones se cortó una loncha central y se extrajo el músculo semimembranosus, el cual se almacenó a - $20^{\circ} \mathrm{C}$ hasta su análisis. El músculo semimembranosus se eligió debido a que es el primer músculo que entra en contacto con la mezcla de sales y el efecto podría verse rápidamente.

Por otro lado, a fin de estudiar el efecto de la temperatura y tiempo sobre el contenido de $\mathrm{Hx}$ en la etapa final de curado se tomaron muestras del músculo semimembranosus del los jamones de 11 meses de curado de la formulación I. La muestra se cortó en lonchas de $4 \mathrm{~mm}$ de grosor, aproximadamente, que se envasaron al vacío y se sometieron a diferentes temperaturas $\left(2030,40\right.$ y $\left.70{ }^{\circ} \mathrm{C}\right)$ y tiempos (0, 20, 40 y $60 \mathrm{~min}$ ) en un baño de agua. Luego, las muestras se enfriaron en baño con hielo y se colocaron en refrigeración a $4{ }^{\circ} \mathrm{C}$ hasta su análisis.

El contenido de humedad en cada caso se determinó mediante la deshidratación de la muestra a peso constante en un analizador de humedad de calefacción halógena HB-43 (Mettler Toledo AG, Switzerland) a $175^{\circ} \mathrm{C}$. En tanto que el pH se evalúo directamente en una disolución de $2 \mathrm{~g}$ de muestra triturada y homogenizada con $5 \mathrm{~mL}$ de agua bi-destilada en un Polytron PT2100 (Kinematica, Inc., Switzerland). 


\subsection{Métodos analíticos.}

\subsubsection{Extracción de nucleótidos y sus derivados.}

La extracción de nucleótidos y sus derivados se realizó conforme al método descrito por Burns y Ke, (1985) con algunos cambios. Durante el proceso de extracción fue esencial mantener la cadena de frío $\left(4^{\circ} \mathrm{C}\right)$, a fin de detener las reacciones de degradación de los nucleótidos, sobretodo en las primeras horas postmortem. Las muestras congeladas de la carne fresca y de los productos curados (ver apartado 4.2.) se trituraron y $5 \mathrm{~g}$ de cada muestra se homogenizaron con $15 \mathrm{~mL}$ de ácido perclórico $0.6 \mathrm{M}$ (enfriado a $4{ }^{\circ} \mathrm{C}$ ) en un masticador (IUL Stomaker, Barcelona, España) en frío durante $4 \mathrm{~min}$ en el caso de la carne fresca y $10 \mathrm{~min}$ con los productos curados. El extracto se centrífugó durante 20 min a 10,000 x g en una centrífuga refrigerada Sorvall ${ }^{\circledR}$ RC-SB (Du Pont Instruments). El sobrenadante se filtró a través de lana de vidrio y $12 \mathrm{~mL}$ de esta disolución se neutralizaron con carbonato potásico $(450 \mathrm{mg})$, hasta alcanzar un intervalo de $\mathrm{pH}$ de 6.5 - 7.0. El extracto neutralizado se mantuvo en un baño con hielo durante 20-30 min para terminar de precipitar todo el carbonato potásico. El sobrenadante se almacenó a $20{ }^{\circ} \mathrm{C}$ hasta su análisis.

Previo a su análisis por HPLC y por el sensor enzimático, los extractos cárnicos se descongelaron y se centrifugaron en una microcentrífuga Microfuge ${ }^{\circledR} 22 \mathrm{R}$ (Beckman Coulter, Fullerton, CA U.S.A.) a 10,000 r.p.m. durante 5 min a $4{ }^{\circ} \mathrm{C}$. A los extractos cárnicos que se analizaron por cromatografía HILIC se les adicionó tres volúmenes de $\mathrm{ACN}$ y se centrifugaron durante $10 \mathrm{~min}$ a $4{ }^{\circ} \mathrm{C}$ antes de inyectar. Este proceso permitió desproteizar aún más el extracto y acondicionarlo a la fase móvil cromatográfica, mejorando con ello la forma de los picos. 
4.3.2. Determinación de nucleótidos y sus derivados por HPLC.

\subsubsection{Análisis en carne.}

4.3.2.1.1. Cromatografía en fase reversa con par iónico (IP-RP-HPLC).

Los nucleótidos y sus derivados en carne fresca se analizaron por HPLC según la metodología propuesta por Veciana-Nogués et al., (1997) y Batlle et al., (2001). El extracto cárnico (10 $\mu \mathrm{L}$ ) (ver sección 4.3.1) se inyectó en una columna Zorbax Eclipse XDB-C18 (150 x $4.6 \mathrm{~mm}, 5 \mu \mathrm{m})$ (Agilent Technologies, USA), acondicionada a una temperatura de $30{ }^{\circ} \mathrm{C}$. La separación cromatográfica se realizó utilizando los disolventes y el gradiente que se detalla en la Tabla 11, a un flujo de $1.0 \mathrm{ml} / \mathrm{min}$. Después de cada análisis, la columna se lavó con 100 \% de la fase B y se estabilizó durante $15 \mathrm{~min}$ en las condiciones iniciales antes de volver a inyectar. La detección de los compuestos se realizó a $254 \mathrm{~nm}$ obteniéndose a su vez los espectros entre 190 y 350 de cada uno de ellos para su identificación. La cuantificación se realizó mediante una recta de calibrado obtenida con patrones en las mismas condiciones de análisis, tal como se detalla más adelante.

Tabla 11. Condiciones de fase móvil y gradiente en el análisis de nucleótidos y sus derivados en carne fresca por IP-RP-HPLC.

\begin{tabular}{ccc}
\hline Tiempo & \multicolumn{2}{c}{ Fase móvil (\%) } \\
\cline { 2 - 3 }$(\mathbf{m i n})$ & A & B \\
\hline 0 & 100 & 0 \\
5 & 100 & 0 \\
25 & 0 & 100 \\
\hline A: $\mathrm{PIC}^{\oplus}$ A & $5 \mathrm{mM}$ en tampón fosfato de potasio \\
$100 \mathrm{mM}$ pH 6.0 ajustado con $\mathrm{KOH}$ \\
B: $75 \%$ fase A: $25 \%$ metanol
\end{tabular}

\subsection{Cromatografía de interacción hidrofílica (HILIC).}

La separación de los nucleótidos y sus derivados en carne fresca y productos cárnicos por cromatografía HILIC se realizó utilizando una columna ZIC ${ }^{\circledR}$-pHILIC (4.6 x $150 \mathrm{~mm}, 5 \mu \mathrm{m})$ junto con una precolumna ZIC ${ }^{\circledR}$-pHILIC $(2.1 \times 20 \mathrm{~mm}, 5 \mu \mathrm{m})$, ambas 
obtenidas de SeQuant (Sweden). El extracto cárnico (20 $\mu \mathrm{L})$ se inyectó en el sistema y se utilizaron los disolventes y las condiciones de separación que se muestran en la Tabla 12 , a un flujo de $0.5 \mathrm{~mL} / \mathrm{min}$ y una temperatura de $28{ }^{\circ} \mathrm{C}$. La columna se equilibró por 15 min en las condiciones iniciales antes de cada inyección. Todos los extractos cárnicos se filtraron previamente a través de filtros de nylon de $0.22 \mu \mathrm{m}$ (Millipore) de tamaño de poro. La detección de los compuestos se realizó a $254 \mathrm{~nm}$ y su identificación se llevó a cabo por comparación del tiempo de retención y del espectro con sus respectivos patrones. La cuantificación se realizó mediante una recta de calibrado como se detallará mas delante.

Tabla 12. Condición de fase móvil y gradiente en el análisis de nucleótidos y sus derivados en carne fresca por HILIC.

\begin{tabular}{ccccc}
\hline \multirow{2}{*}{$\begin{array}{c}\text { Tiempo } \\
\text { (min) }\end{array}$} & A & B & C & D \\
\cline { 2 - 5 } & 15 & 0 & 80 & 5 \\
0 & 0 & 25 & 70 & 5 \\
3 & 0 & 25 & 70 & 5 \\
15 & 0 & 50 & 40 & 10 \\
25 & 0 & 50 & 40 & 10 \\
35 & 0 & &
\end{tabular}

A: Acetato de amonio $150 \mathrm{mM}, \mathrm{pH} 3.5$

B: Acetato de amonio $100 \mathrm{mM}, \mathrm{pH} 7.0$

C: Acetonitrilo

D: Agua bidestilada

\section{Ensayos de validación del método}

a. Linealidad. La linealidad del método HILIC se evalúo obteniendo la recta de calibrado (por triplicado) resultante de correlacionar el área del pico cromatográfico (mAU*s) con la correspondiente concentración de cada analito. La recta de calibrado se calculó utilizando las áreas de los picos de seis concentraciones patrón en un intervalo de concertación previsto en las muestras de la carne de cerdo. 
b. Límite de detección (LD). El LD para cada uno de los analitos analizados en HILIC se baso en la relación señal/ruido de 3:1. La desviación estándar de la señal en la zona de tiempo en la que eluyen el analito se calculó tomando la señal media de 20 inyecciones de blanco (reactivos sin extracto cárnico) y los valores del LD obtenidos fueron confirmados analizando varias diluciones de un extracto cárnico de 5 horas post-mortem.

c. Repetibilidad. En el estudio de repetibilidad se inyectaron sucesivamente ocho extractos de carne de 5 horas post-morten, en las mismas condiciones y por el mismo analista para estimar la concentración media de cada analito y su desviación estándar.

d. Reproducibilidad. La reproductibilidad del método HILIC se probó en un mismo extracto de carne (5 horas post-mortem), el cual se dividió en ocho alícuota y se almaceno a - $20^{\circ} \mathrm{C}$ para su análisis en seis diversos días. Así, cada análisis se realizó por distintos operadores y sistemas HPLC.

e. Recuperación. La recuperación de todos los compuestos obtenidos se determinó adicionando cantidades conocidas de su patrón respectivo a un extracto cárnico de 5 horas post-mortem. Así, el extracto cárnico se enriqueció hasta alcanzar concentraciones equivalentes de $0.5,1.0$ y 1.5 veces los valores obtenidos en el estudio de reproducibilidad. En cada nivel de enriquecimiento, los análisis se realizaron por duplicado y la recuperación se calculó por comparación con una muestra no enriquecida.

\subsubsection{Análisis en productos curados.}

4.3.2.2.1. Cromatografía en fase reversa (RP-HPLC).

La determinación de nucleótidos y sus derivados en el caso de los productos curados se realizó por cromatografía en fase reversa utilizando una columna Synergi 
$\mathrm{C}_{18}$ MAX-RP 80A (150 x $4.6 \mathrm{~mm}, 5 \mu \mathrm{m}$ ) (Phenomenex, Torrance, CA, USA). El extracto cárnico $(10 \mu \mathrm{L})$ se inyectó en el sistema a un flujo de $0.8 \mathrm{~mL} / \mathrm{min}$ a $30{ }^{\circ} \mathrm{C}$. La composición de la fase móvil y el gradiente empleado en la separación se muestra en la Tabla 13. Después de cada inyección la columna se lavó con $60 \%$ de metanol durante 5 min y se equilibró 10 min bajo condiciones iniciales antes de la siguiente inyección. La detección de los compuestos se realizó a una longitud de onda de 270 nm para la xantina, 295 para el ácido úrico y $254 \mathrm{~nm}$ para el resto de los compuestos, su identificación se llevó a cabo por comparación del tiempo de retención y del espectro entre 190 y $350 \mathrm{~nm}$ con los de sus respectivos patrones. La cuantificación se realizó mediante una recta de calibrado.

Tabla 13. Condiciones de fase móvil y gradiente en el análisis de nucleótidos y sus derivados en productos curados por RP-HPLC.

\begin{tabular}{ccc}
\hline \multirow{2}{*}{$\begin{array}{c}\text { Tiempo } \\
(\mathbf{m i n})\end{array}$} & \multicolumn{2}{c}{ Fase móvil (\%) } \\
\cline { 2 - 3 } & A & B \\
\hline 0 & 100 & 0 \\
12 & 100 & 0 \\
25 & 80 & 20 \\
\hline A: Tampón fosfato potásico $50 \mathrm{mM} \mathrm{pH} 4.0$ \\
ajustado con $\mathrm{H}_{3} \mathrm{PO}_{4}$ \\
B: Metanol
\end{tabular}

\subsubsection{Rectas de calibrado.}

Para construir las rectas de calibrado en cada una de las técnicas cromatográficas, se preparó una disolución stock de los patrones de calibración (1 $\mathrm{mM}$ ) con el disolvente de la muestra (ácido perclórico $0.6 \mathrm{M}$ neutralizado con carbonato potásico a pH 6.5-7.0). Las disoluciones de trabajo se prepararon en un intervalo apropiado de concentraciones por dilución de la disolución stock con el mismo disolvente. En el caso de la cromatografía HILIC la disolución stock se preparó diluyendo el disolvente de la muestra con un volumen de $A C N$ (50:50) y las 
subsecuentes diluciones con una disolución ácido perclórico $0.6 \mathrm{M}$ neutralizado:ACN (50:50 v/v). Todas las disoluciones patrón se almacenaron a $-20^{\circ} \mathrm{C}$.

Finalmente, la fase móvil utilizada en cada una de las técnicas cromatográficas en el sistema HPLC, se filtró al vacío a través de un filtro de tamaño de poro de $45 \mu \mathrm{m}$ (Millipore) y se desgasificó en el ultrasonidos.

\subsubsection{Determinación de hipoxantina con el sensor enzimático.}

La medida amperométrica de la hipoxantina se llevó a cabo con un oxímetro, descrito en el apartado 4.1.3. y la enzima xantina oxidasa (libre o inmovilizada) lo que denominaremos, respectivamente, sistema enzimático con la enzima libre o un sistema enzimático con la enzima inmovilizada.

La calibración inicial del oxímetro se consiguió dejándolo estabilizar la corriente de entrada al controlador, conectándolo a la fuente de electricidad durante 15 min y ajustando posteriormente a cero. Sobre el electrodo de oxígeno, cátodo de platino y ánodo de plata, se colocó un pañuelo de papel $\left(1.5 \mathrm{~cm}^{2}\right.$ con un hueco de $2 \mathrm{~mm}$ en el centro) humedecido con un electrólito alcalino (cloruro de potasio $3 \mathrm{M}$ ) a fin de conseguir el puente eléctrico entre ellos y cerrar el circuito. Sobre este se colocó una membrana de Teflón $\left(1.5 \mathrm{~cm}^{2}\right)$ asegurando que el electrodo de platino estuviese en el centro y que no hubiese burbujas de aire atrapadas (Figura 14). Al sistema se le acopló la cámara de incubación y mediante una junta de silicona se sujetaron las membranas, como puede apreciarse en la figura 13. La cámara se conectó a un baño de agua y con recirculación forzada se controló la temperatura de reacción. Finalmente, el electrodo de oxígeno se conectó al controlador y el potencial de polarización se fijó a - $600 \mathrm{mV}$ con respecto al electrodo de referencia de $\mathrm{Ag} / \mathrm{AgCl}$. 


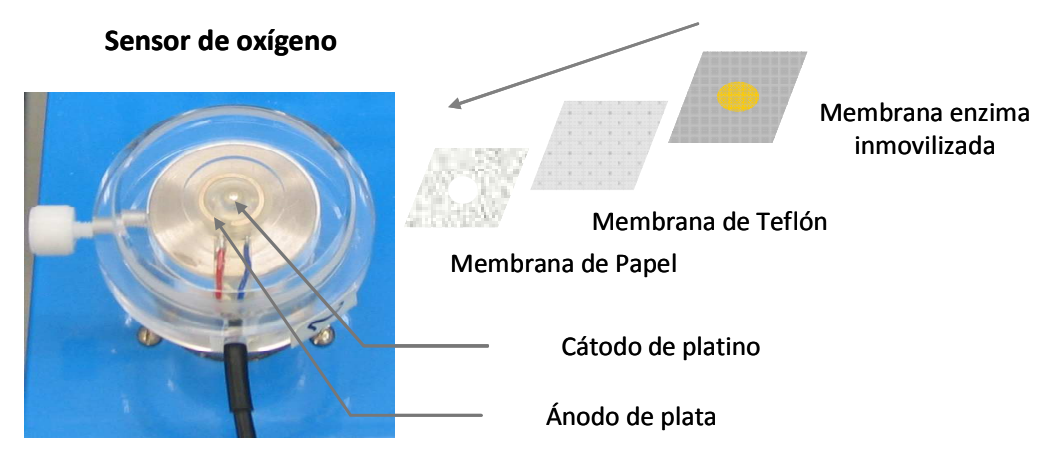

Figura 14. Esquema del montaje de las membranas en el sensor de oxígeno

La sensibilidad del equipo se ajustó llenado la celda de reacción con agua bidestilada saturada de oxígeno $(1 \mathrm{~mL})$ en condiciones de agitación hasta conseguir una lectura del $100 \%$ de saturación. Así, el potencial aplicado al oxímetro, específicamente al sensor de platino (cátodo), es un voltaje lo suficientemente negativo respecto al electrodo de plata (ánodo) para que todo el oxígeno que haya en la disolución en la celda de reacción difunda a través de la membrana de teflón, alcance el electrodo de platino y se reduzca (ecuación 13a y 13b), de modo que la corriente resultante que fluye entre los electrodos es proporcional a la presión parcial de oxígeno en el sistema, relación establecida por la Ley de difusión de Fick, (ecuación 13c). El controlador a su vez convierte ese voltaje directamente en una corriente que se exhibe en unidades de porcentaje de saturación y/o en mg de oxígeno/L, cuya transformación se realizó con antelación en el programa de registro de datos a la temperatura de análisis, utilizando las tablas de Colt J., (1984).

A continuación se establecieron las condiciones iniciales de funcionamiento para ambos sistemas enzimáticos. La diferencia en el sistema inmovilizado fue situar la membrana con la enzima inmovilizada sobre las membranas de papel y teflón, ya colocadas (Figura 14). 
(13)

Reacción en el cátodo

Reacción en el ánodo

$$
\begin{aligned}
\mathrm{O}_{2}+2 \mathrm{H}_{2} \mathrm{O}+4 e^{-} & \rightarrow 4 \mathrm{OH}^{-} \quad \text { (a) } \quad 4 \mathrm{Ag}+4 \mathrm{Cl}^{-} \rightarrow 4 \mathrm{AgCl}+4 e^{-} \text {(b) } \\
I & =4 \times F \times P_{m} \times A \times \frac{p \mathrm{O}_{2}}{b} \quad \text { (c) }
\end{aligned}
$$

donde: $I$, corriente del eléctrodo; $F$, constante de Faraday; $P_{m}$, permeabilidad del $\mathrm{O}_{2}$ en la membrana de Teflón; $\mathrm{A}$, área del cátodo; $b$, grosor de la membrana de Teflón; $\mathrm{pO}_{2}$, presión parcial del oxígeno en la disolución.

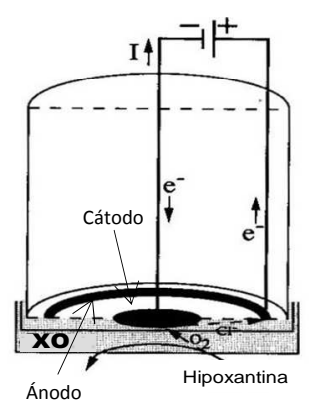

\subsubsection{Sistema enzimático con la enzima libre.}

Para determinar el contenido de hipoxantina en el sistema con la enzima libre, la celda de reacción (termostatizada a $30^{\circ} \mathrm{C}$ ) se llenó con $900 \mu \mathrm{L}$ de la disolución de reacción (tampón fosfato sódico $50 \mathrm{mM}$, pH 7.6) y se agitó suavemente con una varilla magnética hasta que la señal de oxígeno se mantuvo constante. Inmediatamente, se inyectó $10 \mu \mathrm{L}$ de una disolución enzimática, conteniendo $0.0169 \mathrm{U}$ de la enzima disuelta en tampón fosfato sódico $50 \mathrm{mM}, \mathrm{pH} 7.6$, y se mantuvo en agitación durante $45 \mathrm{~s}$ más a fin de homogenizar la enzima en la disolución de reacción. Posteriormente, se inyectó $100 \mu \mathrm{L}$ del extracto cárnico o del patrón de $\mathrm{Hx}$ (0 - $1 \mathrm{mM}$ ) y se registró el cambio del consumo de oxígeno durante la reacción enzimática hasta que la señal de respuesta se mantuvo constante. La acumulación del oxígeno (mg/L) a 190 s se extrapoló en una recta de calibrado de patrón de Hx obtenida en las mismas condiciones a diferentes concentraciones. La disolución patrón y las diluciones requeridas para la recta de calibrado se prepararon como se describió en el apartado 4.3.2.3.

Con este sistema se evaluó y se optimizó la operación del sensor enzimático. Para ello se realizaron algunas pruebas de reconocimiento del sistema, tales como: la monitorización del consumo de oxígeno durante la reacción enzimática a diferentes condiciones de $\mathrm{pH}(5.6,6.6,7.6$ y 8.6$)$, temperatura $\left(25,30,35\right.$ y $\left.40^{\circ} \mathrm{C}\right)$, 
concentración de sustrato y de enzima. Asimismo, debido a que la señal detectada en el sensor enzimático, corresponde al oxígeno consumido resultado del efecto catalítico de la xantina oxidasa sobre la hipoxantina y la xantina se determinó la cinética enzimática de la enzima, como se muestra a continuación.

\subsection{Evolución de la reacción enzimática.}

Veinte microlitros de una disolución patrón de hipoxantina $(1 \mathrm{mM})$ se inyectó en el sistema a diferentes temperaturas $\left(25,30,35\right.$ y $\left.40{ }^{\circ} \mathrm{C}\right)$. Durante la reacción enzimática se extrajo una alícuota de $30 \mu \mathrm{L}$ cada $10 \mathrm{~s}$ y se mezcló inmediatamente con un volumen igual de ácido perclórico (1 M) para detener la reacción. Posteriormente, la mezcla se neutralizó adicionando $2.25 \mathrm{mg}$ de carbonato potásico. El extracto neutralizado se centrifugó en una micro centrifuga a 10,000 r.p.m. durante $5 \mathrm{~min}$ a $4{ }^{\circ} \mathrm{C}$ y $30 \mu \mathrm{L}$ de las muestras obtenidas se inyectaron en el cromatógrafo por triplicado como se describe en el apartado 4.3.2.2.1 .

\subsubsection{Sistema enzimático con la enzima inmovilizada.}

\subsection{Inmovilización de la enzima xantina oxidasa.}

La inmovilización de la enzima xantina oxidasa se desarrolló con base en lo descrito por Watanabe et al., (1983), Mulchandani et al., (1990) y Luong y Male, (1992) con algunos cambios. La membrana de xantina oxidasa se preparó por entrecruzamiento o cross-linking de la enzima con glutaraldehído y su posterior unión covalente con la membrana preactivada Immunodyne ABC. De esta manera, una mezcla de $50 \mu \mathrm{L}$, conteniendo $15 \mu \mathrm{L}$ de la disolución enzimática con $0.50 \mathrm{U}$ de la enzima, $27 \mu \mathrm{L}$ del tampón fosfato sódico ( $50 \mathrm{mM}, \mathrm{pH} 7.6)$ y $8 \mu \mathrm{L}$ de una disolución de glutaraldehído al $12.5 \%$, se depositó gota a gota sobre la membrana preactivada $\left(1 \mathrm{~cm}^{2}\right)$. La membrana se secó al aire durante una 1 hora para iniciar el entrecruzamiento; posteriormente, se sumergió en una disolución de la cisteína $0.10 \mathrm{mM}$ durante $20 \mathrm{~min}$ a fin de estabilizar el proceso de inmovilización. Para 
eliminar el exceso de glutaraldehído, la membrana se lavó exhaustivamente con el tampón fosfato. Una vez escurrida y seca se añadió $5 \mu \mathrm{L}$ de una disolución de acetato de celulosa al 2 \% diluida en acetona, para evitar la contaminación de algunas formas de inclusión y de adsorción de proteínas del extracto de carne en la membrana (Qiong et al., 1998). Finalmente, la membrana se dejó secar al aire durante 5 min para evaporar el disolvente y se almacenó en el tampón fosfato sódico a $4{ }^{\circ} \mathrm{C}$ hasta su utilización.

Una vez se obtuvo la membrana con la enzima inmovilizada, $40 \mu \mathrm{L}$ del patrón de $\mathrm{Hx}$ a diferentes concentraciones o del extracto cárnico debidamente diluido en el disolvente de extracción se inyectó directamente sobre la membrana con una microjeringa de cristal Hamilton (Análisis Vinicos, Tomelloso, España). Así, el contenido de $\mathrm{Hx}$ en las muestras de carne y los productos cárnicos, se calculó a partir del consumo acumulado de oxígeno obteniendo la velocidad de reacción ( $\mathrm{mg}$ $\mathrm{O}^{2} / \mathrm{L}^{-1} \mathrm{~S}^{-1}$ y extrapolando el valor en una recta de calibrado de $\mathrm{Hx}$ obtenida en las mismas condiciones. Después de cada inyección, la membrana de XO se lavó tres veces con el tampón fosfato, se secó con un pañuelo de papel y se restauró el equilibrio del sistema con el oxígeno atmosférico durante 3 min antes de una nueva inyección. Cada tres inyecciones consecutivas de extracto de carne en ambos sistemas enzimáticos se utilizó una disolución del cloruro de sodio $(\mathrm{NaCl}) 125 \mathrm{mM}$ para el lavado del sistema y así, evitar futuros problemas de contaminación proteica (Luong y Male, 1992).

\subsubsection{Ensayos de validación del sensor enzimático.}

a. Linealidad. La linealidad en ambos sistemas enzimáticos, libre e inmovilizado, se obtuvo del análisis por triplicado de su respectiva recta de calibrado. Así, un intervalo de concentración (0 - $1 \mathrm{mM}$ ) del patrón de Hx se correlacionó con la señal 
obtenida en cada sensor. El ajuste de la recta se realizó utilizando el método de los mínimos cuadrados.

b. Repetibilidad. La medida de repetibilidad se determinó por inyección repetida de una misma concentración de $\mathrm{Hx}(1 \mathrm{mM})$ o de un extracto de carne de 7 horas post-mortem, los cuales se analizaron en el mismo día, con el mismo equipo y bajo las mismas condiciones de operación de cada sensor enzimático. La medida de la repetibilidad se calculó obteniendo el coeficiente de variación (\%).

c. Recuperación. Dos muestras de carne fresca de cerdo de 7 horas post-mortem se enriquecieron con $0.5,1.0$ y 1.5 veces la concentración natural de $\mathrm{Hx}$ respectivamente y se analizó en el sistema enzimático con la enzima inmovilizada, por cuadruplicado. El porcentaje de recuperación se calculó comparando la señal obtenida en la muestra no enriquecida con la obtenida para cada nivel de enriquecimiento.

d. Estabilidad. La estabilidad de la enzima xantina oxidasa se evalúo en ambos sensores enzimáticos. En el sistema con la enzima libre, cinco disoluciones enzimáticas conteniendo $0.0169 \mathrm{U}$ de la enzima en tampón fosfato sódico (50 mM, pH 7.4) se prepararon y se almacenaron a $4{ }^{\circ} \mathrm{C}$. Cada disolución enzimática se utilizó una semana, inyectando de manera sucesiva cuatro inyecciones de $20 \mu \mathrm{L}$ de $\mathrm{Hx}(1$ $\mathrm{mM}$ ) por día durante tres días para su evaluación. En el sistema con la enzima inmovilizada, se evalúo la estabilidad operacional de la membrana de XO y su estabilidad durante el almacenamiento a $4{ }^{\circ} \mathrm{C}$. En el primer de los casos se realizaron inyecciones sucesivas sobre la membrana con disoluciones patrón de $\mathrm{Hx}$ a lo largo del día (aproximadamente 30 inyecciones/día) durante tres días seguidos, almacenándose a $4{ }^{\circ} \mathrm{C}$ cuando no se utilizaba. En el segundo de los casos, seis membranas de XO se almacenaron en tampón fosfato sódico $(50 \mathrm{mM}, \mathrm{pH} 7.4)$ a $4{ }^{\circ} \mathrm{C}$ 
y su estabilidad se evaluó cada quince días, obteniendo su respectiva curva de calibración por duplicado.

Finalmente, el contenido de $\mathrm{Hx}$ obtenido en la carne y los productos cárnicos en ambos sistemas enzimáticos se correlacionaron con aquellos obtenidos por HPLC.

\subsubsection{Extracción de aminas biógenas.}

El proceso de extracción de la aminas biógenas ( $A B$ ) en las muestras de los productos cárnicos curados (embutido fermentado y jamón), fue similar al empleado para los nucleótidos y descrito en el apartado 4.3.1.

\subsubsection{Determinación de aminas biógenas en productos cárnicos curados por IP- RP-HPLC y derivatización post-columna.}

Las aminas biógenas se analizaron por cromatografía en fase reversa con par iónico y derivatización post-columna con orto-ftalaldehído (OPA) según el método propuesto por Hernández-Jover et al., (1996), utilizando una columna Nova Pak $C_{18}$ (3.9 × 150 mm, $4 \mu \mathrm{m}$ ) (Waters Cromatografía). La separación cromatográfica se llevó a cabo en gradiente entre dos disolventes tal como se muestra en la tabla 14 a un flujo de $1 \mathrm{~mL} / \mathrm{min}$. El eluyente de la columna se mezcló a través de una conexión en " $T$ " y una espiral de reacción (de $0.16 \mathrm{~mm}$ de diámetro interno y $20 \mathrm{~cm}$ de longitud) con el reactivo de derivatización que consistió en una disolución de ácido bórico $(31.0 \mathrm{~g} / \mathrm{L})$ e hidróxido de potasio $(26.0 \mathrm{~g} / \mathrm{L})$ en agua bidestilada, añadiendo $3 \mathrm{~mL} / \mathrm{L}$ de Brij-35 al $30 \%, 3 \mathrm{~mL} / \mathrm{L}$ de 2-mercaptoetanol y $200 \mathrm{mg} / \mathrm{L}$ de orto-ftalaldehído (OPA, previa disolución en $5 \mathrm{~mL}$ de metanol). Dicho reactivo se impulsó a 0.5 $\mathrm{mL} / \mathrm{min}$ por medio de una bomba de HPLC Agilent modelo 1050 (Agilent Technologies, Palo Alto, CA, USA) hasta la conexión en " $T$ " antes mencionada. La detección de las $A B$ se realizó con un detector de fluorescencia a una longitud de onda de excitación 340 nm y emisión 445 nm y su identificación se llevó a cabo por 
comparación del tiempo de retención con sus respectivos patrones. Tras el análisis, la columna se equilibró en condiciones iniciales durante 10 min antes de la siguiente inyección.

Tabla 14. Gradiente de fase móvil para el análisis de aminas biogénas por IP-RP-HPLC y derivatización post-columna.

\begin{tabular}{ccc}
\hline $\begin{array}{c}\text { Tiempo } \\
(\min )\end{array}$ & \multicolumn{2}{c}{ Fase móvil* (\%) } \\
\cline { 2 - 3 } & A & B \\
\hline 0 & 80 & 20 \\
45 & 20 & 80
\end{tabular}

Fase A: Octanosulfonato sódico $10 \mathrm{mM}$ en tampón acetato sódico $100 \mathrm{mM}, \mathrm{pH} 5.20$ ajustado con ácido acético glacial.

Fase B: $66 \%$ de octanosulfonato sódico $10 \mathrm{mM}$ en tampón acetato sódico $200 \mathrm{mM}$, pH 4.20 ajustado con ácido acético glacial, y $34 \%$ acetonitrilo

La cuantificación de las $A B$ se realizó empleando el área de los picos cromatográficos por interpolación en las correspondientes rectas de calibrado obtenidas con patrones de $A B$ en las mismas condiciones de análisis. Para construir las rectas de calibrado, se preparó una disolución madre $(1 \mathrm{mg} / \mathrm{mL})$ de cada uno de los patrones de las aminas ensayadas en el disolvente de extracción de las muestras (ácido perclórico $0.6 \mathrm{M}$ neutralizado con carbonato potásico a pH 6.5-7) a partir de la cual se prepararon las disoluciones de trabajo en el intervalo apropiado de concentraciones por dilución con el mismo disolvente. La dilución madre se conservó durante una semana a $-20^{\circ} \mathrm{C}$ y protegida de la luz.

\subsubsection{Determinación de aminas biógenas con el sensor enzimático.}

La determinación de las aminas biógenas se llevó acabo también en un sensor enzimático construido con un oxímetro (descrito en el apartado 4.1.3.) y la enzima comercial diamina oxidasa de riñón de cerdo (DAO, EC 1.4.3.6) inmovilizada en una membrana preactivada Immunodyne $A B C\left(1 \mathrm{~cm}^{2}\right)$. La calibración inicial del oxímetro 
y el ensamble de la membrana enzimática se realizó en condiciones similares a las descritas en el apartado 4.3.3.

\subsubsection{Inmovilización de la enzima diamina oxidasa.}

El proceso de inmovilización de la DAO se llevó a cabo mediante unión covalente de la enzima y entrecruzamiento con glutaraldehído a una membrana de nylon preactivada. Previo a la inmovilización, a fin de concentrar la enzima y limpiarla de impurezas, $1 \mathrm{~mL}$ de una disolución enzimática que contiene $110 \mathrm{mg}$ de DAO (0.18 $\mathrm{U} / \mathrm{mg}$ de sólido) en tampón fosfato sódico ( $100 \mathrm{mM}, \mathrm{pH} 7.2)$ se concentró dos veces, por centrifugación a 4470 r.p.m. durante $40 \mathrm{~min}$ a través de un filtro de corte molecular de 100,000 Da utilizando una centrifuga Medifringer BL-S (J. P. Selecta, Barcelona, España). Así, $5 \mu \mathrm{L}$ de la disolución enzimática concentrada se depositó sobre la membrana y se dejó secar durante $15 \mathrm{~min}$ al aire. A continuación, la membrana se sumergió cuidadosamente, del lado opuesto a donde se depositó la enzima, en una disolución de glutaraldehído al $1 \%$ durante $30 \mathrm{~s}$ e inmediatamente se lavó cinco veces con una disolución de glicina 100 mM (diluida en tampón fosfato sódico $100 \mathrm{mM}, \mathrm{pH}$ 7.2.) para estabilizar la inmovilización. La membrana se lavó exhaustivamente con el tampón fosfato sódico (100 mM, pH 7.2) antes de almacenarla en el mismo tampón a $4{ }^{\circ} \mathrm{C}$ hasta su utilización.

Obtenida la membrana enzimática, se montó en el sistema, como se observa en la figura 14, y se le aplicó un voltaje de $-600 \mathrm{mV}$ vs. Ag/Agul. Tras su estabilización a $30{ }^{\circ} \mathrm{C}, 40 \mu \mathrm{L}$ del patrón de las $\mathrm{AB}$ o del extracto cárnico debidamente diluido en el disolvente de extracción (ácido perclórico $0.6 \mathrm{M}$ neutralizado con carbonato potásico) se inyectaron directamente sobre la membrana. El cambio de corriente $\left(\Delta_{c}\right)$ producido desde el momento de la inyección hasta los $50 \mathrm{~s}$ se utilizó como señal de medida, siendo ésta proporcional al oxígeno consumido ( $\mathrm{mg}_{2} / \mathrm{L}$ ) durante la reacción enzimática. Debido a que la enzima DAO no es específica para un solo 
sustrato, pues oxida una variedad de monoaminas, diaminas la señal de respuesta del sensor enzimático al inyectar una muestra cárnica se utilizó como indicador del contenido total de $A B$ presentes. Después de cada inyección, la membrana DAO se lavó tres veces con el tampón fosfato (atemperado a $30^{\circ} \mathrm{C}$ ), se secó con un pañuelo de papel y se restauró el equilibrio del sistema con el oxígeno atmosférico durante 3 min antes de una nueva inyección.

En estas condiciones de operación se evaluó y optimizó el sensor enzimático. Se verificó la selectividad de la DAO inmovilizada inyectado una concentración fija de $0.01 \mathrm{mg} / \mathrm{mL}$ de cada una de las aminas comúnmente encontradas en los productos cárnicos curados (HI, PU, CA, TY, SM y SM). Además, se estudio el desarrollo de la reacción enzimática a $30{ }^{\circ} \mathrm{C}$, por triplicado, con patrones de $\mathrm{HI}$ y $\mathrm{PU}(0.02 \mathrm{mg} / \mathrm{mL})$ diluidos en tampón fosfato $100 \mathrm{mM}$, a diferentes condiciones de $\mathrm{pH}(6.2,7.2,8.2$ y 9.2).

\subsubsection{Ensayos de validación del sensor enzimático}

a. Linealidad. La linealidad del sistema enzimático se obtuvo tras el análisis por triplicado de la recta de calibrado de histamina. Así, un intervalo de concentración de 0 a $0.2 \mathrm{mg} / \mathrm{mL}$ del patrón se correlacionó con la señal obtenida y el ajuste de la recta se realizó utilizando el método de mínimos cuadrados.

b. Repetibilidad. La medida de repetibilidad se determinó por inyección repetida de tres muestras: un patrón de histamina $(0.01 \mathrm{mg} / \mathrm{mL})$, un extracto cárnico de un embutido fermentado de 42 días de curado y un jamón curado de 11 meses de maduración. Las mediciones se realizaron en el mismo día, con el mismo equipo y bajo las mismas condiciones de operación. La medida de la repetibilidad se calculó obteniendo el coeficiente de variación (\%). 
d. Estabilidad. La estabilidad de la enzima DAO inmovilizada, se evalúo midiendo: 1) la estabilidad operacional; realizando inyecciones sucesivas sobre la membrana de una disolución patrón de histamina $(0.01 \mathrm{mg} / \mathrm{mL})$ a lo largo del día durante dos días seguidos $y, 2)$ su estabilidad durante el almacenamiento a $4{ }^{\circ} \mathrm{C}$; para ello diez membranas de DAO se almacenaron en tampón fosfato sódico (100 mM, pH 7.2) a $4^{\circ} \mathrm{C}$ y se evaluó una cada semana, obteniendo la respuesta por triplicado de un patrón de histamina $(0.01 \mathrm{mg} / \mathrm{mL})$.

\subsection{Análisis estadístico de resultados.}

El análisis estadístico de los datos se realizó mediante el paquete Statgraphics Plus (v 5.1) bajo el procedimiento ANOVA (análisis de varianza múltiple o simple). En el caso en que el efecto de los factores o de la interacción fuera significativas, las medias fueron comparadas utilizando el método de la diferencia minima significativa de Fisher's (LSD) ( $p<0,05 \circ p<0,001)$. Previamente, se verificó la normalidad de la distribución de los datos y la homogeneidad de las varianzas. Para correlacionar y validar los valores de $\mathrm{Hx}$ y aminas biógenas obtenidos en el sistema enzimático, libre o inmovilizado, respecto a aquellos obtenidos en el HPLC se realizó un análisis de correlación lineal y se obtuvo el coeficiente de correlación. 


\section{Resultados y Discusión}





\section{Resultados y Discusión}

El creciente interés de la industria, especialmente en el sector alimentario por realizar un control de calidad más rápido y económico justifica la demanda de métodos analíticos que cubran sus necesidades y que puedan ser usados en línea. La tecnología de biosensores ha experimentado un notable avance en los últimos años (Luong et al., 1997; Dornelles y Tatsuo, 2002; Dzyadevych et al., 2008), principalmente en el desarrollo de dispositivos aplicados al área de biomedicina; sin embargo, esta tecnología se ha ido transfiriendo paulatinamente de forma horizontal a otros sectores como el medioambiental, y de forma más incipiente al agroalimentario. En este contexto, los biosensores juegan un papel importante para la industria y suponen un avance para el control y estimación de la calidad de los alimentos. Las características más destacables de estos dispositivos son su especificidad, su alta sensibilidad, su corto tiempo de análisis, su capacidad de inclusión en sistemas integrados y su capacidad de trabajar en tiempo real (Yano et al., 1995; Dzyadevych et al., 2008). De este modo, se han desarrollado diferentes tipos de biosensores, siendo los sensores amperométricos enzimáticos los que más se han utilizado en el análisis de alimentos (Terry et al., 2005). La principal dificultad para la aplicación de estos dispositivos es la amplia variedad de posibles productos que se pueden encontrar en la industria, con la consiguiente dificultad en adaptarlos a cada una de las matrices e intervalos de concentración de los analitos en éstos (Prodromidis y Karayannis, 2002). En el presente trabajo de investigación se ha desarrollado un sensor enzimático, utilizando principios simples de construcción, para su aplicación en la detección de marcadores de calidad de la carne y productos cárnicos (embutido fermentado y jamón curado). En particular, se ha puesto a punto para la determinación de hipoxantina $(\mathrm{Hx})$ y aminas biógenas $(\mathrm{AB})$, como indicadores de frescura, maduración y seguridad, así como la validación y correlación de los resultados con los obtenidos por cromatografía líquida de alta resolución (HPLC), 
como método de referencia. A lo largo de este trabajo se irán describiendo cada uno de los puntos planteados. En principio se estableció la puesta a punto y la optimización de las condiciones de operación del sensor enzimático para la medida de cada uno de los compuestos propuestos.

\subsection{Puesta a punto y optimización del sensor enzimático.}

El sensor enzimático es un dispositivo analítico que incorpora un enzima, como elemento de reconocimiento biológico, asociado a un sistema de transducción que permite procesar de manera rápida la señal bioquímica generada en presencia de un sustrato especifico. Los enzimas oxido-reductasas son de particular interés en la construcción de este tipo de biosensores, sobre todo en los de carácter amperométrico. Estos enzimas, durante la reacción con el sustrato, catalizan la transferencia de electrones mediante la reducción de oxígeno (principal co-sustrato de la reacción) u oxidación del agua, a peróxido de hidrógeno $\left(\mathrm{H}_{2} \mathrm{O}_{2}\right)$ para generar una señal eléctrica cuantificable. De manera general, se puede decir que la enzima le confiere la selectividad al sistema mientras que la sensibilidad se la otorga el sistema de transducción y las técnicas electroquímicas empleadas, aunque estas últimas también pueden influir en la selectividad. Tomando en cuenta esas consideraciones y las características del equipo utilizado (ver apartado 4.1.3.), se eligieron por su importancia en la calidad de la carne y sus productos cárnicos, las enzimas xantina oxidasa (XO), en la determinación de hipoxantina, y la diamina oxidasa (DAO) en la detección de aminas biógenas. Aún cuando la utilización de enzimas en este tipo de sensores es de gran ventaja, por su alta selectividad, la actividad de las mismas es regulada por diferentes factores como el $\mathrm{pH}$, la temperatura, la fuerza iónica, su especificidad, la forma de actuación (libre o inmovilizada), entre otros. Es por ello que la puesta a punto de cada uno de los sensores enzimáticos consistió en primer lugar en examinar el comportamiento electroquímico del oxímetro con base en su 
principio de operación (ver apartado 4.3.3.), utilizando un sistema con la enzima libre o un sistema con la enzima inmovilizada, como se describe a continuación.

\subsubsection{Sensor enzimático con la enzima xantina oxidasa.}

La construcción del sensor enzimático con la enzima XO se desarrolló de acuerdo a lo descrito en el apartado 4.3.3. Una vez que el patrón $\mathrm{Hx}$ o el extracto cárnico se inyectó en la celda de reacción ocurre la reacción representada por la ecuación (14). La enzima XO cataliza la oxidación de la $\mathrm{Hx}$ a xantina $(\mathrm{X})$ y luego cataliza la oxidación de ésta en ácido úrico $(\mathrm{AU})$. La corriente resultante de la reducción del oxígeno (mg $\mathrm{O}_{2} / \mathrm{L}$ ) (durante la oxidación de la $\mathrm{Hx}$ ) en el sensor enzimático reduce la presión parcial de oxígeno de manera proporcional, permitiendo el cálculo del contenido de $\mathrm{Hx}$ presente en la muestra (Volpe y Mascini, 1996).

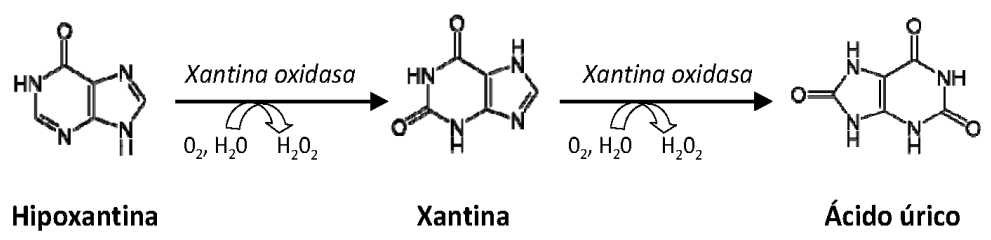

En la figura 15 se representa el oxígeno consumido en función del tiempo de reacción durante la oxidación de un patrón de $\mathrm{Hx}$ en el sistema con la enzima libre. En la curva de evolución se aprecia un primer tramo lineal, útil desde el punto de vista analítico (definido como la velocidad de reacción en función del tiempo), y a medida que avanza la reacción la curva se va haciendo asintótica, ya que se va agotando el contenido de $\mathrm{Hx}$ y, por tanto, disminuyendo la velocidad de la reacción. Escribano et al., (1988) mencionan que debido al hecho que la oxidación de la $\mathrm{Hx}$ y de la $X$ son secuenciales (ecuación 14), el estudio cinético de la reacción de oxidación de la $\mathrm{Hx}$ por sí sola es complicada ya que la actividad secundaria de la XO 
sobre la $\mathrm{X}$ ocurre simultáneamente con la formación de ésta como producto de la primera reacción de oxidación. Así pues, el consumo de oxígeno, como señal de respuesta del sensor enzimático se debe tanto a la oxidación de la $\mathrm{Hx}$ como a la de la X formada de esta reacción, reflejándose pues como la suma de $\mathrm{Hx}+\mathrm{X}$ (Figura 15).

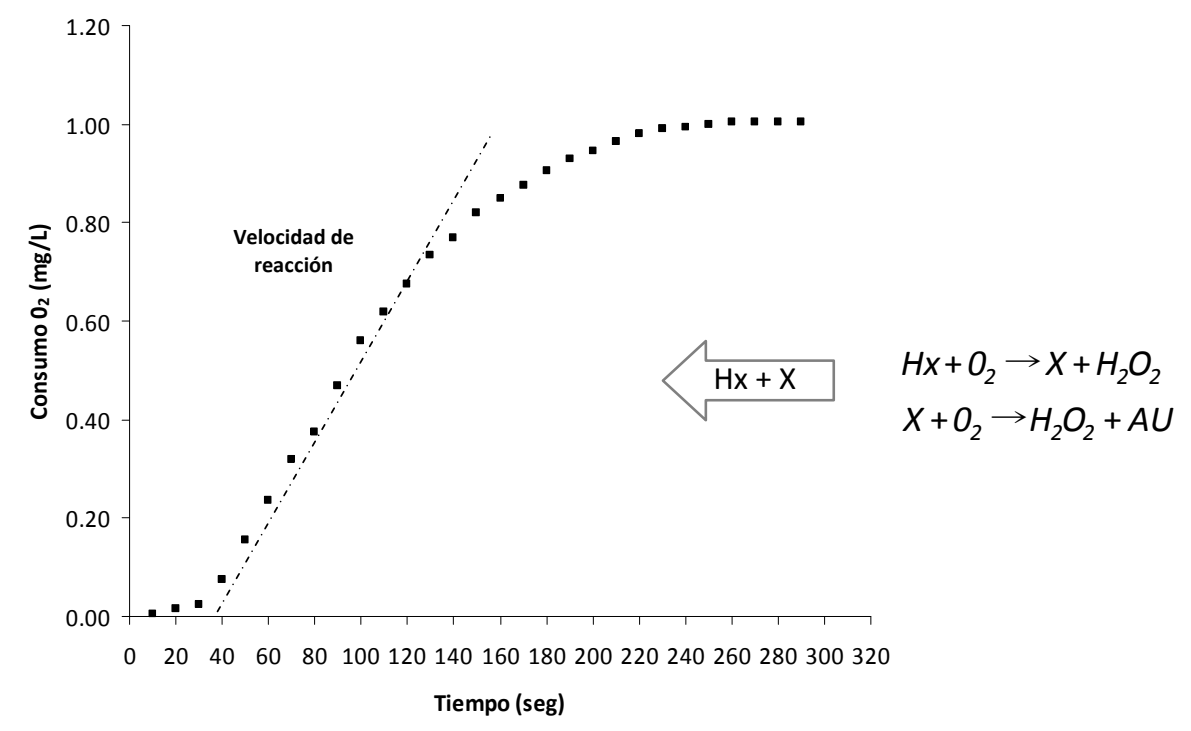

Figura 15. Respuesta del sensor enzimático en el sistema con la enzima libre representada como oxígeno consumido en función del tiempo de reacción. $18.72 \mu \mathrm{M}$ de $\mathrm{Hx}$ en tampón fosfato $50 \mathrm{mM}, \mathrm{pH} 7.6$ a $30^{\circ} \mathrm{C}$ y $0.0169 \mathrm{U}$ de xantina oxidasa.

En este contexto, la optimización del sensor con la enzima XO se desarrolló con la enzima libre y posteriormente se retomaron estos resultados para optimizar el sensor con la enzima inmovilizada. La señal del sensor enzimático $(H x+X)$ se transformó en velocidad de reacción de la enzima XO $\left(\mathrm{mg} / \mathrm{L}\right.$ de $\left.\mathrm{O}_{2} \bullet \mathrm{s}^{-1}\right)$ para la cuantificación de la $\mathrm{Hx}$, como se describirá mas adelante. 


\subsubsection{Sistema enzimático con la enzima libre.}

El potencial eléctrico para la detección amperométrica de hipoxantina se eligió lo suficientemente negativo (- $600 \mathrm{mV}$ ) como para reducir el oxígeno en el electrodo de platino. Este potencial se eligió para evitar reacciones interferentes por parte de otros compuestos, fácilmente oxidables a potenciales positivos (ácido ascórbico, glutatión, ácido úrico, peróxido de hidrógeno) aunque puede dar lugar a una corriente de fondo elevada (Reviejo y Pingarrón, 2000). Sin embargo, operando el sensor con una cantidad mínima de electrolito (membrana de papel húmedo con $\mathrm{KCl}$ 3M) y utilizando una membrana de Teflón permeable al oxígeno se reduce la corriente residual y se incrementa la selectividad del sensor (Falck, 1997).

La cantidad de enzima utilizada en este sistema se optimizó adicionando diferentes concentraciones de enzima hasta obtener una intensidad de corriente suficientemente detectable, manteniendo constante el contenido de $\mathrm{Hx}$, de forma que a mayor cantidad de enzima la velocidad de conversión del sustrato es mayor hasta un punto que es tan rápida que no se detecta. La concentración de enzima $0.0169 \mathrm{U}$ de $\mathrm{XO}$ a $30{ }^{\circ} \mathrm{C}$ fue la que presentó mejores resultados de sensibilidad y permitió obtener un mayor intervalo de linealidad.

El pH de la disolución de reacción, evaluado en un intervalo de pH de 5.6 a 8.6, frente a la velocidad catalítica de la enzima $X O$, se muestra en la figura 16 , observándose que éste afecta la estabilidad de la enzima y por ende la sensibilidad del sensor enzimático. La máxima respuesta se obtuvo a un $\mathrm{pH}$ de 7.6 , valores superiores e inferiores disminuyen la señal de respuesta para una misma concentración de Hx. Resultados similares fueron observados por González et al., (1991); Luong y Male, (1992) que encontraron que el intervalo de pH óptimo para la máxima actividad de la enzima XO se encuentra entre 7.0 - 8.0 con un máximo a 7.5. Nakatani et al., (2005) mencionan que la dependencia del pH se debe al nivel de 
protonación, alterando la velocidad de formación o rotura del complejo enzimasustrato. Como resultado de este estudio, la disolución de reacción a pH 7.6 se utilizó para las subsecuentes experiencias.

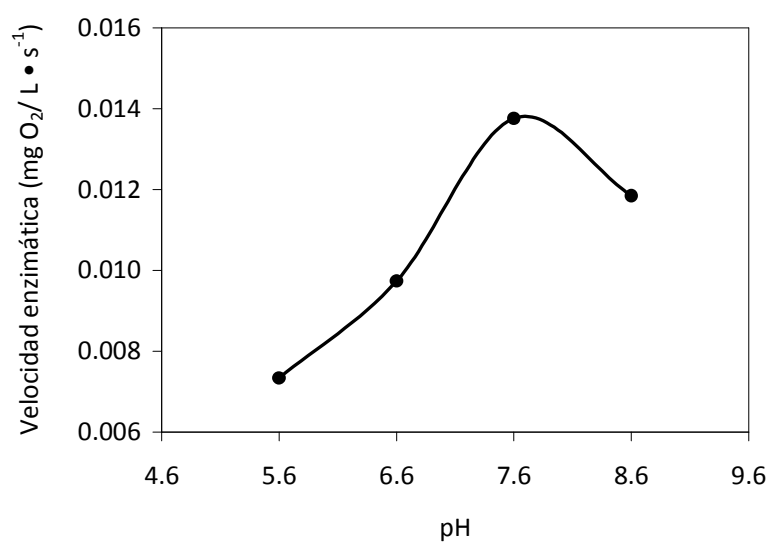

Figura 16. Efecto del pH sobre la velocidad de reacción de la enzima xantina oxidasa determinado en el sensor enzimático con la enzima libre. $20 \mu \mathrm{L}$ de patrón de $\mathrm{Hx}$ (1 $\mathrm{mM}$ ), en tampón fosfato sódico a diferente $\mathrm{pH}, 0.0169 \mathrm{U}$ de $\mathrm{XO}$ a $30^{\circ} \mathrm{C}$.

El efecto de la temperatura del medio de reacción sobre la velocidad catalítica de la enzima XO se investigó por dos vías: Evaluando la desaparición de Hx durante su oxidación (apartado 4.3.3.1.1.) por HPLC (Figura 17) y midiendo el consumo de oxígeno en el sensor enzimático a diferentes temperaturas $\left(25,30,35\right.$ y $40{ }^{\circ} \mathrm{C}$ ) (Figura 18). La tendencia general indica que a temperaturas altas la velocidad de reacción de una enzima es mayor. En el primer caso se comprueba esa teoría, en general se observaron diferencia significativas $(p<0.05)$ en la oxidación de $\mathrm{Hx}$ a diferentes temperaturas, sobretodo al final del proceso, y así por ejemplo, a temperaturas de $40{ }^{\circ} \mathrm{C}$ la oxidación total de la $\mathrm{Hx}$ ocurre a los $40 \mathrm{~s}$ respecto a $80 \mathrm{~s}$ a $25{ }^{\circ} \mathrm{C}$. La oxidación de $\mathrm{Hx}$ a $30^{\circ} \mathrm{C}$ fue la que mostró la mejor estabilidad en cuanto a dispersión de resultados. 


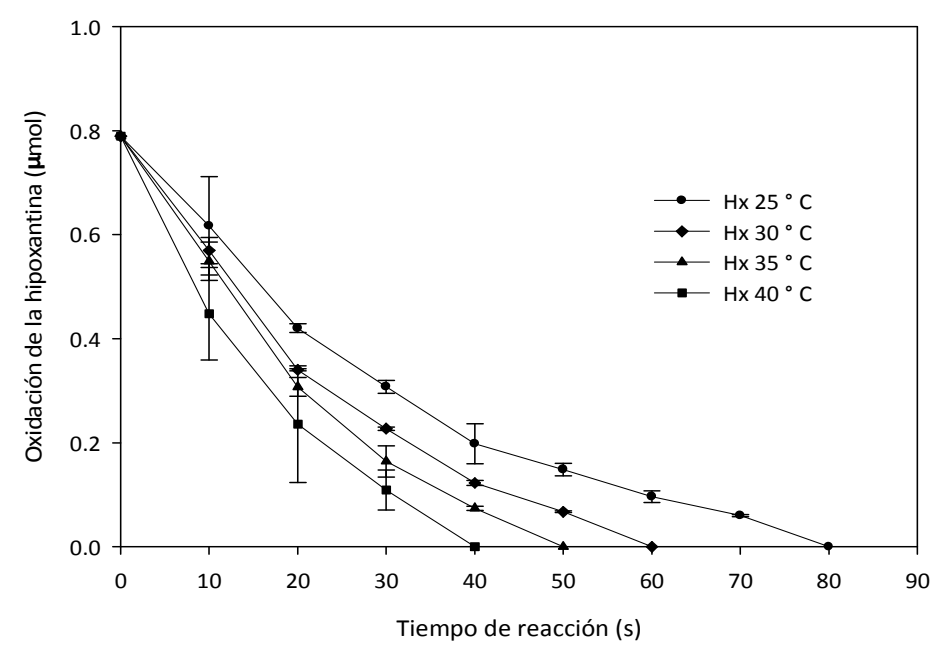

Figura 17. Efecto de la temperatura sobre la velocidad de reacción de la enzima xantina oxidasa determinada por HPLC con la enzima libre.

Cuando se realizó el estudio empleando el sensor enzimático se observó que la velocidad de reacción aumentó con la temperatura del medio de reacción hasta alcanzar un máximo a $35{ }^{\circ} \mathrm{C}$ (Figura 18) y por encima de esta temperatura la sensibilidad de sensor disminuyó ligeramente. Esta disminución puede atribuirse a la reducción en los niveles de oxígeno en la disolución de reacción. Por otro lado, se ha descrito que a temperaturas más altas la desactivación térmica de la enzima puede ocurrir, reduciendo su estabilidad (Karube et al., 1984; Rahman et al., 2007). Por consiguiente y en base en estos resultados, se eligió la temperatura de $30^{\circ} \mathrm{C}$ para los sucesivos análisis. 


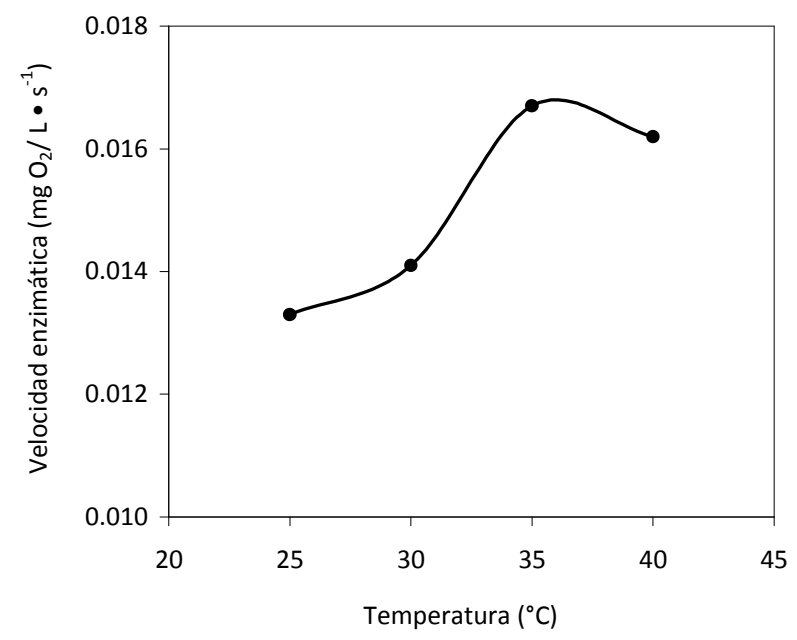

Figura 18. Efecto de la temperatura sobre la velocidad de reacción de la xantina oxidasa determinado en el sensor enzimático con la enzima libre. $20 \mu \mathrm{L}$ de patron de $\mathrm{Hx}$ $(1 \mathrm{mM})$, en tampón fosfato $\mathrm{pH} 7.6,0.0169 \mathrm{U}$ de XO a diferentes temperaturas.

\section{Ensayos de validación}

Empleando las condiciones experimentales anteriores, se evalúo la linealidad del sensor enzimático y para ello se construyó una recta de calibrado con patrones de $\mathrm{Hx}$, en un intervalo de concentraciones seleccionadas. Sin embargo, cuando se inyectaron las muestras de carne, el tramo lineal a partir del cual se obtiene la velocidad de reacción no fue muy estable en alguno de sus puntos, haciendo difícil su obtención. La acumulación del oxígeno consumido durante $190 \mathrm{~s}$, tiempo al cual se asegura por exceso la oxidación total de la $\mathrm{Hx}$ y la $\mathrm{X}$ formada en las muestras de carne, mostró una excelente correlación para cuantificar la señal de dichas muestras. Bajo estas condiciones se obtuvo la curva típica de saturación de la enzima en función de la concentración de $\mathrm{Hx}$ y con el método de mínimos cuadrados se calculó la linealidad, por triplicado (Figura 19), obteniendo un intervalo lineal de 8.68 a $26.05 \mu \mathrm{M}$ de $\mathrm{Hx}$. 


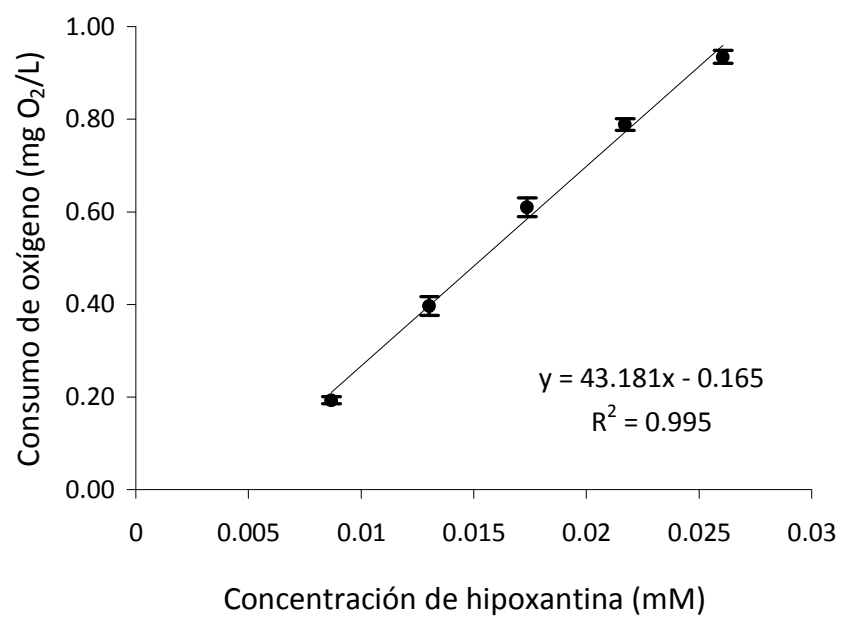

Figura 19. Curva de calibrado de hipoxantina en el sensor enzimático con la enzima libre. (Consumo de oxígeno $\left(\mathrm{mg} \mathrm{O}_{2} / \mathrm{L}\right.$ ) a $190 \mathrm{~s}$ frente a la concentración de $\mathrm{Hx}(\mathrm{mM})$ ). Las barras de error indican la desviación estándar de la medida de tres mediciones.

La sensibilidad de detección en el sensor enzimático como se ha visto, puede verse afectada por la propia concentración de $\mathrm{Hx}$, inhibiendo a la enzima por exceso de sustrato o producto formado $\left(\mathrm{H}_{2} \mathrm{O}_{2}\right.$ y $\left.\mathrm{AU}\right)$ o por la competencia que existe entre la Hx y la X por los sitios activos de la enzima (Jezewska, 1973) o bien por la limitación de oxígeno en el medio (Hu y Liu, 1997). Lecturas superiores a $1 \mathrm{mg} / \mathrm{L}$ de oxígeno consumido o velocidades de reacción mayores de $0.064 \mathrm{mg} / \mathrm{L} \cdot \mathrm{s}^{-1}$ sugieren un exceso de $\mathrm{Hx}$ y la muestra de carne deberá ser diluida para adecuarse al intervalo lineal de detección y obtener una buena cuantificación.

La repetibilidad se calculó inyectando sucesivamente un patrón de $\mathrm{Hx}$ y/o un extracto de carne de 7 horas post-mortem $(n=7)$, los resultados obtenidos se muestran en la tabla 15. Una pérdida gradual de sensibilidad se observó cuando se inyectaron las muestras de carne, posiblemente debido a problemas de interferencia por proteínas u otros compuestos presentes en el extracto cárnico (Qiong et al., 
1998). A fin de minimizar este efecto, el sistema se lavó después de tres inyecciones con una disolución de cloruro de sodio ( $\mathrm{NaCl}) 125$ mM (Luong y Male, 1992), ya que la solubilidad de la mayoría de las proteínas disminuye a concentraciones altas de sal.

Por otro lado, por cada molécula de Hx que se oxida en presencia de la enzima XO se producen dos moléculas de peróxido de hidrógeno $\left(\mathrm{H}_{2} \mathrm{O}_{2}\right)$ y una de ácido úrico (AU) (Volpe y Mascini, 1996). Aunque estos compuestos no se encuentran usualmente en la carne fresca y no interfieren con la señal del sensor enzimático a los potenciales eléctricos usados, podrían inhibir a la enzima XO por exceso de producto. Para observar este efecto, una disolución patrón de $\mathrm{Hx}$ se enriqueció con diferentes concentraciones de $\mathrm{H}_{2} \mathrm{O}_{2}$ O AU y se inyectó en el sistema. La adición de $\mathrm{H}_{2} \mathrm{O}_{2}$ tuvo mayor efecto en reducir la señal detectada que la de $\mathrm{AU}$ cuando se comparaba con la del patrón de Hx no enriquecido. Se observó una disminución del $5.80 \%$ de la señal amperométrica a concentraciones altas de $\mathrm{H}_{2} \mathrm{O}_{2}\left(1 \mathrm{Hx}: 10 \mathrm{H}_{2} \mathrm{O}_{2}\right.$, considerando en ésta la concentración de $\mathrm{H}_{2} \mathrm{O}_{2}$ adicionada y la formada durante la oxidación de la $\mathrm{Hx}$ ). Mientras que a esos mismos niveles de concentración de $\mathrm{AU}$, la señal disminuyó 3.0 \% respecto la señal del patrón sin enriquecimiento.

La estabilidad de la disolución enzimática de XO durante el almacenamiento (ver apartado 4.3.1.) fue muy buena ya que no se detectaron diferencias significativas $(p<0.05)$ entre las disoluciones almacenadas a $4{ }^{\circ} \mathrm{C}$ y usadas durante cinco semanas consecutivas a una misma concentración de $\mathrm{Hx}$ (Figura 20). Estos resultados, sugieren la buena estabilidad de la enzima en dichas condiciones de almacenamiento y otorgan fiabilidad a la determinación de $\mathrm{Hx}$ en este sensor enzimático. 


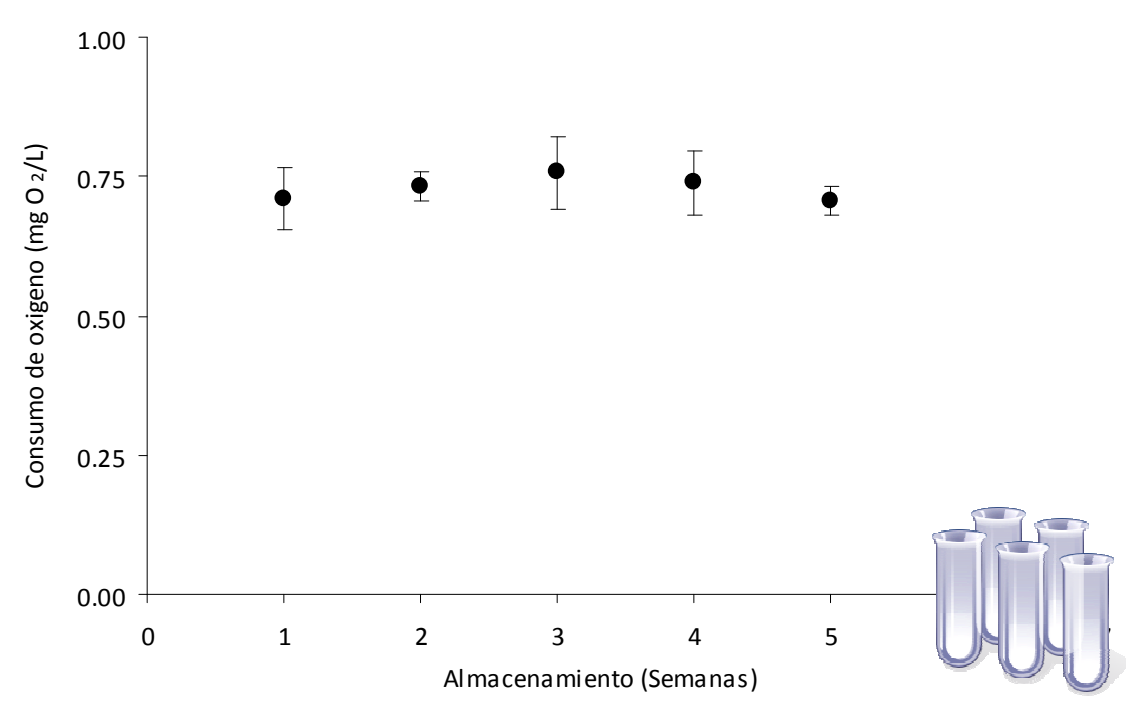

Figura 20. Estabilidad de la xantina oxidasa en disolución en almacenamiento a $4{ }^{\circ} \mathrm{C}$. Las barras de error indican la desviación estándar de la medida de cuatro mediciones/día durante tres días consecutivos.

\subsubsection{Sistema enzimático con la enzima inmovilizada.}

Un paso importante en la construcción del sensor enzimático con la enzima inmovilizada, es precisamente el proceso de inmovilización, a fin de retener la máxima actividad de la enzima para que pueda ser utilizada de forma repetida y asegurar el máximo contacto de enzima con el sustrato. Tomando en cuenta las condiciones de optimización del sistema con la enzima libre, se procedió a la inmovilización de la enzima y aún cuando existen distintas técnicas de inmovilización, la enzima XO se inmovilizó según el protocolo descrito en el apartado 4.3.3.2.1. por entrecruzamiento con glutaraldehído, sobre una membrana preactivada Immunodyne ABC (Nylon 66, con un tamaño de poro de $0.45 \mu \mathrm{m}$ ), la cual ayudó a mejorar la retención y estabilidad de la enzima mediante la unión covalente en su superficie. 
La cantidad de enzima inmovilizada se optimizó y se evaluó hasta obtener una intensidad de consumo de oxígeno y/o velocidad de reacción lo suficientemente sensible en el oxímetro manteniendo constante la concentración de $\mathrm{Hx}$ y la cantidad de glutaraldehído (2 \%). Así, se añadió a la disolución de inmovilización 7, 15 o $20 \mu \mathrm{L}$ de enzima, con una actividad de $1.3 \mathrm{U} / \mathrm{mg}$ de proteína, siendo la cantidad de $15 \mu \mathrm{L}$ ( $0.50 \mathrm{U}$ ) de $\mathrm{XO}$ a $30{ }^{\circ} \mathrm{C}$ la que presentó mejores resultados de sensibilidad y mayor intervalo de linealidad. A mayores concentraciones de enzima se observó mayor señal de respuesta hasta un punto que no se detectó la velocidad de reacción por ser muy rápida. Mientras que a bajas concentraciones de enzima, aún cuando la respuesta fue buena el número de inyecciones que se podían realizar disminuyó considerablemente.

La cantidad de glutaraldehído ( 2 \%) utilizada en la disolución de inmovilización de la enzima XO se seleccionó tras minuciosos ensayos y comparaciones con trabajos previos (Mulchandani et al., 1990; Hu y Liu, 1997; Nakatani et al., 2005). En efecto, se observó que la capa de enzima sobre la membrana cuando se utilizaba menor cantidad de glutaraldehído (1 \%) se perdía fácilmente debido a un escaso entrecruzamiento entre la enzima y el glutaraldehído, en tanto que a mayores cantidades de glutaraldehído (3\%) la polimerización de la enzima ocurría muy rápido y se formaba una película irregular de enzima con características de un gel, que obstaculizaba la difusión del oxígeno hacia el electrodo de platino disminuyendo la sensibilidad de detección. Además, para evitar la rápida polimerización de la enzima aún con el $2 \%$ de glutaraldehído, fue necesario adicionar éste en disolución (8 $\mu \mathrm{L}$ de una disolución al $12.5 \%$ ) de manera muy rápida con el resto de la disolución de inmovilización.

El acetato de celulosa se utiliza principalmente para proteger al electrodo de platino, a potenciales positivos, de interferencias electroquímicas (Volpe y Mascini, 
1996; Nakatani et al., 2005). Aún así, en las condiciones de inmovilización ensayadas en este trabajo (potenciales negativos), el acetato de celulosa limitó la contaminación de la membrana de xantina oxidasa de algunos otros componentes del extracto de carne, protegiendo de la pérdida de sensibilidad (Qiong et al., 1998). Incluso, se formó una película barrera de protección para la enzima durante el lavado y secado con el pañuelo de papel que se realiza antes de cada inyección, si la comparamos con una membrana que no tenía dicha película, en la que se observó una pérdida de actividad considerable, medida por la reducción del número de determinaciones viables, posiblemente debida a la pérdida de la enzima y no a la pérdida de su actividad.

A fin de comprobar la unión covalente de la enzima a la membrana, una vez fue elegido el método de inmovilización, se realizó una exploración rápida ("screening") del contenido de proteína de la disolución de lavado de la membrana durante el proceso de inmovilización con y sin la adición de cisteína, según el método propuesto por Smith et al., (1985). En el cual se utilizó el ácido binciconínico-BCA, como agente reactivo y la albúmina de suero bovino-BSA, como proteína patrón a una lectura de absorbancia de $565 \mathrm{~nm}$. Los resultados mostraron la ausencia de proteína en la disolución de lavado sin cisteína, lo que supone que toda la enzima añadida se quedo unida a la membrana.

\section{Ensayos de validación}

La reproducibilidad en la inmovilización de la enzima XO se evalúo construyendo la recta de calibrado utilizando membranas inmovilizadas en diferentes días, las cuales fueron evaluadas en distintos tiempos y con dos oxímetros diferentes. En la figura 21 se muestra la recta de calibrado promedio de seis membranas evaluadas por duplicado. Los resultados indican que el procedimiento de inmovilización de las membranas es perfectamente reproducible. Sin embargo, para asegurar la fiabilidad 
de los resultados cuando se utiliza una membrana nueva para el análisis de $\mathrm{Hx}$ en muestras cárnicas es conveniente hacer una recta de calibrado a las condiciones ambientales existentes o estar monitorizando un punto especifico de referencia durante los análisis.

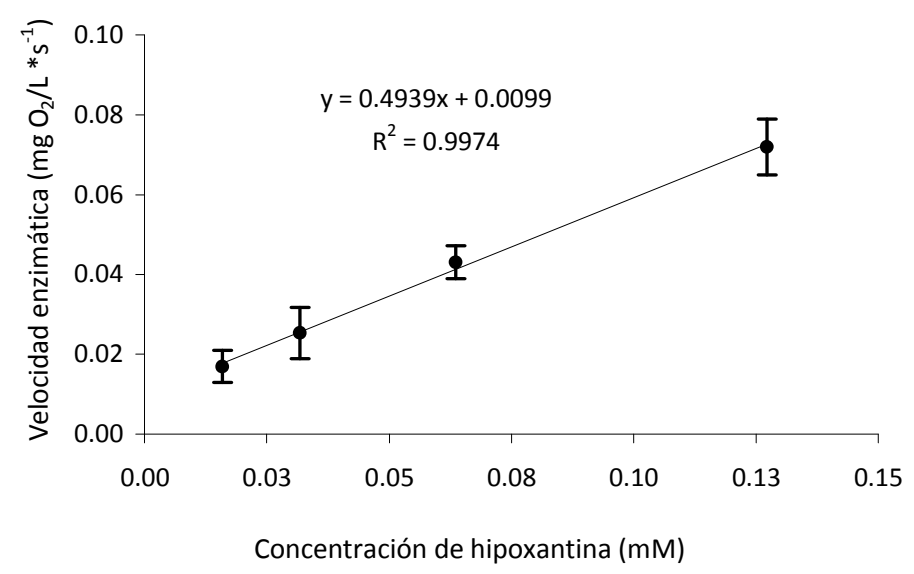

Figura 21. Curva de calibración de hipoxantina en el sensor enzimático con la enzima xantina oxidasa inmovilizada. (Consumo de oxígeno $\left(\mathrm{mg} \mathrm{O}_{2} / \mathrm{L} \cdot \mathrm{s}^{-1}\right.$ ) a $10 \mathrm{~s}$ frente a la concentración de $\mathrm{Hx}(\mathrm{mM})$ ). Las barras de error indican la desviación estándar de la medida de seis membranas.

La relación lineal entre la concentración de $\mathrm{Hx}$ en el intervalo seleccionado (0 - 1 $\mathrm{mM}$ ) y la respuesta del sensor enzimático, como velocidad de reacción de la enzima $\mathrm{XO}$ a los $10 \mathrm{~s}$ se muestra en la Figura 21. El intervalo lineal (15.63 - $127.00 \mu \mathrm{M})$ en este sistema fue más amplio que en el sistema con la enzima libre (Tabla 15); aunque el límite inferior de detección fue más bajo en este último (apartado 5.1.1.1. y Figura 7). En el sistema inmovilizado, el patrón de hipoxantina o la muestra cárnica se inyectó directamente sobre la membrana $\mathrm{XO}$, y el disolvente de extracción de la muestra (ácido perclórico neutralizado) generó una señal eléctrica incluso en la ausencia de la enzima, lo cual explica la respuesta residual en este sistema que interfiere con los bajos niveles de $\mathrm{Hx}$. Sin embargo, el intervalo de detección se encuentra dentro de los intervalos detectados con otros sistemas enzimáticos 
(Watanabe et al., 1983; Carsol y Mascini, 1998; Hu et al., 2000; Shizuko et al., 2005). Con la enzima libre la señal del disolvente de extracción posiblemente se reduce al mínimo al diluirse en la disolución de la reacción (tampón fosfato 50 mM, pH 7.6), y la sensibilidad es por lo tanto mayor.

La repetibilidad obtenida con los patrones de $\mathrm{Hx}$ y las muestras de carne fue muy buena en ambos casos (Tabla 15). Los resultados al analizar el extracto de carne mostraron mayor variabilidad al igual que con la enzima libre posiblemente debido a la contaminación de la membrana por los propios componentes de la muestra. De este modo, la precisión de la medida en este sistema dependió más de la suciedad de la membrana en el momento de la medida que de la concentración de oxígeno atmosférico presente, cuya concentración puede reducir o aumentar la exactitud del sensor (Prodromidis y Karayannis, 2002).

Tabla 15. Resultados de validación del sensor enzimático en ambos sistemas, libre e inmovilizada.

\begin{tabular}{lcc}
\hline \multicolumn{1}{c}{ Parámetro ${ }^{*}$} & \multicolumn{2}{c}{ Sensor enzimático } \\
\cline { 2 - 3 } & Sistema con enzima libre & Sistema con enzima inmovilizada \\
\hline Rango lineal $(\mu \mathrm{M})$ & $8.68-26.05\left(\mathrm{R}^{2}=0.992\right)$ & $15.63-127.00\left(\mathrm{R}^{2}=0.995\right)$ \\
Repetibilidad $(\mathrm{n}=7, \mathrm{CV}(\%))$ & 2.29 & 2.24 \\
Patrón & 4.81 & 5.04 \\
Muestra de carne & hasta 30 inyecciones sucesivas a $30^{\circ} \mathrm{C}$ \\
Estabilidad & y hasta 2 meses a $4{ }^{\circ} \mathrm{C}$ \\
Correlación con HPLC $(r)$ & 0.9621 \\
\hline * Todos los parámetro se determinaron usando la solución enzimática de xantina oxidasa recién preparada y la \\
membrana enzimática en condiciones iniciales.
\end{tabular}

La eficacia del análisis se determinó calculando la recuperación después de adicionar tres niveles diferentes de concentración de $\mathrm{Hx}(0.5,1.0$ y 1.5$)$ a un extracto de carne de 7 horas post-mortem. Los datos de recuperación se presentan en la tabla 16 y se encontraron en un intervalo de 99.5 a $105.2 \%$. 
Tabla 16. Recuperación de la hipoxantina en muestras de lomo de cerdo (Longissimus dorsi) de 7 horas post-mortem en el sensor enzimático con la enzima inmovilizada.

\begin{tabular}{|c|c|c|c|c|c|}
\hline \multirow{2}{*}{$\begin{array}{c}\text { Nivel } \\
\text { agregado }\end{array}$} & \multicolumn{4}{|c|}{ Hipoxantina $(\mu \mathrm{mol} / \mathrm{L})^{\mathrm{a}}$} & \multirow{2}{*}{$\begin{array}{c}\text { Recuperación } \\
\text { (\%) }\end{array}$} \\
\hline & Muestra & $\begin{array}{c}\text { Valor } \\
\text { añadido } \\
\end{array}$ & Valor teórico ${ }^{\mathrm{b}}$ & $\begin{array}{c}\text { Valor } \\
\text { recuperado }\end{array}$ & \\
\hline 0.50 & 46.98 & 23.41 & 70.39 & 74.04 & $105.2 \%$ \\
\hline 1.00 & 46.98 & 46.81 & 93.79 & 97.86 & $104.3 \%$ \\
\hline 1.50 & 46.98 & 71.23 & 118.22 & 117.65 & $99.5 \%$ \\
\hline
\end{tabular}

${ }^{a}$ Cada valor se corresponde con cuatro repeticiones en cada nivel de concentración

${ }^{\mathrm{C}}$ El valor teórico contempla el valor añadido mas el intrínseco de la muestra

Por otro lado, la membrana de XO se mantuvo estable durante las primeras 30 inyecciones, como se comprobó por inyecciones repetidas de patrones de $\mathrm{Hx}$ (apartado 4.3.3.3.). Posteriormente, la sensibilidad disminuyó entre las 50 y 70 inyecciones con pérdidas de actividad del $27.97 \%$ y del $55.44 \%$, respectivamente (Figura 22). Incluso en estas condiciones, la membrana de XO aún podía ser utilizada realizando una nueva calibración, con buenos resultados. Cabe mencionar que la estabilidad de la membrana usando tampón fosfato (50 mM, pH 7.6), como disolvente de inyección de los patrones de $\mathrm{Hx}$, se incrementó considerablemente (60 inyecciones durante tres días, almacenando la membrana a $4{ }^{\circ} \mathrm{C}$ cuando ésta no era utilizada).

La estabilidad de la membrana de XO durante el almacenamiento a $4{ }^{\circ} \mathrm{C}$ se evaluó cada quince días, obteniendo para cada membrana su curva de calibración respectiva por duplicado (Figura 23). La señal en el sensor enzimático fue estable durante dos meses, con un coeficiente de variación entre las membranas del 13.39\%, entonces comenzó a disminuir la actividad de la membrana en aproximadamente $38.17 \%$ después de tres meses, manteniendo aún muy buena linealidad. Sin embargo, la condición de operación de esa membrana se redujo casi en un $50 \%$. 


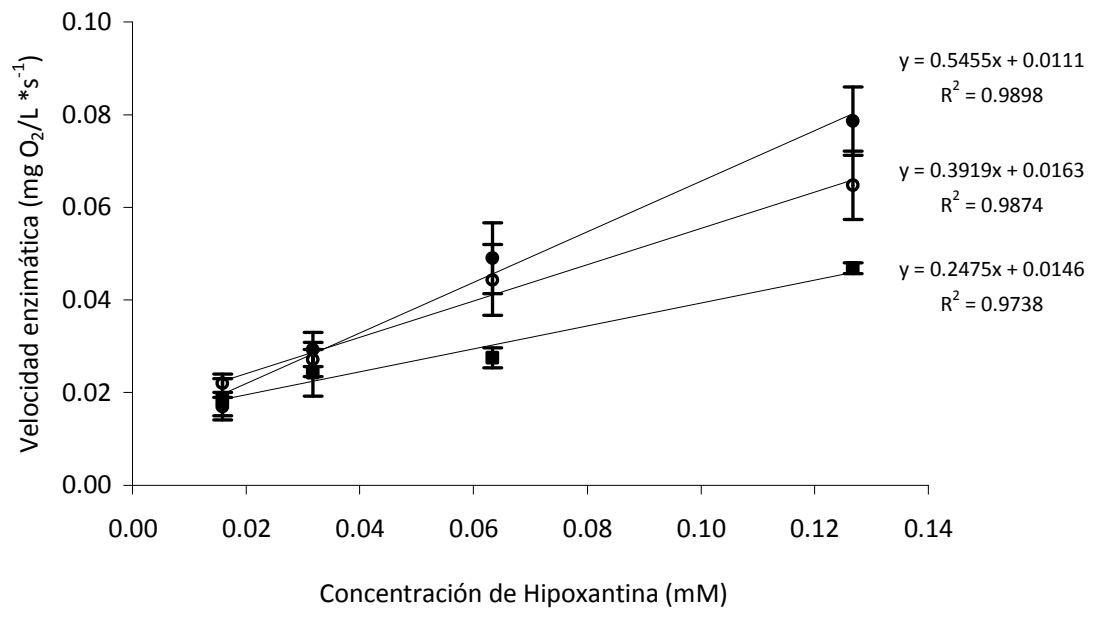

Figura 22. Estabilidad de operación de la membrana de xantina oxidasa (•) 0-30 inyecciones (০) 31-50 y ( $\mathbf{\square}$ ) 51-70 inyecciones. Las barras de error indican la desviación estándar de la media de tres determinaciones.

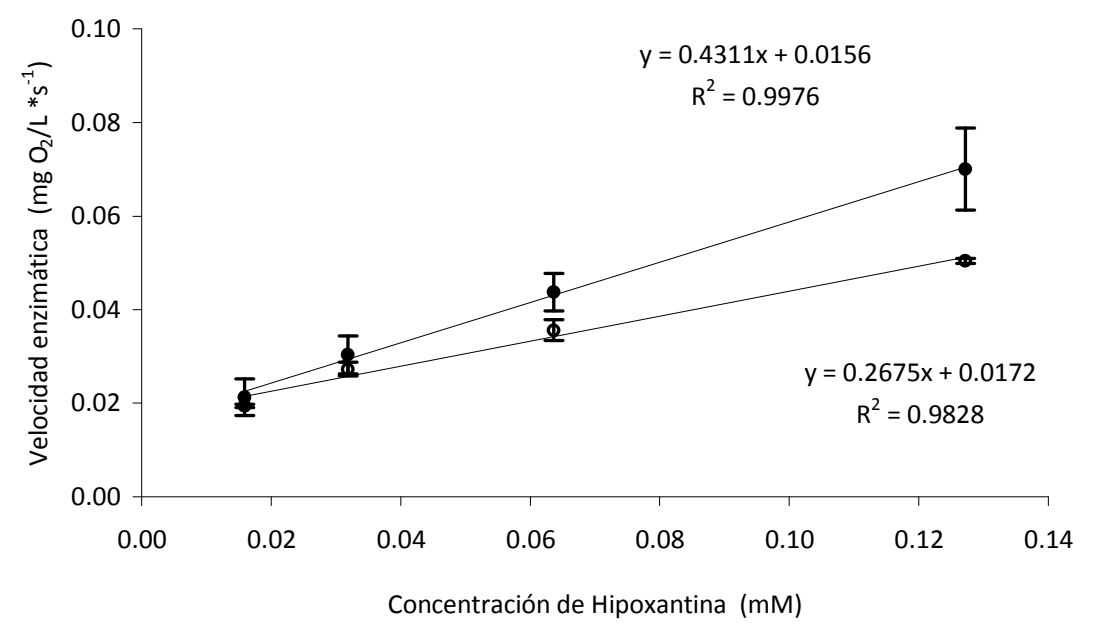

Figura 23. Estabilidad de la membrana de xantina oxidasa almacenada a $4{ }^{\circ} \mathrm{C}$. (•) Curva de calibración de hipoxantina durante dos meses ( $n=5$ membranas) (0) Curva de calibración de hipoxantina después de tres meses. Las barras de error indican la desviación estándar. 


\subsubsection{Estudio de la oxidación de la hipoxantina}

Con base en los estudios anteriores y conociendo que la respuesta del sensor enzimático se debe a la acción catalítica de la enzima XO sobre la Hx y la X, se evaluó por HPLC el desarrollo de la reacción enzimática con la enzima libre (apartado 4.3.3.1.1.). Así, la desaparición de la $\mathrm{Hx}$, la formación y acumulación de la $\mathrm{X}$ y la acumulación de $\mathrm{AU}$ como productos de la reacción oxidativa de $\mathrm{Hx}$ fueron analizados. Los resultados obtenidos a $30{ }^{\circ} \mathrm{C}$ se muestran en la figura 24 . La máxima formación de $\mathrm{X}$ se alcanzó justo a la mitad del período total de oxidación de la $\mathrm{Hx}$ (a los $30 \mathrm{~s}$ de un período total de $60 \mathrm{~s}$ requeridos para oxidar totalmente la $\mathrm{Hx}$ a $30{ }^{\circ} \mathrm{C}$ ) cuando hay aún $33.11 \%$ de $\mathrm{Hx}$ con respecto a su concentración inicial. Este porcentaje fue similar en todas las temperaturas ensayadas $\left(25,30,35\right.$ y $\left.40^{\circ} \mathrm{C}\right)$ con un coeficiente de variación entre ellas del $8.48 \%$. Así pues, la acumulación de la X durante la reacción enzimática es un indicador fiable de la mayor afinidad catalítica de la enzima XO sobre la Hx, como ya ha observado Jezewska, (1973). De este modo, la afinidad de la XO por la xantina es la mitad que la afinidad por la $\mathrm{Hx}$, y puede representarse como $\left(\mathrm{Hx}+\frac{1}{2} \mathrm{X}\right)$, como planteó Yano et al., (1995).

Por lo tanto, derivado de este análisis, en el cual se conoce la proporción máxima de xantina formada, se pueden ajustar los resultados de la señal del sensor $(H x+X)$ detectados en las muestras de carne obtenidos en cada uno de los sistemas enzimáticos, a fin de comparar más exactamente la señal obtenida en el sensor con los valores de $\mathrm{Hx}$ obtenidos por HPLC (ver apartado 5.2). En cada uno de los productos analizados con el sensor enzimático (ver apartado 5.3) se describirá la forma en que se realizó dicho ajuste. 


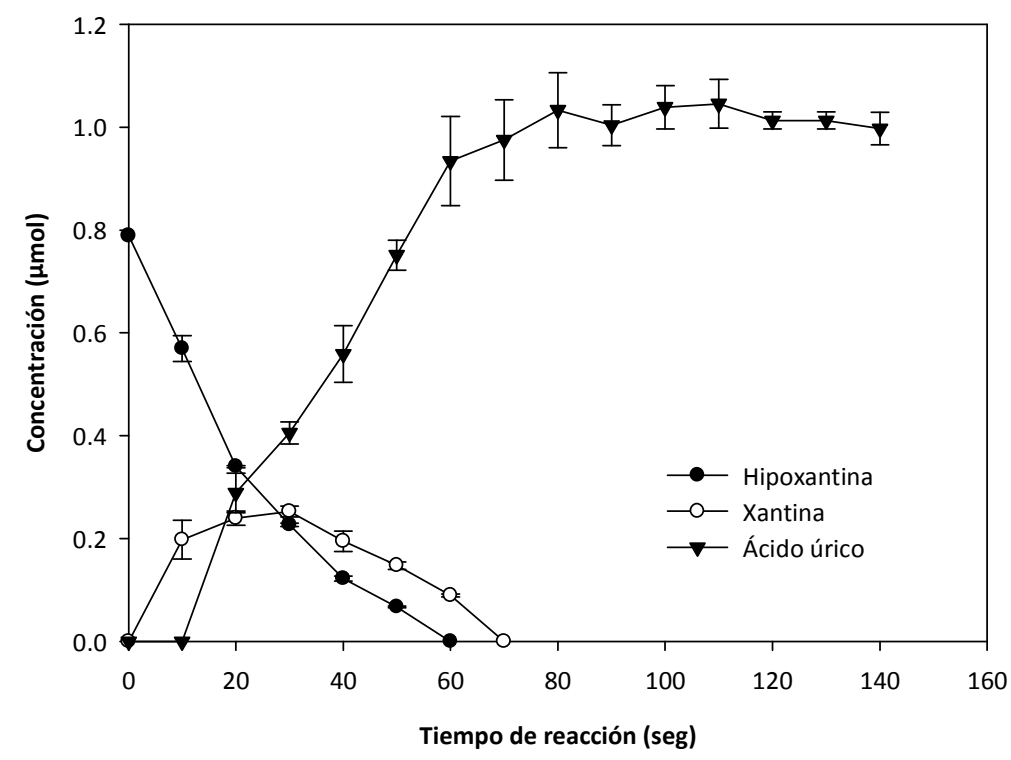

Figura 24. Evolución de la reacción de oxidación de hipoxantina en presencia de la enzima xantina oxidasa a $30{ }^{\circ} \mathrm{C}$ y medida por HPLC. Las barras de error indican la desviación estándar de la media de cuatro muestras.

\subsubsection{Sensor enzimático con la enzima diamina oxidasa.}

La construcción del sensor enzimático para aminas biógenas se desarrolló con base en lo descrito en el apartado 4.3.6.1., utilizando como elemento de reconocimiento biológico la enzima comercial diamina oxidasa (DAO, EC. 1.4.3.6.) inmovilizada en una membrana. Se decidió utilizar la enzima inmovilizada debido a que en estas condiciones la enzima es más estable y puede ser reutilizada múltiples veces. En presencia de oxígeno, la DAO cataliza la deaminación oxidativa de las mono y di aminas para producir aldehídos, amoníaco y peróxido de hidrógeno (Mondovi et al., 1971), como se muestra en la siguiente ecuación (15),

$$
\mathrm{RCH}_{2} \mathrm{NH}_{2}+\mathrm{O}_{2}+\mathrm{H}_{2} \mathrm{O} \stackrel{\text { Diamina oxidasa }}{\longrightarrow} \mathrm{RCHO}+\mathrm{H}_{2} \mathrm{O}_{2}+\mathrm{NH}_{3}
$$


La señal de respuesta del sensor durante la reacción enzimática exhibe una evolución cinética característica de las enzimas oxido-reductasas. La curva del progreso de la reacción (Figura 25) pone de manifiesto que la reacción puede seguirse por varias vías: determinando la velocidad de reacción $\left(\mathrm{mg} / \mathrm{L} \mathrm{de} \mathrm{O}_{2} \bullet \mathrm{s}^{-1}\right)$ a los $30 \mathrm{~s}$, midiendo el consumo acumulado de oxígeno $\left(\mathrm{mg} / \mathrm{L}\right.$ de $\left.\mathrm{O}_{2}\right)$ a los $50 \mathrm{~s}$ o detectando el cambio de corriente $\left(\Delta_{c}\right)$ derivado de ese consumo. Cabe destacar que estas medidas son proporcionales a la concentración de amina de la muestra siempre y cuando esta contenga un único patrón de una amina específica. En cambio cuando se analizó una muestra cárnica, que contiene una diversa combinación y concentración de $A B$, la señal de respuesta y la velocidad de reacción se deben a la combinación de todas ellas. Esto se complica debido a que la selectividad de la enzima DAO es diferente para las distintas aminas (condición que se abordará más adelante). Para obtener la medida amperométrica de dichas muestras, el cambio de corriente a los 50 s fue la mejor opción y se utilizó como un indicador del contenido total de AB.

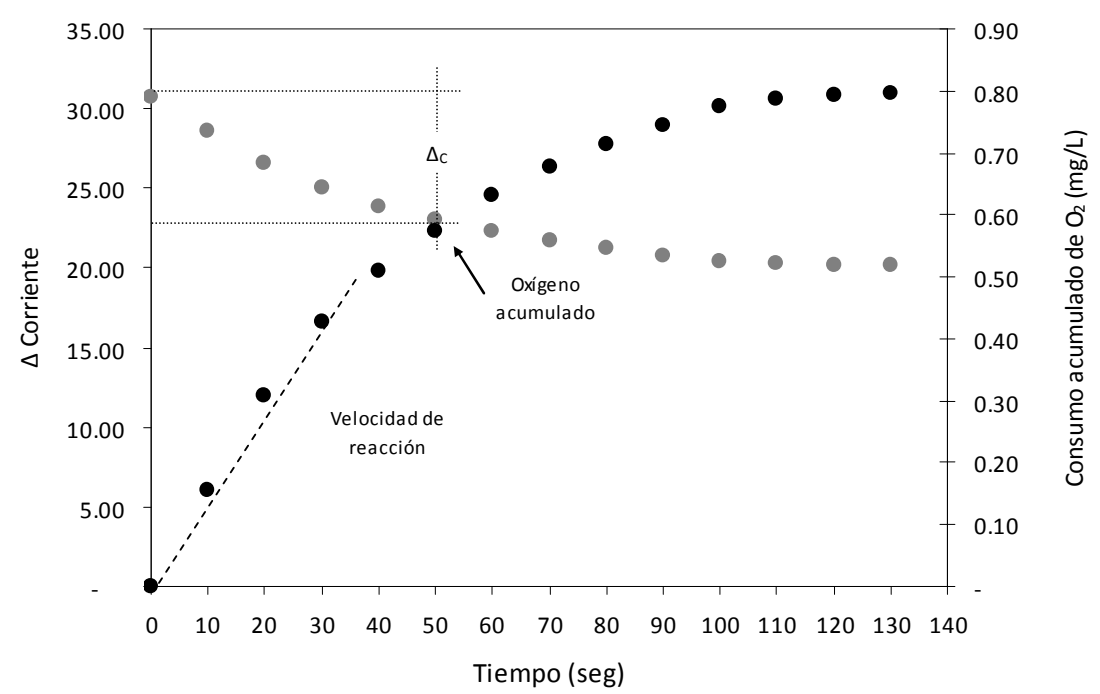

Figura 25. Respuesta del sensor enzimático representado por el consumo de oxígeno acumulado $(\bullet)$ y el cambio de corriente $(\bullet)$ en función del tiempo de reacción en un patrón de histamina $(0.02 \mathrm{mg} / \mathrm{mL})$ en tampón fosfato $100 \mathrm{mM}, \mathrm{pH} 7.4$ a $30^{\circ} \mathrm{C}$. 


\subsubsection{Inmovilización de la enzima diamina oxidasa.}

El método de inmovilización es uno de los parámetros más importante en el desarrollo del sensor enzimático. La DAO comercial exhibe baja actividad enzimática (0.18 U/mg de sólido). El método de inmovilización por entrecruzamiento con glutaraldehído permite obtener alta carga de enzima sobre la membrana y por tanto mejorar la operación del sensor (Carelli et al., 2007); sin embargo, Karube et al., (1980) mencionan que la DAO puede ser desnaturalizada con facilidad en presencia de glutaraldehído. En este contexto, varias metodologías de inmovilización se ensayaron antes de elegir como óptimo el método descrito en el apartado 4.3.6.1. Las condiciones iniciales de inmovilización de la DAO se definieron tomando en cuenta lo descrito por varios autores (Male et al., 1996; Bouvrette et al., 1997; Carelli et al., 2007) y las sugerencias especificadas por la casa comercial en el manejo de la enzima (tampón fosfato 100 mM, pH 7.2). Para este fin, se ensayaron las siguientes experiencias, utilizando la $\mathrm{HI}(0.01 \mathrm{mg} / \mathrm{mL})$ como patrón de referencia.

\begin{tabular}{|c|c|}
\hline Experiencia & Resultados \\
\hline $\begin{array}{l}\text { 1. Mezclar de } 5 \mu \mathrm{L} \text { de } \mathrm{DAO}^{\mathrm{a}}(60 \text {, } \\
110,120 \mathrm{mg} \text { de } \mathrm{DAO} / \mathrm{mL} \text { de } \\
\text { tampón fosfato } 100 \mathrm{mM}, \mathrm{pH} \\
\text { 7.2) con } 5 \mu \mathrm{L} \text { de glutaraldehído } \\
\text { (2 y } 2.5 \%) \text {. Secar al aire durante } \\
45 \mathrm{~min} \text {. Lavar con glicina ( } 100 \\
\mathrm{mM} \text { y y tampón fosfato } \\
(100 \mathrm{mM}, \mathrm{pH} 7.2 \text { ). }\end{array}$ & $\begin{array}{l}\text { - A altas concentraciones de enzima y glutaraldehído. } \\
\text { La polimerización ocurre muy rápido, es imposible } \\
\text { forma un gel consistente. } \\
\text { - A bajas concentraciones de enzima y glutaraldehído. } \\
\text { Se obtienen mezclas homogéneas si estas se realizan } \\
\text { muy rápido. La mezcla se puede depositar sobre la } \\
\text { membrana; sin embargo, después del secado se } \\
\text { forma una película muy fina que impide la difusión } \\
\text { total del oxígeno a través de ella, obteniendo } \\
\text { señales de corriente muy bajas. La reproducibilidad } \\
\text { de inyección y entre membranas es mínima. }\end{array}$ \\
\hline
\end{tabular}




\begin{tabular}{|c|c|}
\hline $\begin{array}{l}\text { 2. Depositar } 5 \mu \mathrm{L} \text { de DAO (110, } \\
120 \mathrm{mg} / \mathrm{mL} \text { ) sobre la } \\
\text { membrana, secar al aire } \\
\text { durante } 15 \text { min } \\
\text { posteriormente adicionar } 5 \mu \mathrm{L} \\
\text { de glutaraldehído (1 y } 2 \%) \text {. } \\
\text { Secar al aire durante } 30 \mathrm{~min} \text {. } \\
\text { Lavar con glicina }(100 \mathrm{mM}) \text { y } \\
\text { tampón fosfato }(100 \mathrm{mM}, \mathrm{pH} \\
\text { 7.2). }\end{array}$ & $\begin{array}{l}\text { - Altas y bajas concentraciones de enzima y } \\
\text { glutaraldehído. Al momento de añadir el } \\
\text { glutaraldehído sobre la gota de enzima, ésta emigró } \\
\text { hacia los bordes. La medición se realizó con la } \\
\text { enzima remanente del centro de la membrana. Se } \\
\text { detectó buena señal, pero la reproducibilidad entre } \\
\text { las membranas fue mínima y la operación fue muy } \\
\text { baja (6-10 inyecciones). La mejor respuesta se } \\
\text { obtuvo a una concentración de enzima de } 110 \\
\text { mg/mL y } 2 \text { \% de glutaraldehído. Incrementos } \\
\text { mínimos de enzima disminuyen la señal de } \\
\text { respuesta. }\end{array}$ \\
\hline
\end{tabular}

Notas: a) $5 \mu \mathrm{L}$ de enzima DAO de $110 \mathrm{mg} / \mathrm{mL}$ equivalen a $0.10 \mathrm{U} / \mathrm{mL}$

Los resultados obtenidos tras el desarrollo de estas experiencias, revelan el desgaste rápido de la DAO, posiblemente a causa de su baja actividad enzimática y/o que se haya desnaturalizado al momento de añadir el glutaraldehído. A fin de obtener mayor disponibilidad de enzima, la disolución enzimática (110 mg de $\mathrm{DAO} / \mathrm{mL}$ de tampón fosfato $100 \mathrm{mM}, \mathrm{pH} 7.2$ ) se pasó a través en un filtro de corte molecular de 100,000 Da en las condiciones descritas en el apartado 4.3.6.1. La DAO posee un peso molecular de 170,000 Da por lo que quedó retenida en el filtro y la disolución enzimática se concentró dos veces. La filtración además permitió limpiar la disolución enzimática, eliminando los compuestos (sales) o proteínas con pesos moleculares menores de 100,000 Da. En efecto, se detectó un 1.61 \% de proteína en el filtrado (según método descrito por Smith et al., 1985) y sulfato y amonio (detección rápida por cromatografía iónica). Además, para reducir la posible desnaturalización de la enzima por el glutaraldehído, el contacto de éste con la DAO se hizo de manera gradual sumergiendo la membrana enzimática durante $30 \mathrm{~s}$ en una disolución de glutaraldehído al 1 \% por el lado opuesto a donde se depositó la enzima. Así, con la enzima concentrada y libre de gran cantidad de impurezas se 
mejoró sustancialmente el proceso de inmovilización, se obtuvo más enzima disponible en el mismo volumen $(5 \mu \mathrm{L}, 0.2 \mathrm{U} / \mathrm{mL}$ ) y la señal de respuesta del sensor se incrementó.

Una vez se precisó el método de inmovilización se prosiguió a evaluar la operación de la membrana enzimática en el sensor. Como anteriormente se ha descrito, la enzima DAO exhibe mayor o menor actividad por algunas de las aminas biógenas, dependiendo de la fuente de extracción y/o la metodología de purificación (Tombelli y Mascini, 1998; Niculescu et al., 2001; Wimmerová y Macholán, 1999 y Frébort et al., 2000). En este sistema, la selectividad de la DAO comercial de riñón de cerdo (EC 1.4.3.6.) sobre las $A B$ se evaluó, inyectando directamente sobre la membrana enzimática $40 \mu \mathrm{L}$ del patrón de cada una de las aminas detectadas en los productos cárnicos, histamina (HI), putrescina (PU), cadaverina (CA), tiramina (TY), espermina (SM) y espermidina (SD), a una concentración de $0.01 \mathrm{mg} / \mathrm{mL}$ en tampón fostafo $100 \mathrm{mM}$, pH 7.2. La DAO mostró tener mayor afinidad por la $\mathrm{HI}$ al obtener la más alta señal de respuesta (Figura 26), seguida de la PU y la CA en un $39,7 \%$ y $18.5 \%$, respectivamente, si se considera del $100 \%$ la afinidad de la HI. Resultados similares fueron observados por Tombelli y Mascini, (1998). La TY, SM y SD no fueron sustrato de la DAO en estas condiciones, ya que produjeron una señal inferior a la corriente de fondo (línea recta mostrada en la Figura 26) generada en el sistema cuando se inyecta el tampón fosfato sin la adición de aminas. Sin embargo, la TY fue detectada a concentraciones mayores de $0.02 \mathrm{mg} / \mathrm{mL}$, no siendo así para la SM y SD. 


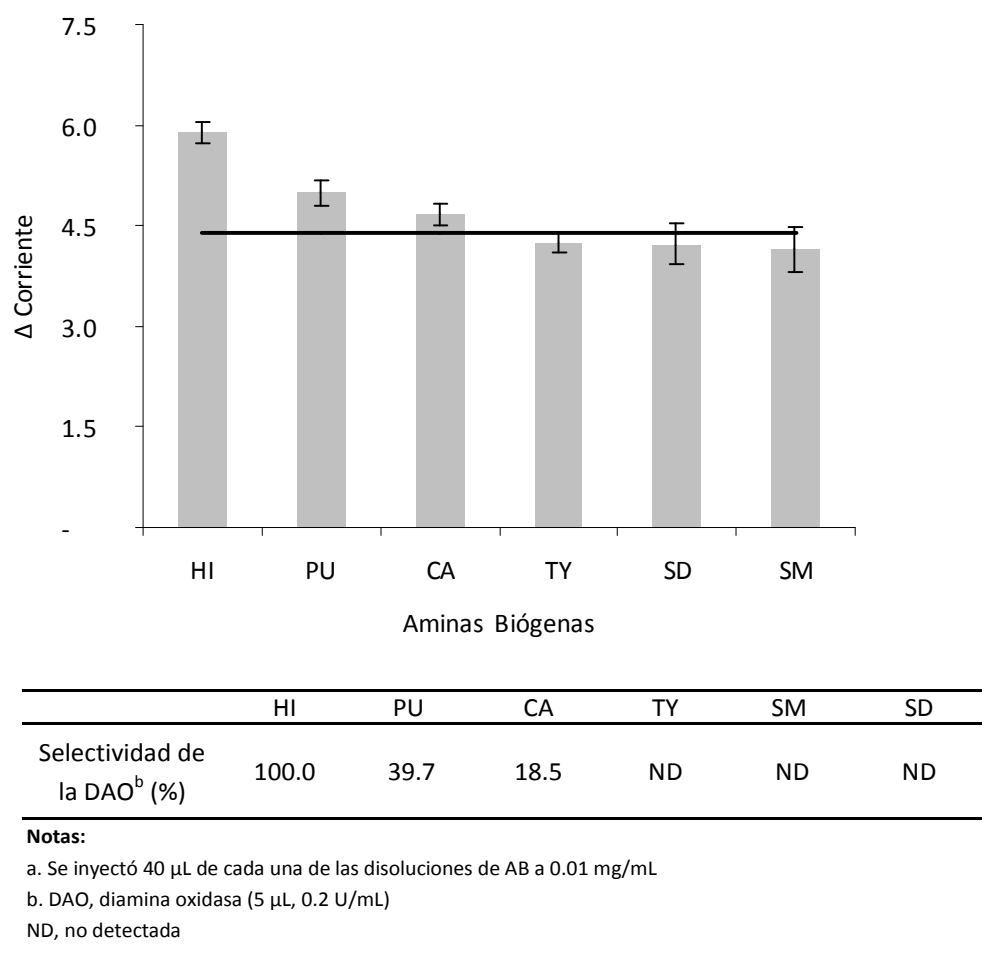

Figura 26. Evaluación de la selectividad de la diamina oxidasa (DAO) en el sensor enzimático con patrones de histamina (HI), putrescina (PU), cadaverina (CA), tiramina (TY), SD espermidina (SD), espermina (SM).

La actividad enzimática de la DAO es muy dependiente del pH como así lo han mencionado varios autores (Karube et al., 1980, Keow et al., 2007), siendo el pH óptimo diferente para las distintas $A B$. En este sentido, se evaluó el efecto del pH (entre 6.2 y 9.2 ) en la actividad catalítica de la enzima inmovilizada sobre $\mathrm{HI}$ y PU. EI pH optimó para la HI fue de 7.2 mientras que para la PU fue de 9.2 (Figura 27). Estos resultados coinciden con lo descrito por Karube et al., (1980), Yano et al., (1996), Bouvrette et al., (1997) y Keow et al., (2007), al encontrar que los cambios máximos de corriente para la mayoría de la aminas se encuentra en un intervalo de $\mathrm{pH}$ de 7.0 a 8.0. Para fines de este estudio se eligió el pH de 7.2 para las subsecuentes 
experiencias debido a que es el pH que se ha descrito como óptimo para la actividad catalítica de la DAO y a que los extractos cárnicos están en un intervalo entre 6.5 y 7.0 .

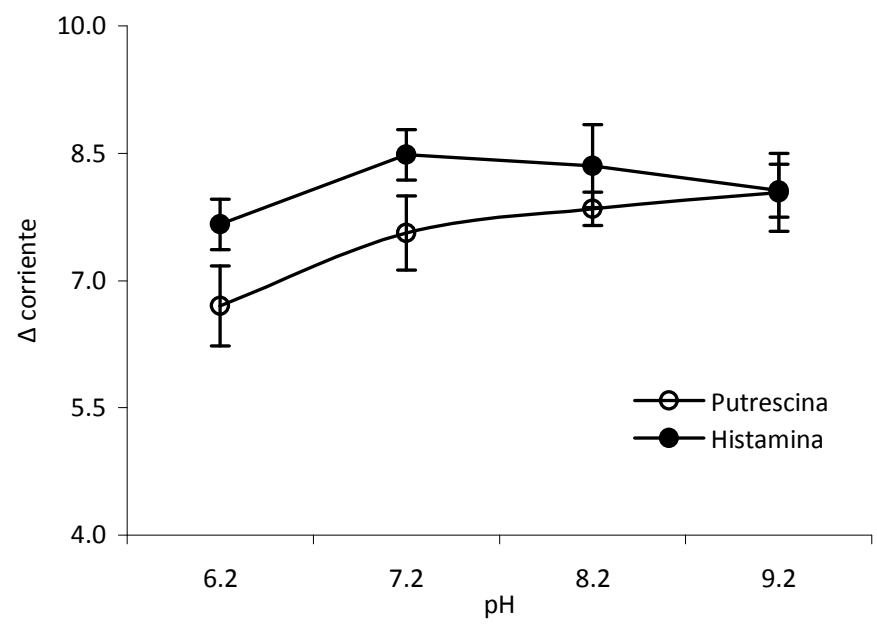

Figura 27. Efecto del pH sobre la señal de respuesta de la enzima diamina oxidasa inmovilizada en el sensor sobre la histamina y putrescina a una concentración de $0.02 \mathrm{mg} / \mathrm{mL}$ utilizando un tampón fosfato $100 \mathrm{mM}, \mathrm{pH} 7.2$ a $30^{\circ} \mathrm{C}$.

\section{Ensayos de validación}

En las condiciones experimentales elegidas anteriormente, se evalúo la linealidad de respuesta del sensor enzimático mediante la construcción de la recta de calibrado para $\mathrm{HI}$ (amina con mayor afinidad a la DAO) en tampón fosfato $100 \mathrm{mM}$, $\mathrm{pH}$ 7.2. a $30{ }^{\circ} \mathrm{C}$. El rango lineal fue de 0.005 a $0.04 \mathrm{mg} / \mathrm{mL}$. A fin de establecer las condiciones de medida similares a las del extracto cárnico de los productos curados, el patrón de $\mathrm{HI}$ se preparó con la disolución de extracción (ácido perclórico neutralizado). El intervalo de concentración en estas condiciones se mantiene, pero el cambio de corriente se incrementa, manteniendo la proporcionalidad de la recta. Sin embargo, cuando se analizaron los extractos cárnicos, los cambios de corriente no se ajustaron a ninguna de las rectas de calibrado, generando señales más altas, lo 
que indica que el efecto matriz influye drásticamente en la señal de medida. La composición de la matriz cambia a lo largo del proceso de curado en el sentido que, se van acumulando compuestos nitrogenados no proteicos o ácidos grasos libres que pueden interferir con la señal de medida. Además, la presencia simultánea de diversas aminas y su variada concentración contribuye también con esta desviación de medida, como así lo menciona Kivirand and Rinken, (2010). Esto, dificulta mucho la construcción de una recta de calibrado con adiciones sucesivas de patrón en una matriz especifica. Al intentar realizar una recta de calibrado para $\mathrm{HI}$ empleando extractos carnicos en estas condiciones los cambios de señal en el sensor fueron muy estrechos. En comparación con una curva de calibrado con matriz de carne fresca o pescado, donde las interferencias son menores y puede evaluarse la concentración de aminas totales o en miliequivalentes de $\mathrm{HI}$ como se ha mostrado en otros estudios (Karube et al., 1980; Carsol y Mascini, 1999) y puede observarse en la figura 28.

Aún así, el sensor enzimático fue capaz detectar diferentes niveles de concentración de aminas totales en los productos curados, como se describirá en el apartado 5.5., lo que permite que el sensor enzimático puede ser utilizado como una herramienta de exploración rápida o "screening". A concentraciones iguales o por debajo de $0.01 \mathrm{mg} / \mathrm{mL}$ de $A B$, la señal de respuesta se manifiesta con un pico al inicio de la inyección (Figura 28), indicando la ausencia de aminas biógenas detectables en la muestra. Por el contrario, un nivel alto de $A B$ totales ( $>0.06$ $\mathrm{mg} / \mathrm{mL}$ ) se manifiesta con una ligera disminución de la corriente seguida de un pico al final del tiempo de medida; lo que indica, que la muestra debe ser diluida para obtener una señal satisfactoria dentro del intervalo lineal. 


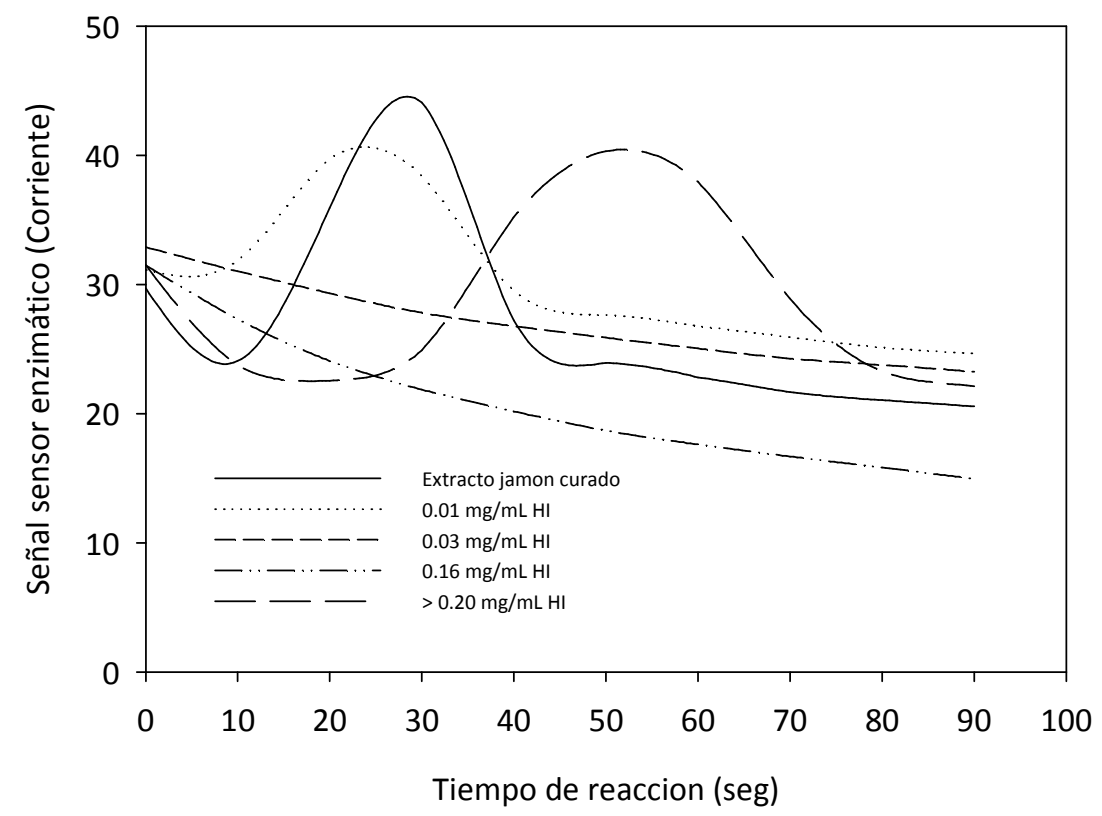

Figura 28. Respuesta del sensor enzimático de un extracto cárnico del músculo Semimembranosus de jamón ( $O$ días) enriquecido con patrón de histamina en ácido perclórico neutralizado a diferentes concentraciones a $30^{\circ} \mathrm{C}$.

La repetibilidad $(n=4)$, se calculó inyectando sucesivamente un patrón de histamina $(0.01 \mathrm{mg} / \mathrm{mL})$, un extractó cárnico de un embutido fermentado de 42 días de curado y un jamón de 11 meses de maduración, obteniendo un coeficiente de variación de 3.51, 5.39 y $4.01 \%$, respectivamente. Como es de esperarse, los productos curados presentan mayor variabilidad, debido a la propia composición de la matriz a esos niveles de curado.

Por otro lado, la membrana DAO se mantuvo estable durante las primeras 30 inyecciones realizadas a lo largo del día. Terminados los análisis del día, la membrana se almacenó a $4{ }^{\circ} \mathrm{C}$ en tampón fosfato $100 \mathrm{mM}, \mathrm{pH}$ 7.2. Al día siguiente de análisis, la sensibilidad disminuyó drásticamente y no fue posible reutilizar la membrana. Mientras, la estabilidad de membranas nuevas durante el 
almacenamiento a $4{ }^{\circ} \mathrm{C}$ resultó ser de 6 semanas sin observar disminución en la respuesta (Figura 29), con un coeficiente de variación entre las membranas del 1.73\%. Esta experiencia nos permitió ratificar la reproducibilidad de la inmovilización. A partir de la séptima semana la actividad de la membrana comenzó a disminuir en un $5.30 \%$ hasta alcanzar una pérdida de actividad del $10.89 \%$ en promedio a la octava semana; además, la variabilidad entre las mediciones en esa membrana fue muy alta y, ya no resultaba confiable su utilización.

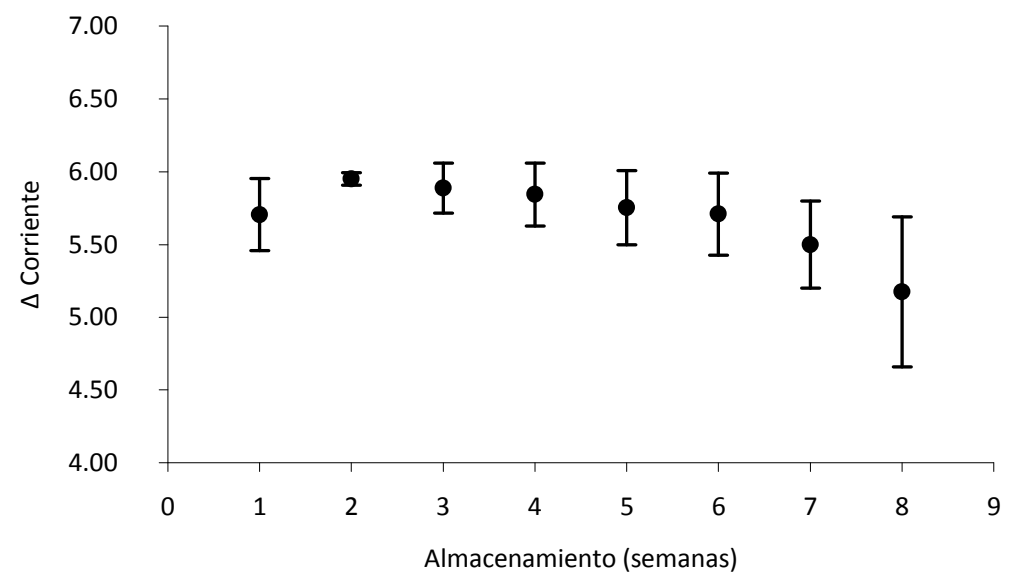

Figura 29. Estabilidad de la diamina oxidasa inmovilizada en almacenamiento a $4{ }^{\circ} \mathrm{C}$ en tampón fosfato $100 \mathrm{mM}, \mathrm{pH}$ 7.2. Las barras de error indican la desviación estándar de la medida de tres mediciones.

\subsection{Evolución de los nucleótidos y sus derivados analizados por HPLC en la carne y productos cárnicos.}

La calidad es un término descriptivo de gran importancia en la industria de la carne. Desde que el animal vivo es sacrificado, se transforma en carne y llega al consumidor, el factor calidad es cada vez más importante. A esto se le une el hecho de la extrema variabilidad que existe en la calidad de la carne de cerdo (PSE, RSE, RFN, DFD) y las considerables pérdidas económicas que esto conlleva (Scheffler y 
Gerrard, 2007). Ciertamente, inmediatamente después del sacrificio del animal, se inician en el músculo un gran número de cambios post-mortem que son críticos para definir el desarrollo de la calidad de la carne. El análisis de algunos metabolitos relacionados con la velocidad de glucólisis del músculo, ha sido propuesto como método rápido y simple para determinar la calidad de la carne. De estos, el análisis de nucleótidos a tiempos específicos post mortem ha sido uno de los métodos más exitosos (Batlle et al., 2001; Scheffler y Gerrard, 2007). Muchos autores han observado una correlación entre varios de estos metabolitos y la frescura en algunas especies de pecado (Jones et al., 1964; Luong y Male, 1992; Hattula y Kiesvaara, 1996), y la maduración y la calidad de la carne (Fujita et al., 1988; Yano et al., 1995; Batlle et al., 2001). Sin embargo, la evolución de estos compuestos y su correlación con la calidad en los productos cárnicos, no ha sido estudiada. En este contexto, se planteó el análisis de los nucleótidos y sus derivados durante la maduración de la carne y durante el proceso de curado del jamón y de un embutido fermentado, como a continuación se describe.

\subsubsection{Maduración de la carne.}

La conversión del músculo en carne, tras la muerte del animal, se produce en un periodo de varias horas y se caracteriza por la disminución de la temperatura del músculo, disminución del pH, agotamiento del ATP, establecimiento de la rigidez cadavérica o rigor mortis y finalmente de la resolución del rigor, denominada maduración. En esta última etapa, la carne experimenta un notable ablandamiento y las propiedades organolépticas se mejoran sustancialmente. El agotamiento del ATP, fuente principal de energía para mantener el músculo en un estado de relajación, es la causa principal del comienzo del rigor mortis. En ausencia de oxígeno el nivel de ATP depende de las reservas energéticas del músculo como la fosfocreatina (CP) y el glucógeno para regenerarse por vías metabólicas alternativas. Sin embargo, el saldo de estas reacciones finalmente resulta en una disminución gradual de ATP, que se 
degrada rápidamente a $A D P, A M P$ e IMP, y éste último a su vez se degrada a inosina y posteriormente a hipoxantina (Saito et al., 1959).

En vista de la importancia de los nucleótidos en el metabolismo energético y el interés de estos y de sus productos de degradación en la evaluación de la calidad, muchos estudios se han centrado durante las últimas décadas en el desarrollo de diferentes técnicas para separar, caracterizar y cuantificar estos compuestos (Aristoy y Toldrá, 2009). La cromatografía líquida de alta resolución (HPLC), debido a su versatilidad, tiempo de análisis y alta resolución es la técnica más utilizada para el análisis de nucleótidos y nucleósidos en muestras biológicas. Mas concretamente, la cromatografía líquida de alta resolución en fase reversa (RP-HPLC) (Veciana Nogués et al., 1997; Kuda et al., 2007), en RP-HPLC con par iónico (IP-RP-HPLC) (Murray y Thomson, 1983; Meynial et al., 1995; Veciana-Nogués et al., 1997) y HPLC de intercambio iónico (Lamb y Ye, 1992; Gao et al., 2006) han sido los métodos de elección para el análisis de estos compuestos durante décadas.

A pesar de que estas técnicas son muy poderosas, la cromatografía de interacción hidrofílica (HILIC) podría constituir una alternativa interesante para la separación de dichos compuestos (Alpert, 1990; Yoshida, 2004), dado el carácter iónico y polar de éstos. Esta técnica utiliza composiciones de fase móvil comparables a las empleadas en RP-HPLC con la consecuente ventaja sobre la solubilidad del analito y sin la necesidad de utilizar par iónico y/o reactivo de derivatización, lo que complica y aumenta el coste de los análisis. La tecnología, HILIC es un método interesante compatible con una posterior espectrometría de masas, ya que las fases móviles que se utilizan (disolventes orgánicos, agua y sales volátiles) son compatibles con ésta y se evitan pasos previos de desalinización cuando se utiliza otra técnica cromatográfica. 
En el presente trabajo, se ha utilizado la RP-HPLC con par iónico (IP-RP-HPLC) para la determinación de los nucleótidos y sus derivados y además se ha desarrollado un método alternativo basado en cromatografía líquida de interacción hidrofílica (HILIC). El método HILIC se ha optimizado y se han determinado los niveles de estos compuestos en muestras de lomo de cerdo en función del tiempo post-mortem $(5,7$, $9,11,27,51$ y 171 horas). Ambos métodos han sido comparados.

De esta manera, tras el análisis de pH a las 24 horas y la medida de drip loss en el músculo Longissimus dorsi de los lomos de cerdo seleccionados, se caracterizaron como músculos normales siguiendo el criterio adaptado por Flores et al., (1999 y 2000) ya que se obtuvieron valores dentro de los intervalos establecidos para este tipo de músculos $\left(\mathrm{pH}_{24}=5.63 \pm 0.03\right.$ y drip loss $\left.=3.5 \pm 0.04 \%\right)$. Las carnes PSE se caracterizan por un descenso rápido del $\mathrm{pH}_{2 \mathrm{~h}}(<5.6)$ y pérdidas por goteo mayores del $6 \%$, mientras que las carnes DFD mantienen su valor de $\mathrm{pH}$ inicial alto hasta las 24 horas post-mortem (> 6.0) con pérdidas por goteo menores del $3.0 \%$. Las carnes RFN presentan valores de $\mathrm{pH}$ intermedios entre 5.6 y 6.0 y pérdidas por goteo menores del $6 \%$.

\subsubsection{Evolución de nucleótidos y sus derivados por IP-RP-HPLC.}

Como método de referencia para la separación e identificación de los compuestos producto de la degradación del ATP durante la maduración de la carne cerdo se utilizó la IP-RP-HPLC en una columna Zorbax Eclipse XDB-C18 (150 × 4.6 mm, $5 \mu \mathrm{m})$ empleando como par iónico el $\mathrm{PIC}^{\circledR} \mathrm{A}$. El uso del par iónico incrementa la retención de los nucleótidos y mejora su resolución (Murray y Thomson, 1983), en efecto, permite la rápida detección de hipoxantina (Figura 30).

La figura 31 muestra la evolución de ATP y sus productos de degradación en el músculo (Longissimus dorsi) durante el proceso de maduración de la carne a $4{ }^{\circ} \mathrm{C}$. La 
concentración de ATP (Figura 31a) a las 5 horas post-mortem $(1.43 \pm 0.74 \mu \mathrm{mol} / \mathrm{g}$ ) coincide con los niveles detectados por Batlle et al., (2001), en este tipo de músculo y a ese tiempo post-mortem. En la misma figura puede observarse la degradación rápida del ATP, ya que a las 9 horas ha desaparecido casi en su totalidad. Este proceso coincide con lo mencionado por Batlle et al., (2001), indicando que la desaparición del ATP en músculos normales se llevó a cabo durante las primeras 8 horas mientras que en músculos exudativos fue a las 6 horas debido al metabolismo acelerado que presentan este tipo de carnes.

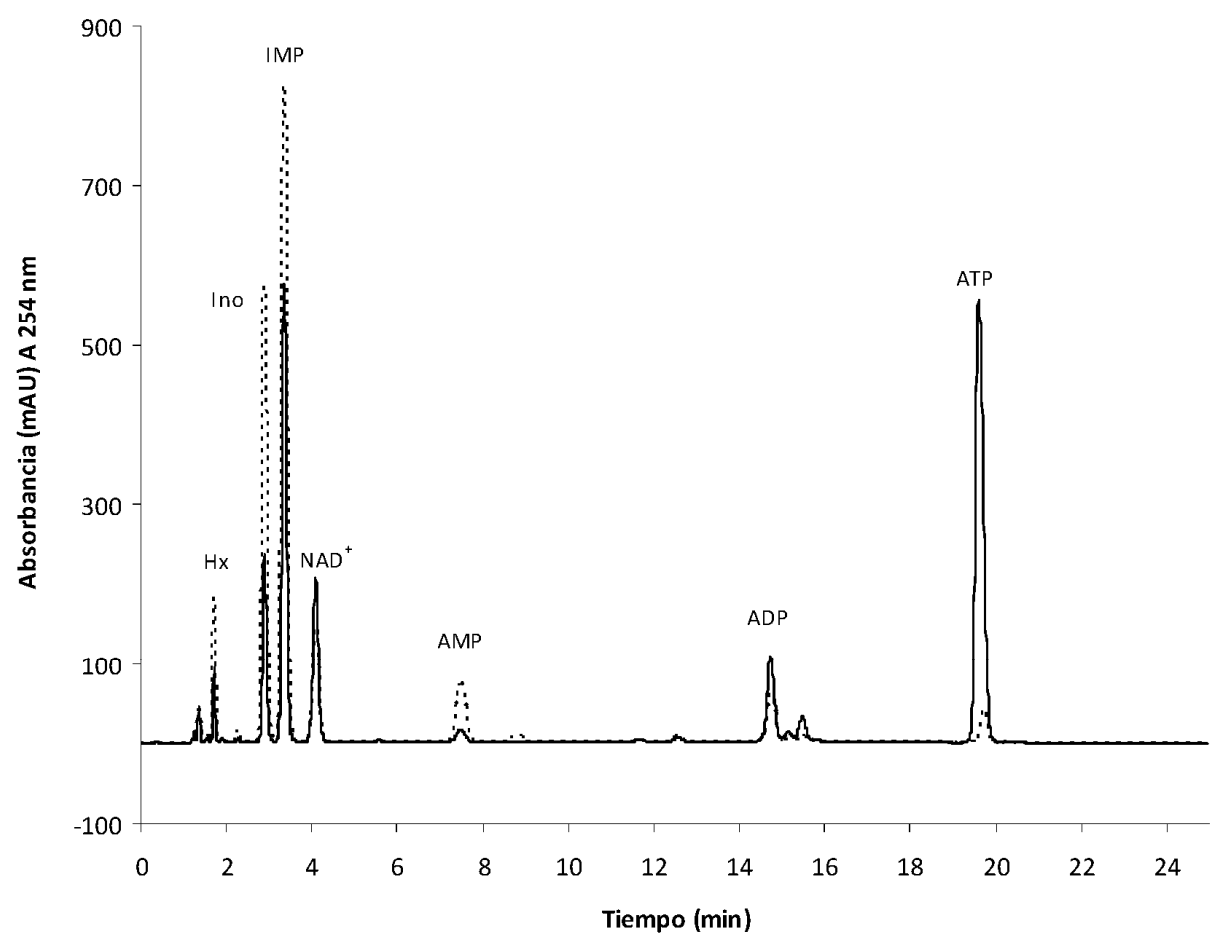

Figura 30. Cromatograma de IP-RP-HPLC correspondiente al análisis de muestras de carne de cerdo (Longissimus dorsi) a 5 (línea continúa) y 9 (línea quebrada) horas postmortem. Hipoxantina $(\mathrm{Hx})$, inosina (Ino), inosina 5' monofosfato (IMP), dinucleótido de nicotinamida adenina $\left(\mathrm{NAD}^{+}\right)$, adenosín monofosfato (AMP), adenosín difosfato (ADP) y adenosín trifosfato (ATP). En todos los casos la detección se realizó a $254 \mathrm{~nm}$. 
Como consecuencia del proceso anterior, el contenido de ADP $(0.86 \pm 0.21$ $\mu \mathrm{mol} / \mathrm{g}$ ), disminuye durante las 24 horas post-mortem sin llegar a su total desaparición, manteniéndose en un valor constante de $0.22 \pm 0.01 \mu \mathrm{mol} / \mathrm{g}$ a lo largo de la maduración (Figura 31b). El AMP (0.33 $\pm 0.10 \mu \mathrm{mol} / \mathrm{g})$ aumenta ligeramente en las primeras horas (de 5 a 7 horas) para luego comportarse de igual manera que el ADP hasta alcanzar valores de $0.24 \pm 0.01 \mu \mathrm{mol} / \mathrm{g}$ a las 24 horas (Figura 31c). Los niveles de AMP prácticamente se mantuvieron constantes durante todo el periodo evaluado debido posiblemente a que es un compuesto intermedio de la degradación.

El IMP, como producto de la degradación del ATP tiende a acumularse en las primeras horas hasta alcanzar un valor máximo de $7.30 \pm 0.45 \mu \mathrm{mol} / \mathrm{g}$ a las 24 horas, para después disminuir ligeramente (Figura 31d). Finalmente, los niveles de Ino e $\mathrm{Hx}$ aumentan con el tiempo (Figura 31e y 31f), alcanzando niveles de $2.10 \pm 0.49 \mu \mathrm{mol} / \mathrm{g}$ y $0.6179 \pm 0.13 \mu \mathrm{mol} / \mathrm{g}$, respectivamente, a los 171 horas post-mortem.

Asimismo, con este método cromatográfico se detectó el dinucleótido de nicotinamida adenina $\left(\mathrm{NAD}^{+}\right)$, el cual tiene una función vital en el metabolismo como coenzima que interviene en múltiples reacciones metabólicas de oxido-reducción (Figura $31 \mathrm{~g}$ ) y su concentración a las 5 horas post-mortem $(0.69 \pm 0.14 \mu \mathrm{mol} / \mathrm{g}$ ) va disminuyendo durante el proceso de maduración de la carne. Incluso, cantidades muy pequeñas de IMP y ribosa pueden generarse derivado del agotamiento del $\mathrm{NAD}^{+}$(Kassemsarn et al., 1963).

Cabe mencionar que los resultados obtenidos tras el análisis post-mortem en las muestras de carne de cerdo fueron muy similares a los publicados por otros autores en este tipo de muestras (Batlle et al., 2000 y 2001) lo que evidenció el comportamiento normal de los lomos elegidos para esta experiencia. 

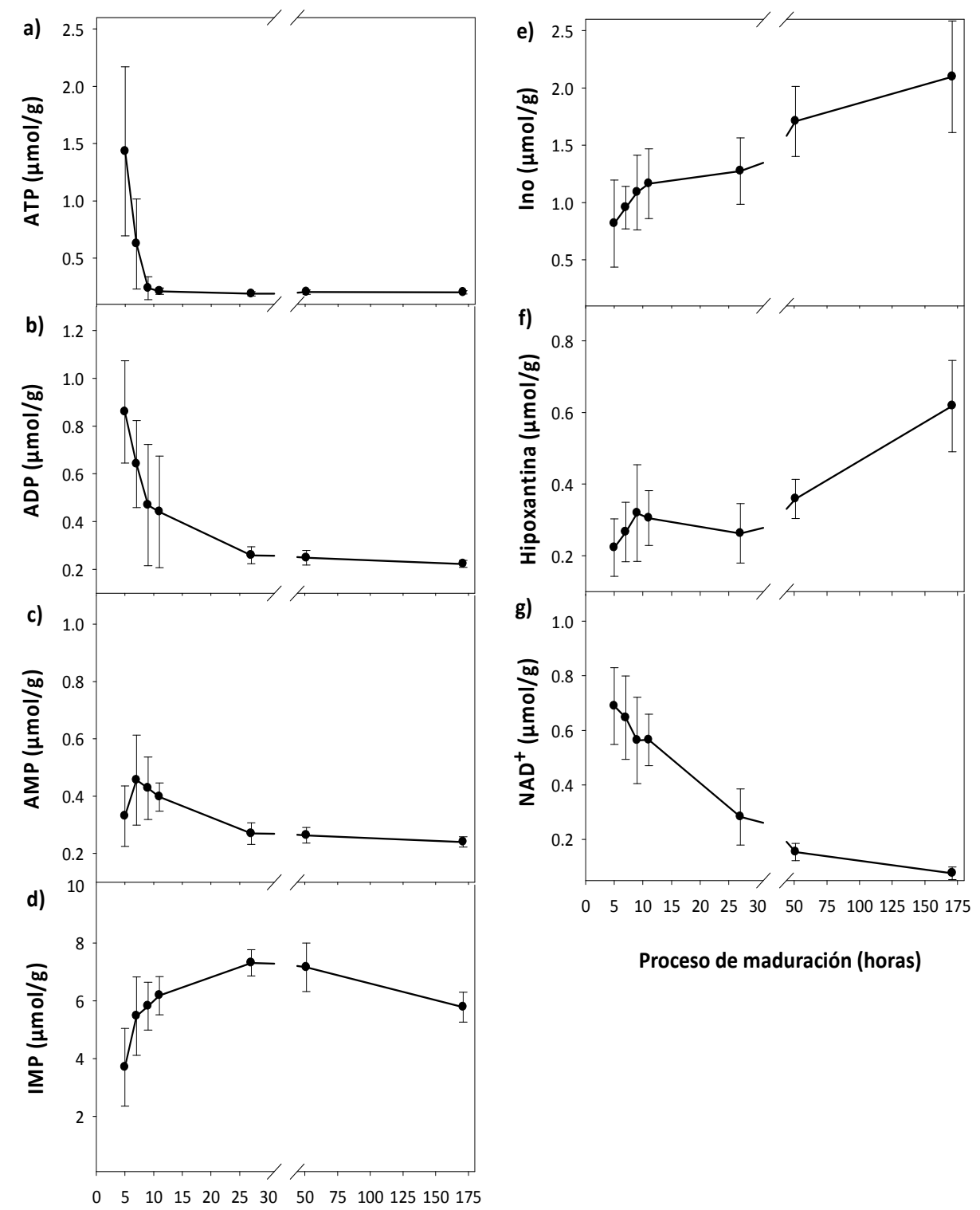

Proceso de maduración (horas)

Figura 31. Evolución de nucleótidos y sus derivados en el músculo Longissimus dorsi durante el proceso de maduración. Las barras de error indican la desviación estándar de la medida de cinco lomos. 


\subsubsection{Optimización del método cromatográfico HILIC.}

\subsection{Carne Fresca.}

Para establecer las condiciones óptimas de separación de ATP, ADP, AMP, IMP, Ino, $\mathrm{Hx}$ y $\mathrm{NAD}^{+}$por HILIC, se evalúo el efecto del disolvente orgánico, la concentración de sal y el pH en la fase móvil. En la cromatografía de tipo HILIC una cantidad elevada de disolvente orgánico en la fase móvil aumenta la retención de los analitos. Se eligió el acetonitrilo como disolvente orgánico por sus buenas características cromatográficas y su miscibilidad con agua, además, el ACN proporcionó buena solubilidad a los compuestos estudiados permitiendo la separación rápida de $\mathrm{Hx}$ e Ino (Figuras 32 y 33). El análisis cromatográfico se desarrollo utilizando una columna polimérica zwitteriónico ZIC ${ }^{\circledR}$-pHILIC (4.6 x 150 $\mathrm{mm}, 5 \mu \mathrm{m})$ junto con una precolumna $\mathrm{ZIC}^{\circledR}$-pHILIC $(2.1 \times 20 \mathrm{~mm}, 5 \mu \mathrm{m})$ y la separación se realizó empleando el gradiente que se muestra en la tabla 4.

Además, se ensayaron varios tipos de sales volátiles para determinar la más adecuada en cuanto a su solubilidad en el disolvente orgánico y su interacción con los compuestos estudiados. El acetato de amonio fue la sal de elección, ya que proporcionó los mejores resultados de selectividad y reproducibilidad, presentó excelente solubilidad, incluso a alta proporción de disolvente orgánico y es muy volátil, por lo que sería un tampón adecuado para un futuro análisis en espectrometría de masas. La concentración de sal y pH tienen un efecto importante en la retención y selectividad en cromatografía HILIC, influyendo en la ionización del analito. Ambos parámetros se optimizaron en la fase móvil. 
A)

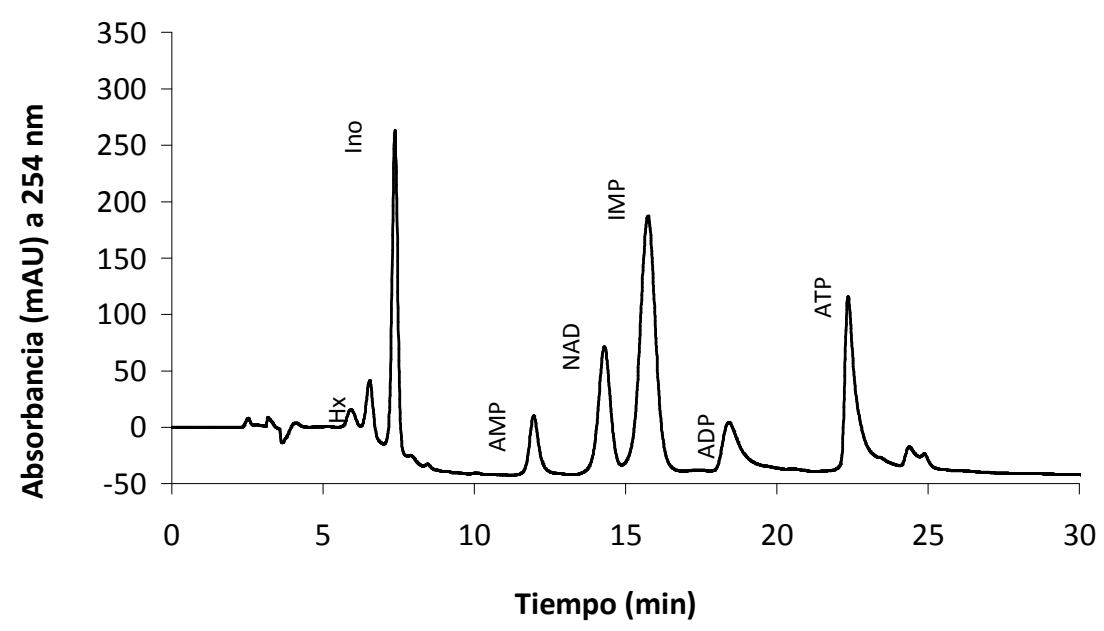

Figura 32. Cromatogramas correspondiente al análisis de muestras de carne de cerdo (Longissimus dorsi) a 5 horas (A) y a 27 horas (B) post mortem. Hipoxantina (Hx), inosina (Ino), adenosín monofosfato (AMP), dinucleótido de nicotinamida adenina $\left(\mathrm{NAD}^{+}\right)$, inosina 5' monofosfato (IMP), adenosín difosfato (ADP) y el adenosín trifosfato (ATP). En todos los casos se detectaron a $254 \mathrm{~nm}$.

Una buena separación de los patrones de los analitos estudiados se obtuvo con acetato de amonio $83.3 \mathrm{mM}$ a pH 7.0, aun así, en muestras de carne de cerdo, el pico de $\mathrm{Hx}$ coeluye con el pico identificado como creatinina (Cn). Para mejorar la separación de ambos compuestos se ensayaron diferentes $\mathrm{pH}$ y concentraciones de sal, obteniendo una separación aceptable empleando acetato amonio $112.5 \mathrm{mM}$ a $\mathrm{pH}$ 3.5. Por lo tanto, un acondicionamiento inicial de la columna a esa concentración y ph para luego realizar un gradiente como se refleja en la tabla 4 permitió la separación de la $\mathrm{Cn}$ y la $\mathrm{Hx}$, sin afectar a la selectividad y la resolución del resto de los picos como se muestra en la figura 33. 


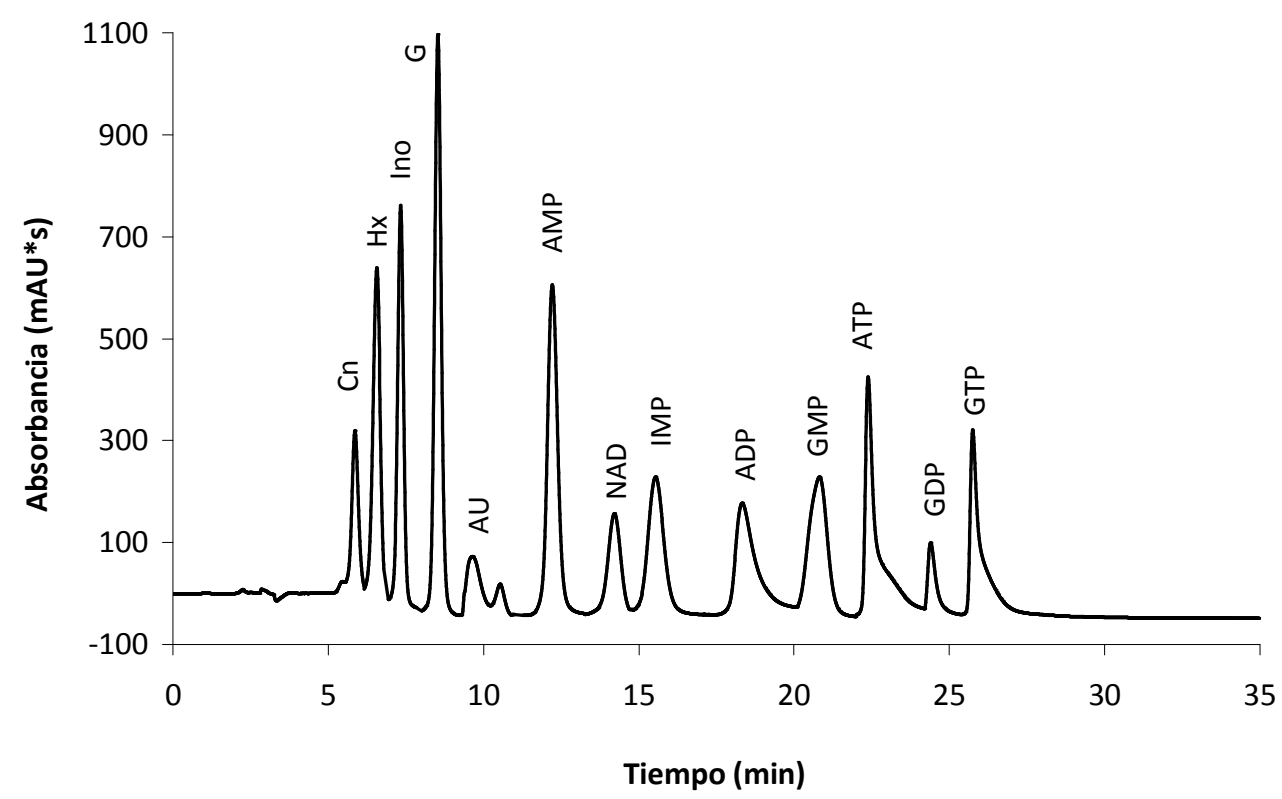

Figura 33. Cromatograma correspondiente a la separación de los patrones de los analitos estudiados junto con la creatinina $(\mathrm{Cn})$, ácido úrico $(\mathrm{AU})$, guanosina $(\mathrm{G})$, guanosín monofosfato (GMP), guanosín difosfato (GDP) y guanosín trifosfato (GTP).

El disolvente de inyección también es un parámetro muy importante a considerar porque influye en la forma del pico. Una alta proporción de agua en el disolvente de inyección podría resultar en una menor retención, poca eficiencia y una peor separación de los compuestos pero, por otra parte, los nucleótidos no pueden ser fácilmente disueltos en disoluciones altamente orgánicas. Así que los compuestos estudiados se lograron solubilizar utilizando una disolución al $50 \%$ de ACN y ácido perclórico 0.6 M neutralizado con carbonato potásico (ver apartado 4.3.2.3) como disolvente de inyección. Con proporciones mayores de $A C N$ el $N A D^{+}$, el ADP y el ATP presentaron baja estabilidad.

Las condiciones cromatográficas descritas en la Tabla 4 dieron lugar a una buena separación de los siete compuestos estudiados como se puede observar en las 
figuras $32 \mathrm{a}$ y $32 \mathrm{~b}$. Otros metabolitos que participan en el metabolismo energético de la carne como la Cn (creatinina), AU, G (guanosina), GMP (guanosín monofosfato), GDP (guanosín difosfato) y GTP (guanosín trifosfato) se inyectaron junto con los compuestos estudiados obteniendo también una buena separación para todos ellos (Figura 33). El método cromatográfico desarrollado en este estudio no se validó para estos últimos compuestos porque su presencia en carne fresca es casi nula (Batlle et al., 2000). Sin embargo, la cantidad de $\mathrm{Cn}, \mathrm{AU}, \mathrm{G}, \mathrm{GMP}, \mathrm{GDP}$ y GTP en productos cárnicos curados, fermentados y cocidos es mayor y la importancia de algunos de éstos compuestos como la Cn o el GTP en la percepción del sabor de la carne ha sido estudiado (Macy et al., 1970; Cambero et al., 2000).

\section{Ensayos de validación del método cromatográfico HILIC}

Las rectas de calibración se construyeron mediante la utilización de diferentes intervalos de acuerdo a la concentración de cada analito en las muestras de carne. Las ecuaciones y los coeficientes de regresión de las rectas correspondientes a los respectivos analitos se muestran en la Tabla 17 . La respuesta fue lineal en el intervalo de concentración estudiado en todos los analitos con coeficientes de regresión superiores a 0.99. La linealidad del método para todos los compuestos es tan buena como la obtenida con otros métodos.

Tabla 17. Tiempos de retención y rectas de calibración obtenidos en el análisis de los patrones de hipoxantina $(\mathrm{Hx})$, inosina (Ino), adenosín monofosfato (AMP), dinucleótido de nicotinamida adenina $\left(\mathrm{NAD}^{+}\right)$, inosina $5^{\prime}$ monofosfato (IMP), adenosín difosfato (ADP) y adenosín trifosfato (ATP). 


\begin{tabular}{|c|c|c|c|c|c|c|c|}
\hline \multirow{2}{*}{ Analito } & \multirow{2}{*}{$\begin{array}{l}\text { Tiempo de } \\
\text { retención } \\
(\mathrm{min})\end{array}$} & \multirow{2}{*}{$\begin{array}{l}\text { Intervalo } \\
(\mu \mathrm{g} / \mathrm{mL})\end{array}$} & \multicolumn{2}{|c|}{ Pendiente } & \multicolumn{2}{|c|}{ Ordenada en el origen } & \multirow[b]{2}{*}{$R^{2}$} \\
\hline & & & Media* & SD & Media* & SD & \\
\hline $\mathrm{Hx}$ & 6.5 & $0.5-100$ & 158488.8 & 2711.1 & 38.6 & 7.5 & 0.999 \\
\hline INO & 7.3 & $1-150$ & 80276.5 & 337.8 & 49.0 & 47.2 & 0.998 \\
\hline AMP & 11.9 & $2-250$ & 67105.7 & 125.9 & -50.2 & 4.9 & 0.999 \\
\hline $\mathrm{NAD}^{+}$ & 14.4 & $3-350$ & 31569.2 & 220.5 & 71.8 & 3.3 & 0.997 \\
\hline IMP & 15.8 & $2-250$ & 40889.2 & 251.9 & -51.0 & 10.9 & 0.999 \\
\hline ADP & 18.6 & $2-300$ & 45553.9 & 1002.9 & -394.0 & 210.0 & 0.998 \\
\hline ATP & 22.5 & $3-400$ & 47802.5 & 740.5 & -558.6 & 138.1 & 0.999 \\
\hline
\end{tabular}

* Calculado a partir de tres rectas de calibrado representadas por la concentración $(\mathrm{mg} / \mathrm{mL})$ frente el área (mAU*s). Para cada analito se tomaron ocho puntos de referencia

El límite de detección (LD), obtenido a partir de enriquecimientos decrecientes de muestras de carne de 5 horas post-mortem y comparado con la señal ruido de una disolución blanco, (ver apartado 4.3.2.1.2.) fue de 1,72, 0,16, 0,05, 0,15, 0,16, 0,15 y $0,10 \mu \mathrm{g} / \mathrm{mL}$ para $\mathrm{Hx}$, Ino, AMP, NAD ${ }^{+}$, IMP, ADP y ATP, respectivamente (Tabla 18). Como puede observarse, el límite de detección de la hipoxantina fue considerablemente más alto que el del resto de los analitos debido al incremento de la absorción a $254 \mathrm{~nm}$ en esa zona ( $6.5 \mathrm{~min}$ ) causadas por el gradiente de sal que provoca alteraciones de la línea base del cromatograma. Los datos de repetibilidad y reproducibilidad, que se muestran en la tabla 18, demostraron muy poca variabilidad de un análisis a otro. Los resultados coinciden con los publicados por otros autores para músculos de cerdo de 5 horas post-mortem que se habían analizado utilizando otros métodos (Tsai et al., 1972; Batlle et al., 2000 y 2001).

Tabla 18. Limite de detección (LD), repetibilidad y reproducibilidad calculados en muestras de lomo de cerdo de 5 horas post-mortem. 


\begin{tabular}{|c|c|c|c|c|c|c|c|c|}
\hline \multirow{2}{*}{ Analito } & \multicolumn{2}{|c|}{$\operatorname{LD}(n=20)$} & \multicolumn{3}{|c|}{ Repetibilidad ( $n=8)$} & \multicolumn{3}{|c|}{ Reproducibilidad $(n=6)$} \\
\hline & Media $(\mu \mathrm{g} / \mathrm{mL})$ & DS & Media $(\mathrm{mg} / 100 \mathrm{~g})$ & DS & $\mathrm{CV}$ & Media (mg/100g) & DS & $\mathrm{CV}$ \\
\hline $\mathrm{Hx}$ & 1.72 & 0.10 & 3.04 & 0.03 & 1.00 & 3.04 & 0.02 & 0.77 \\
\hline Ino & 0.16 & 0.03 & 24.19 & 0.13 & 0.55 & 24.31 & 0.32 & 1.33 \\
\hline AMP & 0.05 & 0.01 & 10.22 & 0.10 & 0.98 & 10.09 & 0.23 & 2.32 \\
\hline NAD & 0.15 & 0.01 & 59.85 & 0.73 & 1.22 & 55.88 & 5.31 & 9.50 \\
\hline IMP & 0.16 & 0.01 & 130.79 & 0.77 & 0.59 & 128.69 & 2.10 & 1.64 \\
\hline ADP & 0.15 & 0.01 & 42.17 & 0.37 & 0.88 & 39.15 & 3.00 & 7.66 \\
\hline ATP & 0.10 & 0.01 & 104.10 & 0.40 & 0.39 & 104.26 & 0.75 & 0.72 \\
\hline
\end{tabular}

El porcentaje de recuperación determinado después de la adición de cantidades conocidas de patrón de los analitos a muestras de carne de 5 horas post- mortem, se muestran en la tabla 19 y osciló entre el 94.8 y el $121.6 \%$.

\section{Comparación entre el método IP-RP-HPLC e HILIC.}

Las muestras de carne de cerdo a diferentes tiempos post-mortem se analizaron simultáneamente tanto por HILIC como por IP-RP-HPLC utilizando las columnas descritas en el apartado 4.3.2. para determinar la concentración ATP, ADP, AMP, IMP, Ino, $\mathrm{Hx}$ y NAD ${ }^{+}$. El análisis de varianza no reveló diferencias significativas entre los datos obtenidos en ambas columnas para casi todos los compuestos y tiempos post-mortem, aunque a las 171 horas en $\mathrm{NAD}^{+}$y a 27,51 y 171 horas en ADP se observaron diferencias significativas $(p<0.01)$.

Tabla 19. Recuperación de los analitos estudiados en muestras de lomo de cerdo de 5 horas post-mortem. 


\begin{tabular}{|c|c|c|c|c|c|}
\hline \multirow[t]{2}{*}{ Analito $^{a}$} & Muestra $^{b}$ & $\begin{array}{c}\text { Valor } \\
\text { añadido }\end{array}$ & Valor teórico $^{c}$ & $\begin{array}{c}\text { Valor } \\
\text { recuperado }\end{array}$ & \multirow{2}{*}{$\begin{array}{c}\text { Recuperación } \\
\text { (\%) }\end{array}$} \\
\hline & \multicolumn{4}{|c|}{$(\mathrm{mg} / 100 \mathrm{~g})$} & \\
\hline \multirow{3}{*}{$\mathrm{Hx}$} & & 2.85 & 6.08 & 6.07 & 99.71 \\
\hline & 3.23 & 5.70 & 8.93 & 8.67 & 97.05 \\
\hline & & 11.40 & 14.63 & 14.19 & 96.98 \\
\hline \multirow{3}{*}{ Ino } & & 11.25 & 35.91 & 35.23 & 98.11 \\
\hline & 24.66 & 22.50 & 47.16 & 46.30 & 98.16 \\
\hline & & 45.00 & 69.66 & 69.52 & 99.80 \\
\hline \multirow{3}{*}{ AMP } & & 5.21 & 15.83 & 17.60 & 111.20 \\
\hline & 10.66 & 10.42 & 21.04 & 24.36 & 115.79 \\
\hline & & 20.85 & 31.46 & 38.26 & 121.60 \\
\hline \multirow{3}{*}{$\mathrm{NAD}^{+}$} & & 10.80 & 54.55 & 61.98 & 113.62 \\
\hline & 43.94 & 21.60 & 65.35 & 69.20 & 105.88 \\
\hline & & 43.20 & 86.95 & 84.49 & 97.16 \\
\hline \multirow{3}{*}{ IMP } & & 58.50 & 192.15 & 189.81 & 98.78 \\
\hline & 133.65 & 117.00 & 250.65 & 248.36 & 99.09 \\
\hline & & 234.00 & 367.65 & 371.58 & 101.07 \\
\hline \multirow{3}{*}{ ADP } & & 22.50 & 72.57 & 70.79 & 97.54 \\
\hline & 50.07 & 45.00 & 95.07 & 97.83 & 102.89 \\
\hline & & 90.00 & 140.07 & 145.01 & 103.52 \\
\hline \multirow{3}{*}{ ATP } & & 62.55 & 166.44 & 158.58 & 95.28 \\
\hline & 103.89 & 125.10 & 228.99 & 217.09 & 94.80 \\
\hline & & 250.20 & 354.09 & 341.43 & 96.43 \\
\hline
\end{tabular}

a Hipoxantina ( $\mathrm{Hx}$ ), inosina (Ino), adenosín monofosfato (AMP), dinucleótido de nicotinamida adenina $\left(\mathrm{NAD}^{+}\right)$, inosina $5^{\prime}$ monofosfato (IMP), adenosín difosfato (ADP) y adenosín trifosfato (ATP)

${ }^{b}$ Cada valor corresponde con tres repeticiones en cada nivel de concentración.

${ }^{\mathrm{c}}$ El valor teórico contempla el valor añadido mas el intrínseco de la muestra

Por otro lado, en la figura 34 se ilustra la correlación entre los datos obtenidos por HILIC y el método IP-RP-HPLC. Se encontró una buena correlación entre los dos conjuntos de datos con coeficientes de correlación de 0.99 para el ATP, ADP, AMP, $\mathrm{Hx}$ y $\mathrm{NAD}^{+}$y 0.94 para IMP e Ino. Estos resultados demuestran la precisión y fiabilidad de ambos métodos utilizando estas columnas.
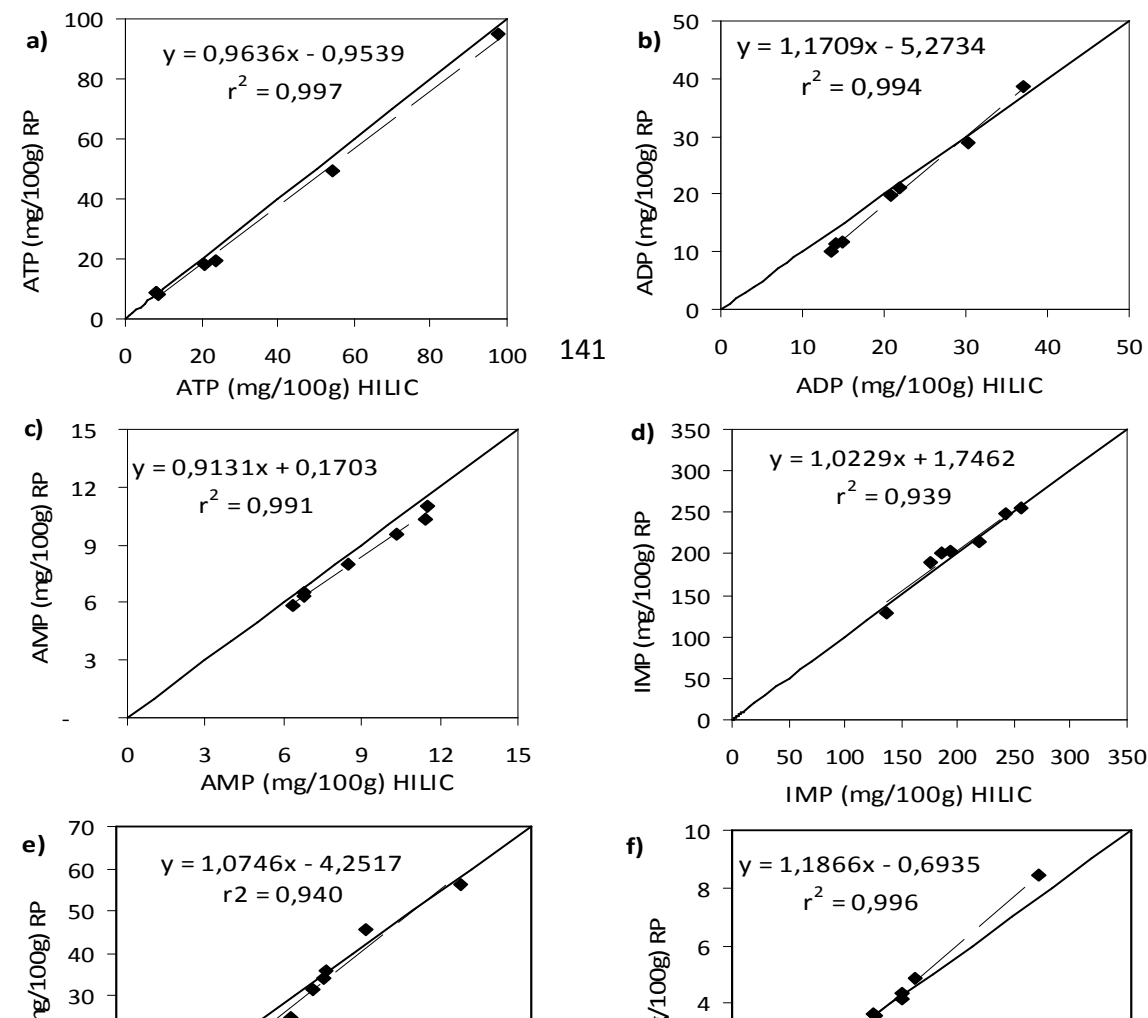
Figura 34. Correlación entre el método HILIC y el método IP-PR-HPLC con respecto a las concentraciones de los analitos estudiados. La línea continua indica la correspondencia perfecta $(\mathrm{x}=\mathrm{y})$ y la línea quebrada las correlaciones obtenidos tras el análisis.

\subsection{Productos cárnicos.}


En el caso de los productos cárnicos como el jamón curado, la acción de las enzimas es bastante más pronunciada que en otros productos debido al largo tiempo de elaboración y maduración, dando lugar a una gran la cantidad de péptidos y aminoácidos libres (Toldrá, 1998; Bolumar et al., 2001) que generan interferencias con los analitos de estudio cuando se analizan por IP-PR-HPLC.

Como se ha mencionado en al apartado anterior, HILIC constituye un método válido y fiable para analizar el ATP y sus metabolitos. La fase estacionaria elegida en este método contiene grupos funcionales zwitteriones altamente polarizados que resultan muy adecuados para la separación y cuantificación de estos compuestos en matrices complejas como la carne fresca. En general la metodología de análisis HILIC resultó ser una técnica simple en comparación con otros métodos convencionales, ya que evita limpiezas complejas o procedimientos de derivatización de la muestra y, además, es compatible con el análisis de espectrometría de masas en caso que se necesitara.

En este contexto, se inyectó un extracto de un jamón curado de 11 meses de maduración en las condiciones cromatográficas HILIC propuestas. En la figura 35 se muestra la separación de los compuestos de interés. Aún cuando se observa una excelente separación de algunos de ellos, la Hx y la X coeluye. Razón por la cual, se propuso la utilización de la RP-HPLC descrita en el apartado 4.3.2.2.1., cuyos resultados se muestran y discuten en el apartado 5.2.3. Cabe mencionar que los resultados obtenidos, derivados del análisis cromatográfico de la carne fresca, jamón curado, formaron parte de una revisión sobre las aplicaciones recientes de la metodología HILIC en el análisis de compuestos bioquímicos relacionados con la calidad y seguridad en la carne, pollo y productos procesados (Anexo 3).

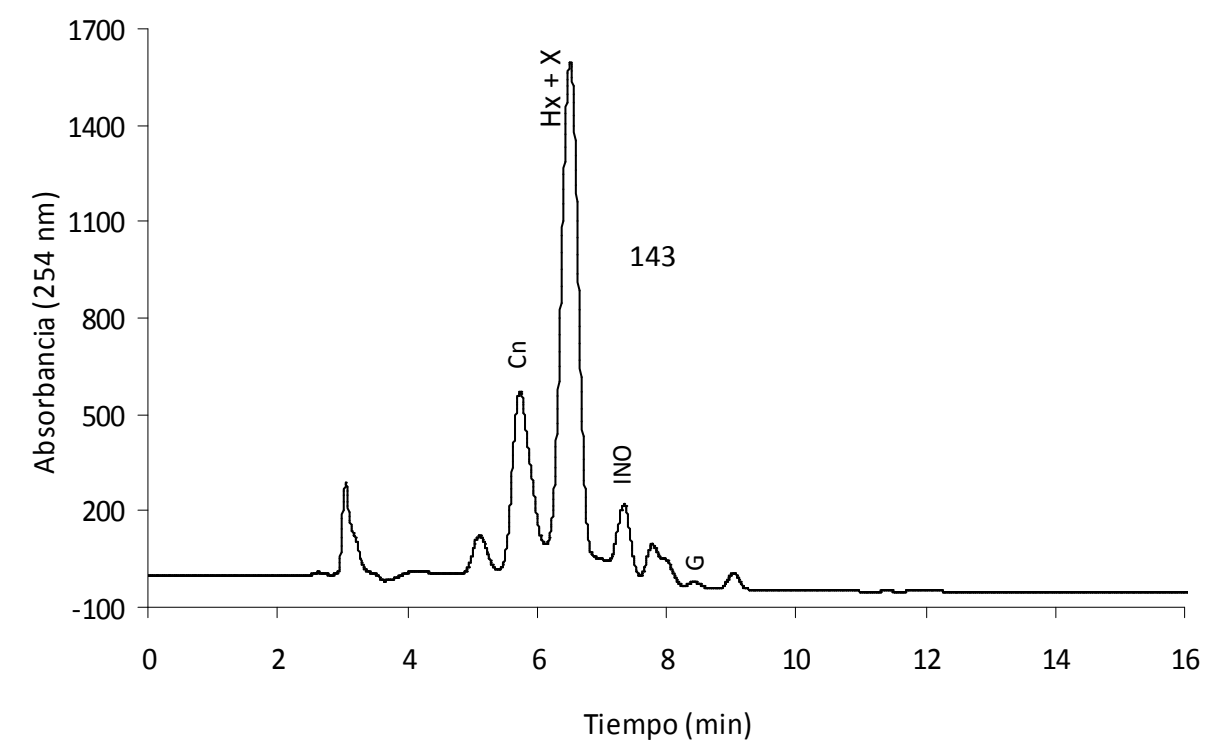


Figura 35. Cromatograma correspondiente al análisis de jamón curado de 11 meses por HILIC usando una columna ZIC-pHILIC (Sequant, 4.6 x $150 \mathrm{~mm}, 5 \mu \mathrm{m})$. Cn (creatinina), $\mathrm{Hx}+\mathrm{X}$ (hipoxantina+xantina), Ino (inopina), G (guanosina).

\subsubsection{Proceso de curado de un embutido fermentado.}

Los embutidos fermentados curados constituyen un grupo de productos tradicionales del área mediterránea muy apreciados por los consumidores europeos. La tecnología de fabricación de estos productos ofrece una multitud de posibilidades y variantes en cuanto a ingredientes y procesos de elaboración, lo que ha dado lugar a la aparición de gran número de variedades nacionales, regionales e incluso locales. En general, las características de la materia prima, las condiciones en las que se lleva acabo el proceso, el efecto de las especias, los agentes de curado y la adición de cultivos iniciadores aunado a complejas transformaciones químicas y enzimáticas (autolítica y/o microbianas) definen las características organolépticas del producto final así como su conservación y seguridad.

En particular, los microorganismos desempeñan un papel importante en estos productos, ya que están directamente implicados en la reducción de nitratos a 
nitritos, el descenso de $\mathrm{pH}$, la formación del aroma, la estabilidad del color y la capacidad de conservación. La inoculación con cultivos iniciadores mejora la calidad y la seguridad del producto final al inhibir y/o controlar el crecimiento de poblaciones dañinas, además de permitir la estandarización del los procesos de producción. La combinación de condiciones controladas de secado y del uso de cultivos iniciadores ha permitido de cierta manera remplazar la lenta tecnología tradicional de fabricación por maduraciones rápidas aunque, generalmente, de menor calidad sensorial (Sanz et al., 1998)

El efecto del nitrito sobre los productos curados que ha sido ampliamente estudiado, se resume en que contribuye en la formación del color rojo típico de la carne curada, en la inhibición del crecimiento del Clostridium botulinum, en el desarrollo del aroma a curado además de ejercer un efecto antioxidante retrasando el enranciamiento por oxidación (Flores y Toldrá, 1993). Sin embargo, el uso de nitrato como sal de curado ofrece ciertas ventajas tecnológicas sobre todo cuando se emplea en procesos tradicionales de curado con bajas temperaturas y tiempos de secado largos, actuando como reservorio y reduciéndose lentamente a nitrito (Toldrá, 2005); incluso, el uso de nitrato mejora el sabor y aroma de los embutidos (Sanz et al., 1998; Olivares et al., 2009).

En años recientes, a fin de facilitar la distribución, aumentar la vida útil y la venta al por menor de productos cárnicos fermentados curados en formatos atractivos para el consumidor (lonchas), varios autores (Fernández et al., 2001) han estudiado el efecto del envasado sobre la calidad y variedad de embutidos. El envasado en atmósferas modificadas (al vacío o con gases) detiene la desecación ulterior y reacciones de oxidación intensas, y por ello es muy beneficioso cuando se quiere alargar la vida del embutido (Róncales., 1994). 
En este trabajo se estudió el efecto que tiene la fabricación de embutidos fermentados curados con nitrito o nitrato, como agentes de curado, sin la adición de especias en un proceso de fermentación lenta sobre los cambios de nucleótidos y sus derivados. Los resultados obtenidos se describen a continuación.

\subsubsection{Evolución de los parámetros fisicoquímicos}

Las condiciones de temperatura durante el proceso, pérdidas de peso y humedad se muestran en las figura 36. La evolución de estos parámetros podría considerarse como normales para este tipo de productos y proceso (fermentación lenta) al coincidir con los datos obtenidos por otros autores (Marco et al., 2006; Olivares et al., 2009). La pérdida de peso se determinó a lo largo del proceso de curado (42 días) en ambos lotes, alcanzado en promedio una pérdida del $40.29 \%$ sin encontrar diferencia importantes entre ellos y coincidiendo con la pérdida de humedad de las muestras desde 62.26 \% hasta 38.39 y $40.22 \%$ para los lotes de nitrito y nitrato, respectivamente, manteniéndose prácticamente constante hasta el final de la etapa de envasado al vacío.

Con el fin de controlar el proceso de fermentación y obtener un producto homogéneo, durante el proceso de fabricación se adicionó el cultivo comercial SP318 (Ver apartado 4.2.2), que contenía una mezcla homogénea de Lactobacillus sakei, Pediococcus pentosaceus, Staphylococcus xylosus y Staphylococcus carnosus. 


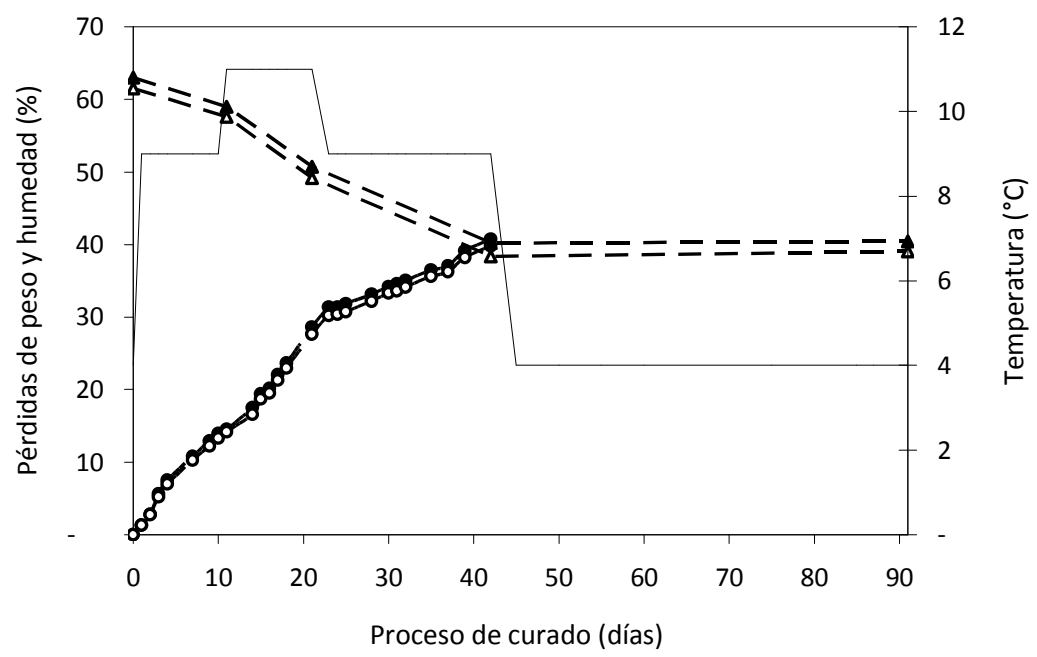

Figura 36. Evolución de las pérdidas de peso (nitrito (०) nitrato $(\bullet)$ ) contenido de humedad (nitrito $(\triangle)$ nitrato $(\mathbf{\Delta})$ ) y temperatura (línea continua) durante el proceso de curado de los embutidos fermentados.

De esta manera, la evolución de la población de bacterias lácticas (BAL) y estafilococos durante el proceso de curado se muestra en la figura 37. Los resultados se encontraron dentro de los intervalos esperados en este tipo de productos (Marco et al., 2006). Se observó un crecimiento rápido de las BAL durante los primeros 11 días correspondientes a la etapa de fermentación, en ambos lotes, ratificado por la disminución rápida del pH (Figura 37) debida a la producción de ácido láctico como producto final de la fermentación de carbohidratos. No se mostraron diferencias significativas $(p<0.05)$ en relación al $\mathrm{pH}$ entre ambos lotes. Durante la etapa de maduración se observa un ligero aumento de la población en ambos lotes, que es ligeramente superior en el lote de nitritos encontrando diferencia significativas $(p<0.05)$ con el lote de nitratos. A partir de aquí la población de BAL se mantuvo constante hasta el final del envasado en ambos lotes mientras que el pH aumentó ligeramente. 


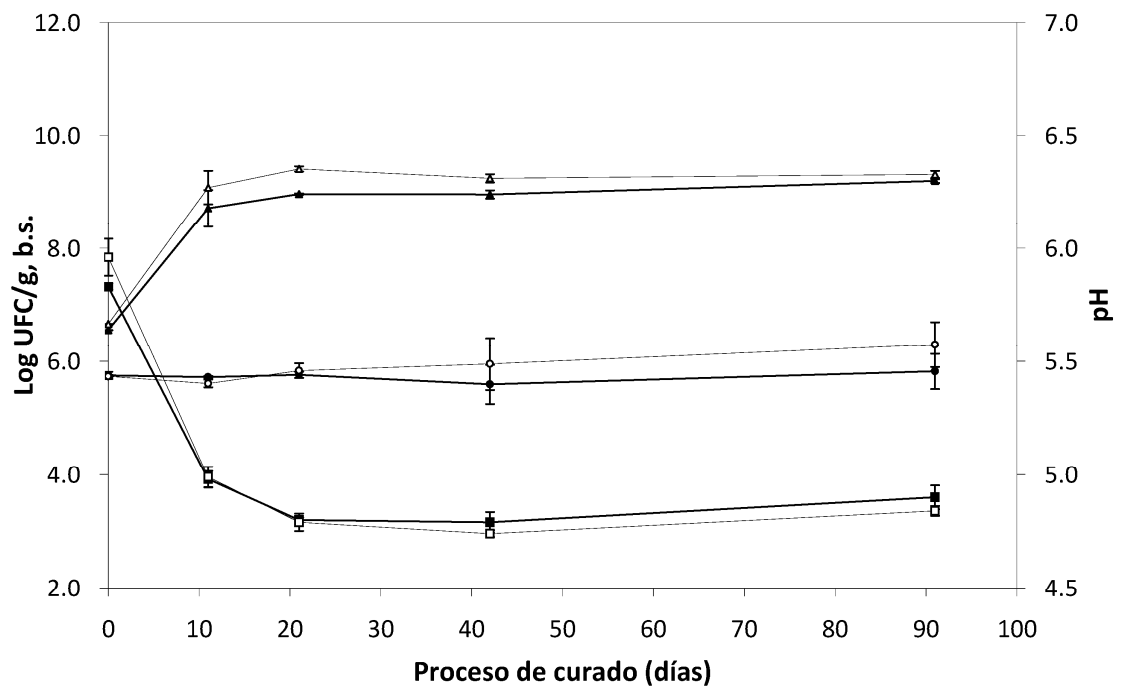

Figura 37. Población de estafilococos (nitrito $(\circ)$ nitrato $(\bullet)$ ), bacterias ácido lácticas (nitrito $(\triangle)$ nitrato $(\mathbf{\Delta})$ ) y evolución del pH ( $\square$ nitrito y $\square$ nitrato) durante el proceso de curado de los embutidos fermentados. Las barras de error indican la desviación estándar de la media de tres embutidos.

La población de estafilococos tanto en el lote de nitrito como en el de nitrato mostró tasas de crecimiento muy similares, manteniéndose constantes a lo largo del proceso de curado y envasado. Aunque, no se muestran diferencias significativas $(p<0.05)$ entre los lotes, se observa un ligero incremento en el lote de nitrito. El crecimiento de estos microorganismos se ve inhibido por la reducción de $\mathrm{pH}$ (Hammes et al., 2003). La adición de estos microorganismos es importante por su actividad nitrato reductasa que es la responsable de la reducción del nitrato a nitrito, estabilización del color típico del embutido, actividad catalasa y prevención de la rancidez y por su implicación en la hidrólisis proteica para producir compuestos aromáticos que mejoran las propiedades sensoriales del producto (Montel et al., 1998). 


\subsubsection{Determinación de nucleótidos y sus derivados por RP-HPLC}

En este caso al igual que en jamón curado, la determinación de nucleótidos y sus derivados se realizó por cromatografía líquida en fase reversa (RP-HPLC) como se describe en el apartado 4.3.2.2. Esta técnica se eligió debido a la composición de la matriz cárnica, puesto que la cantidad de péptidos y aminoácidos libres aumentan a lo largo del proceso de curado (Toldrá, 1998; Bolumar et al., 2001), ocasionando interferencia con algunos de los compuestos de interés si fuesen analizados por IPPR-HPLC o HILIC, como se describe en apartado 5.2.1.1. y 5.2.1.2.2 respectivamente. En los productos curados puede aparecer xantina, producto de la oxidación de la $\mathrm{Hx}$ por vía autolítica en función del tiempo de curado o asociada a la presencia de flora microbiana (Urich, 1990), logrando una buena separación y cuantificación por RPHPLC (Figura 38). La determinación correcta de la hipoxantina y xantina será importante para su correlación con la obtenida mediante los sistemas enzimáticos propuestos en este trabajo (ver apartado 5.3.).

En los embutidos crudos fermentados se hizo el seguimiento de tres compuestos derivados de la degradación del ATP (IMP, Ino, Hx) y la creatinina (Cn), compuesto derivado de la conversión no enzimática de la creatina que constituye a su vez la fuente inmediata y directa para regenerar el ATP y proveer de energía a las células musculares. 


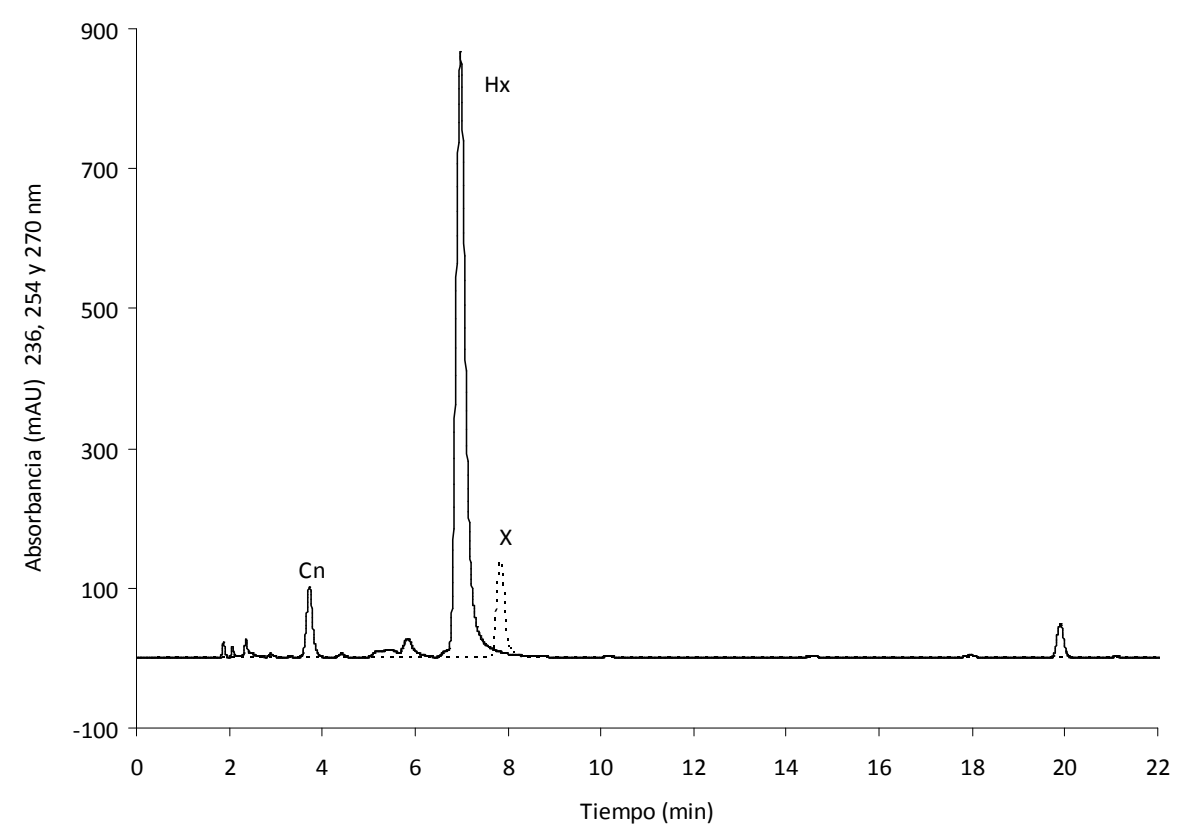

Figura 38. Cromatograma de RP-HPLC correspondiente al análisis de una muestra de un embutido fermentado de 24 días de curado (línea continua) y la separación del patrón de xantina (X) (línea quebrada). Creatinina $(\mathrm{Cn})$, hipoxantina $(\mathrm{Hx})$ y xantina (X). La detección se realizó a $236 \mathrm{~nm}, 254 \mathrm{~nm}$ y $270 \mathrm{~nm}$, respectivamente.

En la figura 39 se muestra la evolución de éstos durante el proceso de curado del embutido fermentado fabricado solo con nitrito o solo con nitrato. En general, a lo largo del proceso de curado (42 días) y envasado al vacío hasta los 91 días, no se detectaron diferencias significativas $(p<0.05)$ entre el lote de embutidos fabricado con nitrito o el fabricado con nitrato. Sin embargo, el contenido de IMP e Ino al final de la etapa de fermentación (11 días) mostró diferencias significativas $(p<0.05)$ entre ambos lotes. Los valores mas altos fueron detectados en las muestras con nitrito, dejando ver una ralentización en la degradación de dichos compuestos.

La concentración inicial de todos los compuestos detectados en ambos lotes muestra la utilización de una masa cárnica en una fase de maduración superior a las 
24 horas post-mortem según lo determinado en el análisis de carne fresca del apartado anterior; sin embargo, estos valores pueden estar influenciados en parte por la adición de la materia grasa (20\%). Aún así, el AMP en la masa cárnica al inicio del proceso se detectó a muy bajas concentraciones $(0.21 \pm 0.06 \mu \mathrm{mol} / \mathrm{g}$, b.s $)$ en ambos lotes desapareciendo casi en su totalidad al final de la etapa de maduración (24 días) (Figura 39a).
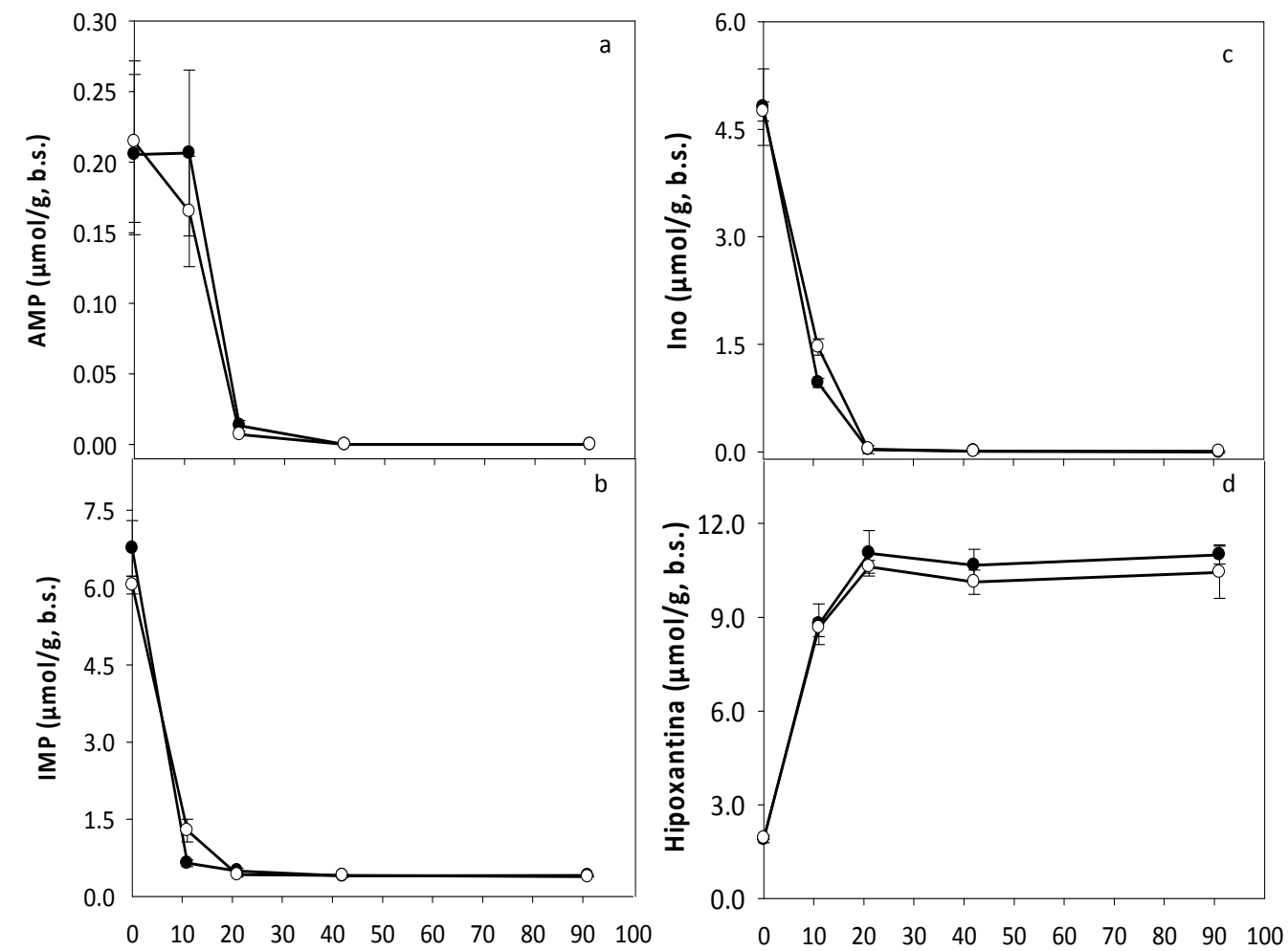

Proceso de curado (días)

Figura 39. Evolución de nucleótidos y sus derivados durante el proceso de fermentación, maduración, secado y almacenamiento envasado al vacío de embutidos fabricados con nitrito $(\circ)$ o nitrato $(\bullet)$. Las barras de error indican la desviación estándar de la media de tres embutidos. 
El IMP en la masa cárnica $(6.40 \pm 0.35 \mu \mathrm{mol} / \mathrm{g}$, b.s $)$ disminuyó rápidamente en ambos lotes de manera que al final de la etapa de fermentación (11 días) había desaparecido casi en su totalidad (Figura 39b). Estudios relacionados con la degradación del IMP en función del pH y temperatura en medios acuosos y en sistemas modelo de carne de pollo indican que la degradación del IMP se vió influido significativamente por el $\mathrm{pH}$ y el tratamiento térmico. Temperaturas altas y $\mathrm{pH}$ ácidos causan un mayor grado de degradación del IMP que a un pH neutro o alcalino (Vani et al., 2006). De este modo, las condiciones de pH (4.8) y temperatura $\left(9^{\circ} \mathrm{C}\right.$ ) en la etapa de fermentación pudieron influir en la rápida degradación del precursor principal del sabor en la carne (IMP) en mayor medida en el lote de embutidos fabricados con nitratos. Por otro lado, transformaciones rápidas de IMP a Ino en menos de 24 horas fueron observadas durante la fabricación de chorizo, presuntamente debido a la adición de sal y/o especias (Mateo et al., 1996). No obstante, el sabor de los embutidos fermentados es el resultado de la interacción de una serie de factores, como son la formulación utilizada (condimentos, aditivos, cultivos iniciadores), modificaciones fisicoquímicas y bioquímicas de la masa del embutido (acidificación, desecación, proteolisis, lipólisis), condiciones tecnológicas del proceso (H.R., temperatura, intensidad de estufajes) y envasado (al vacío o con gases) (Róncales, 1994). En este contexto, parece ser que el IMP en general tiene poca relevancia en el sabor de los embutidos al igual que los sugiere Mateo et al., (1996) en chorizo; sin embargo se han observado efectos positivos sobre el aroma en los embutidos fermentados con la adición de nitratos (Olivares et al., 2009).

Debido a la degradación del IMP se esperaría que los niveles de Ino se incrementasen con el tiempo, según lo observado en el músculo post-mortem de la sección anterior (5.2.1). Sin embargo, en los embutidos fermentados curados la Ino (4.78 $\pm 0.22 \mu \mathrm{mol} / \mathrm{g}, \mathrm{b} . \mathrm{s}$ ) al inicio del proceso tiende a desaparecer en su totalidad hasta el final de la etapa de maduración (24 días), dando lugar a la acumulación de 
Hx (Figura 39c). De este modo, los niveles más altos de $\mathrm{Hx}(10.83 \pm 0.47 \mu \mathrm{mol} / \mathrm{g}, \mathrm{b} . \mathrm{s})$ en ambos lotes, sin mostrar diferencias significativas $(p<0.05)$ entre ellos, se alcanzaron al final de la etapa de maduración (24 días), manteniéndose constantes hasta el final del proceso de curado y secado (42 días), incluso durante su almacenamiento envasados al vacío (Figura 39d).

La acumulación de $\mathrm{Hx}$ en el tiempo ha sido relacionada tanto con cambios autolíticos durante el almacenamiento como con la acción microbiana. Estudios en bacalao refrigerado sugieren que la nucleósido fosforilasa bacteriana desempeña un papel principal en la producción post-mortem de la hipoxantina (Surette et al., 1988). Sin embargo, aunque el envasado a vacío no detiene las reacciones bioquímicas ni el crecimiento de microorganismos que puedan vivir en ausencia de oxigeno (Róncales, 1994), la baja temperatura $\left(4^{\circ} \mathrm{C}\right.$ ) a la que fueron almacenados los embutidos así como la presencia de nitrito y otros factores como la desecación del producto hacen que no exista riesgo de crecimiento microbiano patógenos y se muestran como limitantes para que no se siga acumulando y/o produciendo más $\mathrm{Hx}$. De echo, algunos estudios relacionados con el envasado de pescado en atmósferas modificadas con dióxido de carbono $\left(\mathrm{CO}_{2}\right)$ y $\mathrm{N}_{2}$ (Warthesen et at., 1980; Boyle et al., 1991; Dhananjaya y Stroud 1994; Özogul et al., 2000), ponen de manifiesto que la presencia de $\mathrm{CO}_{2}$, compuesto utilizado para extender el tiempo de almacenamiento de pescado fresco en atmósferas modificadas, afecta la acumulación de $\mathrm{Hx}$. El incremento de $\mathrm{Hx}$ es más bajo en atmósferas modificadas con $\mathrm{CO}_{2}$ que en atmósferas normales. Tomando en consideración esta apreciación, es conocido que ciertas bacterias no crecen en estas atmósferas y en este caso no se produce más $\mathrm{Hx}$.

En relación con la creatinina se detectó un incremento de ésta desde el inicio del proceso $(1.05 \pm 0.04 \mu \mathrm{mol} / \mathrm{g}$, b.s) hasta el final del curado $(9.98 \pm 0.48 \mu \mathrm{mol} / \mathrm{g}$ b.s en 
promedio), para ambos lotes (nitrito y nitrato) sin mostrar diferencias significativas $(p<0.05)$ entre ellos. Incluso durante el envasado al vacío se siguió observando una tendencia a la alza y, aun cuando no se observaron diferencias significativas entre lotes $(p<0.05)$, los valores mayores fueron detectados en el lote con nitrato (12.91 \pm $0.44 \mu \mathrm{mol} / \mathrm{g}$, b.s) respecto al de nitrito (11.79 $\pm 0.95 \mu \mathrm{mol} / \mathrm{g}$ b.s $)$. Incremento en la concentración de creatinina durante el proceso de curado de jamón también ha sido recientemente observada (Mora et al., 2009). La creatina y creatinina han sido considerados precursores de aminas heterocíclicas en carnes cocinadas, sobretodo en la superficie de la carne, cuando ésta se somete a procesos que requieren altas temperaturas como el asado, frito o a la plancha).

\subsubsection{Proceso de curado de jamón.}

El jamón curado constituye uno de los productos tradicionales más importantes de la carne de cerdo en el área del Mediterráneo, además de ser altamente apreciado por los consumidores. La sal $(\mathrm{NaCl})$, un ingrediente esencial en la elaboración de este producto tiene una función importante en términos de calidad, por afectar al desarrollo del sabor, a la textura, al color, a la unión de proteínas y a la capacidad de retención de agua (Toldrá, 2002). Además actúa como conservante reduciendo la actividad de agua y/o inhibiendo la presencia de algunos microorganismos. Sin embargo, la ingesta excesiva de sal, más de $6 \mathrm{~g} / \mathrm{d}$ ía/persona, está estrechamente asociada con la hipertensión y, en consecuencia con un mayor riesgo de padecer enfermedades cardiovasculares (Ruusunen y Puolane, 2005). Algunos estudios encaminados a reducir el contenido en sal (Andrés et al., 2004), el tiempo de salado (Arnau et al, 1997) o la substitución del $\mathrm{NaCl}$ por otras sales (Blesa et al, 2008) han sido desarrollados, sin embargo, la principal dificultad surge porque estas acciones pueden alterar la bioquímica de proceso que es muy importante para el desarrollo de la textura y el sabor. 
Como anteriormente se ha mencionado, durante el proceso de curado del jamón ocurren muchos cambios bioquímicos como consecuencia de las reacciones enzimáticas que tienen lugar y esto tiene un alto impacto en la calidad del producto final (Toldrá, 2006). Entre ellas, podemos distinguir la proteólisis, la lipólisis y algunas reacciones enzimáticas del metabolismo muscular post-mortem que continúan en etapas iniciales del proceso de curado. Este es el caso de la degradación del ATP con la generación de sus productos derivados y de la glucólisis con la generación de ácido láctico como producto final (Toldrá, 2002). Por lo tanto, la actividad enzimática y la dependencia del tiempo en la degradación de los nucleótidos y sus derivados hacen interesante su estudio a lo largo del proceso de curado. Así, uno de los propósitos de este trabajo fue estudiar cómo el proceso de curado de jamón empleando tres diferentes formulaciones de sal afecta a la degradación de los nucleótidos y sus derivados. Los resultados obtenidos se describen a continuación.

\subsubsection{Evolución de los parámetros fisicoquímicos}

El jamón, durante su proceso de transformación a jamón curado experimenta diferentes ciclos de temperatura y humedad relativa (H.R.), cuyo control previene posibles alteraciones en el producto final. En este caso, a lo largo del proceso de curado se realizó el seguimiento de las pérdidas de peso, lo que permitió controlar el proceso de deshidratación del jamón, hasta alcanzar una merma del 34 \% respecto al peso inicial del jamón en fresco. Además, se determinó el porcentaje de humedad de cada una de las muestras obtenidas. De manera general, se observó un descenso significativo de la humedad en las tres formulaciones a lo largo del proceso de curado (Figura 40). Las pérdidas de humedad se hacen evidentes desde el salado hasta los 20 días de post-salado en las tres formulaciones $(p<0.001)$, debido a la acción higroscópica de la sal, que favorece la evaporación mas rápida del agua superficial. A partir de aquí, la humedad de las muestras se mantuvo constante durante el resto del post-salado con excepción de la formulación II que de los 50 a 
los 80 días disminuyó $(\mathrm{p}<0.001)$. El aumento paulatino de la temperatura y la disminución de la humedad relativa de la cámara desde el final de la etapa de postsalado, resultó en una gradual pérdida de humedad hasta llegar a estabilizarse en la etapa de maduración (7, 9 y 11 meses) en las tres formulaciones observándose diferencias significativas $(p<0.001)$ entre estas etapas.

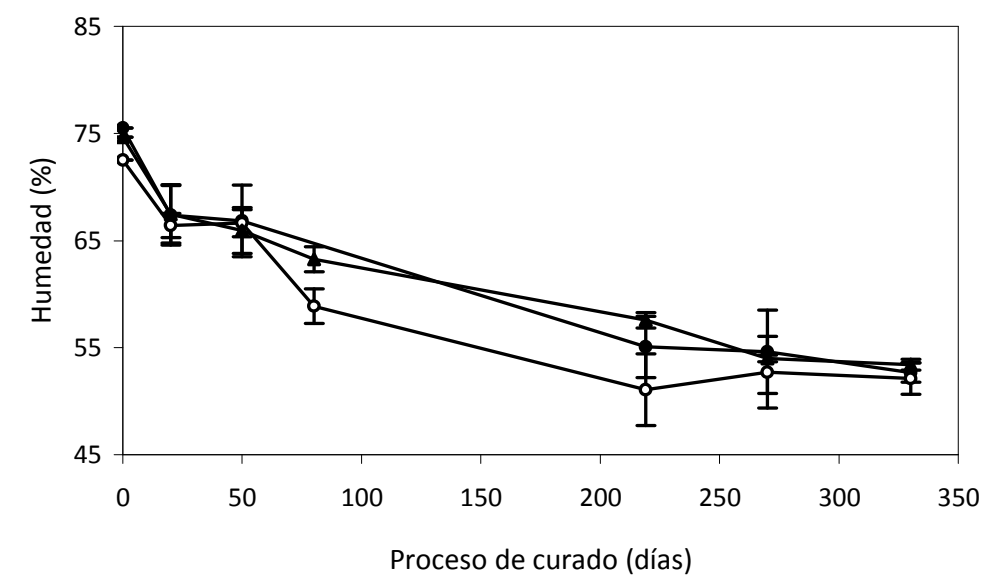

Figura 40. Evolución de la humedad en el músculo semimembranosus durante el proceso de curado de jamón con tres diversas formulaciones de la sal. $100 \%$ del $\mathrm{NaCl}, \mathrm{FI}(\bullet)$, $50 \% \mathrm{NaCl}$ y $50 \% \mathrm{KCl}$, Fll (०) y $55 \% \mathrm{NaCl}, 25 \% \mathrm{KCl}, 15 \% \mathrm{CaCl}_{2}$ y $5 \% \mathrm{MgCl}_{2}$, FIII (A). Las barras de error indican la desviación estándar de la media de tres jamones.

La evolución del pH durante el proceso de curado del jamón con las tres formulaciones de sal se muestra en la figura 41. Es conocido que el pH disminuye en el músculo post-mortem por efecto de la acumulación de acido láctico; sin embargo, se observa un ligero incremento de $\mathrm{pH}$ durante el proceso de curado. En especial en las formulaciones I y II este incremento se ve mas acusado desde la etapa de salado hasta los 50 días de post-salado respecto a la formulación III ( $p<0.001)$, para luego disminuir y estabilizarse hasta el final del proceso en las tres formulaciones. Las fluctuaciones de $\mathrm{pH}$ en los músculos de jamón situados cerca de la superficie se ven 
afectadas por varios factores, entre ellos, la rápida absorción de la sal, un secado mas rápido e intenso y finamente el crecimiento microbiano (Arnau et al., 2003).

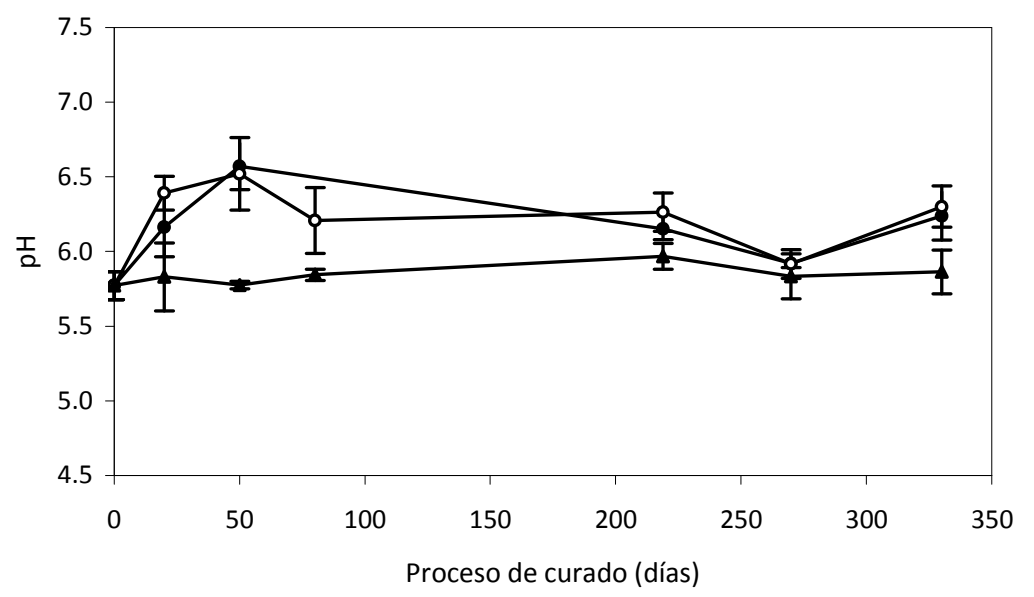

Figura 41. Evolución del pH en el músculo semimembranosus durante el proceso de curado de jamón con tres diversas formulaciones de la sal. $100 \%$ del $\mathrm{NaCl}, \mathrm{FI}(\bullet), 50 \%$ $\mathrm{NaCl}$ y $50 \% \mathrm{KCl}, \mathrm{FIl}(0)$ y $55 \% \mathrm{NaCl}, 25 \% \mathrm{KCl}, 15 \% \mathrm{CaCl}_{2}$ y $5 \% \mathrm{MgCl}_{2}$, FIII (ム). Las barras de error indican la desviación estándar de la media de tres jamones.

\subsubsection{Evolución de nucleótidos y sus derivados por RP-HPLC.}

Los nucleótidos y sus derivados se determinaron por RP-HPLC (como se describe en el apartado 4.3.2.2.) a lo largo del proceso de curado. De este modo, se detectaron y cuantificaron (en todas las formulaciones) el AMP, el IMP, Ino, Hx, X, GUA y U como se muestra en la figura 42.

El contenido de AMP en el jamón fresco $(0.79 \pm 0.08 \mu \mathrm{mol} / \mathrm{g}$, b.s $)$ disminuyó $(p<0.001)$ inicialmente en el salado y durante el secado en las tres formulaciones hasta su desaparición total después de siete meses (Figura 42a). El IMP en el jamón fresco $(8.87 \pm 0.29 \mu \mathrm{mol} / \mathrm{g}$, b.s) también disminuyó en las tres formulaciones $(p<0.001)$ de manera que al final de la etapa de post-salado (50 o 80 días) había desaparecido casi totalmente (Figura 42b). La estabilidad del IMP es superior en este 
producto que en embutidos fermentados, en los que su desaparición se da en los primeros 11 días de proceso (ver apartado 5.2.2.). La velocidad de degradación del IMP en los jamones de la formulación III ( $55 \% \mathrm{NaCl}, 25 \% \mathrm{KCl}, 15 \% \mathrm{CaCl}_{2}$ y $5 \%$ $\mathrm{MgCl}_{2}$ ) fue algo más lenta en comparación con las otras dos formulaciones, observando diferencias significativas $(p<0.001)$ a los 20 días de post-salado. Estudios previos han demostrado que la adición del cloruro de sodio (2 - 4 \%) a carne molida de ternera acelera la descomposición del ATP a IMP (Hamm, 1977), mientras que la degradación térmica del IMP y/o del GMP en una disolución acuosa se retrasó en presencia de $\mathrm{CaCl}_{2}, \mathrm{MgCl}_{2}$ y $\mathrm{MnCl}_{2}$, pero no en presencia de $\mathrm{NaCl}$ y $\mathrm{KCl}$, debido a que los iones divalentes aumentan la resistencia del enlace éster fosfato de los nucleótidos (Kuchiba et al., 1990). El agotamiento del IMP, un conocido potenciador de sabor, después de la etapa post-salado podría suponer la reducción de la intensidad del sabor de la carne; sin embargo, el efecto potenciador es sustituido por otras sustancias como la sal agregada en el proceso y/o el ácido glutámico y aspártico que se generan por proteólisis y se acumulan a lo largo del proceso de curado (Toldrá et al., 2000).

La figura $42 c$ muestra la evolución de la inosina. Las diferencias $(p<0.001)$ entre formulaciones fueron más evidentes en la etapa de post-salado. En esta etapa, la acumulación de la inosina por acción de la enzima 5'nucleotidasa sobre el IMP y la lenta conversión de Ino a Hx por la nucleosidasa fosforilasa (NP), según lo describe Tsai et al., (1972) en el músculo post-mortem, se observó únicamente en la formulación III. La hidrólisis de la inosina a Hx en esta formulación fue más lenta que en las formulaciones I y II desde el inicio del proceso de curado hasta el final de la etapa de post-salado. En las formulaciones I y II ocurrió una degradación acelerada de la inosina, encontrándose diferencias significativas $(p<0.001)$ en su contenido al inicio del salado (después de 20 días) en relación a la formulación III. Este comportamiento muestra que las reacciones enzimáticas implicadas en este proceso 
fueron afectadas probablemente por el tipo de mezcla de sal utilizada. La inosina tiende a desaparecer con el tiempo de maduración, dando lugar a una acumulación de la hipoxantina, producto derivado de su degradación, hasta 15.88 el \pm 0.77 $\mu \mathrm{mol} / \mathrm{g}$, b.s en la etapa de maduración (7, 9 y 11 meses) para las tres formulaciones (Figura 42d). Sin embargo, como en el caso de la inosina, se observaron diferencias significativas en el contenido de $\mathrm{Hx}$ en la formulación III en relación a las otras formulaciones, en la etapa de post-salado. Si bien, la acumulación de Hx resulta de la actividad de las enzimas endógenas en el músculo, algunos estudios en pescado han demostrado que bacterias responsables del deterioro, que contienen la enzima de NP pueden influir en su formación (Surette et al., 1988). Estas mismas bacterias pueden ser las responsables de la aparición de xantina por oxidación de $\mathrm{Hx}$ en algunas especies de pescados (Kassemsarn et al., 1963). En este estudio, la xantina se detectó a partir de la etapa de post-salado hasta alcanzar un valor máximo (0.32 \pm $0.11 \mu \mathrm{mol} / \mathrm{g}$, b.s) a los 7 meses y no se observaron diferencias significativas $(p<0.001)$ entre formulaciones (Figura 42e). Al final de la maduración (9 a 11 meses) se observó una disminución en el contenido de X en la formulación III.

Otros nucleósidos como la guanosina y uridina que se encuentran en la carne fresca en bajas concentraciones (Flores et al., 1999; Batlle et al., 2000) también se detectaron a lo largo del proceso de curado del jamón. La guanosina es un metabolito de la degradación del GMP (guanosina monofosfato) y contribuye a la formación de la xantina en presencia de flora microbiana (Urich, 1990). Además, la guanosina es un substrato alternativo de la NP para generar ribosa 1-fosfato y guanina, compuestos que son inhibidores de la enzima de NP (Luong y Male, 1992). El contenido de guanosina (Figura 42f) se mantuvo constante a lo largo del proceso, con un promedio de $0.30 \pm 0.02 \mu \mathrm{mol} / \mathrm{g}$, b.s Sin embargo, a los 7 y 11 meses de proceso la guanosina en la formulación III se distinguió $(p<0.001)$ de los otras formulaciones. 


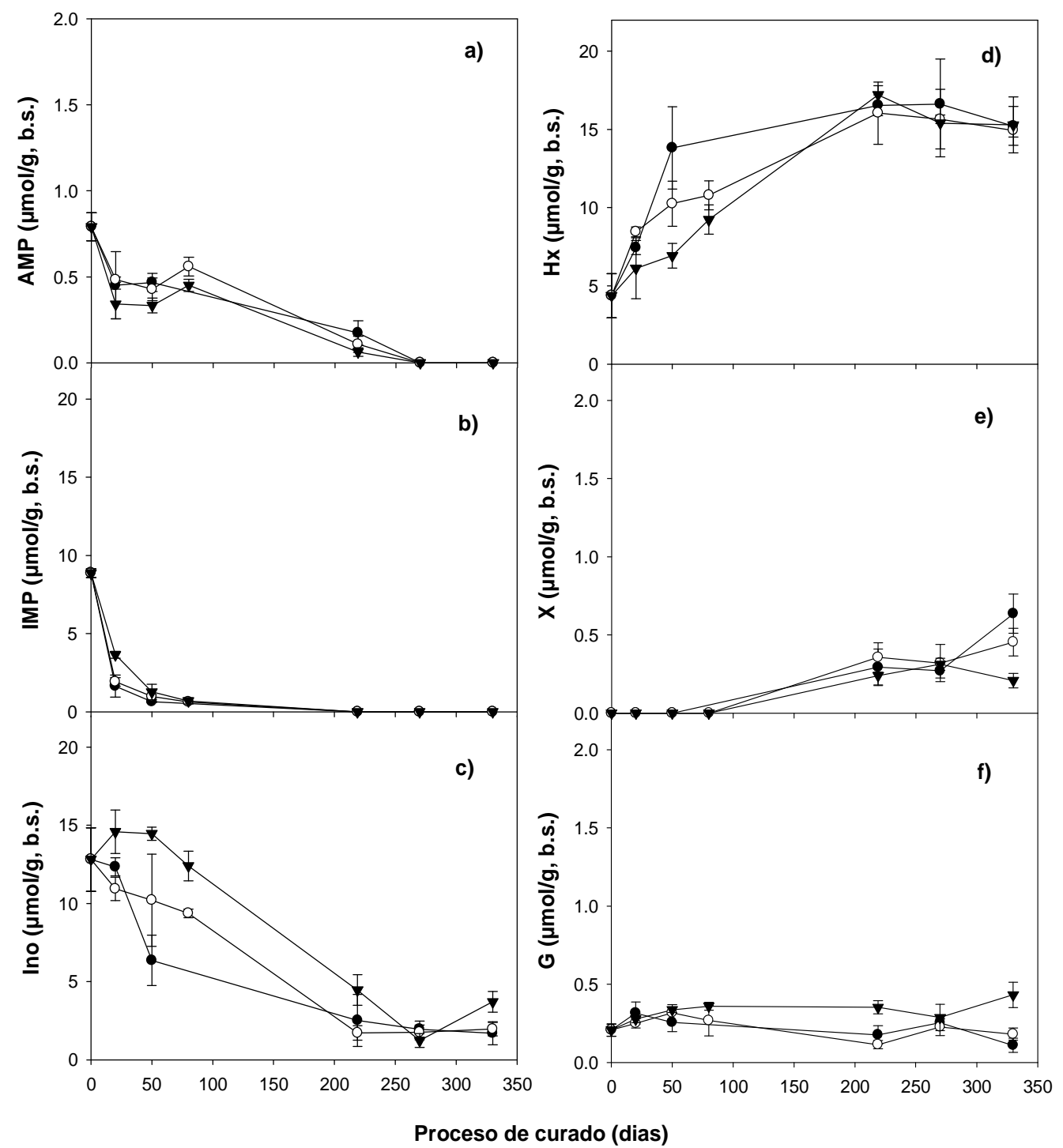

Figura 42. Evolución de nucleótidos y sus derivados en el músculo semimembranosus durante el proceso de curado de jamón usando tres diversas formulaciones de la sal. $100 \%$ del $\mathrm{NaCl}, \mathrm{FI}(\bullet), 50 \% \mathrm{NaCl}$ y $50 \% \mathrm{KCl}$, FIl (○) y $55 \% \mathrm{NaCl}, 25 \% \mathrm{KCl}, 15 \%$ $\mathrm{CaCl}_{2}$ y $5 \% \mathrm{MgCl}_{2}$, FIII ( $\boldsymbol{\nabla}$ ). a) AMP, b) IMP, c) Ino, d) Hx e) X y f) G. Las barras de error indican la desviación estándar de la medida de tres jamones. 
La temperatura y el $\mathrm{NaCl}$ generalmente se han asociado con la regulación de los procesos enzimáticos. En el jamón curado, la reducción del $\mathrm{NaCl}$ (Arnau et al., 1998; Toldrá y Flores, 1998) o el incremento de la temperatura (Arnau et al., 1997) incrementan la actividad proteolítica, lo cual puede provocar una excesiva blandura y afectar al sabor del producto final. El proceso de curado del jamón se realiza a través de sucesivos cambios de temperatura y en algunos casos, durante la maduración, se incrementa la temperatura en etapas específicas del proceso para acelerar la acción enzimática (Arnau et al., 1997). A raíz de esto es interesante conocer si la temperatura podría afectar a la concentración final de Hx. Algunos estudios sobre la degradación térmica de nucleótidos durante el enlatado de carne (Nguyen y Sporns, 1985) y otros sobre el efecto del pH y la temperatura en la degradación del IMP en un sistema modelo (Vani et al., 2006) han sido publicados con anterioridad.

La estabilidad de la Hx con el tiempo de maduración (7 a 11 meses) en las tres formulaciones se muestra en la Figura 42d. Es claro que la composición de la sal no afectó el contenido de $\mathrm{Hx}$ a este nivel de procesamiento. El efecto del tiempo de curado sobre la estabilidad de $\mathrm{Hx}$ también se analizó en jamones comerciales de 12 y 18 meses de curado que mostraron que el contenido de $\mathrm{Hx}$ no difería $(\mathrm{p}<0.001)$ entre ambos grupos ni entre aquellos observados en la experiencia de maduración de 7,9 y 11 meses descrita previamente.

La influencia del tiempo/temperatura sobre el contenido de $\mathrm{Hx}$ se estudió en el jamón curado de 11 meses de salado con la formulación I (formulación estándar) sometido a condiciones controladas de temperatura $\left(20,30,40\right.$ y $\left.70{ }^{\circ} \mathrm{C}\right)$ durante diversos tiempos $(20,40$ y $60 \mathrm{~min})$. No se observaron diferencias significativas $(p<0.001)$ en relación al control (jamón curado de 11 meses sin tratamiento térmico), confirmando que la temperatura durante el proceso de curado no tiene 
efecto sobre el contenido de $\mathrm{Hx}$, incluso a temperatura extrema $\left(70^{\circ} \mathrm{C}\right)$ aplicada durante $1 \mathrm{~h}$. Así pues, los resultados obtenidos sugieren que el contenido de la hipoxantina en jamón curado podría utilizarse como un marcador del tiempo mínimo de curado.

\subsection{Determinación de hipoxantina con el sensor enzimático y su correlación con los valores obtenidos por análisis cromatográfico.}

Como se ha visto anteriormente, la cromatografía líquida de alta resolución (HPLC) es la técnica más usada para la detección de nucleótidos y sus derivados; sin embargo, se han adaptando otros métodos analíticos, como es el uso de biosensores para la cuantificación enzimática de nucleótidos (Luong et al., 1997; Venugopal, 2002). Muchos de ellos se han centrado en la determinación de diferentes índices para el control de la frescura y maduración de distintas especies de pescado, aunque se han encontrado algunos otras aplicaciones en carne de pollo y ternera y en menor medida en carne de cerdo. La determinación conjunta o individualizada de varios nucleótidos de una muestra cárnica puede hacerse multienzimáticamente, tras la acción de sus respectivas enzimas selectivas (Karube et al., 1984; Mulchandani et al., 1990), libres y/o inmovilizadas en diversos soportes. El problema que suele plantearse cuando se determina más de un nucleótido a la vez, es poder discriminar qué proporción de la señal corresponde a cada uno de ellos, para lo que suelen emplearse cálculos matemáticos que complican demasiado el análisis cuando lo más sencillo sería aplicar un análisis cromatográfico. De esta manera, la determinación de un compuesto simple es una buena opción para utilizar los sensores enzimáticos ya que combinan la simplicidad de la operación y la selectividad del sustrato con la enzima (Yano et al., 1995 y Shizuko et al., 2005). 
Varios autores (Watanabe et al., 1983; Mulchandani et al., 1990; Luong y Male 1992; Yao T., 1993; Volpe y Mascini 1996; Batlle et al., 2001; Shizuko et al., 2005; Scheffler y Gerrard, 2007) han prestado considerable atención a la degradación de los nucleótidos en relación a la calidad y particularmente a la cuantificación de $\mathrm{Hx}$. Este compuesto ha sido propuesto como indicador de frescura o maduración, ya que el ATP, por sí solo, no se puede usar como índice de frescura porque se degrada rápidamente a otros compuestos. Es así como el contenido de $\mathrm{Hx}$ resulta muy importante ya que se va acumulando durante un almacenamiento prolongado (Tsai et al., 1972; Yao T., 1993; Özogul et al., 2000; Batlle et al., 2000 y 2001).

En este contexto, una vez se ha puesto a punto y optimizado el sensor enzimático para la enzima XO (apartado 5.1) y partiendo del conocimiento de la evolución de los nucleótidos y sus derivados en la carne y productos cárnicos (embutido fermentado y jamón curado) determinados por HPLC (apartado 5.2.), se propone el análisis y la cuantificación de la $\mathrm{Hx}$ en la carne y productos cárnicos utilizando el sensor enzimático.

\subsubsection{Maduración de la carne.}

La aplicación del sensor enzimático al análisis de muestras de carne de cerdo (Longissimus dorsi), se evaluó determinando el contenido de $\mathrm{Hx}$ a diferentes tiempos post-mortem $(5,7,9,11,27,51$ y 171 horas), tanto en un sistema con la enzima libre como inmovilizada, según el procedimiento descrito en el apartado 4.3.3. Además, el método fue validado comparando los resultados con los obtenidos en las mismas muestras por HPLC (apartado 5.2.1). En base a los resultados obtenidos de optimización del sensor enzimático (apartado 5.1), la señal amperométrica $(\mathrm{Hx}+\mathrm{X})$ obtenida al inyectar las muestras de carne en el sistema con la enzima libre, se transformó en concentración de Hx por extrapolación en la recta de calibrado obtenida a partir del consumo de oxígeno acumulado a los $190 \mathrm{~s}\left(\mathrm{mg}_{2} / \mathrm{L}\right)$ frente a 
diferentes concentraciones de $\mathrm{Hx}$, mientras que en el sistema con la enzima inmovilizada, la concentración de $\mathrm{Hx}$ se determinó a partir de la velocidad de reacción ( $\mathrm{mg} \mathrm{O}_{2} / \mathrm{L} \cdot \mathrm{s}^{-1}$ ) a los $10 \mathrm{~s}$ durante la oxidación de la $\mathrm{Hx}$ en presencia de la enzima XO. A fin de comparar esta señal, que incluye la $\mathrm{Hx}+\mathrm{X}$ formada, con los valores de Hx obtenidos por HPLC fue necesario ajustar los datos.

A partir del estudio de oxidación de la hipoxantina (apartado 5.1.1.3.), se determinó que la máxima formación de X se alcanzó justo cuando había un 33.11\% de la $\mathrm{Hx}$ inicial, y así, el 33.11 \% el consumo de oxígeno (como señal amperométrica detectada en el sistema con la enzima soluble) se debe a la $\mathrm{X}$ y por diferencia le correspondería el $66.89 \%$ a la Hx. Por otro lado, se sabe también que la actividad del $X O$ por la $X$ es la mitad de lo que es para la $H x$. Retomando la ecuación $(H x+1 / 2 X)$ propuesta por Yano et al, (1995), la señal detectada en términos de velocidad de reacción en el sistema con la enzima inmovilizada se relaciona entonces con la siguiente igualdad,

donde:

$X=33.11 \% ; H x=66.89 \% ;$ sustituyendo en la ecuación $(H x+1 / 2 X)$

entonces:

$$
\begin{aligned}
& H x+\frac{1}{2} X=66.89 \% H x+\frac{1}{2}(33.11 \%) \\
& H x=83.44 \%
\end{aligned}
$$

concluyendo que de esa señal, a la Hx le correspondería el $83.44 \%$. Por lo tanto, el contenido de $\mathrm{Hx}+\mathrm{X}$ detectado en las muestras de carne se ajustó eliminado la parte que corresponde a la $\mathrm{X}$ con su respectivo factor de ajuste para cada uno de los sistemas enzimáticos.

Los resultados ajustados $(\mathrm{Hx})$ y $\sin$ ajuste $(\mathrm{Hx}+\mathrm{X})$ en ambos sistemas enzimáticos y los obtenidos por HPLC se muestran en la figura 43. Los contenidos de $\mathrm{Hx}+\mathrm{X}$ determinados en ambos sistemas enzimáticos muestran una tendencia muy similar a 
la encontrada por HPLC $(\mathrm{Hx})$, detectando un aumento en el contenido de $\mathrm{Hx}$ con el tiempo de maduración de la carne como ya se ha visto en el análisis cromatográfico (apartado 5.2.1.).

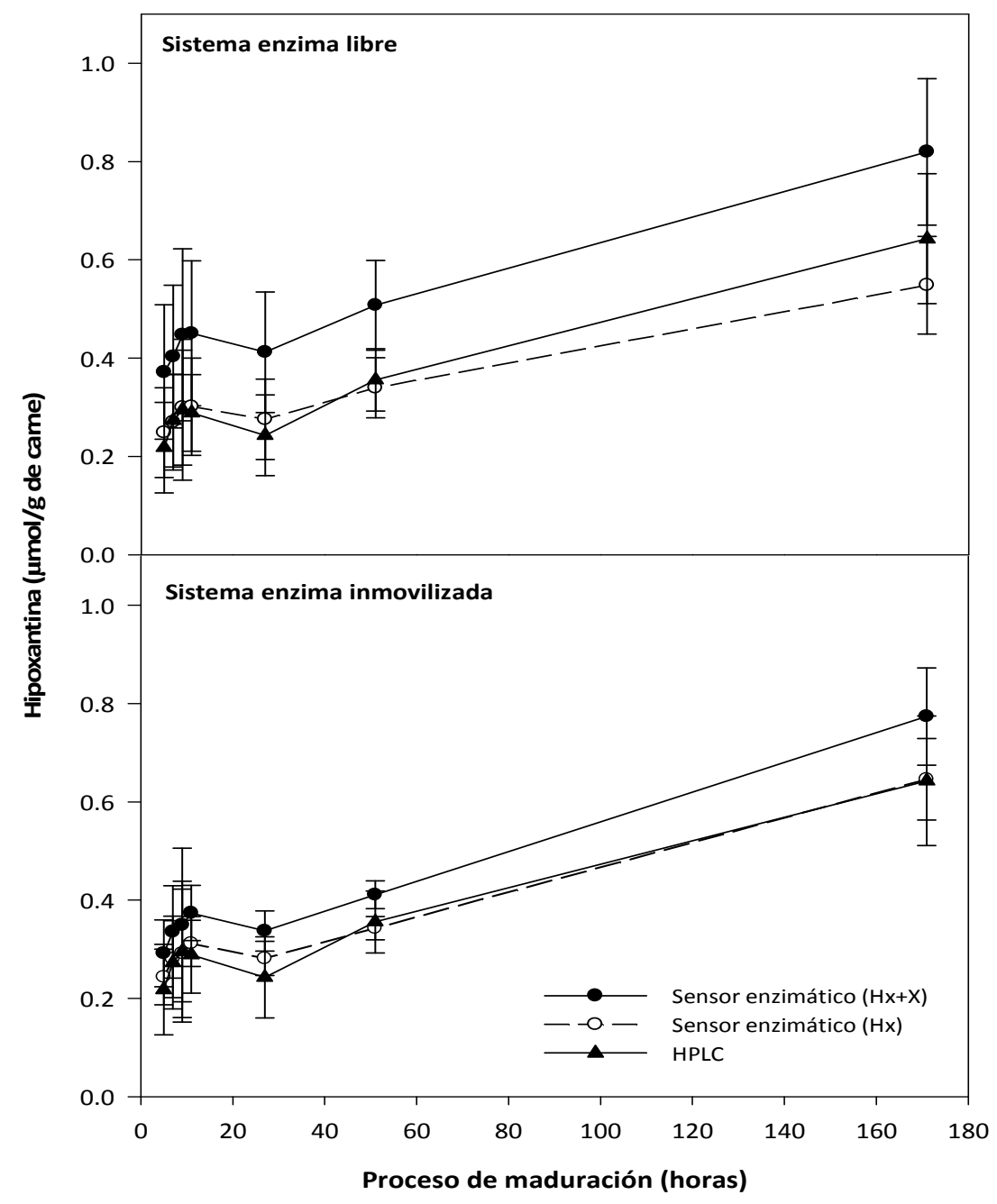

Figura 43. Evolución del contenido de hipoxantina durante el proceso de maduración en carne de cerdo (Longissimus dorsi) obtenida por HPLC y el sensor enzimático en el sistema con la enzima libre e inmovilizada. Las barras de error indican la desviación estándar de la media de cinco muestras de carne. 
Esto demuestra la sensibilidad del sensor enzimático en la detección de $\mathrm{Hx}+\mathrm{X}$ en las muestras de carne. La detección en el sistema con la enzima libre $(\mathrm{Hx}+\mathrm{X})$ fue mayor que con el sistema inmovilizado; no obstante, el contenido de Hx calculado en ambos sistemas enzimáticos después de aplicar su respectivo factor de ajuste prácticamente se superponen con los valores detectados por HPLC, sin mostrar diferencias significativas $(p<0.05)$.

La correlación entre el contenido de $\mathrm{Hx}$ calculado con ambos sensores enzimáticos, soluble e inmovilizado, y los obtenidos por HPLC en las muestras de carne se muestran en la figura 44. En ambos casos se detectó un excelente coeficiente de correlación ( $r=0.9517$ y $r=0.9620$, respectivamente). Esto sugiere que el factor de ajuste propuesto aplicado en cada sistema enzimático fue correcto para calcular el contenido de $\mathrm{Hx}$ en muestras de carne.

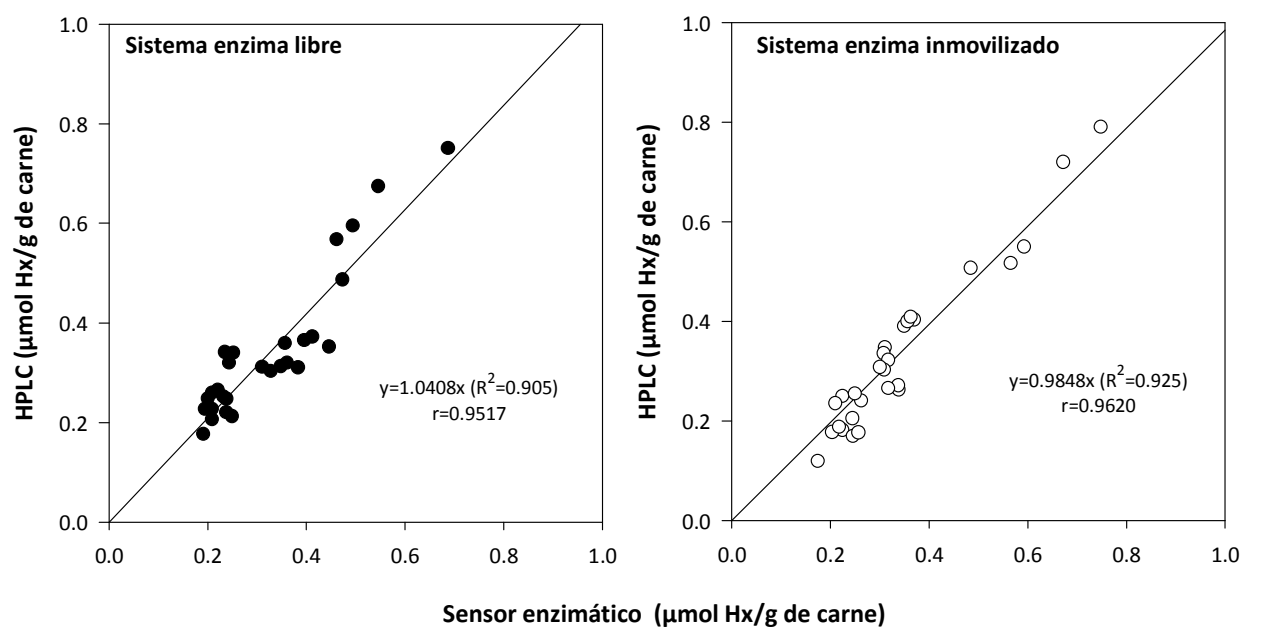

Figura 44. Correlación entre el contenido de hipoxantina obtenida por HPLC y el sensor enzimático en el sistema con la enzima libre e inmovilizada en muestras de carne de cerdo (Longissimus dorsi) a distintos tiempos post-mortem. 
Los resultados obtenidos han demostrado que el sensor enzimático propuesto, con la enzima libre o inmovilizada, constituye una excelente alternativa para la determinación de hipoxantina en muestras de carne de cerdo. Además, su fácil preparación y operación lo convierten en una herramienta fiable, rápida y económica para simples o múltiples mediciones de $\mathrm{Hx}$, en comparación con otros sensores que basan su detección principalmente en la medida del peróxido de hidrógeno. En estos sensores se requiere la utilización de potenciales positivos de operación, al que numerosos compuestos orgánicos presentes en las muestras $\left(\mathrm{H}_{2} \mathrm{O}_{2}\right.$, ácido úrico, ascorbato) son oxidables electroquímicamente y provocan interferencias en la señal. De hecho, a fin de evitar estas interferencias se hace uso de técnicas complejas para disminuir dicho potencial, como es el uso de mediadores, acoplamiento de otras enzimas (como la peroxidasa), entre otras. Por lo tanto, la utilización de un oxímetro acoplado a una enzima, mediante la detección del oxígeno consumido, es una técnica útil y más sencilla para evaluar la evolución de la maduración en la carne de cerdo como control de calidad de la frescura de la carne.

\subsubsection{Proceso de curado de un embutido fermentado.}

Los embutidos fermentados curados, deben su gran importancia a que poseen características organolépticas distintivas (sabor y textura) muy valoradas por el consumidor. La presencia del ATP y sus derivados en los productos curados durante su maduración están relacionados principalmente con el sabor, actuando como potenciadores de mismo (Mateo et al., 1996). Es el caso del IMP, conocido potenciador del sabor. EI IMP, puede también contribuir indirectamente al sabor a través de su producto de degradación, la hipoxantina, que junto con algunos aminoácidos y dipétidos dan lugar al sabor amargo (Tikk et al., 2006). De esta manera, se planteó determinar el contenido de $\mathrm{Hx}$ en función del tiempo de proceso de curado utilizando el sensor enzimático y compararlo con el ya obtenido por HPLC (apartado 5.2.2). 
Como se observó en el apartado 5.2.2., no se mostraron diferencias significativas en el contenido de $\mathrm{Hx}$ detectado por HPLC entre los lotes fabricados con nitrito y con nitrato. Tampoco se observaron efectos interferentes en el sensor a causa de la utilización de las diferentes sales de curado. Por esto, la aplicación del sensor enzimático, con la enzima libre o inmovilizada, para este tipo de productos se llevó acabo únicamente en el lote fabricado con nitrito, sin la adición de especias y en un proceso de fermentación lenta, como lote control de producción. La determinación y cuantificación de $\mathrm{Hx}$ en ambos sistemas enzimáticos se realizó de igual manera que con las muestras de carne de cerdo, utilizando los factores de ajuste propuestos para cada sistema. Las muestras fueron diluidas para adecuarse al intervalo lineal de detección de la recta de calibrado y obtener una respuesta fiable. En el sistema con la enzima libre se inyectaron $40 \mu \mathrm{L}$ de una dilución 1:6 del extracto original; mientras que en el sistema con la enzima inmovilizada la muestra se diluyó en un intervalo de 3 a 14 veces en las dos primeras etapas del proceso y 25 veces a partir de la etapa de maduración.

El análisis de la evolución de hipoxantina durante el proceso de curado en los embutidos fabricados solo con nitrito por HPLC (apartado 5.2.2.) (Figura 45) mostró un incremento rápido en el contenido de $\mathrm{Hx}$ desde el inicio del proceso hasta el final de la etapa de maduración (21 días), siendo más evidente ese incremento durante los primeros 11 días (final de la etapa de fermentación), mostrando diferencias significativas $(p<0.05)$ entre estas etapas. A partir de la etapa de maduración el contenido de $\mathrm{Hx}$ se mantuvo constante sin mostrar cambios significativos durante la etapa de secado (42 días) ni durante el almacenamiento al vació (91 días). Esta tendencia, analizada por HPLC, fue muy similar a la detectada en ambos sistemas enzimáticos lo que sugiere también la buena sensibilidad del sensor para este tipo de muestras cárnicas. Sin embargo, al igual que en la carne fresca, el sensor con la enzima libre mostró las señales más altas de detección $(\mathrm{Hx}+\mathrm{X})$; incluso, se detectaron 
diferencias significativas $(\mathrm{p}<0.05)$ con respecto al contenido de $\mathrm{Hx}$ obtenido por HPLC (Figura 45).

La respuesta de sensor enzimático en ambos sistemas, una vez realizado el ajuste correspondiente para descartar la parte proporcional de la xantina formada durante la oxidación de la $\mathrm{Hx}$, mostró estar ligeramente por debajo de la obtenida por HPLC (Figura 45), perdiéndose la relación de ajuste propuesta para la carne fresca (apartado 5.3.1.). Esta desviación puede ser debida a la complejidad de la muestra en sí. El proceso de curado de los productos cárnicos fermentados es complejo; diferentes reacciones bioquímicas se desarrollan sucesiva y paralelamente (Fadda et al, 2002), y podrían interferir en la respuesta del sensor. Durante la maduración se acumula ácido láctico debido a la fermentación de carbohidratos, la degradación proteica genera un incremento de compuestos nitrogenados no proteicos (péptidos de bajo peso molecular y aminoácidos libres), y las reacciones lipolíticas generan ácidos grasos libres que pueden generar a su vez ésteres, aldehídos y cetonas. Muchos de estos compuestos son extraídos con el método de extracción utilizado y pueden detectarse en el extracto cárnico. 


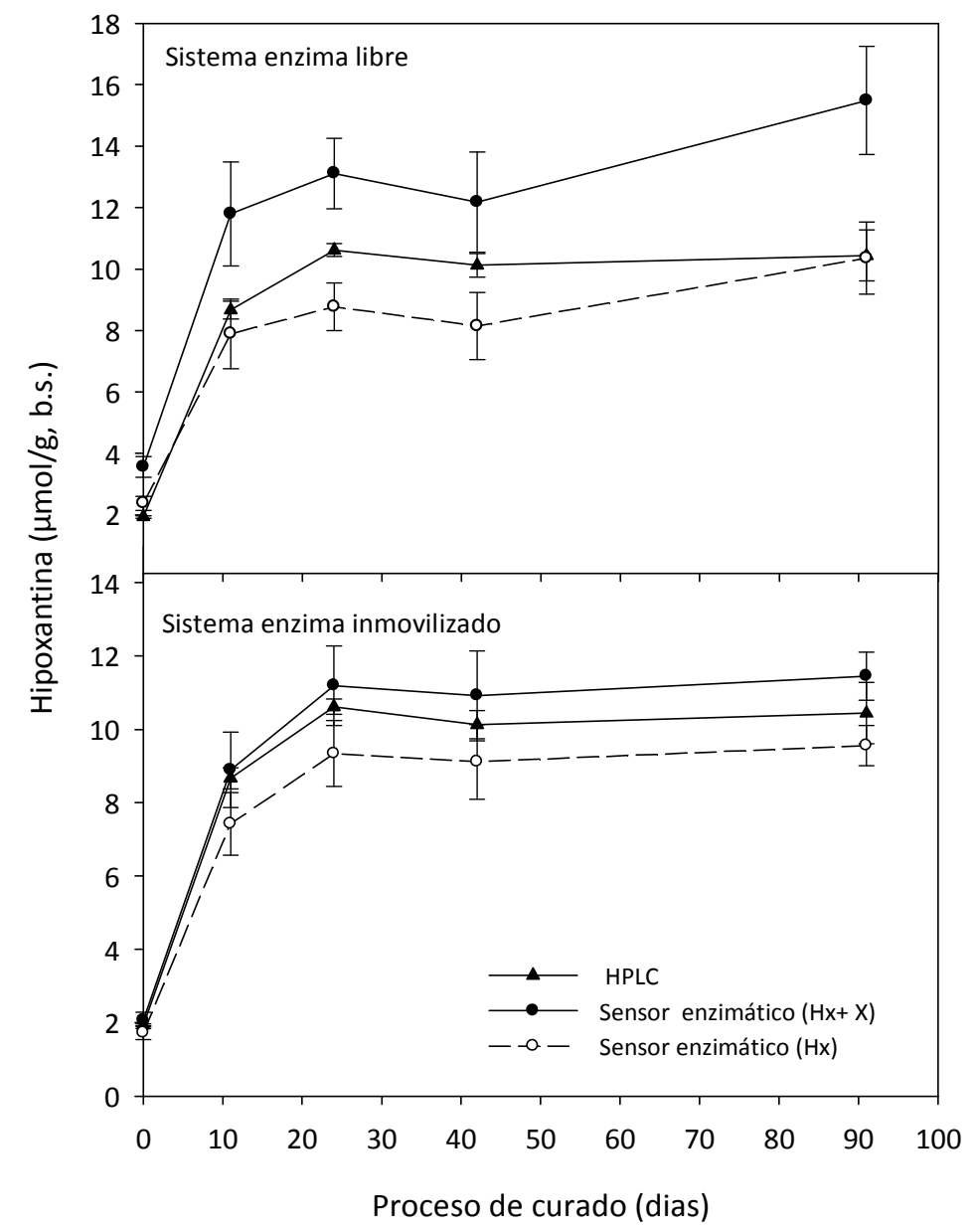

Figura 45. Evolución del contenido de hipoxantina durante el proceso de curado de un embutido fermentado obtenido por HPLC y el sensor enzimático en el sistema con la enzima libre e inmovilizada. Las barras de error indican la desviación estándar de la media de tres embutidos.

Por otro lado, la actividad proteolítica en estos productos también se ve afectada por las enzimas microbianas de las bacterias lácticas (BAL). Estas bacterias producen peróxido de hidrógeno $\left(\mathrm{H}_{2} \mathrm{O}_{2}\right)$ en presencia de oxígeno cuya acumulación también puede provocar reacciones de enranciamiento lipídico que ocasiona defectos en las características organolépticas del embutido (olores desagradables y reacciones de 
decoloración). A la par de estas reacciones, algunas especies de estafilococos a través de su actividad catalasa reaccionan con el $\mathrm{H}_{2} \mathrm{O}_{2}$ que se degrada en agua y oxígeno. Si se considera que en la reacción enzimática de oxidación de Hx se genera $\mathrm{H}_{2} \mathrm{O}_{2}$ como producto de la misma, existe la posibilidad de que la actividad enzimática de la enzima XO haya sido afectada por efecto de una inhibición por producto debida al $\mathrm{H}_{2} \mathrm{O}_{2}$ generada por las $\mathrm{BAL}$, lo que justificaría una actividad menor $y$, por tanto una sub-estimación de la cantidad de Hx, desviándose así del ajuste propuesto.

A fin de comprobar la presencia de $\mathrm{H}_{2} \mathrm{O}_{2}$ en las muestras analizadas, se realizó una exploración rápida de este compuesto por espectrofotometría, mediante una reacción enzimática indicadora (Bouvrette et al., 1997). El $\mathrm{H}_{2} \mathrm{O}_{2}$ presente en la muestra reacciona con un cromógeno (fenol/4-aminoantipirina) en presencia de la enzima peroxidasa (por la reacción de Trinder), para formar un colorante con estructura de quinonaimina que absorbe a $505 \mathrm{~nm}$. Así, la intensidad de color producido (correlacionado, por medio de su respectiva recta de calibrado, con patrón de $\mathrm{H}_{2} \mathrm{O}_{2}$ ) fue directamente proporcional a la concentración de $\mathrm{H}_{2} \mathrm{O}_{2}$ presente en las muestras. Los resultados obtenidos se muestran en la tabla 20. La mayor concentración de $\mathrm{H}_{2} \mathrm{O}_{2}$ se detectó al inicio de la etapa de maduración justo en el momento en que la determinación de $\mathrm{Hx}$ por el sensor se desvió del valor real (obtenido por HPLC), lo que confirma el posible efecto inhibidor del $\mathrm{H}_{2} \mathrm{O}_{2}$ sobre la actividad de la enzima XO.

Tabla 20. Concentración de peróxido de hidrógeno $\left(\mathrm{H}_{2} \mathrm{O}_{2}\right)$ en muestras de embutido fermentado curado, fabricados solo con nitrito sin la adición de especias y en un proceso de fermentación lenta.

\begin{tabular}{lc}
\hline Etapa de curado & $\begin{array}{c}\text { Intervalo de concentracion de } \\
\mathrm{H}_{2} \mathrm{O}_{2}(\mu \mathrm{mol} / \mathrm{L})\end{array}$ \\
\hline Inicial/Fermentación & $0.87-4.0$ \\
Maduración & $10.0-18.0$ \\
Secado/Envasado & $1.47-5.0$ \\
\hline
\end{tabular}


En vista de los resultados, que se muestran en la figura 45, el sistema con la enzima inmovilizada parece ser la mejor opción para detectar $\mathrm{Hx}$ en embutidos curados; especialmente, si se utiliza la respuesta del sensor directamente $(\mathrm{H} x+\mathrm{X}$, expresada en concentración), aunque la respuesta del sensor enzimático con ajuste tampoco mostró diferencias significativas $(\mathrm{p}<0.05)$ con los resultados de $\mathrm{Hx}$ obtenidos por HPLC y muestran una excelente correlación ( $r=0.9725$ ) (Figura 46).

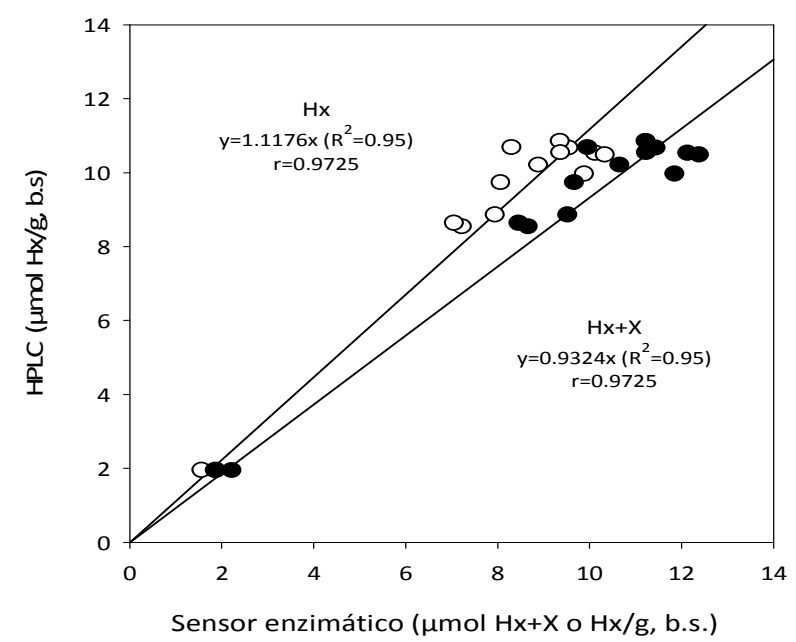

Figura 46. Correlación entre el contenido de hipoxantina obtenida por HPLC y el sensor enzimático en el sistema con la enzima inmovilizada durante el proceso de curado de un embutido fermentado. $(\bullet)$ señal directa del sensor $(H x+X)$ y $(0)$ señal ajusta da $(H x)$.

En general, los resultados sugieren que el sensor enzimático con la enzima inmovilizada puede ser un método viable para detectar el contenido de $\mathrm{Hx}$ en embutidos fermentados curados. Además, el contenido de $\mathrm{Hx}$ detectado puede usarse para evaluar el progreso de maduración durante el curado. 


\subsubsection{Proceso de curado de jamón.}

La aplicación del sensor enzimático al análisis de muestras de jamón curado se evaluó en las muestras con la formulación I (100\% NaCl) y II (50\% NaCl y $50 \% \mathrm{KCl})$ durante el proceso de curado, siguiendo el procedimiento experimental descrito en el apartado 4.3.6.

Los estudios preliminares con el sensor enzimático en la carne fresca y en el embutido curado fermentado sugirieron condiciones de trabajo y estabilidad muy buenas. Sin embargo, en este caso se decidió tan solo usar el sistema con la enzima inmovilizada para la detección de $\mathrm{Hx}$, debido a que la enzima es más estable en este sistema y puede ser reutilizada múltiples veces. En este caso, los extractos del jamón curado de ambas formulaciones (I y II) se diluyeron entre 5 y 25 veces en la etapa de post-salado y 50 veces en la etapa de maduración para se inyección en el sensor y adecuarse al intervalo lineal de detección. La velocidad de reacción detectada a los 10 s fue utilizada para cuantificar la concentración de Hx.

Los resultados de la evolución de los nucleótidos y sus derivados en el jamón curado con diversos niveles de sustitución de $\mathrm{NaCl}$ por otras sales analizado por HPLC (apartado 5.3.2.) hacen evidente la acumulación de la Hx y la presencia de xantina en las etapas finales de proceso de curado (Figura 42). La composición de la muestra del jamón curado, derivado de los procesos bioquímicos que ocurren durante el proceso de curado (proteolisis y lipólisis) (Toldrá, 2006), podría suponer interferencias en la señal de detección del sensor enzimático, como se ha visto en las muestras del embutido curado fermentado. En particular, la presencia de $\mathrm{X}$ supone una interferencia directa con la enzima $\mathrm{XO}$, debido a que ésta compite por los sitios activos de la enzima (Jezewska, 1973) con la Hx y la X formada por la oxidación de $\mathrm{Hx}$ pudiendo causar algunos problemas de selectividad (Hu et al., 2000). 
A fin de minimizar esta situación, la señal amperométrica del sensor enzimático expresada en concentración, que incluye tanto la $\mathrm{Hx}$ como la $\mathrm{X}$ formada de la oxidación de la $\mathrm{Hx}$ y la $\mathrm{X}$ propia de la muestra $(\mathrm{Hx}+\mathrm{X})$, se comparó con la suma del contenido de $\mathrm{Hx}$ y $\mathrm{X}$ obtenido por HPLC como se muestra en la figura 47.

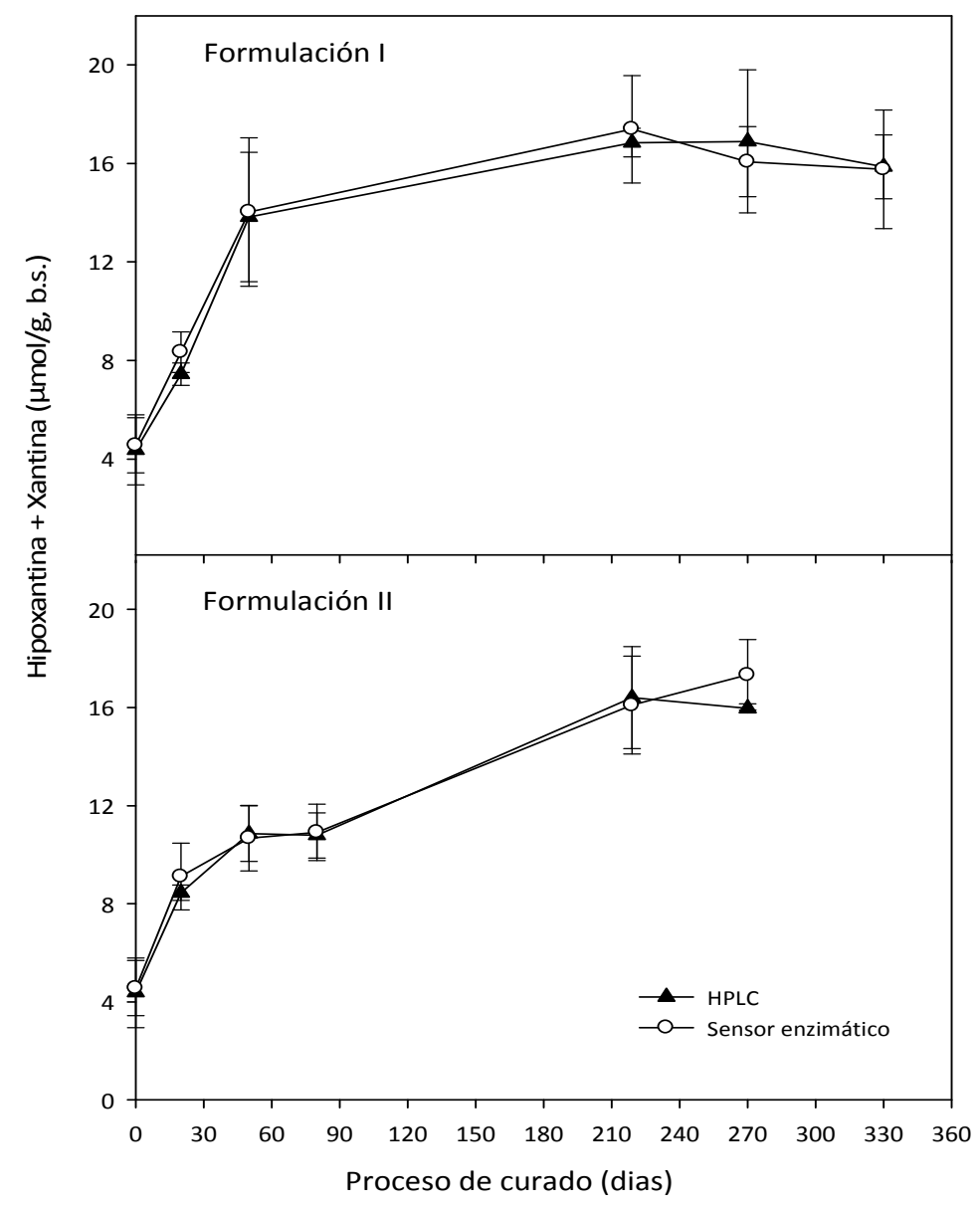

Figura 47. Evolución del contenido de hipoxantina + xantina en el jamón curado (100 \% del $\mathrm{NaCl}, \mathrm{Fl}(\bullet), 50 \% \mathrm{NaCl}$ y $50 \% \mathrm{KCl}, \mathrm{FIl}(0))$ durante el proceso de curado obtenido por HPLC y el sensor enzimático con la enzima inmovilizada. Formulación I (100 \% del $\mathrm{NaCl}$ ) y formulación II (50\% NaCl y $50 \% \mathrm{KCl})$. Las barras de error indican la desviación estándar de la media de tres jamones. 
Los resultados muestran una tendencia muy similar en las dos formulaciones ensayadas en la evolución de la hipoxantina-xantina durante el proceso de curado en ambos métodos, aunque se observó una dispersión importante en las muestras analizadas en el sensor enzimático desde la etapa de maduración, en la cual la X está presente, en comparación con las etapas iniciales donde no hay $\mathrm{X}$. Sin embargo, los resultados en general ponen de manifiesto la excelente correspondencia del sensor enzimático con el HPLC, obteniendo un coeficiente de correlación de 0.974 para ambas formulaciones (Figura 48). Por lo tanto, la determinación de Hx+X en jamón curado en el sensor enzimático constituye una alternativa válida a métodos cromatográficos debido su simplicidad y respuesta rápida. Además la detección de la $\mathrm{Hx}$ o Hx+X en el jamón curado puede ser utilizado como índice de tiempo mínimo de curado.

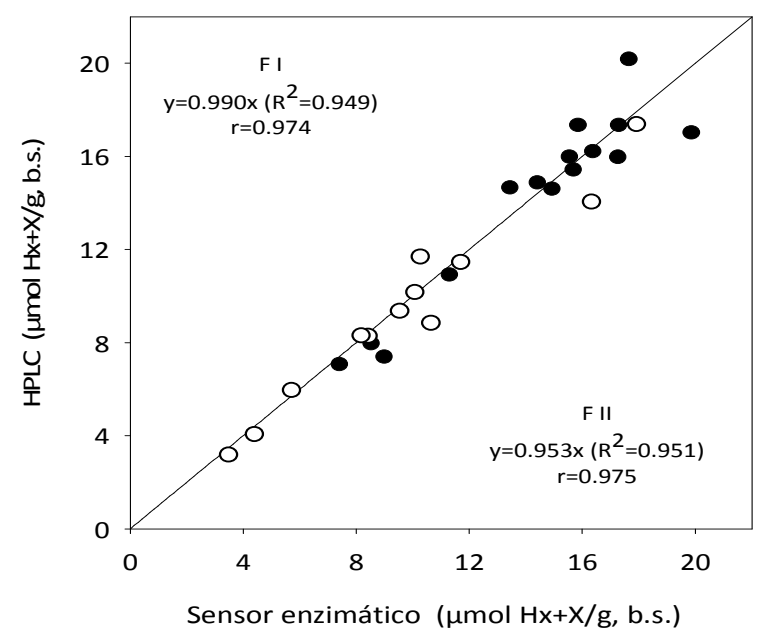

Figura 48. Correlación entre el contenido de hipoxantina + xantina durante el proceso de curado del jamón obtenida por HPLC y el sensor enzimático con la enzima inmovilizada en jamón curado. (•) $100 \% \mathrm{NaCl}$, $\mathrm{Fl}$ y (०) $50 \% \mathrm{NaCl}$ y $50 \% \mathrm{KCl}$, FII. 


\subsection{Determinación de la generación de aminas biógenas en los productos cárnicos por HPLC.}

Como anteriormente se ha descrito, la formación de las aminas biógenas en los productos cárnicos curados es debido a la descarboxilación enzimática de sus aminoácidos precursores (Figura 8), fundamentalmente por acción de enzimas descarboxilasas de origen microbiano. De esta manera, el contenido y el tipo de amina formada dependerán en gran medida de la composición del alimento, flora microbiana y de algunos otros parámetros que permitan el crecimiento bacteriano tales como tratamiento del alimento, aditivos, temperatura, humedad, maduración, envasado y almacenamiento (Halász et al., 1994). La presencia de aminas como la cadaverina (CA), putrescina (PU) e histamina ( $\mathrm{HI}$ ) en la carne y sus productos cárnicos ha sido un indicativo útil para valorar su estado higiénico o de alteración (Özogul et al., 2006), debido a que estas aminas se produce generalmente por acción de enterobacterias y pseudomonas, principales microorganismos causantes del deterioro de la carne (Hernández-Jover et al., 1996). Es así que su determinación ha sido utilizada como un parámetro para evaluar la calidad en los alimentos (Yano et al., 1996). Todo esto, unido a que el consumo en exceso de estas aminas puede causar efectos toxicológicos suponiendo un riesgo para el consumidor; incluso se han propuesto diferentes estrategias tecnológicas para la reducción de aminas biógenas (Latorre-Moratalla et al., 2010a). Aún así, en los productos cárnicos fermentados, se favorece la formación de $A B$ como consecuencia de la proteolisis (mayor disponibilidad de aminoácidos precursores) y del desarrollo de una gran variedad de microorganismos (Bover-Cid et al., 2001b), nativos o adicionados como cultivo iniciador. Mientras que en el jamón, la intensa proteolisis que se lleva a cabo durante el proceso de curado genera una gran cantidad de aminoácidos libres (Aristoy y Toldrá, 1991) que del mismo modo con el tiempo pueden transformarse en aminas biógenas. En este sentido, se planteó el análisis de AB por HPLC de un embutido fermentado con nitrito o nitrato y de un jamón empleando tres diferentes 
formulaciones de sal. Además se comparan estos resultados con los valores obtenidos mediante el sensor de enzimático descrito en el apartado 5.5.

\subsubsection{Embutidos fermentados curados.}

El crecimiento rápido de las BAL al inicio del proceso de curado de un embutido fermentado es importante para inducir la rápida acidificación y asegurar su calidad higiénica (Lücke, 1994). Sin embargo, el pH ácido estimula la síntesis y actividad aminoácido descarboxilasa, tanto de la microbiota responsable de la fermentación, como de los microorganismos contaminantes de las materias primas (Halász et al., 1994; Maijala et al., 1995). Valores bajos de pH se correlacionan con un mayor contenido de $\mathrm{AB}$ (Parente et al., 2001). Esta condición coincide con lo detectado en este estudio en el que la máxima acumulación de $A B$ totales (Figura 49) y de BAL (Figura 37) se observa entre los 20 y 40 días de curado cuando los valores de $\mathrm{pH}$ (4.7 en promedio) son los más bajos (Figura 37) en ambos lotes de fabricación. Sin embargo, la producción de $A B$ fue mayor en el lote fabricado con nitrato, tanto en el total de aminas (Figura 49) como en algunas de ellas (Figura 50). Esto confirma el efecto conservante del nitrito que actúa inhibiendo el crecimiento de microorganismos indeseables y se refleja en una menor concentración de $A B$ totales en este lote. El nitrato permite una liberación lenta de nitrito durante el proceso, cuyo efecto se ha hecho notar en la etapa de envasado al vacío en el que se aprecia una ligera disminución en el contenido de las AB. Como se observa en la figura 49, se alcanza una producción total de $22.44 \mathrm{mg} / 100 \mathrm{~g}$, b.s. al final del proceso de curado (42 días) en relación a los $48.27 \mathrm{mg} / 100$ g, b.s. en el lote con nitrato. Cabe señalar que la presencia y el incremento en el contenido de $A B$ se ve favorecido por las condiciones tecnológicas de procesamiento a altas temperaturas y humedad relativa, características típicas de una producción industrial (Latorre-Moratalla et al., 2010b). Además, entre los microorganismo capaces de formar AB están los del 
género Enterobacteriaceae que se asocian a la producción de cadaverina y/o histamina, y las BAL a la producción de tiramina (Bover-Cid et al., 2006).

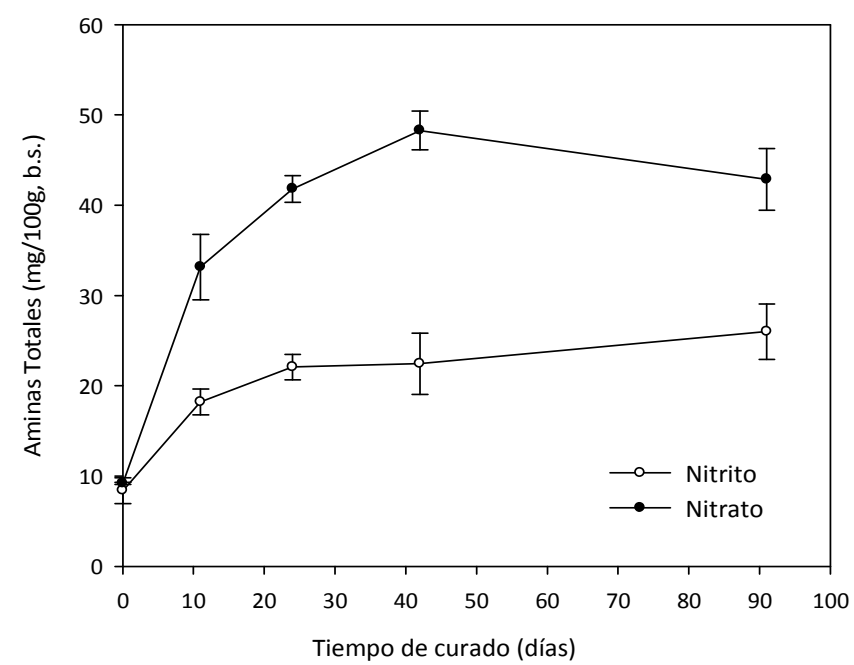

Figura 49. Evolución del contenido total de aminas biógenas durante el proceso de curado de un embutido fermentado fabricado con adición de nitrito $(\circ)$ o nitrato $(\bullet)$. Las barras de error indican la desviación estándar de la medida en tres embutidos.

Individualmente, la tiramina (TY), putrescina (PU), cadaverina (CA), histamina (HI) agmatina ( $A G)$, triptamina (TR), espermina (SM) y espermidina (SD) fueron las $A B$ detectadas, coincidiendo con lo que se ha encontrado en otros productos similares (Shalaby, 1996; Bover-Cid et al., 2006). El tiempo de curado tuvo un efecto significativo $(p<0.05)$ en la formación de la mayoría de las aminas detectadas, al aumentar paulatinamente su contenido hasta el final del proceso de curado a los 42 días. Además, el efecto de las sales de curado (nitrato o nitrito) sobre las aminas individuales fue significativo $(p<0.05)$ tan solo para la TY y CA, como se muestra en la figura 50.

La TY se detectó en ambos lotes (nitrito o nitrato) mostrando diferencias significativas entre ellos $(p<0.05)$ (figura $50 a)$, siendo la amina mayoritaria, como ha 
sido reportado en otros estudios para este tipo de productos (Eerola et al., 1997; Bover Cid et al., 2006). La máxima formación de TY se dio al final del proceso de curado (42 días) y fue de $31.30 \pm 1.27 \mathrm{mg} / 100 \mathrm{~g}$, b.s. en el lote de embutidos fabricados con nitrato y de $9.08 \pm 1.09 \mathrm{mg} / 100 \mathrm{~g}$, b.s. con nitrito. Aún cuando el lote de nitrato excede los valores reportados en otras publicaciones (Eerola et al., 1997; Bover-Cid et al., 2001a), estos están dentro de los niveles máximos tolerables (100$800 \mathrm{mg} / \mathrm{Kg}$ ) para alimentos (Shalaby, 1996). La producción de TY ha sido relacionada con la actividad tirosina descarboxilasa de las BAL (Bover-Cid et al., 2006). Sin embargo, en este estudio la producción de BAL no difiere entre lotes (Figura 37) lo que nos permite señalar que ésta sea la causa de la diferencia en la producción de la TY en embutidos con nitrito o nitrato. Al respecto, Gençcelep et al., (2007) mencionan que en productos como el sucuk (embutido seco fermentado turco), la concentración de $A B$ incrementa en ausencia de las sales de nitrito y, en particular, la concentración de tiramina disminuye a medida que se van incrementando los niveles de nitrito en la mezcla cárnica, se adicionan cultivos iniciadores o hay una combinación de ambos. Sin embargo, algunos estudios han demostrado que no siempre la utilización de cultivos iniciadores beneficia la disminución de AB. Ayhan et al., (1999) demuestran que una mezcla de cultivos iniciadores con microorganismos como L. sakei, Pediococcus pentosaceus, S. xylosus y S. carnosus evitan la formación de putrescina pero no de tiramina. De igual manera otras mezclas de microorganismos como Pediococcus pentosaceus y S. xylosus o L. sakei y S. xylosus no previenen la formación de $A B$ e incluso se pueden obtener niveles de $A B$ similares a los productos manufacturados con prácticas tradicionales sin la adición de cultivos iniciadores (Parente et al., 2001). En este caso, la interacción nitrato (disminución del nivel de nitrito al inicio del proceso) y cultivo iniciador no mostraron ningún efecto en la disminución de tiramina, coincidiendo esto con lo anteriormente mencionado. 
La CA se detectó en todas las muestra analizadas y al igual que la TY se encontraron diferencias significativas $(p<0.05)$ entre ambos lotes de fabricación (figura 50b). En el lote con nitrato, aumentó su concentración a lo largo del proceso hasta valores de $3.65 \pm 0.35 \mathrm{mg} / 100 \mathrm{~g}$, b.s. mientras que en el lote con nitrito los niveles de CA detectados son prácticamente nulos. Esto confirma el efecto bacteriostático del nitrito, ya que la CA esta ampliamente relacionada con la presencia de microorganismos responsables del deterioro (enterobacterias y pseudomonas) de la carne (Vidal-Carou et al., 1990) y de echo, altas concentraciones de CA en la materia prima indicarían una baja calidad de ésta (Bover-Cid et al., 2001b).

La PU en general esta relacionada con la actividad ornitina descaboxilasa presente en un amplio espectro de microorganismos, desde las bacterias del deterioro hasta las bacterias tecnológicas utilizadas en el proceso de fermentación (BAL y Staphylococcus) (Bover-Cid et al., 2001a). De ahí su tendencia a incrementar durante el proceso de curado como se observa en la figura 50c. No se detectan diferencias significativas entre los lotes $(p<0.05)$ y en promedio se alcanzaron concentraciones de $1.18 \pm 0.25 \mathrm{mg} / 100 \mathrm{~g}$, b.s al final del proceso de curado. Además, existe otra vía de síntesis de putrescina que implica la descaboxilación de la arginina por la arginina descarboxilasa para producir AG, precursor de la PU (Figura 8).

En este caso, la presencia de AG se hizo evidente desde los primeros días de curado hasta alcanzar un máximo al final de la etapa de fermentación de $2.45 \pm 0.30$ $\mathrm{mg} / 100 \mathrm{~g}$, b.s en el lote con nitrito y de $1.72 \pm 0.14 \mathrm{mg} / 100 \mathrm{~g}$, b.s en el lote de nitrato que posteriormente disminuyó paulatinamente hasta el final del proceso figura $50 \mathrm{~d}$. 
Las poliaminas fisiológicas, SD y SM, son las únicas aminas presentes de manera natural en la materia prima y permanecieron constantes durante todo el proceso de curado, con una concentración promedio de $0.90 \pm 0.10 \mathrm{mg} / 100$ g, b.s. y $8.42 \pm 1.03$ $\mathrm{mg} / 100 \mathrm{~g}$, b.s., respectivamente, sin observar diferencias $(p<0.05)$ entre los lotes de fabricación (Figura 50e y f).

La concertación de TR no mostró diferencias significativas entre los lotes de fabricación $(p<0.05)$ durante el proceso de curado. La tiramina se produce por descarboxilación del triptófano vía la enzima triptófano descarboxilasa y fue detectada al nivel máximo en las etapas finales del proceso a muy bajas concentraciones $(0.49 \pm 0.07 \mathrm{mg} / 100 \mathrm{~g}$, b.s.) en ambos lotes de fabricación (Figura $50 \mathrm{~g})$.

La HI fue detectada tan solo en el lote con nitrito en muy bajas concentraciones, alcanzando $0.20 \mathrm{mg} / 100 \mathrm{~g}$, b. s. al final del proceso de curado (Figura 50h). La presencia de $\mathrm{HI}$ se debe posiblemente al efecto residual de las enzimas que descarboxilan la histidina, su aminoácido precursor, durante el periodo de maduración y almacenamiento, como así lo menciona Shalaby, (1996). La ausencia de $\mathrm{HI}$ en los productos fermentados en general es atribuida a bajos $\mathrm{pH}$ y humedad relativa, condiciones desfavorables para el crecimiento de enterobacterias (Suzzi y Gardini, 2003). 


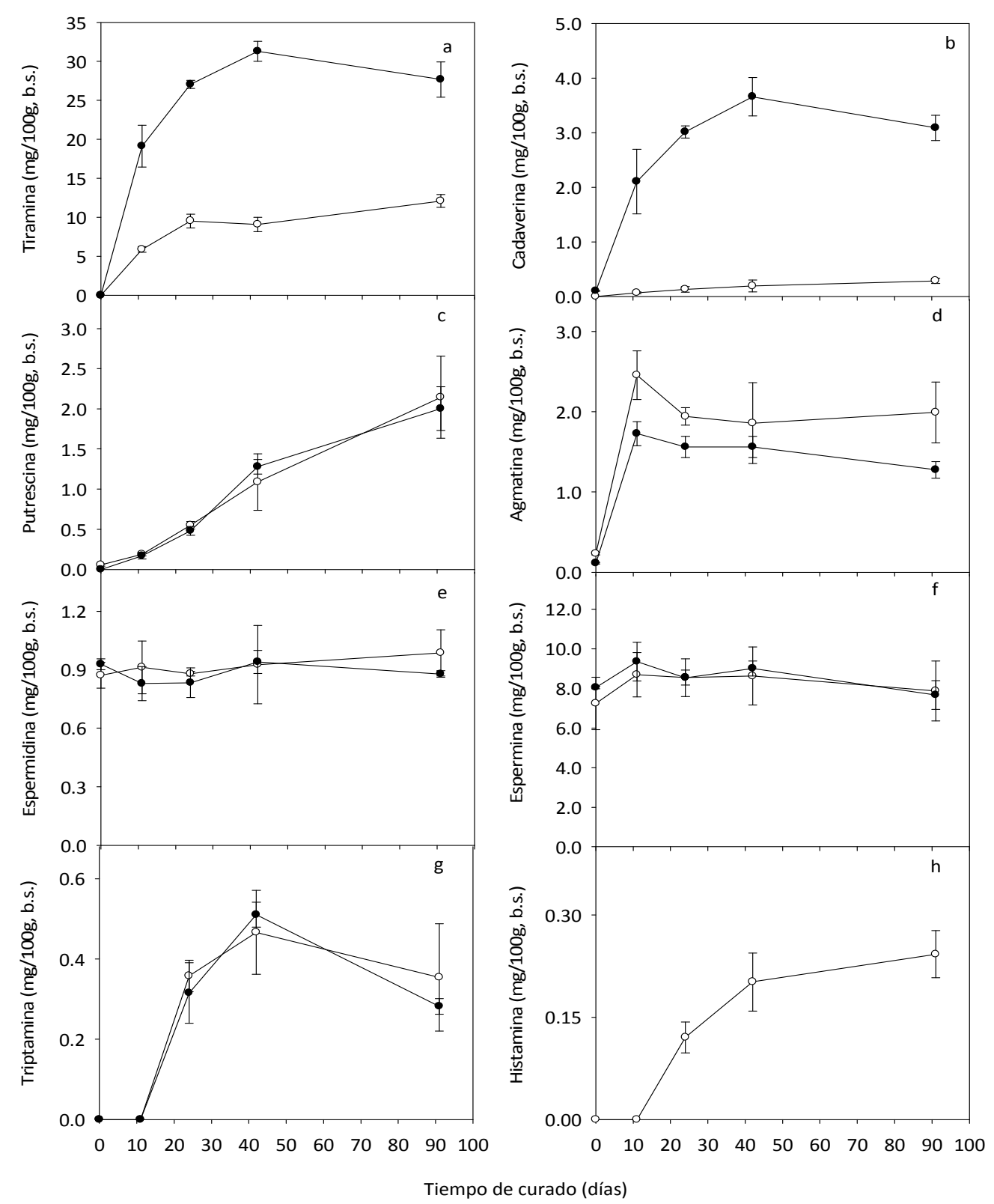

Figura 50. Evolución de aminas biógenas en el embutido fermentado durante el proceso de curado en presencia de nitrito $(\circ)$ o nitrato $(\bullet)$. Las barras de error indican la desviación estándar de la medida en tres embutidos. 


\subsubsection{Jamón curado.}

En el jamón curado, los aminoácidos libres son el producto principal de la proteolisis, resultando en un aumento de éstos durante el proceso de maduración (Aristoy y Toldrá, 1991; Córdoba et al., 1994). La intensa liberación de los aminoácidos en el jamón constituye una fuente proteica de gran importancia debido a que estos compuestos son más fácilmente asimilables por el organismo (Ventanas et al., 1992). Sin embargo, la ruta principal de formación de las aminas biógenas es la descarboxilación de esos aminoácidos y el incremento de éstos durante el procesado puede relacionarse con la actividad microbiana (Shalaby, 1996). Como se ha comentado anteriormente, las altas concentraciones de ciertas aminas biógenas en los productos cárnicos son consecuencia de la utilización de materias primas de mala calidad, pero también de la contaminación microbiana debida a condiciones inadecuadas durante el procesamiento y almacenamiento (Ruiz-Capillas y JiménezColmenero, 2004). Aún así, la formación de $A B$ en jamón curado generalmente es escasa, aunque, algunas de ellas como la putrescina, histamina, tiramina y espermina pueden detectarse en altas concentraciones en el músculo Semimembranosus, lo que podrían estar relacionado con la presencia de microorganismos en la superficie del jamón (Cordoba et al., 1994).

En la figura 51 se muestra la evolución de las $A B$ detectadas en el músculo Semimembranosus durante el proceso de curado del jamón, en las tres diferentes formulaciones de salado ( $\mathrm{Fl}, 100 \%$ del $\mathrm{NaCl}$; Fll, $50 \% \mathrm{NaCl}$ y $50 \% \mathrm{KCl}$ y $\mathrm{FIII}, 55 \%$ $\mathrm{NaCl}, 25 \% \mathrm{KCl}, 15 \% \mathrm{CaCl}_{2}$ y $5 \% \mathrm{MgCl}_{2}$ ). La determinación se llevó acabo por IP-RPHPLC y derivatización postcolumna como se describe en el apartado 4.3.5. La TY, PU, $C A, S M$ y $S D$ fueron las $A B$ detectadas en este estudio. Aunque la $H I$ y la $A G$ se detectaron en un par de jamones al final del proceso de curado, en muy bajas concentraciones. 
El tiempo de curado tuvo un efecto leve en la formación de la mayoría de las aminas en las tres formulaciones, aumentando su contenido a partir de los 7 meses de curado, con excepción de la espermidina que tiende a disminuir (Figura 51). Además, el efecto de las diferentes formulaciones de sal sobre las aminas individuales al final del proceso de curado (7-11 meses) se observa tan solo en la TY, PU, CA, siendo más evidente en las muestras fabricadas con la formulación III y en menor medida en la formulación II. Al respecto, Arnau et al., (1998) mencionan que la sal, ingrediente multifuncional en la elaboración del jamón curado, afecta la calidad y la seguridad. Así, una reducción de $\mathrm{NaCl}$ permite una mayor actividad proteolítica, que da como resultado una mayor generación de aminoácidos libres disponible para su descarboxilación y posible formación a aminas. La sustitución parcial del $50 \% \mathrm{NaCl}$ por $\mathrm{KCl}$ en lomos curados no tiene un efecto significativo en los fenómenos de proteolisis y lipólisis (Armenteros et al., 2009), lo que sugiere que la formulación II se asemeje algo mas en cuanto a la producción de aminas a las muestras de jamón curado de la formulación I (100 \% NaCl).

El contenido de $\mathrm{TI}, \mathrm{PU}, \mathrm{CA}$ en las primeras etapas de proceso (hasta 80 días), no mostró diferencias significativas $(p<0.05)$ entre formulaciones, obteniendo niveles máximos de $1.14 \pm 0.30,1.61 \pm 0.2 .04$ y $0.43 \pm 0.25 \mathrm{mg} / 100 \mathrm{~g}$, b.s, respectivamente, $\mathrm{y}$ coincidiendo estos valores con los detectados en otras investigaciones (Córdoba et al., 1994). En las etapas posteriores de maduración (7-11 meses), se observó un incremento en el contenido de estas aminas, excepto en la formulación I, que mantuvo una concentración estable hasta el final del proceso de curado. La formulación III exhibió las más altas concentraciones de TY (31.39944 \pm 7.66 $\mathrm{mg} / 100 \mathrm{~g}$, b.s), PU (12.43 $\pm 15.027004 \mathrm{mg} / 100 \mathrm{~g})$ y CA (105 $\pm 0.204 \mathrm{mg} / 100 \mathrm{~g} 105.61 \pm$ $115.611 \mathrm{mg} / 100 \mathrm{~g}$, b.s., confirmando con esto la importancia de la sal en los productos curados. 
La SM y SD fueron detectadas en todos los jamones analizados, no se observaron diferencias significativas $(p<0.05)$ entre formulaciones de sal (Figura 51), y siguieron el comportamiento que Hernández-Jover, (1997) describe como típico de estas aminas.
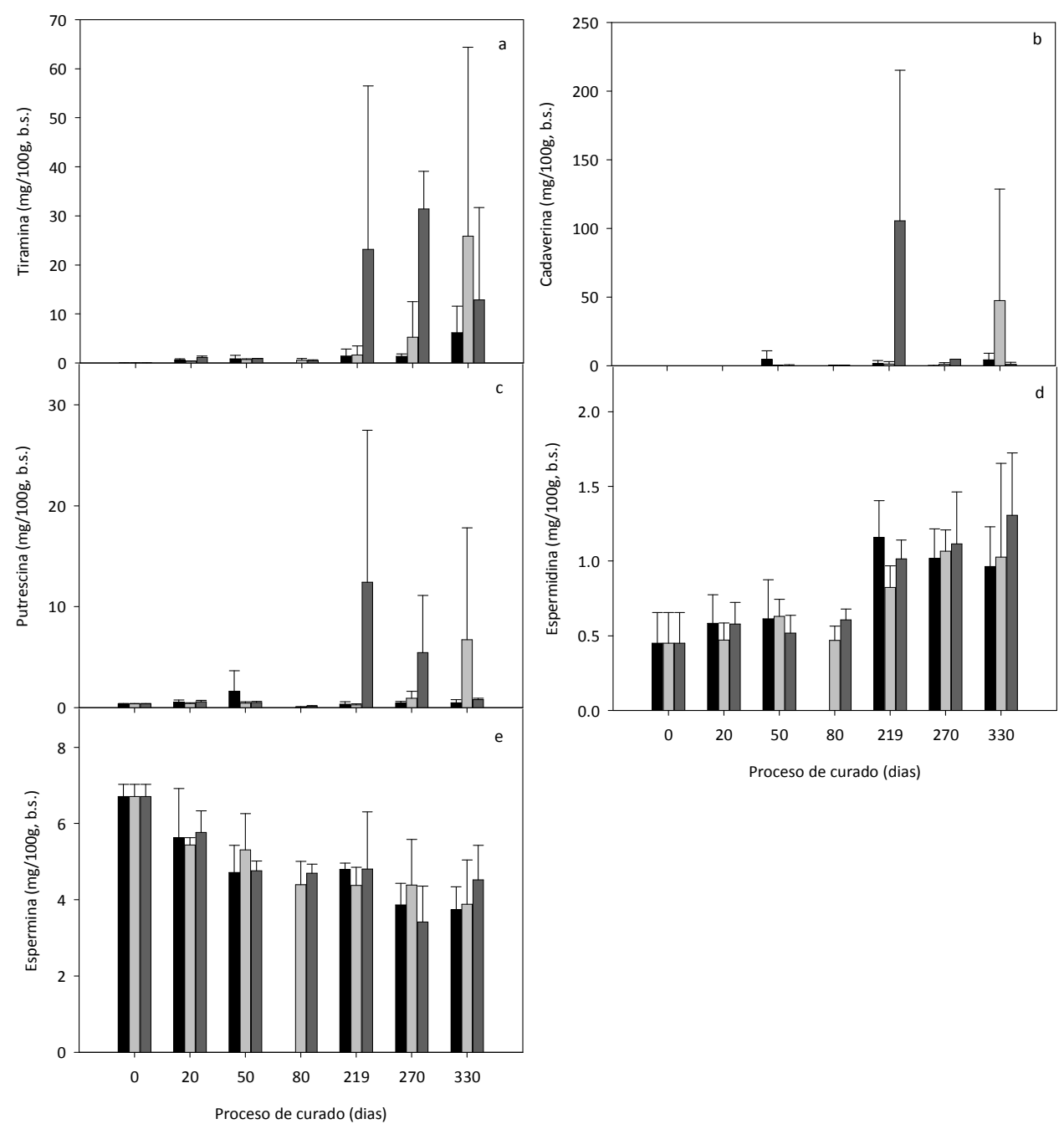

Figura 51. Evolución de aminas biógenas en el músculo Semimembranosus durante el proceso de curado de jamón con tres formulaciones de sal. $100 \%$ del $\mathrm{NaCl}, \mathrm{FI}(\mathbf{\square})$, $50 \% \mathrm{NaCl}$ y $50 \% \mathrm{KCl}$, FII (-) y $55 \% \mathrm{NaCl}, 25 \% \mathrm{KCl}, 15 \% \mathrm{CaCl}_{2}$ y $5 \% \mathrm{MgCl}_{2}$, $\mathrm{FIII}$ (-). 


\subsection{Determinación de aminas biógenas en los productos cárnicos analizados con el sensor enzimático y su correlación con HPLC.}

\subsubsection{Proceso de curado de un embutido fermentado.}

Como anteriormente se ha mencionado, varios factores tales como; la selectividad de DAO, el pH, la combinación de diversas aminas, la composición de la matriz cárnica en las diversas etapas del proceso de curado, impidieron la construcción de una curva de calibrado para cuantificar el contenido de aminas totales. Sin embargo, el sensor enzimático pudo detectar los diferentes niveles de $A B$ totales en las muestra analizadas. El intervalo de detección del sensor DAO en muestras reales fue de 0.01 a $0.07 \mathrm{mg} / \mathrm{mL}$ (Figura 52).

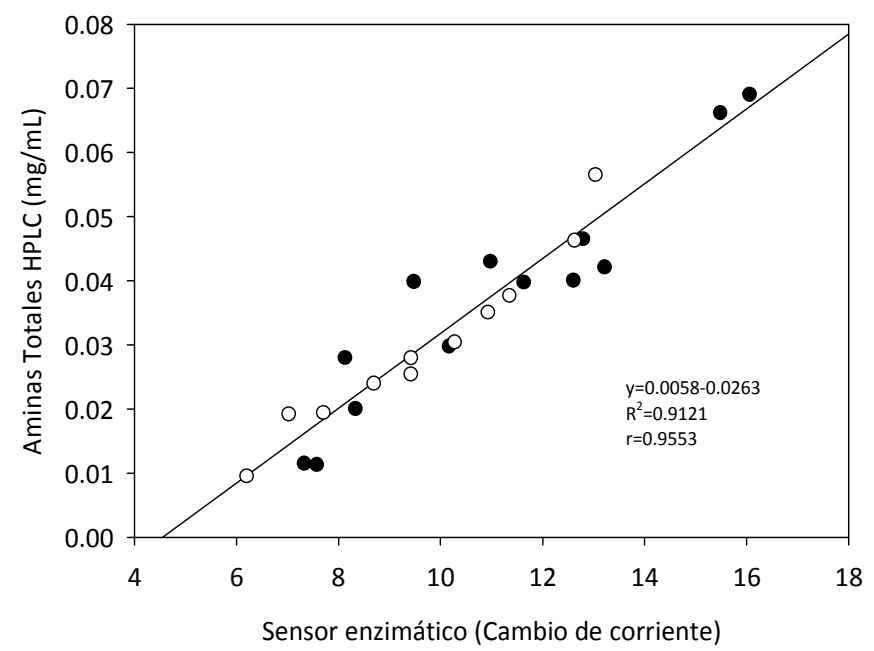

Figura 52. Correlación entre el contenido de aminas biógenas obtenida por HPLC y el sensor enzimático DAO durante el proceso de curado de un embutido fermentado con nitrito $(\circ)$ o nitrato $(\bullet)$. Cada punto corresponde a la media de tres inyecciones.

A concentraciones mayores o menores de ese intervalo se obtuvieron señales anómalas de respuesta tal como se mostró en la figura 28, por lo que al final del proceso las muestras tuvieron que ser diluidas para adecuarse al intervalo lineal de 
concentración. Los resultados en general ponen de manifiesto la excelente correspondencia del sensor enzimático con los datos de $A B$ totales obtenidas por HPLC con un coeficiente de correlación de 0.9553 (Figura 52). Estos resultados sugieren que el sensor enzimático con la enzima DAO comercial inmovilizada puede ser un método viable para realizar una exploración rápida o "screening" del contenido de aminas biógenas totales en embutidos fermentados curados.

\subsubsection{Jamón curado.}

El análisis de las $A B$ totales del jamón curado con las diferentes formulaciones de sal durante el proceso de curado, utilizando el sensor enzimático DAO se evaluó siguiendo el procedimiento experimental descrito en el apartado 4.3.3. Los niveles de $A B$ detectados por HPLC (apartado 5.4.2.), al inicio del proceso de curado presentaron una concentración $<0.01 \mathrm{mg} / \mathrm{mL}$, motivo por el cual no pudieron ser detectadas en el sensor enzimático. La correlación entre los métodos se realizó con los extractos cárnicos del final del proceso de curado (11 meses), obteniendo un coeficiente de correlación de 0.9330 (Figura 53). El sensor DAO con estas muestras fue sensible en un intervalo de 0.01 a $0.06 \mathrm{mg} / \mathrm{mL}$. Como puede observarse el jamón curado mostró una respuesta menor que los embutidos fermentados, debido quizá a un efecto matriz menos intenso a ese tiempo de curado. Una vez mas, los resultados sugieren que el sensor enzimático aplicado a las muestras de jamón curado al igual que en el caso de los embutidos fermentados permite realizar tan solo una exploración rápida del contenido de aminas biógenas con buenos resultados, siendo una herramienta útil para el control de la calidad y seguridad de estos productos. 


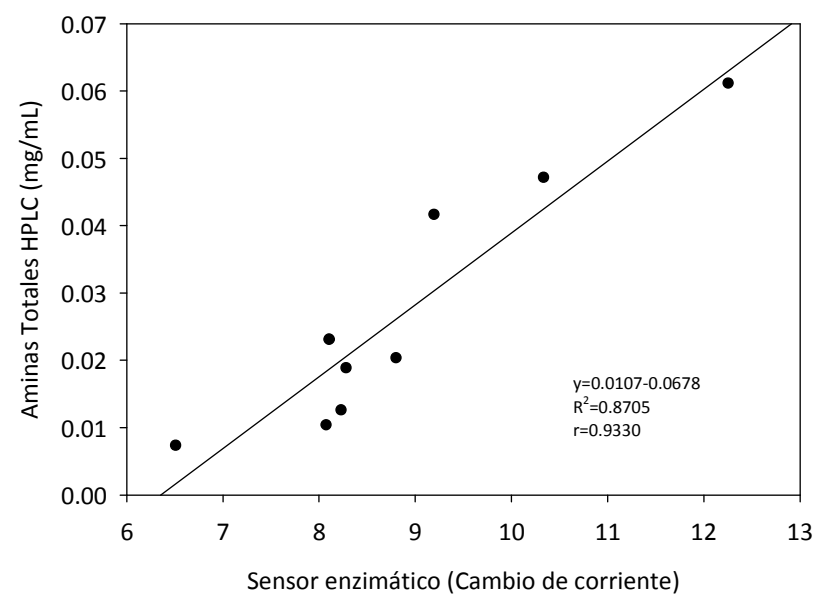

Figura 53. Correlación entre el contenido de aminas biógenas totales en jamones curados de 11 meses obtenida por HPLC y el sensor enzimático DAO. Cada punto representa la media de tres inyecciones. 
6. Conclusiones 



\section{Conclusiones}

- La cromatografía líquida de interacción hidrofílica (HILIC) en HPLC constituye un método válido, fiable y alternativo al IP-RP-HPLC para evaluar la frescura de la carne mediante el análisis de los nucleótidos y sus derivados.

- La evolución de los nucleótidos para el estudio de la calidad en los embutidos fermentados curados no se vio afectada por el uso de nitrito o nitrato. Sin embargo, se observó mayor presencia de tiramina y cadaverina en el lote tratado exclusivamente con nitrato.

- En los jamones curados que habían sido salados con la sustitución parcial de $\mathrm{NaCl}$ por sales divalentes, se detectó una mayor concentración de aminas biógenas. La velocidad de degradación de los nucleótidos en estos jamones fue menor al inicio del proceso, aunque la acumulación de $\mathrm{Hx}$ y $\mathrm{X}$ a los 7 meses alcanzó los mismos contenidos independientemente de la composición de la mezcla de sales.

- El sensor enzimático basado en la enzima xantina oxidasa resultó ser un método, viable, rápido y económico para la determinación de hipoxantina tanto para evaluación de la frescura de la carne de cerdo como para la evaluación de la maduración en las primeras etapas del proceso de curado de embutidos y/o ser usado como indicador del tiempo mínimo de curado en jamón.

- El sensor enzimático basado en la enzima comercial diamino oxidasa para la detección de aminas biógenas fue selectiva a HI, PU y CA. El sensor desarrollado resultó ser una herramienta valida de exploración o "screening" para detectar la presencia de dichas aminas en productos cárnicos y los valores obtenidos se correlacionan bien con los obtenidos por técnicas cromatográficas. 

7. Bibliografía 



\section{Bibliografía}

Agüi, L., Manso, J., Yáñez-Sedeño, P. \& Pingarrón, J. M. 2006. Amperometric biosensor for hypoxanthine based on immobilized xanthine oxidase on nanocrystal gold-cabon paste electrodes. Sensors and Actuators B. 113, 272280.

Alpert, A. J. 1990. Hydrophilic-interaction chromatography for the separation of peptides, nucleic-acids and other polar compounds. Journal of Chromatography. 499, 177-196.

Andújar, G., Pérez D. \& Venegas, O. 2009. Los cambios post mortem y la transformación del músculo en carne. En: Química y bioquímica de la carne y los productos cárnicos. 125 p. Instituto de Investigaciones para la industria alimentaria. Editorial Universitaria. La Habana, Cuba.

Andrés, A. I., Cava, R., Ventanas, J., Muriel, E. \& Ruiz, J. 2004. Lipid oxidative changes throughout the ripening of dry-cured Iberian hams with different salt contents and processing conditions. Food Chemistry. 84, 375-381.

Aristoy, M. C. \& Toldrá, F. 1991. Desproteinization techniques for HPLC amino acid analysis in fresh pork muscle and dry-cured ham. Journal of Agriculture Food Chemistry. 39, 1792-1795.

Aristoy, M. C. \& Toldrá, F. 1995. Isolation of flavor peptides from raw pork meat and dry-cured ham. In Food flavors: Generation, analysis and process influence. Ed. G. Charalambous. pp 1323-1344. Elsevier Science. Amsterdam, The Netherlands.

Aristoy, M. C. \& Toldrá, F. 2009. Nucleotides and its derived compounds. In: Handbook of Muscle Foods Analysis. Eds. M. L. Nollet and F. Toldrá. pp 279288. CRC Press, Boca Ratón, FL, USA.

Aristoy, M. C., Mora, L., Hernández-Cázares, A. S. \& Toldrá, F. 2010. Nucleotides and nucleosides. In: Handbook of Seafood and Seafood Products Analysis. Eds. M. L. Nollet and F. Toldrá. pp 57-67. CRC Press, Boca Ratón, FL, USA. 
Arnau, J., Gou, P. \& Guerrero, L. 1994. The effects of freezing, meat pH and storage temperature on the formation of white film and tyrosine crystals in drycured hams. Journal of the Science of Food and Agriculture. 66, 279-282.

Arnau, J., Guerrero, L., Casademont, G. \& Gou, P. 1995. Physical and chemical changes in different zones of normal and PSE dry-cured ham during processing. Food Chemistry. 52, 63-69.

Arnau, J., Guerrero, L. \& Gou, P. 1997. Effects of temperature during the last month of ageing and of salting time on dry-cured ham aged for six months. Journal of the Science of Food and Agriculture. 74, 193-198.

Arnau, J. 1998. Principales problemas tecnológicos en la elaboración de jamón curado. El jamón curado: Tecnología y análisis de consumo. Simposio Especial-44th International Congress of Meat Science and Technology ICoMST. Eds. J. Arnau y J. M. Monfort. pp 71-86. Editado por I.R.T.A. y Eurocarne. España.

Arnau, J., Guerrero, L. \& Sárraga, C. 1998. The effect of green ham $\mathrm{pH}$ and $\mathrm{NaCl}$ concentration on cathepsin activities and the sensory characteristics of drycured hams. Journal of the Science of Food and Agriculture. 77, 387-39.

Arnau, J., Gou, P. \& Comaposada, J. 2003. Effect of the relative humity of drying air during the resting period on the composition and aspects of dry-cured ham surface. Meat Science. 65, 1275-1280.

Armenteros, M., Aristoy, M. C., Barat, J. M. \& Toldrá, F. 2009. Biochemical changes in dry-cured loins salted with partial replacements of $\mathrm{NaCl}$ by $\mathrm{KCl}$. Food Chemistry. 117, 627-633.

Ayhan, K., Kolsarici, N. \& Özkan, G. A. 1999. The effects of a starter culture on the formation of biogenic amines in Turkish soudjoucks. Meat Science. 53, 183188.

Barat,J. M., Gil, L., García-Breijo, E., Aristoy, M. C., Toldrá, F., Martínez-Máñez, R. \& Soto, J. 2008. Freshness monitoring of sea bream (Sparus aurata) with a potentiometric sensor. Food Chemistry. 108, 681-688. 
Batlle, N., Aristoy, M. C. \& Toldrá, F. 2000. Early postmortem detection of exudative pork meat based on nucleotide content. Journal of Food Science. 65, 413416.

Batlle, N., Aristoy, M. C. \& Toldrá, F. 2001. ATP metabolites during aging of exudative and nonexudative pork meats. Journal of Food Science. 66, 68-71.

Blesa, E., Aliño, A., Barat, J. M., Grau, R., Toldrá, F. \& Pagán, M. J. 2008. Microbiology and physico-chemical changes of dry-cured ham during the post-salting stage as affected by partial replacement of $\mathrm{NaCl}$ by other salts. Meat Science. 78, 135-142.

Bolumar, T., Nieto, P. \& Flores, J. 2001. Acidity, proteolysis and lipolysis changes in rapid cured fermented sausage dried at different temperatures. Food Science and Technology. 7, 269-276.

Bouvrette, P., Male, K. B. Luong, H. J \& Gibbs, B. F. 1997. Amperometric biosensor for diamine using diamine oxidase purified from porcine kidney. Enzyme and Microbial Technology. 20, 32-38.

Bover-Cid, S., Schoppen, S., Izquierdo-Pulido, M. \& Vidal-Carou, M. C. 1999. Relationship between biogenic amine contents and the size of dry fermented sausages. Meat Science. 51, 305-311.

Bover-Cid, S., Hugas, M., Izquierdo-Pulido, M. \& Vidal-Carou, M. C. 2001a. Amino acid- decarboxylase activity of bacteria isolated from fermented pork sausages. International Journal of Food Microbiology, 66, 185-189.

Bover-Cid, S., Izquierdo-Pulido, M. \& Vidal-Carou, M. C. 2001b. Effectiveness of Lactobacillus sakei starter culture in the reduction of biogenic amine accumulation as a function of the raw material quality. Journal of Food Protection. 64, 367-373.

Bover-Cid, S., Miguelez-Arrizado, M. J., Latorre-Moratalla, L. L. \& Carou-Vidal, M. C. 2006. Freezing of meat raw materials affects tyramine and diamine accumulation in spontaneously fermented sausages. Meat Science. 72, 6268. 
Boyle, D. L., Lindsay, R. C. \& Stuiber, D. A. 1991. Adenine nucleotide degradation in modified atmosphere chill-stored fish. Journal Food Science. 56, 1267-1270.

Bravo-Sierra, P. A., Ruiz-Cabrera, M. A., González-García R. \& Grajales-Lagunes, A. 2005. Influencia de la temperatura de refrigeración (pre-rigor) sobre la incidencia de la carne PSE en cerdo. Revista Mexicana de Ingeniería Química. 4, 181-189.

Burns, B. G. \& Ke, P. J. 1985. Liquid-chromatographic determination of hypoxanthine content in fish tissue. Journal of the Association of Official Analytical Chemists. 68, 444-448.

Burns, G. B., Ke, P. J., \& Irvine, B. B. 1985. Objective procedure for fish freshness evaluation based on nucleotide changes using a HPLC system. Canadian technical report of fisheries and aquatic science. No. 1373.

Carelli, D., Centonze, D., Palermo, C., Quinto M. \& Rotunno, T. 2007. An interference free amperometric biosensor for the detection of biogenic amines in food products. Biosensors and Bioelectronics. 23, 640-647.

Cambero, M. I., Pereira-Lima, C. I., Ordoñez, J. A. \& de Fernando, G. D. G. 2000. Beef broth flavour: Relation of components with the flavour developed at different cooking temperatures. Journal of the Science of Food and Agriculture. 80, 1519-1528.

Carsol, M. A. \& Mascini, M. 1998. Development of a system with enzyme reactor for the determination of fish freshness. Talanta. 47, 335-342.

Carsol, M. A. \& Mascini, M. 1999. Diamine oxidase and putrescine oxidase immobilized reactors in flow injection analysis: a comparation in substrate specificity. Talanta. 50, 141-148.

Castro-Giráldez, M., Botella, P., Toldrá, F. \& Fito, P. 2010. Low-frequency dielectric spectrum to determine pork meat quality. Innovative Food Science and Emerging Technologies. 11, 376-386.

Cayuela, G., Peña, N., Reviejo, A. J. \& Pingarrón, M. J. 1998. Development of a bioenzymatic graphite-Teflon composite electrode for the determination of hypoxanthine in fish. Analyst. 1232: 371-377. 
Chaubey, A. \& Malhotra, B. D. 2002. Mediated biosensor. Biosensors and Bioelectronic. 17, 441-456.

Chemnitius, G. C., Suzuki, M., Isobe, K., Kimura, J. \& Schmid, R. D. 1992. Thin-film polyamine biosensor: substrate specificity and application to fish freshness determination. Analytica Chimica Acta. 263, 93-100.

Chemnitius, G. C. \& Bilitewski, U. 1996. Development of screen-printed enzyme electrodes for the estimation of fish quality. Sensors and Actuators B. 32, 107-113.

Clariana, M., Gratacós-Cubarsí, M., Hortós, M., García-Regueiro, J. A. \& Castellari, M. 2010. Analysis of seven purines and pyrimidines in pork meat products by ultra high performance liquid chromatography-tandem mass spectrometry. Journal of Chromatography A. 1217, 4294-4299.

Clark, L. C. \& Lyons, C. 1962. Electrode systems for continuous monitoring in cardiovascular surgery. Eds. L. C. Clark and C. Lyons. Annals of the New York Academy of Sciences. 102, 29-45.

Córdoba, J. J., Antequera-Rojas, T., García-González, C., Ventanas, B. J., López-Bote, C. \& Asensio, M. A. 1994. Evolution of free amino acids and amines during ripening of Iberian cured ham. Journal of Agriculture and Food Chemistry. 42, 2296-2301.

Colt, J. 1984. Computation of dissolved gas concentrations in water as functions of temperature, salinity and pressure. American Fisheries Society Symposium. $154 \mathrm{p}$.

Cremer, D. R. \& Eichner, K. 2000. The reaction kinetics for the formation of Strecker aldehydes in low moisture model systems and in plant powders. Food Chemistry. 71, 37-43.

Cruz, J. 2007. La evolución del sector productor de jamón curado en España. Eurocarne. 154, 29-40.

Dhananjaya, S. \& Stroud, G. D. 1994. Chemical and sensory changes in haddock and harring stored under modified atmosphere. International Journal of Food Science and technology. 29, 575-583. 
Dingle, J. R., Hines, J. A. \& Fraser, D. I. 1968. Post-mortem degradation of adenine nucleotides in muscle of Lobster, Homarus Americanus. Journal of Food Science. 33, 100-103.

Draisci, R., Volpe, G., Lucentini, L., Cecilia, A., Federico, R. \& Palleschi, G. 1998. Determination of biogenic amines with an electrochemical biosensor and its application to salted anchovies. Food Chemistry. 62, 225-232.

Dornelles, M. L. \& Tatsuo, K. L. 2002. Review of the use of biosensors as analytical tools in the food and drink industries. Food Chemistry. 77, 237-256.

Dzyadevych, S. V., Arkhypova, V. N., Soldatkin, A. P., El'skaya, A. V., Martelet, C. \& Jaffrezic-Renault, N. 2008. Amperometric enzyme biosensors: Past, present and future. ITBM-RBM. 29, 171-180.

Eerola, S., Roig Sagués, A-X., Lilleberg, L. \& Aalto, H. 1997. Biogenic amines in dry sausages during shelf-life storage. $Z$ Lebensm Unters Forsh A. 205, 351-355.

Eggins, B. 2002. Chemical sensor and biosensor. Ed. John Wiley \& Sons Ltd. England. $291 p$.

Estévez, M., Morcuende, D. \& Ventanas, S. 2009. Determination of oxidation. In: Handbook of processed meats and poultry analysis. Eds. L. M. L. Nollet and F. Toldrá. pp 141-162. CRC Press, Taylor \& Francis Group. Boca Ratón, FL, USA.

Escribano, J., García-Canovas, F. \& García-Carmona, F. 1988. A kinetic study of hypoxanthine oxidation by milk xanthine oxidase. Biochemistry Journal. 254, 829-833.

Fadda, S., Oliver, G., \& Vignolo, G. 2002. Protein degradation by Lactobacillus plantarum and Lactobacillus casei in a sausage model system. Journal of Food Science. 673, 1179-1183.

Fadda, S., López, C. \& Vignolo, G. 2010. Role of lactic acid bacteria during meat conditioning and fermentation: Peptides generated as sensorial and hygienic biomarkers. Meat Science. 86, 66-79.

Falck, D. 1997. Amperometric oxygen electrodes. Current Separations. 16, 19-22. 
Fernández, E., Romero-Rodríguez, M. A., Vázquez-Oderiz, M. L. Physicochemical and sensory properties of Galician Chorizo sausage preserved by refrigeration, freezing, oil-inmmersion, or vaccum-packing. Meat Science. 58, 99-104.

Flores, J. \& Bermell, S. 1984. Propiedades funcionales de las proteínas miofibrilares: capacidad de retención de agua. Revista de Agroquímica y Tecnología de Alimentos. 24, 151-158.

Flores, J. \& Toldrá, F. 1993. Curing: Processes and applications. In: Encyclopedia processing of foods science, food technology and nutrition. Eds. R. Macrae, R. Robinson, M. Sadle and G. Fullerlove. Academic Press, London.

Flores, J., Marcus, J. R., Nieto, P., Navarro, J. L. \& Lorenzo, P. 1997. Effect of processing conditions on proteolysis and taste of dry-cured sausages. Zeitschrift für Lebensmittel- Untersuchung und - Forschung A. 204, 168-172.

Flores, M., Spanier, A. M. \& Toldrá, F. 1998. Flavour analysis of dry-cured ham. In: Flavour of meat, products and seafood. Ed F. Shahidi. pp 320-341. Blackie A\&P, Chapman and Hall. London, UK.

Flores, M., Armero, E., Aristoy, M. C. \& Toldrá, F. 1999. Sensory characteristic of cooked pork lion as affected by nucleotide content and postmortem meat quality. Meat Science. 51, 53-59.

Flores, M., Moya, V-J., Aristoy, M. C. \& Toldrá, F. 2000. Nitrogen compounds as potencial biochemical markers of pork meat quality. Food Chemistry. 69, 371-377.

Frébort, I., Skoupa, L. \& Pec, P. 2000. Amine oxidase-based flow biosensor for the assessment of fish freshness. Food Control. 11, 13-18.

Fujita, T., Hori, Y., Otani, T., Kunita, Y., Sawa, S., Sakai, S., Tanaka, Y., Takagahara, I. \& Nakatani, Y. 1988. Applicability of the Ko value as an index of freshness for porcine and chicken muscles. Agricultural and Biological Chemistry. 52, 107112.

García, C., Berdagué, J. L., Antequera, T., López-Bote, C., Córdoba, J. J. \& Ventanas, J. 1991. Volatile compounds of dry cured iberian ham. Food Chemistry. 41, 2332. 
Gao, R. C., Xue, C. H., Yuan, L., Li, Z. J., Xue, Y., Cui, F. X. \& Sun, Y. 2006. Determination of the big head carp myofibrillar aristichthys nobilis adenosine triphosphatase activity by ion chromatography. Journal of Chromatography A. 1118, 278-280.

Gençcelep, H., Kaban, G. \& Kaya, M. 2007. Effects of starter cultures and nitrite levels on formation of biogenic amines in sucuk. Meat Science. 77, 424-430.

Geng, T., Morgan, M. T. \& Bhunia, A. K. 2004. Detection of low levels of Listeria monocytogenes cells by using a fiber-optic immunosensor. Applied and Evironmental Microbiology. 70, 6138-6146.

Gerard, M., Chaubey, A. \& Malhotra, B. D. 2002. Application of conducting polymers to biosensors. Biosensors and Bioelectronics. 17, 345-359.

Gimeno, O., Astisaran, I. \& Bello, J. 1999. Influence of partial remplacement of $\mathrm{NaCl}$ with $\mathrm{KCl}$ and $\mathrm{CaCl}_{2}$ on texture and color of dry fermented sausages. Journal of Agricultural and Food Chemistry. 47, 873-877.

Ghosh, S., Sarker, D. \& Misra, T. N. 1998. Development of an amperometric enzyme electrode biosensor for fish freshness detection. Sensor and Actuators B. 53, 58-62.

Greaser, M. I. 1986. Conversion of muscle to meat. In: Muscle as Food. Ed. P. J. Bechrel. pp 37-102. Academic Press, Orlando, FL, USA.

González, E., Pariente, F., Lorenzo, E. \& Hernández, L. 1991. Amperometric sensor for hypoxanthine and xanthine based on the detection of uric acid. Analytica Chimica Acta. 242, 267-273.

Halász, A., Baráth, A., Simon-Sarkadi, L. \& Holzapfel, W. 1994. Biogenic amines and their production by microorganisms in food. Trends in Food Science and Technology. 5, 42-49.

Hamm, R. 1977. Postmortem breakdown of ATP and glycogen in ground muscle: a review. Meat Science. 1, 15-39.

Hammes, W. P., Haller, D. \& Gänzle, M. G. 2003. Fermented meat. In: Handbook of fermented fuctional foods. Ed. E. R. Farnworth. pp. 291-320. CRC Press. Taylor \& Francis Group. Boca Ratón, FL, USA. 
Haouz, A., Geloso-Meyer, A., Burstein, C. 1994. Assay of dehydrogenases with an $\mathrm{O}_{2}-$ consuming biosensor. Enzyme and Microbial Technology. 16, 292-297.

Hattula, T. \& Kiesvaara, M. 1996. Breakdown products of adenosine triphosphate in heated fishery products as an indicator of raw material freshness and of storage quality. Lebensmittel-Wissenschaft und Technologie. 29, 135-139.

Hernández-Jover, T., Izquierdo-Pulido, M., Veciana-Nogués, M. T., Mariné-Font, A. \& Vidal-Carou, M. C. 1996. Ion pair high performance chromatographic determination of biogenic amines in meat and meat products. Journal Agricultural Food Chemistry. 44, 2710-2715.

Hernández-Jover, T., Izquierdo-Pulido, M., Veciana-Nogués, M. T., Mariné-Font, A. \& Vidal-Carou, M. C. 1997. Biogenic amine and polyamine contents in meat and meat products. Journal Agricultural Food Chemistry. 45, 2098-2102.

Honikel, K. O. \& Fischer, C. A. 1977. A rapid method for the detection of PSE and DFD porcine muscle. Journal Food Science. 42, 1633-1636.

Hu, S. \& Liu, C. C. 1997. A bienzyme sensor for the determination of hypoxanthine and inosine. Electroanalysis. 15, 1174-1179.

Hu, S., Xu, C., Luo, J., Luo, J. \& Cui, D. 2000. Biosensor for detection of hypoxanthine based on xanthine oxidase immobilized on chemically modified carbon paste electrode. Analytical Chimica Acta. 412, 55-61.

Jezewska, M. M. 1973. Xanthine accumulation during hypoxanthine oxidation by milk xanthine oxidase. Euopean Journal of Biochemistry. 36, 385-390.

Jiménez, C. C. \& León, P. D. 2009. Biosensores: aplicaciones y perspectivas en el control y calidad de procesos y productos alimentarios. Revista de la Facultad de Química Farmacéutica. 16, 144-154.

Jones, N. R., Murray, C. K., Livingst, E. I. \& Murray, J. 1964. Rapid estimations of hypoxanthine concentrations as indices of freshness of chill-stored fish. Journal of the Science of Food and Agriculture. 15, 763-774.

Karube, I., Satoh, I., Araki, Y. \& Suzuki, S. 1980. Monoamine oxidase electrode in freshness testing of meat. Enzyme and Microbial Technology. 2, 117-120. 
Karube, I., Matsuoka, M., Suzuki, S., Watanabe, E. \& Toyoma, K. 1984. Determination of fish freshness with an enzyme sensor system. Journal Agricultural Food Chemical. 32, 314-319.

Kauffman, R. G., Cassens, R. G., Sherer, A. \& Meeker, D. L. 1992. Variations in pork quality. pp. 1-8. NPPC Publication, Des Moines, USA.

Kauffman, R. G., Sybesma, W., Smulders, F. J. M., Eikelenboom, G., Engel, B., Van Lack, R. L. J. M., Hoving-Bolink, A. H., Sterrenburg, P., Nordheim, E. V., Walstra, P. \& Van der Wal, P. G. 1993. The effectiveness of examining early post-mortem musculature to predict ultimate pork quality. Meat Science. 34, 283-300.

Kassemsarn, B., Perez, B. S., Murray, J. \& Jones, N. R. 1963. Nucleotide degradation in the muscle of Iced haddock (Gadus aeglefinus), Lemon sole (Pleuronectes microcephalus) and Plaice (Pleuronectes platessa). Journal of Food Science. 28, 28-37.

Kemp, C. M., Sensky, P. L., Bardsley, R. G., Buttery, P. J. \& Parr, T. 2010. Tenderness An enzymatic view. Meat Science. 84, 248-256.

Keow, C. M., Abu, B. F., Bakar, S. A., Heng, L. Y., Wagiran, R. \& Sim, B. L. 2007. An amperometric biosensor for the rapid assessment of histamine level in tiger prawn (Penaeus monodon) spoilage. Food Chemistry. 105, 1636-1641.

Kivirand, K. \& Rinken, T. 2009. Influence of simultaneous presence of different biogenic amines on the response of an amine oxidase-based biosensor. Analytical Letters. 42, 1725-1733.

Koohmaraie, M. 1994. Muscle proteinases and meat aging. Meat Science. 36,93-104.

Koohmaraie, M. \& Geesink, G. H. 2006. Contribution of postmortem muscle biochemistry to the delivery of consistent meat quality with particular focus on the calpain system. Meat Science. 74, 34-43.

Kuchiba, M., Kaizaki, S., Matoba, T. \& Hasegawa, K. 1990. Depressing effect of salts on thermal-degradation of inosine $5^{\prime}$-monophosphate and guanosine-5'monophosphate in aqueous-solution. Journal of Agricultural and Food Chemistry. 38, 593-598. 
Kuda, T., Fujita, M., Goto, H. \& Yano, T. 2007. Effects of freshness on ATP-related compounds in retorted chub mackerel Scomber japonicus. Lwt-Food Science and Technology. 40, 1186-1190.

Kvasnicka, F. \& Voldrich, M. 2006. Determination of biogenic amines by capillary zone electrophoresis with conductometric detection. Journal of Chromatography A. 1103, 145-149.

Lange, J. \& Wittmann, C. 2002. Enzyme sensor array for the determination of biogenic amines in food samples. Analytical and Bioanaytical Chemistry. 373, 276-283.

Lamb, J. D. \& Ye, Y. K. 1992. Separation of nucleotides and nucleosides by gradient macrocycle-based ion chromatography. Journal of Chromatography. 602, 189-195.

Latorre-Moratalla, M. L., Bover-Cid, S., Veneciana-Nogués, T. \& Vidal-Carou, M. C. 2009. Thin-layer chromatography for the identification and semiquantification of biogenic amines produced by bacteria. Journal of Chromatography A. 1216, 4128-4132.

Latorre-Moratalla, M. L., Bover-Cid, S., Talon, R., Garriga, M., Zanardi, E., Lanieri, A., Fraqueza, M. J., Elias, M., Drosinos, E. H. \& Vidal-Carou, M. C. 2010a. Strategies to reduce biogenic amine accumulation in traditional sausage manufacturing. LWT-Food Science and Technology. 43, 20-25.

Latorre-Moratalla, M. L., Bover-Cid, S. \& Vidal-Carou, M. C. 2010b. Technological conditions influence aminogenesis during spontaneous sausage fermentation. Meat Science. 85, 537-541.

Leistner, F. 1992. The essentials of producing stable and safe raw fermented sausages. In: New technologies for meat and meat Products. Eds., F.J.M. Smulders, F. Toldrá', J. Flores, and M. Prieto. pp. 1-19. M. Ecceamst, Audet Tijdschrften, Nijmegen, The Netherlands.

Luong, J. H. T. \& Male, K. N. 1992. Development of a new biosensor system for the determination of the hypoxanthine ratio, an indicator of fish freshness. Enzyme and Microbial Technology. 14, 125-130. 
Luong, J. H. T. \& Gibbs, B. F. 1996. Amperometric biosensor for total histamine, putrescine and cadaverina usisng diamine oxidase. Journal of Food Science. 61, 1012-1016.

Luong, J. H. T., Bouvrette, P. \& Male, K. B. 1997. Developments and applications of biosensor in food analysis. Tibtech. 15, 369-376.

Lücke, F. K. 1994. Fermented meat products. Food Research International. 27, 299307.

Macy, R. L., Naumann, H. D. \& Bailey, M. E. 1970. Water-soluble flavor and odor precursors of meat. 5. Influence of heating on acid-extractable nonnucleotide chemical constituents of beef, lamb and pork. Journal of Food Science. 35, 81-86.

Maijala, R. \& Eerola, S. 1993. Contaminant lactic acid bacteria of dry sausages produce histamine and tyramine. Meat Science. 39, 387-395.

Maijala, R., Eerola, S., Lievonen, S., Hill, P. \& Hirvi, T. 1995. Formation of biogenic amines during ripening of dry sausages as affect by starter cultures and thawing time of raw materials. Journal of Food Science. 69, 1187-1190.

Male, K. B., Bouvrette, P., Luong, J. H. T. \& Gibbs, B. F. 1996. Amperometric biosensor for total histamine, putrescine and cadaverine using diamine oxidase. $r$ assaying postmortem nucleotide degradation in fish tissues. Journal of Food Science. 61, 1012-1016.

Maltin, C., Balcerzak, D., Tilley, R., \& Delday, M. 2003. Determinants of meat quality: Tenderness. Proceedings of the Nutrition Society. 62, 337-347.

Marchesini, B., Bruttin, A., Romailler, N., Moreton, R. S., Stuchi, C. \& Sozzi, T. 1992. Microbiological events during commercial meat fermentations. Journal Applied Bacteriology. 73, 203-209.

Marco, A., Navarro, J. L. \& Flores, M. 2006. The influence of nitrite and nitrate on microbial, chemical and sensory parameters of slow dry fermented sausage. Meat Science. 73, 660-673. 
Massa, A. E., Paredi, M. E., Crupkin, M. 2002. Nucleotide catabolism in cold stored adductor muscle of scallop (Zygochlamys patagonica). Journal of Food Biochemistry. 26, 295-305.

Mateo, J., Dominguez, M. C., Aguirrezábal, M. M. \& Zumalacárregui, J. M. 1996. Taste compounds in chorizo and their changes during ripening. Meat Science. 44, 245-254.

Mello, L. D. \& Kubota, L. T. 2002. Review of the use of biosensores as analytical tools in the food and drink industries. Food Chemistry. 77, 237-256.

Meynial, I., Paquet, V. \& Combes, D. 1995. Simultaneous separation of nucleotides and nucleotide sugars using an ion-pair reversed-phase HPLC - application for assaying glycosyltransferase activity. Analytical Chemistry. 67, 1627-1631.

Mikkelsen, S. R. \& Rechnitz, G. A. 1989.Conductometric transducer for enzyme-bases biosensor. Analitical Chemistry. 61. 1737-1742.

Mondovi, B., Rotilio, G., Costa, M. T. \& Agro, A. F. 1971. Diamine oxidase (Pig kidney) In: Methods Enzymology, XVII, Part B. Eds. Tabor H., Tabor C. W. pp 735-740. Academic Press, New York, USA.

Montel, M. C., Masson, F. \& Talon, R. 1998. Bacterial role in flavour development. Meat Science. 49, 111-123.

Mora, L., Hernández-Cázares, A. S., Sentandreu, M. A. \& Toldrá, F. 2009. Creatine and creatinine evolution during the processing of dry-cured ham. Meat Science. 84, 384-389.

Motilva, M. J., Toldrá, F., Nieto, P. \& Flores, J. 1993. Muscle lipolysis phenomena in the processing of dry-cured ham. Food Chemistry. 48, 121-125.

Mottram, D. S. 1998. Flavour formation in meat and meat products: a review. Food Chemistry. 62, 415-424.

Mulchandani, A., Luong, J. H. T. \& Male, K. B. 1989. Development and application of a biosensor for hypoxanthine in fish extract. Analytical Chimica Acta. 221, 215-222. 
Mulchandani, A., Male, K. B. \& Luong, J. H. T. 1990. Development of a biosensor for assaying postmortem nucleotide degradation in fish tissues. Biotechnology and Bioengineering. 35, 739-745.

Murray, J. \& Thomson, A. B. 1983. Reverse phase ion-pair separation of nucleotides related products in fish muscle. Journal of High Resolution Chromatography \& Chromatography Communications. 6, 209-210.

Nakatani, H. S., Dos Santos, L. V., Peralta, P., Marques, G. S., Matsushita, M., de Souza, E. N. \& Visentainer, J. V. 2005. Biosensor based on xanthine oxidase for monitoring hypoxanthine in fish meat. American Journal of Biochemistry and Biotechnology. 1, 85-89.

Nakatani, Y., Fujita, T., Sawa, S., Otani, T., Hori, Y. \& Takagahara, I. 1986. Changes in ATP-related compounds of beef and rabbit muscles and a new index of freshness of muscle. Agriculture and Biological Chemistry. 50, 1751-1756.

Nanjyo, Y. \& Yao, T. 2002. Rapid measurement of fish freshness indices by an amperometric flow-injection system with a 16-way switching valve and immobilized enzyme reactors. Analytica Chimica Acta. 470, 175-183.

Navarro, J. L., Nadal, M. I., Izquierdo, L. \& Flores, J. 1997. Lypolysis in dry cured sausages as affected by processing conditions. Meat Science. 45, 161-168.

Nelson, D.L. \& Cox, M. M. 2001. Lehninger. Principios de Bioquímica. Editorial Omega. $1264 \mathrm{p}$.

Nguyen, A. L., Luong, J. H. T. \& Masson, C. 1990. Determination of Nucleotides in Fish-Tissues Using Capillary Electrophoresis. Analytical Chemistry. 62, 24902493.

Nguyen, T. T. \& Sporns, P. 1985. Composition of flavour enhancers, monosodium glutane, inosine-5'-monophosphate and guanosine-5'-monophosphate during canning. Journal of food Science. 50, 812-814.

Niculescu, M., Frébort, I., Peć, P., Galuszka, P., Mattiasson, B. \& Csöregi, E. 2001. Amine oxidase based amperometric biosensore for histamine detection. Electroanalysis. 12, 369-375. 
Niculescu, M., Nistor, C., Frébort, I., Peć, P., Mattiasson, B. \& Csöregi, E. 2000. Redox hydrogel-based amperometric bienzyme electrodes for fish freshness monitoring. Analytical Chemistry. 72, 1591-1597.

Nishimura, T. 2002. Influence of peptides produced during postmortem conditioning on improvement of meat flavor. In: Research advances in the quality of meat and meat products. Ed F. Toldrá. pp. 65-78. Research Signpost.Trivandrum, India.

Numata, M., Funazaki, N., Ito, S., Asano, Y. \& Yano, Y. 1996. Flow-injection análisis for hipoxanthine in meat with dissolved oxygen detector and enzyme reactor. Talanta. 43, 2053-2059.

Nunes, G. S. \& Marty, J-L. 2006. Immobilization of enzymes on electrodes. In: Methods in Biotechnology. Ed J. M. Guisan. pp 239-250. Humana Press Inc., Totowa, NJ, USA.

Okuma, E. \& Abe, H. 1992. Major buffering constituents in animal muscle. Comparative Biochemistry and Physiology A-Physiology. 102, 37-41.

Okuma, H. \& Watanabe, E. 2002. Flow system for fish freshness determination based on double multi-enzyme reactor electrodes. Biosensores and Bioelectronics. 17, 367-372.

Okuma, H., Takahashi, H., Yasawa, S. \& Sekimukai, S. 1992. Development of a system with double enzyme reactors for the determination of fish freshness. Analytica Chimica Acta. 260, 93-98.

Olivares, A., Navarro, J. L. \& Flores, M. 2009. Establishment of the contribution of volatile compounds to the aroma of fermented sausages at different stages of processing and storage. Food Chemistry. 115, 1464-1472.

Önal, A. 2007. A review: Current alaytical methods for the determination of biogenic amines in foods. Food Chemistry. 103, 1475-1486.

Ouali, A. \& Sentandreu, M. A. 2002. Overview of muscle peptidases and their potential role in meat texture development. In: Research advances in the quality of meat and meat products. Ed. F. Toldrá. pp. 33-63. Research Signpost. Trivandrum, India. 
Özogul, F. K., Taylor, A., Quantick, P., \& Özogul, Y. 2000. A rapid HPLC-determination of ATP-related compounds and its application to herring stored under modified atmosphere. International Journal of Food Science and Technology. 35, 549-554.

Özogul, F. \& Özogul, Y. 2006. Biogenic amine content and biogenic amine quality indices of sardines (Sardina pilchardus) stored in modified atmosphere packaging and vacuum packaging. Food Chemistry. 99, 574-578.

Parente, E., Martuscelli, M., Gardini, F., Grieco, S., Crudele, M. A. \& Suzzi, G. 2001. Evolution of microbial populations and biogenic amine production in dry sausages produced in southern Italy. Journal of Applied Microbiology. 90, 882-891.

Park, I-S. \& Kim, N. 1999. Simultaneous determination of hypoxanthine, inosine and inosine $5^{\prime}$-monophosphate with serially connected three enzyme reactors. Analytica Chimica Acta. 394, 201-210.

Park, I-S., Cho, Y-J \& Kim, N. 2000. Characterization and meat freshness application of a serial three-enzyme reactor system measuring ATP-degradative compounds. Analytica Chimica Acta. 404, 75-81.

Prodromidis, M. I. \& Karayannis, M. I. 2002. Enzyme based amperometric biosensors for food analysis. Electroanalysis. 14, 241-261.

Qiong, C. Tukzhi, P. \& Liju, Y. 1998. Silk fibron/cellulose acetate membrane electrodes incorporating xanthine oxidase for the determination of fish freshness. Analytical Chimica Acta. 369, 245-251.

Radke, S. M. \& Alocilja, E. C. 2005. A high density microelectrode array biosensor for detection of E. coli 0157:H7. Biosensors and Bioelectronics. 20, 1662-1667.

Rahma, M. A., Won, M-S. \& Shim, Y-B. 2007. Xanthine sensors based on anodic and cathodic detection of enzymatically generated hydrogen peroxide. Electroanalysis. 6, 631-637.

Reviejo, A. J. \& Pingarrón, J. M. 2000. Biosensores electroquímicos. Una herramienta útil para el análisis medioambiental, alimentario y clínico. pp. 5-15. Anales de la Real Sociedad Española de Química. España. 
Roberts, B., Morris, B. A. \& Clifford, M. N. 1991. Comparison of radioimmunoassay and spectrophotometric analysis for the quantitation of hypoxanthine in fish muscle. Food Chemistry. 42, 1-17.

Roncalés, P. 1994. Tecnología, cambios bioquímicos y calidad sensorial de los embutidos curados. En: Tendencias en el curado de productos cárnicos. Eds. J. Flores, S. Bermell y F. Toldrá. pp 87-109. Expocarne. España.

Ruiz-Capillas, C. \& Jiménez-Colmenero, F. 2004. Biogenic amines in meat and meat products. Critical Review in Food Science and Nutrition. 44, 489-499.

Ruusunen, M. \& Puolanne, E. 2005. Reducing sodium intake from meat products. Meat Science. 70, 531-541.

Saito, T., Araki, K. \& Matsuyoshi, M. 1959. A new method for estimating the freshness of fish. Bulletin of the Japanese Society of Scientific Fisheries. 24, 749-750.

Santandreu, M. A., Coulis, G. \& Ouali, A. 2002. Role of muscle endopeptidase and their inhibitors in meat tenderness. Trends in Food Science and Technology. 13, 398-419.

Santos, W. Jr., Lima, P. R., Tanaka, A. A., Tanaka, S. \& Kubota, L. T. 2009. Determination of nitrite in food samples by anodic voltammetry using a modified electrode. Food Chemistry. 113, 1206-1211.

Sanz, Y., Vila, R., Toldrá, F. \& Flores, J. 1998. Effect of nitrate and nitrite curing salts on microbial changes and sensory quality of non-fermented sausages. International Journal of Food Microbiology. 42, 213-217.

Sanz, Y. S., Fadda, S., Vignolo, G., Aristoy, M. C., Oliver, G. \& Toldrá, F. 1999. Hydrolysis of muscle proteins by Lactobacillus curvatus and Lactobacillus sake. International Journal of Food Microbiology. 53, 115-125.

Sanz, Y. S., Sentandreu, M. A. \& Toldrá, F. 2002. Role of muscle and bacterial exopeptidases in meat fermented. In: Research advances in the quality of meat and meat products. Ed. F. Toldrá. pp. 33-63. Research Signpost. Trivandrum, India. 
Scheffler, T. L. \& Gerrard, D. E. 2007. Mechanisms controlling pork meat quality development: The biochemistry controlling postmortem energy metabolism. Meat Science. 77, 7-16.

Schweigert, B. S. 1994. Contenido en nutrientes y valor nutritivo de la carne y los productos cárnicos. En: Ciencia de la carne y de los productos cárnicos. Eds. S. A. Price y B. S.Schweigert Acribia S. A., Zaragoza, España.

Shahidi, F., Chong, X. \& Dunajski, E. 1994. Freshness quality of harp Seal (Phoca groenlandica) meat. Journal Agricultural Food Chemistry. 42, 868-872.

Shalaby, A. R. 1996. Significance of biogenic amines to food safety and human health. Food Research International. 29, 675-690.

Sharma, S. K., Sehgal, N. \& Kumar, A. 2003. Biomolecules for development of biosensors and their applications. Current Applied Physics. 3, 307-316.

Shen, L., Yang, L. \& Peng, T. 1996. Amperometric determination of fish freshness by a hipoxanthine biosensor. Journal of the Science Food and Agriculture. 70, 298-302.

Shin, S. J., Yamanaka, H., Endo, H. \& Watanabe, E. 1998. Development of an octopine biosensor and its application to the estimation of scallop freshness. Enzyme and Microbiology. 23, 10-13

Shizuko, N. H., Peralta, P. C. \& Márquez, G. S. 2005. Biosensor based on xanthine oxidase for monitoring hypoxanthine in fish meat. American Journal of Biochemistry and Biotechnology. 12, 85-89.

Silla-Santos, M. H. 1996. Biogenic amines: their importance in foods. International Journal of Food Microbiology. 29, 213-231.

Smith, P.K., Krohn, R. I., Hermanson, G. T., Mallia, A. K., Gatner, F. H. \& Provenzano, M. D. 1985. Mesurement of protein using bicinchoninic acid. Analytical Biochemistry. 150, 76-85.

Staruszkiewicz, W. F. Jr. \& Bond, J. F. 1981. Gas chromatographic determination of cadaverine, putrescine and histamine in foods. Journal - Association of Official Analytical Chemists. 64, 584-591. 
Surette, M. E., Gill, T. A. \& LeBlanc, P. J. 1988. Biochemical basis of postmortem nucleotide catabolism in cod Gadus morhua and its relationship to spoilage. Journal of Agricultural and Food Chemistry. 36, 19-22.

Suzzi, G. \& Gardini, F. 2003. Biogenic amines in dry fermented sausages: A review. International Journal of Food Microbiology. 88, 41-54.

Taniwaki, M., Hanada, T. \& Sakurai, N. 2006. Device for acoustic measurement of food texture using a piezoelectric sensor. Food Research International. 39, 1099-1105.

te Pas, M. F. W., Jansen, J., Broekman, K. C. J. A., Reimert, H. \& Heuven, H. C. M. 2009. Postmortem proteome degradation profiles of longissimus muscle in Yorkshire and Duroc pigs and their relationship with pork quality traits. Meat Science. 83, 744-751.

Terry, L. A., White, S. F. \& Tigwell, L. 2005. The application of biosensors to fresh produce and the wider food industry. Journal Agricultural Food Chemistry. 53, 1309-1316.

Thévenot, D. R., Toth, K., Durst, R. A. \& Wilson, G. S. 2001. Electrochemical biosensors: recommended definitions and classification. Biosensors and Bioelectronics. 16, 121-131.

Tikk, M., Tikk, K., Torngren, M. A., Meinert, L., Aaslyng, M. D., Karlsson, A. H. \& Andersen, H. J. 2006. Development of inosine monophosphate and its degradation products during aging of pork of different qualities in relation to basic taste and retronasal flavor perception of the meat. Journal of Agricultural and Food Chemistry. 54, 7769-7777.

Todoriki, S., Tajima, M. \& Senda, M. 1988. Enzymatic oxygen electrode method for determination of polyamines in foods. Analytical Sciences.4, 583-585.

Toldrá, F., Rico, E. \& Flores, J. 1992. Activities of pork muscle proteases in model cured meat systems. Biochimie. 74, 291-296.

Toldrá, F., Rico, E. \& Flores, J. 1993. Cathepsin B, D, H and L activities in the processing of dry-cured ham. Journal Science Food and Agriculture. 62, 157161. 
Toldrá, F. 1994. Basic principles of the development of aroma and flavour of meat and meat products. Alimentación Equipos y Tecnología. 13, 59-62.

Toldrá, F., Flores, M. \& Sanz, Y. 1997. Dry-cured ham flavour: Enzymatic generation and process influence. Food Chemistry. 59, 523-530.

Toldrá, F. \& Flores, M. 1998. The role of muscle proteases and lipases in flavor development during the processing of dry-cured ham. Critical Reviews in Food Science and Nutrition. 38, 331-354.

Toldrá, F. 1998. Proteolysis and lipolysis in flavour development of dry-cured meat. Meat Science. 49, 101-110.

Toldrá, F. \& Flores, M. 2000. The use of muscle enzymes as predictors of pork meat quality. Food Chemistry. 69, 387-395.

Toldrá, F., Aristoy, M. C. \& Flores, M. 2000. Contribution of muscle aminopeptidases to flavor development in dry-cured ham. Food Research International. 33, 181-185.

Toldrá, F. 2002. Dry-cured meat products. 244 p. Food and Nutrition Press, INC. Trumbul, Connecticut, USA.

Toldrá, F. 2006a. Meat: Chemistry and Biochemistry. In: Handbook of Food Science, Technology and Engineering. Ed Y. H., Hui. pp 28-1 - 28-18. CRC Press, Boca Ratón, FL, USA.

Toldrá, F. 2006b. Dry-cured ham. In: Handbook of Food Science, Technology and Engineering. Ed. Y. H., Hui. pp 164-1- 164-11. CRC Press, Boca Ratón, FL, USA.

Toldrá, F. 2008. Biotechnology of flavour generation in fermented meats. In: Meat Biotechnology. Ed. F. Toldrá. Chapter 9, pp. 199-215. Springer Science + Business Media. Spring street, New York, NY, USA.

Toldrá, F. \& Aristoy, M. C. 2010. Dry-cured ham. In: Handbook of meat processing. Ed. F. Toldrá. pp 351-362. Willey-Blackwell. Ames, lowa, USA.

Tombelli, S. \& Mascini, M. 1998. Electrochemical biosensor for biogenic amines: a comparison between different approaches. Analytica Chimica Acta. 358, 277-284. 
Turner, A. P. F., Karube, I. \& Wilson, G. S. 1987. Biosensor: Fundamental and applications. Oxford University Press, Oxford. 770p.

Tsai, R., Cassens, R. G., Briskey, E. J. \& Greaser, M. L. 1972. Studies on nucleotide metabolism in porcine Longissimus muscle postmortem. Journal of Food Science. 37, 612-616.

Urich, K. 1990. Small nitrogen compound. In: Comparative animal biochemistry. pp 403-454. Springer-Verlag, Berlin.

Van den Thillart, G., Van Waarde, A., Muller, H. J., Erkelens, C. \& Lugtenburg, J. 1990. Determination of high-energy phosphate compounds in fish muscle: ${ }^{31} \mathrm{P}-\mathrm{NMR}$ spectroscopy and enzymatic methods. Comparative Biochemistry and Physiology Part B: Comparative Biochemistry. 95, 789-795.

Vani, N. D., Modi, V. K., Kavitha, S., Sachindra, N. M. \& Mahendrakar, N. S. 2006. Degradation of inosine-5'-monophosphate IMP in aqueous and in layering chicken muscle fibre systems: Effect of $\mathrm{pH}$ and temperature. LWT - Food Science and Technology. 39, 627-632.

Vázquez, R. L. \& Vanaclocha, A. C. 2004. Tecnología de Mataderos. Mundi-prensa Libros, S. A., Madrid España.

Veciana-Nogués, M. T., Hernández-Jover, T., Marine-Font, A. \& Vidal-Carou, M. C. 1995. Liquid chromatographic method for determination of biogenic amines in fish and fish products. Jounal AOAC International. 78, 1045-1050.

Veciana-Nogués, M. T., Izquierdo-Pulido, M. \& Vidal-Carou, M. C. 1997. Determination of ATP related compounds in fresh and canned tuna fish by HPLC. Food Chemistry. 59, 467-472.

Ventanas, J., Córdoba, J. J., Antequera, T., García, C., López-Bote, C. \& Ascencio, M. A. 1992. Hydrolysis and Maillard reactions during ripening of Iberian ham. Journal Food Science. 57, 813-815.

Venugopal, V. 2002. Biosensors in fish production and quality control. Biosensors and Bioelectronics. 17, 147-157. 
Vidal-Carou, M. C., Izquierdo-Pulido, M. L., Martín-Morro, M. C., Mariné-Font, A. 1990. Histamine and tyramine in meat products: relationship with meat spoilage. Food Chemistry. 37, 239-249.

Volpe, G. \& Mascini, M. 1996. Enzyme sensors for determination of fish freshness. Talanta. 43, 283-289.

Warner, R. D., Kauffman, R. G. \& Greaser, M. L. 1997. Muscle protein changes post mortem in relation to pork quality traits. Meat Science. 45, 339-352.

Warthesen, J. J., Waletzko, T. P. \& Busta, F. F. 1980. High performance liquid chromatografic determination of hypoxanthine in refrigerated fish. Journal of agricultural and Food Chemistry. 28, 1308-1309.

Watanabe, E., Ando, K., Karube, I., Matsuoka, H. \& Suzuki, S. 1983. Determination of hypoxanthine in fish meat with an enzyme sensor. Journal of Food Science. 48, 496-500.

Wimmerová, M. \& Macholán L. 1999. Sensitive amperometric biosensor for the determination of biogenic and synthetic amines using pea seedlings amine oxidase: a novel approach for enzyme immobilization. Biosensors and Bioelectronics. 14, 495-702.

Yano, Y., Kataho, N., Watanabe, M., Nakamura, T. \& Asano, Y. 1995a. Evaluation of beef aging by determination of hypoxanthine and xanthine contents: application of a xanthine sensor. Food Chemistry. 52, 439-445.

Yano, Y., Kataho, N., Watanabe, M. \& Nakamura, T. 1995b. Changes in the concentration of biogenic amines and application of tyramine sensor during storage of beef. Food Chemistry. 54, 155-159.

Yano, Y., Miyaguchi, N., Watanabe, M., Nakamura, T., Youdou, T., Miyai, J., Numata, M. \& Asano, Y. 1996. Monitoring of beef aging using a two-line flow injection analysis biosensor consisting of putrescine and xanthine electrodes. Food Research International. 6, 611-617.

Yao, T. 1993. Enzyme electrode for the successive detection of hypoxanthine and inosine. Analytica Chimica Acta. 281, 323-326. 
Yoshida, T. 2004. Peptide separation by hydrophilic-interaction chromatography: a review. Journal of Biochemical and Biophysical Methods. 60, 265-280. 

Anexos 



\section{Anexo A}



Hypoxanthine-based enzymatic for determination of pork meat

Aleida S. Hernández-Cázares, María-Concepción Aristoy, Fidel Toldrá

Food Chemistry, 123 (2010) 949-954 

Analytical Methods

Hypoxanthine-based enzymatic sensor for determination of pork meat freshness

Aleida S. Hernández-Cázares, María-Concepción Aristoy, Fidel Toldrá*

Instituto de Agroquímica y Tecnología de Alimentos (CSIC), Av. Agustín Escardino 7, P.O. Box 73, 46980 Paterna, Valencia, Spain

A R T I C L E I N F O

Article history:

Received in revised form 2 November 2009

Keywords:

Enzyme sensor
Hypoxanthine

Xanthine oxidase

Pork meat

\section{Introduction}

A large number of post-mortem reactions are initiated in meat glycolysis, proteolysis and lipolysis) immediately after the animal is slaughtered, which are critical to characterise the quality development Various methods based on the measurement of post-mortem deteriorative changes have been developed. One of the most important changes consists of the formation of nucleotide and important changes consists of the formation of nucleotide and
nucleoside metabolites resulting from the ATP (adenosine triphosphate) degradation (Toldrá, 2006). The reactions sequence from ATP to IMP (inosine monophosphate) develops rapidly (Batlle, Aristoy, \& Toldrá, 2000) and the generated IMP is further degraded to inosine (Ino) and hypoxanthine $(\mathrm{Hx})$, which are accumulated during the maturation process (Tasai, Cassens, Briskey, \& Greaser, 1972). Therefore, the evaluation of these compounds has been proposed as a rapid and simple method to determine the quality of meat or used as an index of meat freshness (Batlle, Aristoy, \& Toldrá, 2001; Cattaneo, Pagliaro, \& Cantoni, 1979; Scheffler \& Gerrard, 2007).

In recent years, the use of biosensors has been introduced as an alternative to conventional analytical methods, like HPLC, (Dornelles \& Tatsuo, 2002; Luong, Bouvrette, \& Male, 1997) due to its simplicity, rapidness and low cost (Dzyadevych et al., 2008). In particular, enzyme-based amperometric biosensors are the most commonly used in the quantitation of ATP-compounds (Luong et al., 1997: Venugopal, 2002), using the catalytic activity of the redox

\footnotetext{
* Corresponding author. Tel.: + 34 3900022x2112; fax: +34 3636301 E-mail address: ftoldra@iata.csic.es (F. Toldrá).
}

0308-8146/\$ - see front matter $\odot 2010$ Elsevier Ltd. All rights reserved. doi:10.1016/j.foodchem.2010.04.066 enzymes, either soluble or immobilised, involved in their degradative pathways: $\mathrm{ATP}_{\overrightarrow{1}} \mathrm{ADP}_{\overrightarrow{2}} \mathrm{AMP}_{3} \mathrm{IMP}_{\overrightarrow{4}} \operatorname{Ino} \underset{5}{\rightarrow} \mathrm{Hx} \underset{6}{\rightarrow} \mathrm{X}_{\overrightarrow{7}} \mathrm{UA}$; (where ADP, AMP, $X, U A$ are adenosine diphosphate, adenosine monophosphate, xanthine and uric acid, respectively, and 1: ATPase, 2: myokinase 3: AMP deaminase 4: nucleotidase, 5: nucleoside phosphorylase and 6-7: xanthine oxidase). Thus, the design of these biosensors has been based on: (i) the detection of consumed oxygen at negative potential $(-500$ to $-700 \mathrm{mV})$ or generated hydrogen peroxide $\left(\mathrm{H}_{2} \mathrm{O}_{2}\right)$ at positive potential $(600-650 \mathrm{mV})$ (Agüi, Manso, Yáñez-Sedeño, \& Pingarrón, 2006: Prodromidis \& Karayannis, 2002); (ii) the use of alternative oxidising agents, Karayannis, 2002); (ii) the use of alternative oxidising agents, called mediators; (iii) the direct electron transference between the enzyme
et al., 2008)

The application of the majority of these biosensors has been focused to the determination of different indexes for the control of fish or meat freshness, like the $K o$ value $((($ Ino $+\mathrm{Hx}+\mathrm{X})($ $(\mathrm{ATP}+\mathrm{ADP}+\mathrm{AMP}+\mathrm{IMP}+$ adenosine + Ino $\left.+\mathrm{HX}+\mathrm{X}))^{*} 100\right)$ (Fujit et al., 1998). However, the formation rate of X during the storage is slow because it mainly occurs through the action of enzymes from microbial metabolism. Thus, the determination of $K$ value $((($ Ino $+\mathrm{Hx}) /(\mathrm{ATP}+\mathrm{ADP}+\mathrm{AMP}+\mathrm{IMP}+\mathrm{Ino}+\mathrm{Hx})) * 100)$ had been suggested (Okuma \& Watanabe, 2002). But some metabolites such as ATP, ADP and AMP disappear around $24 \mathrm{~h}$ after the death of the \& Toyoma, 1984; Batlle et al., 2001). Therefore, the $K$ value was simplified to $K_{1}$ or $K^{\prime}$ value $\left(((\operatorname{Ino}+\mathrm{Hx}) /(\mathrm{IMP}+\operatorname{lno}+\mathrm{Hx}))^{*} 100\right)$ (Karube et al., 1984; Mulchandani, Male, \& Luong, 1990; Okuma, Takahashi, Yasawa, \& Sekimukai, 1992; Volpe \& Mascini, 1995 
In-Seon, Young-Jin, \& Namsso, 2000; Carsol \& Mascini, 1998); Hx ratio or $\mathrm{H}$ value $(\mathrm{Hx} /(\mathrm{IMP}+\mathrm{Ino}+\mathrm{Hx}))$ (Ghosh, Sarker, \& Misra, 1998; In-Seon et al., 2000; Luong \& Male, 1992) and $K_{2}$ values $\left((\mathrm{Hx} /(\mathrm{Ino}+\mathrm{Hx})) *{ }^{100}\right)($ Nanjyo \& Yao, 2002). These multienzymatic sensors are complex in design and difficult to use, and thus several researches have proposed the determination of just Hx as freshness index have been designed based on the enzyme reaction catalysed by the xanthine oxidase (XO) in the determination of $\mathrm{Hx}$ in fish (Mulchandani, Luong, \& Male, 1989; Nguyen, Luong, \& Yacynych, 1991; Shen, Yang, \& Peng, 1996; Watanabe, Ando, Karube, Matsuoka, \& Suzuki, 1983; Cayuela, Peña, Reviejo, \& Pingarrón, 1998; Hu, Xu, Luo, Luo, \& Cui, 2000; Nakatani et al., 2005; Oiong, Tukzhi, \& Liju, 1998) beef (Yano, Kataho, Watanabe, Nakamura \& Asano, 1995: Numata, Funazaki, Ito, Asano, \& Yano, 1996) and poultry (Fujita et al., 1998; In-Seon et al., 2000; Agüi et al., 2006).

In this context, two rapid and cheap enzyme sensors based on an oxygen electrode and either a xanthine oxidase-immobilised membrane (immobilised enzyme sensor) or a soluble xanthine oxidase (XO) (soluble enzyme sensor) using simple principles of construction and operation procedures for quantifying hypoxanthine are proposed. Therefore, the aim of this study is to evaluate the use of an enzyme sensor to determine the $\mathrm{Hx}$ content in pork meat samples at different post-mortem times as a measure of meat freshness.

\section{Materials and methods}

\subsection{Chemical and reagent}

Xanthine oxidase (E.C. 1.2.3.2. from bovine milk, $1.3 \mathrm{U} / \mathrm{mg}$ proteins, $\mathrm{XO}$ ), hypoxanthine $(\mathrm{Hx})$, xanthine $(\mathrm{X})$, uric acid $(\mathrm{UA})$, glutaraldehyde $(50 \%)$, L-cysteine and cellulose acetate were purchased from Sigma (St. Louis, MO, USA). Methanol, perchloric acid, potassium carbonate and acetone were from Scharlau (Barcelona, Spain). All the chromatographic reagents used were of HPLC grade. The preactivated immunodyne $\mathrm{ABC}$ membrane (Nylon 66, pore size $0.45 \mu \mathrm{m}$ ) was supplied by Pall Europe (Porsmounth, United Kingdom).

\subsection{Materials}

Samples of pork Longissimus dorsi muscle were obtained from four carcasses just slaughtered and immediately chilled at $4{ }^{\circ} \mathrm{C}$. During the sampling small slices were taken off from the muscles at different post-mortem times $(5,7,9,11,27,51$ and $171 \mathrm{~h})$, immediately frozen by immersion in liquid nitrogen and stored at $-20^{\circ} \mathrm{C}$ (Batlle et al., 2000, 2001).

\subsection{Equipment}

The amperometric measurement of hypoxanthine was carried out in an enzyme sensor, based on an oxygen electrode assembly (Rank Brothers, Bottisham, Cambridge, England) and a soluble or immobilised enzyme. The oxygen electrode consists of a central $2 \mathrm{~mm}$ diameter platinum disk (working electrode) with a surrounding silver ring $(\mathrm{Ag} / \mathrm{AgCl}$, reference electrode), a thermostated reaction cell and an oxygen permeable Teflon membrane $(12.7 \mu \mathrm{m})$. The current output was recorded by a datalogger ADC-16 (Tip Technology Limited, St. Net. Cambridgeshire, United Kingdom) and displayed as oxygen consumed $(\mathrm{mg} / \mathrm{L})$ during the Hx oxidation.

The chromatographic analysis was performed with a $1100 \mathrm{Agi-}$ lent liquid chromatograph (Agilent Technologies, Palo Alto, CA,
USA) equipped with a diode array detector used in the range of 195-300 nm.

\subsection{Sample preparation}

Frozen tissue samples $(5 \mathrm{~g})$ were ground and homogenised with cold $0.6 \mathrm{M}$ perchloric acid ( $15 \mathrm{~mL}$ ) for 4 min at $4{ }^{\circ} \mathrm{C}$ in a stomacher (IUL Instrument, Barcelona, Spain) (Burns \& Ke, 1985). The extract was centrifuged at $10,000 \mathrm{~g}$ for $20 \mathrm{~min}$ in cold $\left(4^{\circ} \mathrm{C}\right)$ and the supernatant filtered through glass wool. Twelve milliliter of this solution was neutralised ( $\mathrm{pH} \mathrm{6.5-7)}$ by adding solid potassium carbonate and allowed to stand in an ice bath for $30 \mathrm{~min}$. The supernatant was stored at $-20^{\circ} \mathrm{C}$ until use. The meat extract was thawed before injection, centrifuged as described above for $5 \mathrm{~min}$ and used for the analysis by HPLC and by the enzyme sensor.

2.5. Preparation of the enzyme sensor and measurement of $\mathrm{Hx}$

In order to get an electrical bridge between the platinum and silver ring, a damp paper tissue with an alkaline electrolyte (3 M $\mathrm{KCl}$ ) covering both electrodes was used in the oxygen sensor. An oxygen permeable Teflon membrane was placed over this paper. Subsequently, the system was clamped into a thermostated reaction cell and the potential of polarisation was fixed at $-600 \mathrm{mV}$ with respect to the $\mathrm{Ag} / \mathrm{AgCl}$ reference electrode. These conditions were established in both, soluble and immobilised, enzyme sensors.

2.5.1. Soluble enzyme sensor

About $900 \mu \mathrm{L}$ of $50 \mathrm{mM}$ sodium phosphate buffer $\mathrm{pH} 7.6$ (reaction solution) was introduced in the thermostated reaction cell $\left(30^{\circ} \mathrm{C}\right)$. The solution was gently stirred with a magnetic bar up to a stable current was observed and then $10 \mu \mathrm{L}$ of the enzyme solution ( $0.017 \mathrm{U}$ in $50 \mathrm{mM}$ sodium phosphate buffer, $\mathrm{pH} 7.6$ ) was injected, while keeping the stirring for $45 \mathrm{~s}$ more. Then $100 \mu \mathrm{L}$ of standard $\mathrm{Hx}$ or meat extract was injected and the changes in the oxygen consumption were recorded A stable response was observed at 1905 finished. In order to calculate the $\mathrm{Hx}$ co the oxygen accumulation $(\mathrm{mg} / \mathrm{L})$ to this time was taken and extrapolated to its respective calibration curve.

The optimum working conditions were established by analysing of $1 \mathrm{mM} \mathrm{Hx}$ to different temperatures $\left(25,30,35\right.$ and $\left.40^{\circ} \mathrm{C}\right)$ and $\mathrm{pH}$ (5.6, 6.6, 7.6 and 8.6). These optimal conditions were also applied to the immobilised enzyme sensor.

\subsubsection{Immobilised enzyme sensor}

The immobilisation of xanthine oxidase was performed as described Watanabe et al. (1983), Mulchandani et al. (1990) and Luong and Male (1992) with some changes. A mixture (50 $\mu \mathrm{L})$ containing $15 \mu \mathrm{L}$ of $\mathrm{XO}(0.5 \mathrm{U}), 27 \mu \mathrm{L}$ of $50 \mathrm{mM}$ sodium phosphate buffer, $\mathrm{pH} 7.6$ and $8 \mu \mathrm{L}$ of a solution of $12.5 \%$ glutaraldehyde, was layered drop by drop on a immunodyne ABC membrane $\left(1 \mathrm{~cm}^{2}\right)$. The membrane was dried at air for $1 \mathrm{~h}$ in order to initiate the cross-linking and then put inside a $0.1 \mathrm{mM}$ cystein solution for cross-linking and then put inside a $0.1 \mathrm{mM}$ cystein solution for
$20 \mathrm{~min}$ for stabilization. Then, the membrane was washed with so$20 \mathrm{~min}$ for stabilization. Then, the membrane was washed with so-
dium phosphate buffer to eliminate unreacted glutaraldehyde. Once it has dried, $5 \mu \mathrm{L}$ of $2 \%$ cellulose acetate in acetone solution was added to eliminate interferences coming from electrochemical compounds (Nakatani et al., 2005) and to avoid contamination from some forms of inclusion and adsorption of proteins of meat extract (Qiong et al, 1998). Finally, the membrane was left for $5 \mathrm{~min}$ in the air to evaporate the solvent and stored in the sodium phosphate buffer at $4{ }^{\circ} \mathrm{C}$ until use.

The XO membrane was attached onto the Teflon membrane in the oxygen electrode by an o-ring and clamped to the thermostated 
reaction cell. The measurement conditions were similar to those described in the soluble enzyme sensor. About $40 \mu \mathrm{H}$ of standard $\mathrm{Hx}$ or meat extract (adequate dilution with neutralised extraction solution) was injected directly on the XO membrane. After each injection, the XO membrane was washed three times with the sodium phosphate buffer and dried with paper tissue. Before a new injection, 3 min were necessary to restore the equilibrium in the system with the atmospheric oxygen. In this case, the enzymatic rate ( $\mathrm{mg} \mathrm{O}_{2} / \mathrm{L}^{*} \mathrm{~s}^{-1}$ ) value at $10 \mathrm{~s}$ was used and extrapolated espective calibration curve samples. After three consecutive injections of meat samples in both enzyme sensors, a $125 \mathrm{mM} \mathrm{HCl}$ solution was used to avoid fouling problems (Luong \& Male, 1992).

As the xanthine oxidase catalytic activity include not only $\mathrm{Hx}$ but also $\mathrm{X}$, the total obtained signal in the enzyme sensor is represented as the sum of $\mathrm{Hx}$ plus the generated $\mathrm{X}(\mathrm{Hx}+\mathrm{X})$.

\subsection{Standards preparation}

All standard ( $\mathrm{Hx}, \mathrm{X}$ and $\mathrm{UA}$ ) were prepared with the sample extraction solution ( $0.6 \mathrm{M}$ perchloric) neutralised to $\mathrm{pH} 6.5-7$ with solid sodium carbonate and were stored at $-20^{\circ} \mathrm{C}$ until use.

\subsection{Study of the Hx oxidation}

In order to study the $\mathrm{Hx}$ oxidation in the presence of $\mathrm{XO}, 20 \mu \mathrm{L}$ of an $\mathrm{Hx}$ standard solution $(1 \mathrm{mM})$ was injected into the soluble enzyme sensor. During the enzymatic reaction $30 \mu \mathrm{L}$ aliquot was removed each $10 \mathrm{~s}$ and immediately mixed with an equal volume of perchloric acid $(1 \mathrm{M})$ to hold up the reaction. Sample was neutralised by adding $2.25 \mathrm{mg}$ of potassium carbonate to neutralise the solution, centrifuged $\left(10,000 \mathrm{rpm}\right.$ for $5 \mathrm{~min}$ at $\left.4{ }^{\circ} \mathrm{C}\right)$ and analysed by HPLC. The experience was assessed at different temperatures $\left(25,30,35\right.$ and $\left.40{ }^{\circ} \mathrm{C}\right)$.

2.8. Description of the chromatographic method

The $\mathrm{Hx}$ content in meat sample and the $\mathrm{Hx}$ degradation prod ucts ( $\mathrm{X}$ and UA) were determined by HPLC. A $10 \mu$ L of meat extract or $30 \mu \mathrm{L}$ of samples from the enzymatic reaction were injected in C-18 Synergi MAX-RP 4 H $80 \mathrm{~A}, 150 \times 46 \mathrm{~mm}$ (Phenomenex, Torrance, CA, USA) column at $30^{\circ} \mathrm{C}$. A solution of $50 \mathrm{mM}$ potassium phosphate buffer, $\mathrm{pH} 4.0$ was used as mobile phase. The separation conditions were isocratic for $10 \mathrm{~min}$ at a flow rate of $0.8 \mathrm{~mL} / \mathrm{min}$. Then the column was washed with $60 \%$ methanol for $10 \mathrm{~min}$ and equilibrated during $10 \mathrm{~min}$ under initial conditions before each injection. The separated compounds were detected at three wavelengths of $250(\mathrm{Hx}), 270(\mathrm{X})$ and $290(\mathrm{UA}) \mathrm{nm}$ and identified by their respective retention time and spectrum. The quantification was performed by means of respective calibration curves.

\subsection{Assay of validation}

\subsubsection{Linearity}

The linearity in both enzyme sensors, soluble or immobilised, was obtained from the analysis of their respective standards calibration by triplicate applying the least-squares method. Thus, a range of the $\mathrm{Hx}$ standard concentrations $(0-1 \mathrm{mM})$ was correlated with their respective signals obtained in each enzyme sensor.

2.9.2. Repeatability

The measurement of repeatability was tested by repeated injec tions of $1 \mathrm{mM} \mathrm{Hx}$ standard or meat samples which were analysed on the same day with the same equipment under the same conditions in each enzyme sensor. The overall mean concentration and the coefficient of variation (\%) were calculated.
2.9.3. Recovery

Two pork loin samples of seven hours post-mortem were enriched with $0.5,1$ and 1.5 times the naturally $\mathrm{Hx}$ concentration respectively and analysed in the immobilised enzyme sensor for four times. The percentage recovery by comparison with a non-enriched meat sample was calculated for each enriched level.

\subsubsection{Stability}

The stability of xanthine oxidase in both sensors was evaluated. In the soluble enzyme sensor five enzymatic solutions containing $0.017 \mathrm{U}$ of $\mathrm{XO}$ in sodium phosphate buffer $(50 \mathrm{mM}, \mathrm{pH} 7.4)$ were prepared and stored at $4{ }^{\circ} \mathrm{C}$. Each enzymatic solution was tested by week and four successive injections of $20 \mu \mathrm{L}$ of $\mathrm{Hx}(1 \mathrm{mM})$ by day during three days were carried out In the immorilised enzyme day duing the enzyme eprational and storge stability of the XO membrane were evaluated. For the operational stability, successive injections along three days ( 30 analysis per day, approximately) with standard solutions of $\mathrm{Hx}$ were carried out. For the storage stability, six XO membranes were stored at $4{ }^{\circ} \mathrm{C}$ in sodium phosphate buffer $(50 \mathrm{mM}, \mathrm{pH}$ 7.4). Each membrane was tested every fifteen days obtaining its respective calibration curve by duplicate.

2.10. Statistical method

Linear correlation analysis between the $\mathrm{Hx}$ content measured by the enzyme sensor and by HPLC was carried out. The statistical analysis was done using the Statgraphics Plus (v 5.1) software.

\section{Results and discussion}

3.1. Study of the Hx oxidation

The disappearance of $\mathrm{Hx}$, the formation of xanthine and the accumulation of uric acid as products from the oxidative reaction of $\mathrm{Hx}$ were studied by HPLC and the results obtained at $30^{\circ} \mathrm{C}$ shown in Fig. 1. The maximum formation of $\mathrm{X}$ is reached at half of the total $\mathrm{Hx}$ oxidative period (at $30 \mathrm{~s}$ from a total period of $60 \mathrm{~s}$ at $30^{\circ} \mathrm{C}$ ) when there is $33.11 \%$ of $\mathrm{s}$. with respect its initial concentration. This percentage was similar at all the temperatures tested (data not shown) within of $8.48 \%(\mathrm{CV})$. The study of $\mathrm{Hx}$ oxidation is complicated, due to the oxidative degradation of both, $\mathrm{Hx}$ and X occurs simultaneously (Escribano, García-Cánovas, \& GarcíaCarmona, 1988) although the accumulation of $X$ during the enzymatic reaction is a reliable proof that the catalytic affinity of the

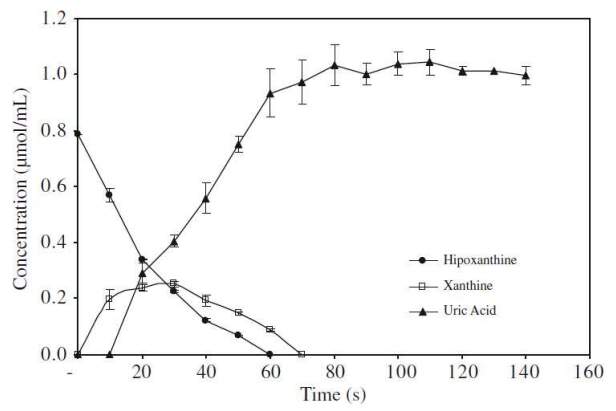

Fig. 1. Evolution of the oxidation reaction of hypoxanthine in the presence of xanthine oxidase at $30^{\circ} \mathrm{C}$ and measured by HPLC. Labelled error bars indicate the standard deviation for each measurement. 
$\mathrm{XO}$ is bigger for $\mathrm{Hx}$ than for $\mathrm{X}$ as already observed (Jezewska, 1973).

In this context, in order to compare the Hx concentration obtained by HPLC with those obtained by the enzyme sensor, which includes the $\mathrm{X}$ response, it was necessary to adjust the data. Consequently, the measurements with the soluble enzyme sensor were adjusted only by subtracting the percentage corresponding to the maximum formation of xanthine (33.11\%). In the case of immobilised enzyme sensor, the results were obtained as the enzymatic lised enzyme sensor, the results were obtained as the enzymatic
rate value at $10 \mathrm{~s}$. The enzymatic rate is due to the action of XO rate value at $10 \mathrm{~s}$. The enzymatic rate is due to the action of $\mathrm{XO}$
on both $\mathrm{Hx}$ plus $\mathrm{X}$ as mentioned before; the relative activity of on both $\mathrm{Hx}$ plus $\mathrm{X}$ as mentioned before; the relative activity of Hx was assigned, as suggested by Yano, Kataho, Watanabe, Nakamconsidering that, the maximum content of $X$ reached at $33.11 \%$ that of $\mathrm{Hx}$, the total enzymatic rate must be re-adjusted by subtracting $16.56 \%$ which would correspond to $\mathrm{X}$, in order to calculate the $\mathrm{Hx}$ concentration.

\subsection{Response of enzyme sensor}

Once the $\mathrm{Hx}$ is injected into the enzyme sensor, a catalytic reaction via xanthine oxidase occurs to produce $\mathrm{X}, \mathrm{H}_{2} \mathrm{O}_{2}$ and $\mathrm{UA}$. The oxygen consumed during the enzymatic oxidation of the $\mathrm{Hx}$ was amperometrically monitored. Thus, the obtained signal decreases in a proportional way to the consumption of oxygen as well as to in a proportional way to the consumption of oxygen as well
the concentration of hypoxanthine (Volpe \& Mascini, 1995).

The optimum working conditions of $\mathrm{pH}$ and temperature in the enzyme sensor were investigated. Nakatani et al. (2005) mentioned that the $\mathrm{pH}$ dependence is due to the level of protonation and it can alter the formation rates and decomposition of the enzyme-substrate complex. In this case, the influence of $\mathrm{pH}$ in the reaction solution was evaluated in the range 5.6-8.6 finding $\mathrm{pH}$ 7.6 as the optimum, while bigger or lower values decreased the enzymatic activity

On the other hand, the reaction rate of the enzyme sensor increased with the temperature up to $35^{\circ} \mathrm{C}$. This result was confirmed by evaluating the disappearance of $\mathrm{Hx}$ during its oxidation at different temperatures $\left(25,30,35\right.$ and $40^{\circ} \mathrm{C}$ ) by HPLC (data not shown). It was found that $30^{\circ} \mathrm{C}$ gave the best response during the enzyme reaction. Further, higher temperatures decrease during the enzyme reaction. Further, higher temperatures decrease
both the level of oxygen in the solvent reaction and the XO stability (Karube et al., 1984).

\subsection{Assay of validation}

The linear relationships between the selected concentration range of $\mathrm{Hx}$ and the enzyme sensor response, as oxygen consumption or enzyme rate in the soluble or immobilised enzyme sensor, tion or enzyme rate in the soluble or immobilised enzyme sensor,
respectively, are shown in Table 1 . The lineal range in the immobi-

Table 1
Validation results for both enzyme sensors.

\begin{tabular}{lll}
\hline Parameter $^{\mathrm{a}}$ & Enzyme sensor \\
\cline { 2 - 3 } & Soluble enzyme & Immobilised enzyme \\
\hline Linear range & $\begin{array}{l}8.68-26.05 \\
\left(R^{2}=0.992\right)\end{array}$ & $15.63-127.00\left(R^{2}=0.995\right)$ \\
Repeatability $(\mathrm{CV} \%)(n=7)$ & \\
Standard & 2.29 & 2.24 \\
Meat sample & 4.81 & 5.04 \\
Stability & & $\begin{array}{l}\text { Up to } 30 \text { successive injections at } \\
30^{\circ} \mathrm{C} \text { and } \\
\text { up to } 2 \text { month in storage at } 40^{\circ} \mathrm{C} \\
\end{array}$ \\
$\begin{array}{lll}\text { Correlations with } \\
\text { HPLC }\left(R^{2}\right)\end{array}$ & 0.9256
\end{tabular}

${ }^{a}$ All parameters in both methods were established by using xanthine oxidas recently prepared or XO membrane at initial condition. lised sensor is wider than in the soluble enzyme; although the inferior limit is lower in this last case. In the immobilised enzyme sensor, the sample is directly applied on the XO immobilised membrane, and the solvent sample (neutralised perchloric acid) generates an electric signal even in the absence of enzyme (data not shown), which explains the residual response. In the soluble enzyme sensor the signal of solvent sample is minimised by dilution into the reaction solution.

The obtained repeatability (CV) in standards and meat samples demonstrated very good results in both enzyme sensors (Table 1). As expected, meat extract results showed higher variability probably due to fouling problems.

The efficacy of the analysis in the immobilised enzyme sensor was evaluated by calculating the recovery after three added levels of $\mathrm{Hx}$ to a meat extract. The recovery data were in the range 99.5$105.2 \%$, as shown in Table 2 .

The sensitivity of detection in both sensors can be also affected by the own $\mathrm{Hx}$ concentration found in the samples. For this reason

Table 2

Recovery of $\mathrm{Hx}$ in pork samples using the immobilised enzyme senser.

\begin{tabular}{llllll}
\hline \multirow{2}{*}{$\begin{array}{l}\text { Added } \\
\text { level }\end{array}$} & \multicolumn{2}{l}{ Hypoxanthine $(\mu \mathrm{mol} / \mathrm{L})^{\mathrm{a}}$} & $\begin{array}{l}\text { Recovery } \\
\text { (\%) }\end{array}$ \\
\cline { 2 - 5 } & $\begin{array}{l}\text { Pork } \\
\text { sample }\end{array}$ & Added & $\begin{array}{l}\text { Theoretical } \\
\text { value }\end{array}$ & Recovered & \\
\hline 0.50 & 46.98 & 23.41 & 70.39 & 74.04 & 105.2 \\
1.00 & 46.98 & 46.81 & 93.79 & 97.86 & 104.3 \\
1.50 & 46.98 & 71.23 & 118.22 & 117.65 & 99.5 \\
\hline
\end{tabular}

a Each value corresponds to four replicates at each concentration level,

b Seven hours post-mortem pork meat.

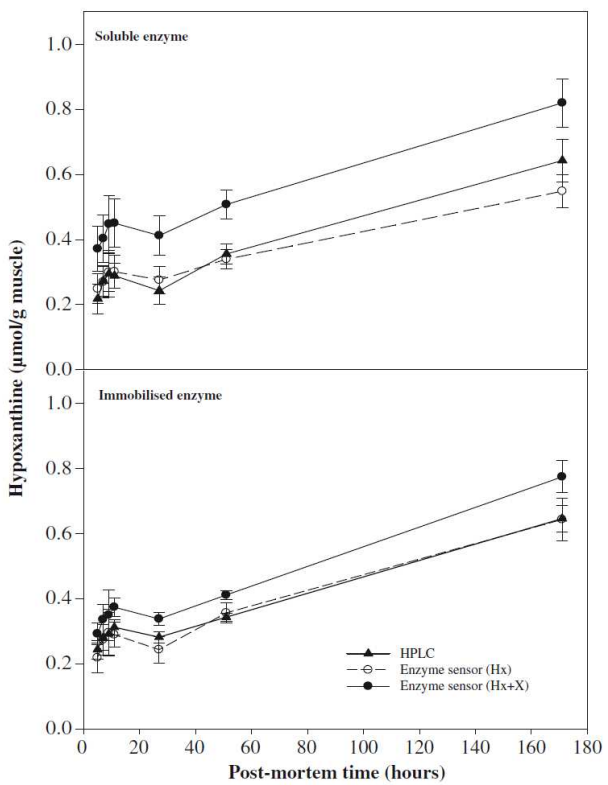

Fig. 2. Evolution of hypoxanthine contents during the ageing process in pork meat measured by the soluble and immobilised enzyme sensors and by HPLC. Labelled error bars indicate the standard error for each measurement. 

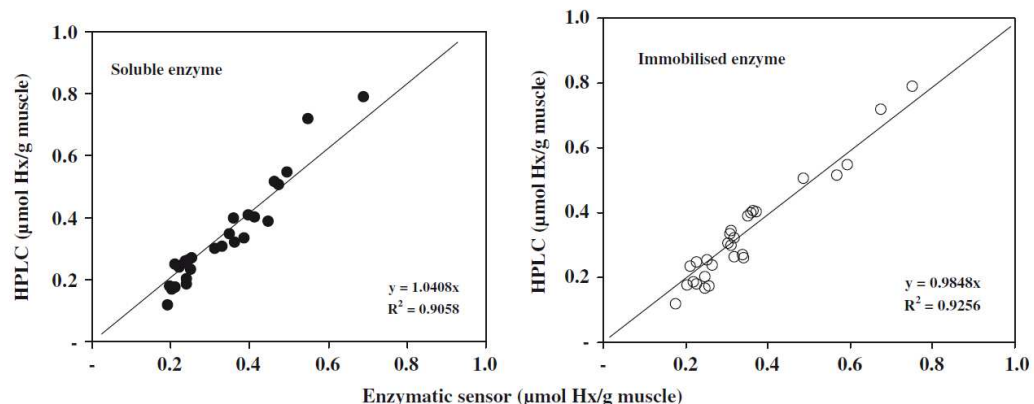
Fig. 3. Correlat
mortem times.

it is necessary to dilute the meat sample appropriately to fit the linear detection range of the enzyme sensor and to obtain a good quantification of $\mathrm{Hx}$. High concentrations of $\mathrm{Hx}$ can inhibit the enzyme by excess of substrate or product or by competition between the $\mathrm{Hx}$ and $\mathrm{X}$ by the active sites of the enzyme (Jezewska, 1973). Readings greater than $1 \mathrm{mg} / \mathrm{L}$ of consumed oxygen or enzyme rate of $0.064 \mathrm{mg} / \mathrm{L}^{*} \mathrm{~s}^{-1}$ during the enzymatic reaction suggest an excess of $\mathrm{Hx}$. Therefore the sample must be diluted. Further in the case of the immobilised enzyme sensor the accuracy of the measurement depends on the fouling level by the direct injection of meat samples. Meanwhile in the case of soluble enzyme sensor it depends more on the concentration of atmospheric oxygen present in the reaction solution, whose concentration can reduce or increase the accuracy of the sensor (Prodromidis \& Karayannis, 2002).

The stability of XO showed excellent results in both enzyme sensors. The soluble sensor showed no significant differences $(p \leqslant 0.05)$ between enzymatic solutions used during five consecutive weeks. The operational stability of XO membrane was constant for the first 30 injections. Subsequently, the sensitivity gradually decreased over 50 and 70 injections with losses of activity of $27.97 \%$ and $55.44 \%$, respectively. Even in these conditions, the XO membrane could be reused obtaining good result with adequate recalibration. The storage stability of $x 0$ membrane was evaluated itive calibration curve. The signal in the enzymatic sensor was stable over a period of two months (within $13.39 \%$, CV) and then it started to decrease at about $38.17 \%$ after three months.

3.4. Application of the enzyme sensor to pork meat samples

In order to evaluate the usefulness of enzyme sensor to determinate the Hx content as an index of meat freshness, pork meat extracts at different post-mortem times ( $5,7,9,11,27,51$ and $171 \mathrm{~h})$ were assessed. The response data with and without adjustment from both enzyme sensors and the data obtained by HPLC are shown in Fig. 2. In general, the formation of $\mathrm{Hx}$ increases with time, reaching a maximum concentration of $0.643 \mu \mathrm{mol} / \mathrm{g}$ muscle at $171 \mathrm{~h}$ post-mortem. Similar results were reported by Batlle et al. (2001), who had already proposed the determination of $\mathrm{Hx}$ as an indicator of ageing in pork meat. The signal $(\mathrm{Hx}+\mathrm{X})$ in the soluble enzyme sensor was higher than in the immobilised enzyme sensor. nevertheless the calculated Hx content in both sensors after applying their respective adjustment factors, did not show significant differences in relation to the HPLC values $(p \leqslant 0.05)$. Therefore, these results indicate that both enzyme sensors are useful for the determination of $\mathrm{Hx}$ in pork meat samples.

The correlation between the $\mathrm{Hx}$ data obtained by the enzyme sensors, soluble and immobilised enzyme, and those obtained by HPLC in the meat samples are shown in Fig 3. In both cases there was a good agreement being the $R^{2}$ coefficients 0.906 and 0.926 , respectively. This suggests that the correction factor applied in each method was correct to estimate the $\mathrm{Hx}$ content in meat samples.

\section{Conclusion}

The obtained results have demonstrated that the proposed enzyme sensors constitute an excellent alternative for the determination of hypoxanthine in pork meat samples. The soluble or immobilised enzyme sensors showed a good sensitivity for the detection of $\mathrm{Hx}$ in comparison with those obtained by HPLC. Adjustment factors due to the $\mathrm{Hx}$ oxidative reaction characteristics were proposed and validated. Furthermore, the easy preparation and operation of both enzyme sensors suggests them as a reliable, rapid and economical alternative for simple or multiple $\mathrm{Hx}$ measurements in short time. Other sensor are more complex because streme there are based on the measurement of hydrogen peroxide and
these require a positive potential and the use of mediator and or other enzymes (like peroxidase) to avoid interferences. Therefore, this methodology may be useful for assessing the progress of ageing in pork meat and thus it can be used for quality control of meat freshness.

\section{Acknowledgements}

Grand from Agroalimed (Consellería de Agricultura, Pesca y Alimentación, Generalitat Valenciana), MEC (Project AGL 200765379-CO2-01) and FEDER funds are acknowledged for their support in this research. The scholarship from the Consejo Nacional de Ciencia y Tecnologia (CONACYT) and Colegio de Postgraduados of Mexico to the doctoral program to A.S. Hernández Cázares is also acknowledged.

\section{References}

Agüi, L., Manso, J., Yáñez-Sedeño, P., \& Pingarrón, J. M. (2006). Amperometric bisensor for hypoxanthine based on immobilized xanthine oxidase on $272-280$.

Batlle, N., Aristoy, M. C.. \& Toldrá, F. (2000). Early post-mortem detection of exudative pork meat based on nucleotide content. Journal of Food Science, 65(3),

413-416.
Batlle, N., Aristoy, M. C., \& Toldrá, F. (2001). ATP metabolites during aging of exudative and nonexudative pork meats. Joumal of Food Science, 66 (1). 68-71. 
Burns, B. G., \& Ke, P. J. (1985). Liquid-chromatographic determination of hypoxanthine content in fish

Carsol, M. A. \& Mascini, M. (1998) Development of a s for the determination of fish freshness. Talanta, 47, 335-342

taneo, P., Pagliaro, V., \& Cantoni, C. (1979). Hypoxanthine and the freshness of meat. Industri Almmentari, 18(3), 222-226.

A. J., \& Pingarrón M. J. (1998) Development of a composite electrode for the determination of hypoxanthine in fish. Analyst, 123(2), 371-377.

Dornelles, M. L. \& Tatsuo, K. L (2002). Review of the use of biosensors as analytical tools in the food and drink industries. Food Chemistry, 77, 237-256.

Jadevych, S. V., Arkhypova, V. N., Soldatkin, A. P.., Elskaya, A. V., Martelet, C., \& Jaffrezic-Renault, N. (2008). Amperometric enzyme biosensors: Past, present

\& García-Carmona, F. (1988). A kinetic study of

829-833.
Fujita, T., Hori, Y., Otani, T., Kunita, Y., Sawa, S., Sakai, S., et al. (1998). Applicability of the Ko value as an index of freshness for porcine and chicken muscles. Agricultural and Biological Chemistry, 52(1), 107-112

政 $53,58-6$

Hu, S., Xu, C., Luo, J., Luo, J., \& Cui, D. (2000). Biosensor for detection of hypoxanthine based on xanthine oxidase immobilized on chemically modified carbon paste electrode. Analytica Chimica Acta, 412, 55-61.

Characterization and meat freshness application of a serial three-enzyme reactor system measuring ATP-degradative compounds. Analytica Chimica Acta, 404, 75-81.

Jezewska, M. M. (1973). Xanthine accumulation during hypoxanthine oxidation by milk xanthine oxidase. European Journal of Biochemistry, 36, 385-390.

ube, l., Matsuoka, M., Suzuki, S., Watanabe, E., \& Toyoma, K. (1984). r system. Journal Agricultural Food Chemical, 32, 314-319.

determination of the hypoxanthine ratio, an ind a new biosensor system for the and Microbial Technology, 14, 125-130. wong, J. H. T., Bouvrette, P., \& Male, K. B. (1997). Developments and applications of biosensor in food analysis. Tibtech, 15, 369-376.

(a) $215-222$

Mulchandani, A. Male, K. B., \& Luong, I. H. T. (1990). Development of a biosensor for assaying post-mortem nucleotide degradation in fish tissues. Biotechnology and
Bioengineering, 35, 739-745.
Nakatani, H. S., Dos Santos, L. V., Peralta, P., Marqués, G. S., Matsushita, M., de Souza, tivensor based on xanthine oxidase for monitorin ypoxame in fish meat American Journal of Biochemisty

Nanjyo, Y., \& Yao, T. (2002). Rapid measurement of fish freshness indices by an amperometric flow-injection system with a 16-way switching valve an immobilized enzyme feactors. Analy yica Chin a

guyen, A. L., Luong, J. H. T., \& Yacynych, A. M. (1991). Retention of enzyme by electropolymerized film: A new approach in develo
biosensor Biotechnology and Bioengineering, 37, 729-735.

Numata, M., Funazaki, N., Ito, S., Asano, Y. \& Yano, Y. (1996). Flow-injection analysis for hypoxanthine in meat with dissolved oxygen detector and enzyme reactor Talanta, 43, 2053-2059.

okuma, H., Takahashi, H., Yasawa, S., \& Sekimukai, S. (1992). Development of Analytica Chimica Acta, 260, 93-98.
Anster kuma, H., \& Watanabe, E. (2002). Flow system for fish freshness determination based on double multi-enzyme reactor electrodes. Biosensors and Bioelectronic, $17,367-372$.

rodromidis, M. L.. \& Karayannis, M. L. (2002). Enzyme based amperometric biosensors for food analysis. Flectroanalysis, 14(4), 241-261.

(a) asai, R., Cassens, R. G., Briskey, E. J., \& Greaser, M. L. (1972). Studies on nucleotid metabolism in porcine Longissimus muscle post-mortem. Journal of Food Science, $37,612-616$. . Boca Raton, FL: CRC olpe, G., \& Mascini, M. (1995). Enzyme sensors for determination of fish freshness.

Talanta, 43, 283-289.
Venugopal, V. (2002). Biosensor in fish production and quality control. Biosensor and Bioelectronics, 17, 147-157

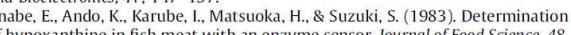
$496-500$

scheffler, T. L., \& Gerrard, D. E. (2007). Mechanisms controlling pork meat quality development: The biochemistry controlling post-mortem energy metabolism.

, L. Yang, L, \& Peng, T. (1996). Amperometric determination of fish freshness 298-302.

Yano, Y., Kataho, N., Watanabe, M., Nakamura, T., \& Asano, Y. (1995). Evaluation or beef aging by determination of hypoxanthine and xanthine contents: Application of a xanthine sensor. Food Chemistry, 52(4), 439-445. 


\section{Anexo B}

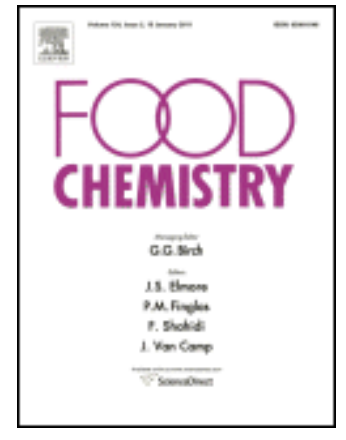

Hydrophilic interaction chromatographic determination of adenosine triphosphate and its metabolites

Leticia Mora, Aleida S. Hernández-Cázares, María-Concepción Aristoy, Fidel Toldrá

Food Chemistry, 123 (2010) 1282-1288 

Analytical Methods

Hydrophilic interaction chromatographic determination of adenosine triphosphate and its metabolites

Leticia Mora, Aleida S. Hernández-Cázares, María-Concepción Aristoy, Fidel Toldrá *

Instituto de Agroquímica y Tecnología de Alimentos (CSIC), P.O. Box 73, 46100 Burjassot, Valencia, Spain

A R T I C L E I N F O

Article history:

eceived 70 tober 2008

Received in revised form 27 April 2010

Accepted 13 May 2010

Keywords:

Hydrophilic interaction chromatography

HILIC

ATP

$\mathrm{ADP}$

AMP

Hypoxanthin

Inosine
Meat
A B S T R A C T

A new HPLC method based on hydrophilic interaction chromatography (HILIC) has been developed for the simultaneous analysis of adenosine triphosphate (ATP), adenosine diphosphate (ADP), adenosine monophosphate (AMP), inosine monophosphate (IMP), inosine (Ino), hypoxanthine (Hx) and nicotinamide adenine dinucleotide $\left(\mathrm{NAD}^{+}\right)$in pork loin muscle. The chromatographic analysis has been developed using zwitterionic polymeric column and it has been optimised in terms of linearity, repeatability, reproduc ibility and recovery. Detection limit values of $0.10,0.15,0.05,0.16,0.16,1.72$ and $0.15 \mu \mathrm{g} / \mathrm{mL}$ for ATP, ADP, AMP, IMP, Ino, HX and NAD respectively were achieved. A comparison between the pork meat concentrations of the compounds analysed by hydrophilic interaction chromatography (HILIC), using a ZIC ${ }^{\infty}$ $p$ HILIC column, and ion-pair reversed-phase chromatography (IP-RP-HPLC), using a Zorbax Eclipse XDBC18 column, has been done, concluding that the new chromatographic methodology constitutes a valid and reliable alternative to the existing methods. Finally, this method has also proved to be very effective in the isolation of guanosine, guanosine monophosphate (GMP), guanosine diphosp hate (GDP), guanosine triphosphate (GTP), creatinine ( $\mathrm{Cn}$ ) and uric acid (UA) from a standards mixture.

(Q) 2010 Elsevier Ltd. All rights reserved.

\section{Introduction}

Post-mortem muscle reactions involve a serial of biochemical and physical changes resulting in the conversion of muscle to meat. These reactions start by stopping the adenosine triphosphate (ATP) generation, which is absolutely essential to keep the muscle in a relaxed state. Then, a replenishment of ATP by the creatine kinase and myokinase-catalysed reactions occurs, but once $70 \%$ of the phosphocreatine $(\mathrm{PCr})$ has been degraded, ATP levels rapidly decreased and by anaerobic glycolysis to rephosphorylate adenosine diphosphate (ADP) to ATP starts, producing lactate and $\mathrm{H}^{+}$ that are accumulated in muscle resulting in a $\mathrm{pH}$ decrease. This breakdown of ATP results in an increasing of muscle tension known as rigor mortis. Thus, after death ATP is rapidly splitted into (ADP and subsequently into adenosine monophosphate (AMP) and inosine monophosphate (IMP). This compound is further degraded to inosine (Ino) and hypoxanthine (Hx) (Saito, Araki, \& Matsuyoshi, 1959).

Many authors have described a correlation between some of these metabolites and freshness in some fish species (Hattula \& Kiesvaara, 1996; Jones, Murray, Livingst, \& Murray, 1964; Luong \& Male, 1992), as well as with meat ageing and quality

\footnotetext{
* Corresponding author. Tel.: + 34 3900022x2112; fax: +34 3636301 E-mail address: ftoldra@iata.csic.es (F. Toldrá.
}

0308-8146/\$ - see front matter $\odot 2010$ Elsevier Ltd. All rights reserved. doi:10.1016/j.foodchem.2010.05.072
Batlle, Aristoy, \& Toldrá, 2001; Fujita et al., 1988; Yano, Kataho Watanabe, Nakamura, \& Asano, 1995). Thus, in view of the importance of nucleotides and their derivates in the energetic metabolism and their interest in the quality assessment, many studies have been focused during the last decades on the development of different techniques to separate, characterise and quantify these compounds (Aristoy \& Toldrá, 2009). Several methods have been used to measure ATP and its related compounds, including nuclear magnetic resonance spectroscopy (NMR) (Gariod et al., 1994; Van den Thillart, Van Waarde, Muller, Erkelens, \& Lugtenburg, 1990), capillary electrophoresis (CE) (Nguyen, Luong, \& Masson, 1990; Soga \& Imaizumi, 2001), radioimmunoassay (Roberts, Morris, \& Clifford, 1991), thin-layer chromatography (TLC) (Dingle, Hines, \& Fraser 1968) and enzymatic assays (Luong \& Male, 1992 . 1995). However, versatility, short analysis time and high resolution have made high performance liquid chromatography (HPLC) the most widely used technique for the analysis of nucleotides and nucleosides in biological samples. Thus, reversed-phase high performance liquid chromatography (RP-HPLC) with (Meynial, Paquet, \& Combes, 1995; Murray \& Thomson, 1983; Veciana-Nogues, Izquierdo-Pulido, \& Vidal-Carou, 1997) and without ion-pair (Kuda, zquie, Coto, Yan, 2007; Veciand-Nogues a a 1997) (Kuda, Fujita, Goto, \& Yano, 2007; Veciana-Nogues et al., 1997) and ionexchange HPLC (Gao et al., 2006; Lamb \& Ye, 1992) have been
the method of choice for the isolation of these compounds during decades. 
Although these techniques are very powerful, hydrophilic interaction chromatography (HILIC) could constitute an interesting alternative for the separation of such compounds (Alpert, 1990; Yoshida, 2004). This technique uses mobile phase compositions comparable to those employed in RP-HPLC with the consequent advantage in the solubility of the analyte and the no necessity of ion-pair and derivatisation reagents. It is also well known that ion pair reagents used in reversed-phase chromatography as well as salts in ion-exchange chromatography can cause signal suppression (Oertel, Neumeister, \& Kirch, 2004; Strege, 1998). Thus, HILIC is an interesting method compatible with further mass spectrometry analysis, where no ion pairing and only a low amount of volatile salt can be used, avoiding previous desalting steps.

The objective of the present study was to develop a new method based on HILIC for the simultaneous analysis of ATP, ADP, AMP, IMP, Ino, $\mathrm{Hx}$ and the nicotinamide adenine dinucleotide $\left(\mathrm{NAD}^{+}\right)$ in meat. HILIC method was optimised and levels of these compounds measured in pork loin samples at different post-mortem pounds measured in pork loin samples at different post-mortem
time $(5,7,9,11,27,51$ and $171 \mathrm{~h}$ ) were compared with those obtime ( $5,7,9,11,27,51$ and $171 \mathrm{~h}$ ) were compared with those ob-
tained by ion-pair reversed-phase chromatographic (IP-RP-HPLC) analysis. Finally, other analytes also related to the energetic metabolism of muscle such as creatinine $(\mathrm{Cn})$, uric acid (UA), guanosine (GUA), guanosine monophosphate (GMP), guanosine diphosphate (GDP) and guanosine triphosphate (GTP) were also separated in a the same chromatographic method.

\section{Materials and methods}

2.1. Chemicals and reagents

All chemical and chromatographic reagents used were of HPLC grade. Acetonitrile (ACN), methanol, ammonium acetate, glacial acetic acid, perchloric acid and potassium carbonate were purchased from Scharlau (Barcelona, Spain). Potassium dihydrogen orthophosphate and potassium hydroxide were from Panreac (Barcelona, Spain) and PIC (t) (tetrabutylammonium hydrogen sulphate/ (Waters $\mathrm{Co}$ Milford, MA). All standards were from Sigma (St. Louis, MO).

\subsection{Materials and instrumentation}

Pork Longissimus dorsi muscles were excised from five carcasses of 4-month-old pigs and immediately chilled at $4{ }^{\circ} \mathrm{C}$ until sampled. Only normal muscles were selected in order to avoid the variability Only normal muscles were selected in order to avoid the variability
in nucleotides content in dark, firm and dry (DFD) and pale, soft in nucleotides content in dark, firm and dry (DFD) and pale, soft
and exudative (PSE) muscles (Batlle, Aristoy, \& Toldrá, 2000; Batlle and exudative
et al., 2001)

Chromatography was performed in a HPLC Agilent 1100 series system (Agilent Technologies, Palo Alto, $\mathrm{CA}$ ) equipped with a quaternary pump (G1311A) an autosampler (G13131A) a thermostated column compartment (G1316A) and a vacuum degasser (G1379A). Ultraviolet detection was made by a G1315B diode array detector, which was used in the range of $195-300 \mathrm{~nm}$.

\subsection{Sample preparation}

Less than $1 \mathrm{~mm}$ thick slices were excised from pork $L$. dorsi muscles at $5 \mathrm{~h}$ post-mortem and immediately immersed in liquid nitrogen to assure the complete freezing of the slices and their nitrogen to assure the complete freezing of the slices and their
enzymatic inactivation. Samples of these $L$. dorsi muscles were also enzymatic inactivation. Samples of these $L$. dorsi muscles were also
taken at $7,9,11,27,51$ and $171 \mathrm{~h}$ and processed in the same way to those obtained at $5 \mathrm{~h}$ post-moitem.

Samples were extracted and deproteinised following the method described by (Burns \& Ke, 1985) with some minor changes.
Briefly, $4 \mathrm{~g}$ of frozen tissue were minced and homogenised with $15 \mathrm{~mL}$ of cold $0.6 \mathrm{M}$ perchloric acid for $4 \mathrm{~min}$ at $4{ }^{\circ} \mathrm{C}$ in a stomacher (Seward Laboratory) and further centrifuged at $24,500 \mathrm{G}$-force for $20 \mathrm{~min}$ in the cold $\left(4^{\circ} \mathrm{C}\right)$. Supernatant was filtered through glass wool and $12 \mathrm{~mL}$ of this solution were neutralised (pH 6.5-7) by adding solid potassium carbonate, standing in an ice bath for $5 \mathrm{~min}$. Finally, the sample was centrifuged as described above for $10 \mathrm{~min}$ and the supernatant was stored under vacuum at $-20^{\circ} \mathrm{C}$ $10 \mathrm{~min}$ and

Samples to be analysed by IP-RP-HPLC were thawed and directly injected in the HPLC system whereas samples to be analysed by HILIC were thawed and deproteinised with one volume of ACN and centrifuged at $4{ }^{\circ} \mathrm{C}$ for $10 \mathrm{~min}(24,500 \mathrm{G}$-force). The addition of an organic solvent like acetonitrile in the sample was necessary in HILIC conditions in order to decrease the polarity of the solvent and thus, improve the shape of the peak.

\subsection{Standards preparation}

Stock solutions of all standards were prepared employing the solvent sample solution, which is $0.6 \mathrm{M}$ perchloric acid previously neutralised to $\mathrm{pH}$ 6.5-7 with potassium carbonate.

Working standard solutions for the IP-RP-HPLC analysis were prepared over the appropriate concentration range by dilution of stock solutions with the neutralised perchloric acid solution, whereas those working standard solutions for the HIUC chrom tography were prep tography were prepared by dil volume of ACN and thus consecutive dilutions with a neutralised
$0.6 \mathrm{M}$ perchloric acid:ACN $(50: 50, \mathrm{v} / \mathrm{v})$ solution. All stock solutions were stored at $-20^{\circ} \mathrm{C}$ until use.

\subsection{Description of the chromatographic methods}

The HILIC separation was performed using a ZIC ${ }^{\text {De }}$ - HILIC column $(4.6 \times 150 \mathrm{~mm}, 5 \mu \mathrm{m})$ together with a $\mathrm{ZIC}^{\circledR}$ - $p$ HILIC guard column $(2.1 \times 20 \mathrm{~mm}, 5 \mu \mathrm{m})$ both from SeQuant (Sweden). Twenty microliters of each sample were injected into the HPLC system and the separation conditions that are described in Table 1 were and the separation conditions that are described in Table 1 were
developed at $28^{\circ} \mathrm{C}$ and at a flow rate of $0.5 \mathrm{~mL} / \mathrm{min}$. The column developed at $28^{\circ} \mathrm{C}$ and at a flow rate of $0.5 \mathrm{~mL} / \mathrm{min}$. The column
was equilibrated for $15 \mathrm{~min}$ under initial conditions before each was equilibr.

injection.
The HILIC method has been compared to an IP-RP-HPLC method previously described by several authors (Batlle et al., 2001; Veciana-Nogues et al., 1997) with some minor changes. Ten microliters of sample were injected in a Zorbax Eclipse XDB-C18 column $(4.6 \times 150 \mathrm{~m}$ (Palo Alto, CA). Mobile phases consisted of solvent $\mathrm{A}$, containing $5 \mathrm{mM}$ PIC ${ }^{\circledR}$ in $100 \mathrm{mM}$ phosphate buffer at $\mathrm{pH} 6$ and solvent B, containing $75 \%$ of solvent $A$ and $25 \%$ of methanol. The separation conditions were an isocratic of $5 \mathrm{~min}$ of solvent $\mathrm{A}$ followed by a linear gradient to $100 \%$ of solvent $\mathrm{B}$ in $18 \mathrm{~min}$ at a flow rate of $1 \mathrm{mg} / \mathrm{mL}$ and $30^{\circ} \mathrm{C}$.

Table 1

Chromatographic conditions of the HILIC method.

\begin{tabular}{|c|c|c|c|c|}
\hline \multirow[t]{2}{*}{ Time ( $\mathrm{min})$} & \multicolumn{4}{|c|}{ Solvent ${ }^{\mathrm{a}}$} \\
\hline & A & B & $\mathrm{C}$ & D \\
\hline 0 & 15 & 0 & 80 & 5 \\
\hline 3 & 0 & 25 & 70 & 5 \\
\hline 15 & 0 & 25 & 70 & 5 \\
\hline 25 & 0 & 50 & 40 & 10 \\
\hline 35 & 0 & 50 & 40 & 10 \\
\hline
\end{tabular}

ZIC - pHILIC column $(4.6 \times 150 \mathrm{~mm}, 5 \mathrm{~mm})$; flow rate: $0.5 \mathrm{~mL} / \mathrm{min} ; 28^{\circ} \mathrm{C}$. Solvent A: ammonium acetate 150 
The column was equilibrated with $100 \%$ of solvent $A$ for 15 min before each injection.

All samples and solvents were filtered through a $0.22 \mu \mathrm{m}$ nylon membrane filter. Solvents were also degassed prior to the analytical run. Separations were monitored using a diode array detector at a wavelength of $254 \mathrm{~nm}$.

2.6. Assay validation

2.6.1. Linearity

Linearity of the method has been assessed using three calibration curves per analyte constructed correlating the corresponding peak areas $(\mathrm{mAU} * \mathrm{~s})$ against the concentration of the analyte. Each calibration curve was calculated using peak areas at six standard concentrations which range was selected based on the expected concentration of analyte in the pork meat samples.

2.6.2. Detection limits $(L D)$

The LD for each compound was set as a signal-to-noise ratio of 3:1. The background noise at the retention time area for each compound was calculated by taking the average signal of 20 blank solutions and the LD values obtained were confirmed analysing increasing dilutions of $5 \mathrm{~h}$ post-mortem pork meat samples.

\subsubsection{Repeatability}

In the repeatability study, eight samples from a $5 \mathrm{~h}$ post-mortem pork meat were processed to estimate the mean concentrations of each analyte. The different measurements were done consecutively by the same analyst under the same conditions.

2.6.4. Reproducibility

Reproducibility of the method was tested by analysing, on six different days, a pork meat sample which was extracted and stored in eight aliquots at $-20{ }^{\circ} \mathrm{C}$ awaiting further sample preparation and chromatographic analysis. Thus, each analysis was taken on identical animal samples but under different conditions (different operators and HPLC system, different times and days).

2.6.5. Recovery

Recovery data of all seven compounds were determined by adding known amounts of standards to $5 \mathrm{~h}$ post-mortem pork loin samples. Thus, samples were enriched with standard solutions of the different studied compounds to yield concentrations equivalent to $0.5,1$ and 1.5 times the values obtained in the reproducibility studies. At each level, analyses were performed in duplicate and ity studies. At each level, analyses were performed in duplicate and meat sample.

\subsection{Comparison between HILIC and IP-RP-HPLC methods}

The main purpose of this work was to develop an alternative to IP-RP-HPLC method based on HILIC for the simultaneous analysis of ATP, ADP, AMP, IMP, Ino, Hx and NAD ${ }^{+}$in meat. Thus, these compounds were analysed by HILIC and by IP-RP-HPLC in different pounds were analysed by HILIC and by IP-RP-HPLC in different
post-mortem times $(5,7,9,11,27,51$ and $171 \mathrm{~h})$ pork meat samples as previously described.

\subsection{Statistical method}

The ANOVA procedure was used to determine significant differences between HILC and IP-RP-HPLC methodology, using a ZIC ences between HILIC and IP-RP-HPLC methodology, using a ZIC ${ }^{\infty}-$
pHILIC column and a Zorbax Eclipse XDB-C18 column, respectively. Each statistical analysis was done using the software Statgraphics Plus (v 5.1.) analysing five loins from different porks $(n=5)$ and the normality of the data was tested before applying the ANOVA procedure.

\section{Results and discussion}

3.1. Optimisation of the chromatographic method

To establish optimal conditions for the separation of ATP, ADP, AMP, IMP, Ino, Hx and NAD by HILIC, the effect of the organic solvent, salt and $\mathrm{pH}$ was examined.

A higher proportion of organic solvent in the mobile phase increases the retention of the analytes in HILIC analysis. In this way, although many organic solvents can be used in HILIC, ACN use to be the solvent of choice. It provided an acceptable solubility of the studied compounds and higher retention than the stronger methanol, to permit the separation of the early eluting. $\mathrm{Hx}$ and methanol, to permit the separation of the early eluting, $\mathrm{Hx}$ and
Ino (Figs. 1 and 2). Thus, higher ACN amounts were used in the first Ino (Figs. 1 and 2). Thus, higher ACN amounts were used in the first
minutes of the chromatogram, decreasing lately its concentration minutes of the chromatogram, decreasing lately its concentration
to shorten the chromatogram and to improve the peaks shape (see Table 1).

Several salts were investigated to determine the most adequate buffer regarding its solubility in organic solvents and its interaction with the studied compounds. Ammonium acetate was the salt of choice because it provides the best results in selectivity and of choice because it provides the best results in selectivity and
reproducibility, presents excellent solubility even at high concenreproducibility, presents excellent solubility even at high concen-
trations of organic solvents and it is highly volatile, making it suitable for eventually further mass spectrometry analysis.

Salt concentration and $\mathrm{pH}$ have an important effect on retention and selectivity in hydrophilic chromatography by influencing analyte ionisation. Both parameters were optimised in the ammonium acetate mobile phase. In this way, a good separation of the standards of the studied analytes was obtained with $83.3 \mathrm{mM}$ ammonium acetate $\mathrm{pH} 7$, but an interfering peak identified as creatinine $(\mathrm{Cn})$ overlapped with $\mathrm{Hx}$ when analysing pork meat
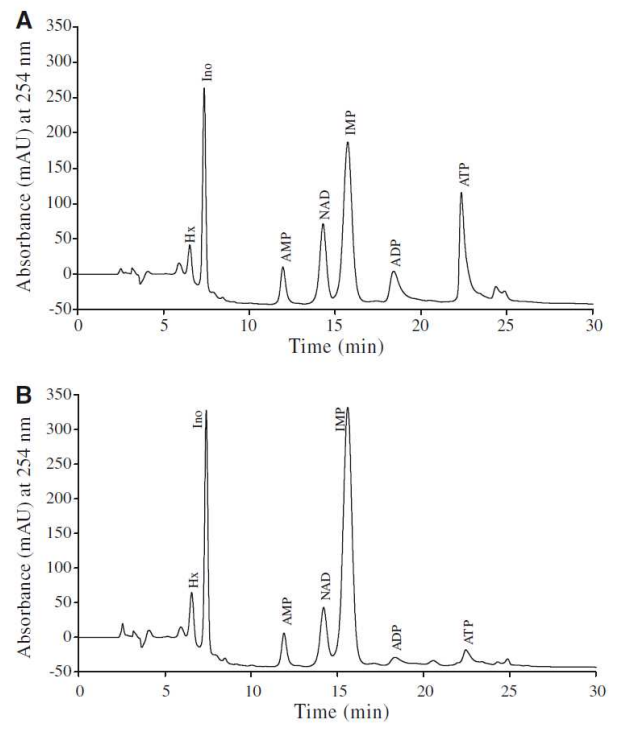

Fig. 1. Chromatograms corresponding to $5 \mathrm{~h}(\mathrm{~A})$ and $27 \mathrm{~h}$ (B) post-mortem pork loin sample analysis. In all cases hypoxanthine $(\mathrm{Hx})$, inosine (Ino), adenosine phosphase (IMP) adenosine diphosphate (ADP) and adenosine triphosphate (ATP) were detected at $254 \mathrm{~nm}$ 


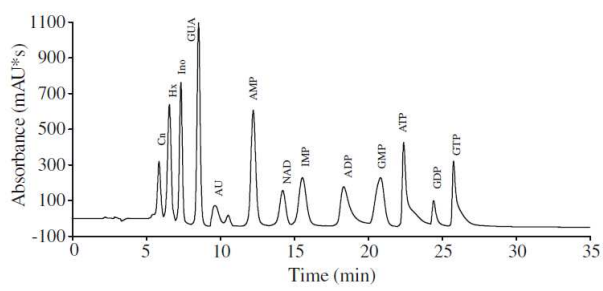

Fig. 2. Chromatogram corresponding to the separation of the standards of the studied analytes together with creatinine (Cn), uric acid (UA), guanosine (GUA),

samples. Different $\mathrm{pH}$ and increasing salt concentrations were tested to separate both compounds, obtaining an acceptable separation at $112.5 \mathrm{mM}$ of ammonium acetate at $\mathrm{pH} 3.5$. Thus, an initial column conditioning at pH 3.5 allowed the separation of $\mathrm{Cn}$ and $\mathrm{Hx}$, without affecting the selectivity and resolution of the rest of the peaks as shown in Fig. 2.

The injection solvent is also a very important parameter because it influences the shape of the peak. A high proportion of water in the injection solvent could result in lower retention, poorer efficiency and a worse separation but, on the other hand, nucleotides can not be easily solubilised in highly organic solutions. An adequate solubilisation, was achieved by using 50\% ACN $/ 50 \%$ neutralised $0.6 \mathrm{M}$ perchloric acid as injection solvent. A good solubilisation of all the studied compounds was also obtained with higher ACN amounts but NAD, ADP and ATP showed low stability in these highly organic solutions.

The final chromatographic conditions described in Table 1 resulted in a good separation of the seven studied compounds as can be observed in Fig. 1A and B. Other metabolites participating in the meat energetic metabolism like Cn, UA, GUA, GMP, GDP and GTP were injected together with the studied compounds and analysed using the HILIC method obtaining a good separation for all of them (Fig. 2). The chromatographic method developed in this study has not been validated for these last mentioned compounds

Table 2

Linearity and analyte retention times obtained in the analysis of nucleotide and nucleoside standards.

\begin{tabular}{|c|c|c|c|c|c|c|c|}
\hline \multirow[t]{2}{*}{ Analyte } & \multirow{2}{*}{$\begin{array}{l}\text { Retention time } \\
(\mathrm{min})\end{array}$} & \multirow{2}{*}{$\begin{array}{l}\text { Range } \\
(\mu \mathrm{g} / \mathrm{mL})\end{array}$} & \multicolumn{2}{|l|}{ Slope } & \multicolumn{3}{|l|}{ Intercept } \\
\hline & & & Mean* & SD & Mean ${ }^{*}$ & SD & $\mathrm{R}^{2}$ \\
\hline $\mathrm{Hx}$ & 6.5 & $0.5-100$ & 158499.54 & 2711.16 & 38.63 & 7.48 & 0.95 \\
\hline INO & 7.3 & $1-150$ & 80276.48 & 337.77 & 49.03 & 47.15 & 0.95 \\
\hline AMP & 11.9 & $2-250$ & 67105.67 & 125.97 & -50.17 & 4.93 & 0.99 \\
\hline NAD & 14.4 & $3-350$ & 31569.24 & 220.54 & 71.85 & 3.26 & 0.99 \\
\hline IMP & 15.8 & $2-250$ & 40889.22 & 251.93 & -51.00 & 10.99 & 0.99 \\
\hline ADP & 18.6 & $2-300$ & 45553.95 & 1002.90 & -394.00 & 210.03 & 0.99 \\
\hline ATP & 22.5 & $3-400$ & 47802.50 & 740.50 & -558.62 & 138.10 & 0.95 \\
\hline
\end{tabular}

Calculated from three calibration lines representing concentration $(\mathrm{mg} / \mathrm{mL})$ vs. area $(\mathrm{mAU} * \mathrm{~s})$. For each analyte eight datapoints were used.

Table 3

\begin{tabular}{|c|c|c|c|c|c|c|c|c|}
\hline \multirow[t]{2}{*}{ Analyte } & \multicolumn{2}{|l|}{$\operatorname{LOD}(N=20)$} & \multicolumn{3}{|l|}{ Repeatability $(N=8)$} & \multicolumn{3}{|c|}{ Reproducibility $(N=6)$} \\
\hline & Mean $(\mu \mathrm{g} / \mathrm{mL})$ & SD & Mean $(\mathrm{mg} / 100 \mathrm{~g})$ & SD & $\mathrm{CV}$ & Mean $(\mathrm{mg} / 100 \mathrm{~g})$ & SD & $\mathrm{cV}$ \\
\hline $\mathrm{Hx}$ & 1.72 & 0.10 & 3.04 & 0.03 & 1.00 & 3.04 & 0.02 & 0.77 \\
\hline Ino & 0.16 & 0.03 & 24.19 & 0.13 & 0.55 & 24.31 & 0.32 & 1.33 \\
\hline AMP & 0.05 & 0.01 & 10.22 & 0.10 & 0.98 & 10.09 & 0.23 & 2.32 \\
\hline NAD & 0.15 & 0.01 & 59.85 & 0.73 & 1.22 & 55.88 & 5.31 & 9.50 \\
\hline IMP & 0.16 & 0.01 & 130.79 & 0.77 & 0.59 & 128.69 & 2.10 & 1.64 \\
\hline ADP & 0.15 & 0.01 & 42.17 & 0.37 & 0.88 & 39.15 & 3.00 & 7.66 \\
\hline ATP & 0.10 & 0.01 & 104.10 & 0.40 & 0.39 & 104.26 & 0.75 & 0.72 \\
\hline
\end{tabular}

Table 4

\begin{tabular}{|c|c|c|c|c|c|}
\hline \multirow[t]{2}{*}{ Analyte } & \multirow[t]{2}{*}{$\begin{array}{l}\text { Pork } \\
\text { loin }^{\mathrm{a}}\end{array}$} & Spike & $\begin{array}{l}\text { Theoretical } \\
\text { value }\end{array}$ & \multirow[t]{2}{*}{ Recovered $^{2}$} & \multirow[t]{2}{*}{$\begin{array}{l}\text { Recovery } \\
\text { (\%) }\end{array}$} \\
\hline & & \multicolumn{2}{|c|}{ ( $\mathrm{mg} / 100 \mathrm{~g}$ of pork loin) } & & \\
\hline \multirow{4}{*}{$\mathrm{Hx}$} & \multirow{4}{*}{3.23} & 2.85 & 6.08 & 6.07 & 99.71 \\
\hline & & 5.70 & 8.93 & 8.67 & 97.05 \\
\hline & & 11.40 & 14.63 & 14.19 & 96.98 \\
\hline & & 11.25 & 35.91 & 35.23 & 98.11 \\
\hline \multirow[t]{3}{*}{ Ino } & \multirow[t]{3}{*}{24.66} & 22.50 & 47.16 & 46.30 & 98.16 \\
\hline & & 45.00 & 69.66 & 69.52 & 99.80 \\
\hline & & 5.21 & 15.83 & 17.60 & 111.20 \\
\hline \multirow[t]{3}{*}{ AMP } & \multirow[t]{3}{*}{10.66} & 10.42 & 21.04 & 24.36 & 115.79 \\
\hline & & 20.85 & 31.46 & 38.26 & 121.60 \\
\hline & & 10.80 & 54.55 & 61.98 & 113.62 \\
\hline \multirow[t]{3}{*}{ NAD } & \multirow[t]{3}{*}{43.94} & 21.60 & 65.35 & 69.20 & 105.88 \\
\hline & & 43.20 & 86.95 & 84.49 & 97.16 \\
\hline & & 58.50 & 192.15 & 189.81 & 98.78 \\
\hline \multirow{3}{*}{ IMP } & \multirow{3}{*}{133.65} & 117.00 & 250.65 & 248.36 & 99.09 \\
\hline & & 234.00 & 367.65 & 371.58 & 101.07 \\
\hline & & 22.50 & 72.57 & 70.79 & 97.54 \\
\hline \multirow{3}{*}{ ADP } & \multirow{3}{*}{50.07} & 45.00 & 95.07 & 97.83 & 102.89 \\
\hline & & 90.00 & 140.07 & 145.01 & 103.52 \\
\hline & & 62.55 & 166.44 & 158.58 & 95.28 \\
\hline \multirow[t]{2}{*}{ ATP } & \multirow[t]{2}{*}{103.89} & 125.10 & 228.99 & 217.09 & 94.80 \\
\hline & & 250.20 & 354.09 & 341.43 & 96.43 \\
\hline
\end{tabular}

a Each value corresponds to three replicates at each concentration level.

because their presence in fresh meat is rather poor (Batlle et al., 2000). However, the amount of Cn, UA, GUA, GMP, GDP and GTP in dry-cured, fermented and cooked meat products is higher and the importance of some of these compounds as Cn or GTP in meat flavour perception has been widely studied (Cambero, Pereira1970).

\subsection{Assay validation}

Calibration curves were built by using different ranges according to the concentration of each analyte in the meat samples. Plots and respective regression coefficient of the studied analytes are shown in Table 2. The response was linear for all the analytes
shold respective regression coeficient of the studied anates are

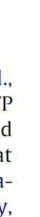



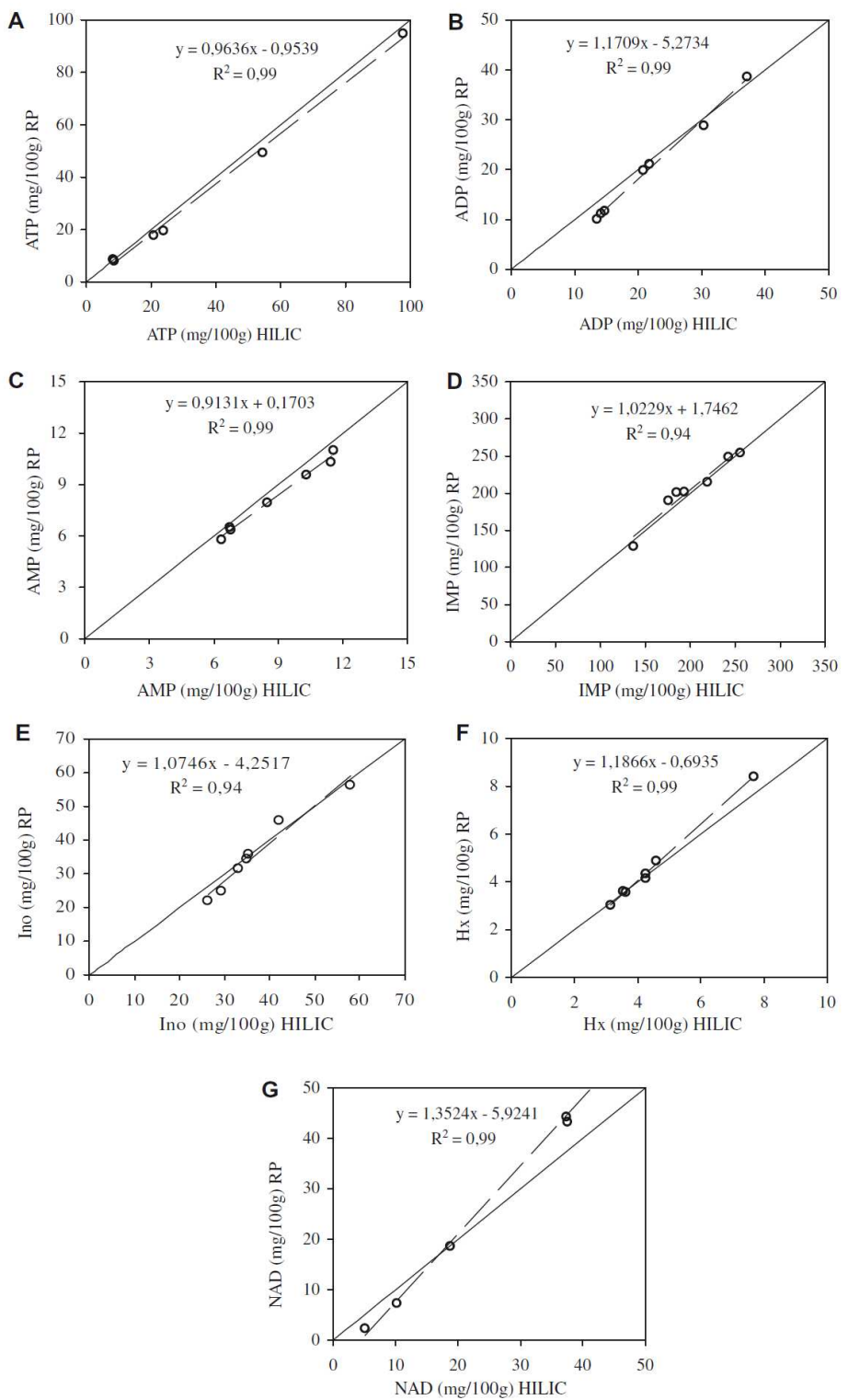

Fig. 3. Correlations between the HILIC method developed in this work and the ion-pair reversed-phase method with respect to the studied analyte concentrations. The solid line indicates perfect correspondence $(x=y)$ and the broken line the results obtained after analysis. (A) Adenosine triphosphate; (B) adenosine diphosphate; (C) adenosine

within the studied concentration range with regression coefficients greater than 0.99. The linearity of the method for all compounds was as good as that obtained with other methods (Coolen et al., 2008) 
The LD for the different compounds were $1.72,0.16,0.05,0.15$, $0.16,0.15$ and $0.10 \mu \mathrm{g} / \mathrm{mL}$ for $\mathrm{Hx}$, Ino, AMP, NAD, IMP, ADP and ATP, respectively (see Table 3 ). As can be observed, hypoxanthine detection limit was considerably higher than the rest of the LDs due to the baseline disturbance caused by the salt gradient which promote an increase of the absorption at $254 \mathrm{~nm}$ at such time (6.5 min).

Repeatability and reproducibility data, shown in Table 3, demonstrated very good results from one analysis to another. Results agree with those reported by other authors for $5 \mathrm{~h}$ post-mortem pork muscle analysed using other methods (Batlle et al., 2000, 2001; Tsai, Cassens, Briskey, \& Greaser, 1972). The percentage of recovery determined after the addition of known amounts of the analytes to $5 \mathrm{~h}$ post-mortem meat samples is shown in Table 4 and ranged between $94.8 \%$ and $121.6 \%$.

\subsection{Comparison between HILIC and IP-RP-HPLC methods}

Pork meat samples at different post-mortem times were analysed to determine ATP, ADP, AMP, IMP, Ino, $\mathrm{Hx}$ and $\mathrm{NAD}^{+}$concentrations by both HILIC and IP-RP-HPLC methodology, using a $\mathrm{ZIC}^{\circledR}$ - $p$ HILIC column and a Zorbax Eclipse XDB-C18 column, respectively. Results obtained after analysing 5, 7, 9, 11, 27, 51 and $171 \mathrm{~h}$ post-mortem pork meat were very similar to those published by other authors in this type of samples (Batlle et al., 2001; Tsai et al., 1972) (results not shown). The analysis of variance revealed non-significant differences in the use of both columns in almost all compounds and post-mortem times, although significant differences were observed at $171 \mathrm{~h}$ in $\operatorname{NAD}^{+}(p<0.01)$ and at 27,51 and $171 \mathrm{~h}$ in $\operatorname{ADP}(p<0.001)$ analysis (data not shown). On the other hand, Fig. 3 illustrates the correlation between the data obtained by HILIC and IP-RP-HPLC methods. A good agreement was found between the two sets of data with correlation coefficients of 0.99 for ATP, ADP, AMP, Hx and NAD ${ }^{+}$and 0.94 for IMP and Ino. These results prove the precision and reliability of both methods using these columns (Batlle et al., 2001).

\section{Conclusion}

The HILIC method developed in this study allows the analysis of ATP, ADP, AMP, IMP, Ino, Hx and the dinucleotide NAD ${ }^{+}$in meat samples. The method has been optimised and adequate levels of linearity, repeatability, reproducibility, recovery and sensitivity prove that the proposed method is a good alternative for isolating and quantifying nucleotides in complex matrices such as meat. A comparison between the concentrations of the compounds measured by HILIC using a ZIC ${ }^{\circledR}-p$ HILIC column and by IP-RP-HPLC using a Zorbax Eclipse XDB-C18 column has also been done, obtaining very good agreement between the two sets of data. Thus, obtaining very good agreement between the two sets of data. Thus,
HILIC constitutes a valid and reliable method to analyse ATP and its HILIC constitutes a valid and reliable method to analyse ATP and its
metabolites, being an interesting alternative to other methodologies. Finally, this method has also shown high effectivity in the isolation of guanosine, GMP, GDP, GTP, Cn and UA standards. This fact could result very interesting in the identification and quantification of these compounds in meat products.

\section{Acknowledgments}

FPU Scholarship from Ministerio de Ciencia y Educación (Spain) to L.M. and scholarship from Consejo Nacional de Ciencia y Tecnología (CONACyT) and Colegio de Postgraduados (México) to A.S.H.-C. are fully acknowledged. Agroalimed grant from Consellería de Agricultura, Pesca y Alimentación (Generalitat Valenciana, Spain) and AGL2007-65379-C02-01 from Ministry of Science and Innovation (Spain) and FEDER funds are also acknowledged.

\section{References}

Alpert, A. J. (1990). Hydrophilic-interaction chromatography for the separation of peptides, nucl $177-196$

ristoy, M. C \& Toldrá. F. (2009) Nucleotides and its derived compounds. In L M. L Nollet \& F. Toldrá (Eds.), Handbook of muscle foods analysis (pp. 279-288)

BocaRaton FL, USA: CRC Press.
Batlle, N., Aristoy, M. C., \& Toldrá, F. (2000). Early postmortem detection of exudative pork meat based on nucleotide content. Journal of Food Science, 65 $413-416$.

Aristoy, M. C. \& Toldrá, F. (2001). ATP metabolites during aging of exudative and nonexudative pork meats. Joumal of Food Science, 66, 68-71. hypoxanthine content in fish tissue. Journal of the Association of Official Analytical Chemists, 68, 444-448.

Cambero, M. L., Pereira-Lima, C. L., Ordonez, J. A., \& de Fernando, G. D. G. (2000). Beef (the flavour developed at differen 1519-1528.

Coolen, E. . C. M., Arts, I. C. W.., Swennen, E. L. R., Bast, A., Stuart, M. A. C., \& Dagnelie, P. C. (2008). Simultaneous determination of adenosine triphosphate and its metabolites in human whole blood by RP-HPLC and UV-detection. Journal of Chromatography B - Analytical Technologies in the Biomedical and Life Sciences, $864,43-51$

nucleotides in muscle of lobster Homarus americanus. Journal of Food Science, 33, 100-103.

Fujita, T., Hori, Y., Otani, T., Kunita, Y., Sawa, S., Sakai, S., et al. (1988). Applicability of the KO value as an index of freshness for porcine and chicken muscles. Agricultural and Biological Chemistry, 52, 107-112.

Gao, R. C., Xue, C. H Yuan, L., Li, Z. J., Xue, Y., Cui, F. X., et al. (2006). Determination of he big head carp myofibrillar (Aristichthys nobilis) adenosine triphosphatase activity by ion chromatography. Journal of Chromatography A, 1118, 278-280.
Gariod, L., Binzoni, T., Ferretti, G., Lebas, I. F., Reutenauer, H. \& Cerretelli, P. (1994) Standardization of (31)phosphorus-nuclear magnetic-resonance spectrosco determinations of high-energy phosphates in humans. European Journal of

Hattula. T.. \& Kiesvaara, M. (1996). Breakdown products of adenosine triphosphate theated fishery products as an indicator of raw material freshness and of Technologie, 29, 135-139.

Jones, N. R., Murray, C. K., Livingst, E. l., \& Murray, J. (1964). Rapid estimations of hypoxanthine concentrations as indices of freshness of chill-stored fish. Journ of the Science of Food and Agriculture, 15, 763-774.

ida, T., Fujita, M., Goto, H., \& Yano, T. (2007). Effects of freshness on ATP-related Scomber japonicus. Food Science and Technology - Lebensmittel-Wissenschaft \& Technologie, 40, 1186-1 190. macrocycle-based ion chromatography. Journal of Chromatography, 602,

Luong. J. H. T., \& Male, K. B. (1992). Development of a new biosensor system for the determination of the hypoxanthine ratio, an indicator of fish freshness. Enzyme
and Microbial Technology, 14, 125-130.

Macy, R. L Naumann, H. D. \& Bailey, M. E. (1970). Water-soluble flavor and odor precursors of meat. 5. Influence of heating on acid-extractable non-nucleotide chemical constituents of beef, lamb and pork. Joumal of Food Science, 35, 83-87. Meynial, I... Paquet, V.. \& Combes, D. (1995). Simultaneous separation of nucleotides assaying glycosyltransferase activity. Analytical Chemistry, 67, 1627-1631. array I \& Thomson, A. B. (1983) Reverse phase ion-pair separation of nucleotides and related products in fish muscle. Journal of High Resolution Chromatography \& Chromatography Communications, 6, 209-210.

Nguyen, A. L., Luong, J. H. T.. \& Masson, C. (1990). Determination of nucleotides 2490-2493.

Oertel, R., Neumeister, V., \& Kirch, W. (2004). Hydrophilic interaction hromatography combined with tandem-mass spectrometry to determine six aminoglycosides in serum. Journal of Chromatography A, 1058, 197-201.

Roberts, B., Morris, B. A., \& Clifford, M. N. (1991). Comparison of radioimmunoassay and spectrophotometric analysis for the quantitation of hypoxanthine in fish muscle. Food Chemistry, 42, 1-17.

Saito, T., Araki, K., \& Matsuyoshi, M. (1959). A new method for estimating the

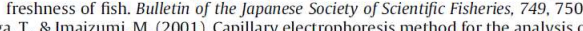
inorganic anions, organic acids, amino acids, nucleotides, carbohydrates and other anionic compounds. Electrophoresis, 22, 3418-3425.

Strege, M. A. (1998). Hydrophilic interaction chromatography electrospray mas sectrometry analysis of polar compounds for natural product drug discovery.

(1972). Studies on nucleotide 37, 612-616.

Van den Thillart, G., Van Waarde, A., Muller, H. J., Erkelens, C., \& Lugtenburg, 
- 31P-NMR spectroscopy and enzymatic methods. Comparative Biochemistry and Physiology B Bloctiemistry e Molecular biology, $95,789-795$. Determination of ATP related compounds in fresh and canned tuna fish by

Watanabe, E... Ando. K.-Karube, I.. Matsuoka, H.. \& Suzuki. S. (1983). Determination of hypoxanthine in fish meat with an enzyme sensor. Journal of Food Science, 48
Yano, Y., Kataho, N., Watanabe, M., Nakamura, T., \& Asano, Y. (1995). Evaluation of beef aging by determination of hypoxanthine and xanthine contents Application of a xanthine sensor. Food Chemistry, 52, 439-445.

A review. (2004). Peptide separation by hydrophilic-interaction chromatography: 



\section{Anexo C}

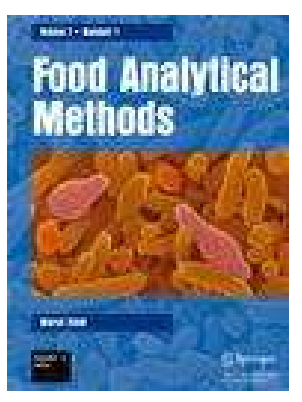

Hydrophilic Interaction Chromatographic (HILIC) in the Analysis of Relevant Quality and Safety Biochemical Compounds in Meat, Poultry and Processed Meats Leticia Mora, Aleida S. Hernández-Cázares, M-Concepción Aristoy, Fidel Toldrá, Milagro Reig

Food Analytical Methods. DOI 10.1007/s12161-010-9149-1

Published online: 22 May 2010 



\section{Hydrophilic Interaction Chromatography (HILIC) in the Analysis of Relevant Quality and Safety Biochemical Compounds in Meat, Poultry and Processed Meats}

Leticia Mora • Aleida S. Hernández-Cázares

M-Concepción Aristoy • Fidel Toldrá • Milagro Reig

Abstract HPLC methods based on hydrophilic interaction chromatography (HILIC) have been recently applied to the analysis of biochemical compounds, related to the quality, in meat and poultry as well as meat products like cooked ham and dry-cured ham. This type of chromatography has also been successfully used for the analysis of antibiotic residues in meat and poultry. HILIC chromatography has an increasing relevance for the analysis of polar compounds in foods due to its good retention without need for derivatisation. In general, HILIC-based methods have shown good performance for the analysis of polar biochemical compounds like dipeptides, creatine and creatinine, nucleotides and nucleosides, sphingolipids and residues, mainly antibiotics, in rather complex matrices such as muscles. Thus, this manuscript presents a review of recent applications of HILIC methods for the analysis of quality-related biochemical compounds and residues in meat, poultry and processed meats.

Keywords HILIC · HPLC · Polar Compounds · Dipeptides . Sphingolipids $\cdot$ Nucleotides and Nucleosides

\author{
L. Mora · A. S. Hernández-Cázares · M.-C. Aristoy \\ F. Toldrá $(\bowtie)$ \\ Instituto de Agroquímica y Tecnología de Alimentos (CSIC), \\ Avda. Agustín Escardino, 7, 46980 Patema, (Valencia), Spain \\ e-mail: ftoldra@iata.csic.es \\ M. Reig \\ Institute of Food Engineering for Development, \\ Universidad Politécnica de Valencia,
}

Camino de Vera s/n, 46022 Valencia, Spain

Published online: 22 May 2010

\section{Introduction}

The versatility, short analysis time and high resolution of high-performance liquid chromatography (HPLC) have made this technique a method of choice for the analysis of biochemical compounds in meat, poultry and meat products.

Reverse-phase liquid chromatography (RP-HPLC) has been a very useful technique for the separation of meatderived compounds (Dunnett et al. 1991; Dunnett and Harris 1992; Tranberg et al. 2005) because of its powerful resolving capacity, with the additional advantage for the use of volatile mobile phases that avoid the need of sample desalting. In spite of this, RP-HPLC presents a major limitation consisting of the low retention of polar molecules. Normal-phase liquid chromatography (NP-HPLC) has been traditionally used to separate polar compounds with non-aqueous mobile phases, but an important limitation is the difficulty to dissolve hydrophilic compounds in these phases (Yoshida 2004). In those cases, HILIC is an alternative to conventional RPHPLC or NP-HPLC since this type of chromatography has proven to be quite convenient for the analysis of small polar molecules weakly retained or eluted with dead volume in conventional RP-HPLC systems (Grumbach et al. 2004; Strege 1998; Grumbach et al. 2003; Guo and Gaiki 2005; Schlichtherle-Cerny et al. 2003), and very good results have been obtained in coupling this type of liquid chromatography to mass spectrometry (MS) detection (Ciminiello et al. 2005; de Person et al. 2005; Fischbeck et al. 2009; Gianotti et al. 2008).

In HILIC, an initial mobile phase with a high content of an organic solvent is used to promote hydrophilic interactions between the analyte and the polar hydrophilic stationary phase. In this context, silica, amino and polymeric stationary phases compatible with aqueous mobile

Springer 
phases offer potential use in the HILIC mode (Ciminiello et al. 2005). Acetonitrile is usually the first choice as organic solvent for HILIC due to its good miscibility with water, the good HILIC retention and the low viscosity. HILIC mode is similar to normal-phase chromatography since polar compounds are retained longer than the non-polar ones, and the polar component of the mobile phase (usually water) is the strong solvent used to elute the compounds However, regarding the solubility of analytes in the mobile phase and matrix compatibility, HILIC shows a better performance than normal-phase chromatography because the nature of the used mobile phases is comparable to reverse-phase separations (Yoshida 2004).

The availability of commercial silica, amino and polymeric columns compatible with aqueous mobile phases has prompted a rapid development of HILIC chromatography for the separation of polar compounds (Alpert 1990). It offers several advantages like the better solubility of biological substances and, additionally, the samples do not need a desalting step or further derivatisation (Strege 1998; Oertel et al. 2004a, b).

HILIC separations can be easily combined with several detection techniques such as ultraviolet absorbance (Huttunen et al. 2009), fluorescence (Ahn et al. 2010), refractive index (Guo and Huang 2003) and MS (Andersen et al. 2008; Gianotti et al. 2008; Kovalova et al. 2009). HILIC methodology used with electrospray ionisation and coupled to MS detection results in higher sensitivity compared to RP-HPLC, probably due to the high content of organic solvent in the mobile phase, which simplify the drop formation during the spray process.

HILIC methodology has been widely applied during the last decades in the analysis of compounds of interest in food (Schlichtherle-Cerny et al. 2003; Fenaille et al. 2004; de Person et al. 2005; Rotzoll et al. 2005) and has also increased its popularity during the last decades in the analysis of drugs (Oertel et al. 2004a; Peru et al. 2006; Zheng et al. 2008; Ishii et al. 2008; Kesiunaite et al. 2008; Kovalova et al. 2009) and contaminant residues (Dixon et al. 2004; Zywicki et al. 2005; Lojkova et al. 2006; Chung et al. 2007; Andersen et al. 2008; Gianotti et al. 2008; Jiang and Ihunegbo 2009) in different types of foods. In this manuscript, we review the recent developments on HILIC chromatography applied to the analysis of certain biochemical compounds and antibiotic residues in the meat field.

Relevance for the HILIC Analysis of Biochemical Compounds in Meat, Poultry and Processed Meats

HILIC has been considered as an interesting alternative to the most typical chromatographic techniques due to its advantages with regards to simplicity, reliability and adaptability to subsequent analysis by mass spectrometry. HILIC has been applied in meat, poultry and meat products for the analysis of sphingolipids such as sphingomyelin (Fischbeck et al. 2009), dipeptides carnosine, anserine, $\beta$ alanylglycine and balenine (BAL) (Dunkel and Hofmann 2009; Mora et al. 2007) and the determination of biochemical markers involved in the energetic metabolism of muscles such as creatine, creatinine (Mora et al. 2007; Mora et al. 2008a; Mora et al. 2008b) and some nucleotides and nucleosides (Mora et al. 2009). Brief descriptions for such assays are given below while more methodological details are given in Tables 1 and 2 .

Dipeptides

The imidazole dipeptide carnosine (CAR) and its methylated analogues anserine (ANS) and BAL are histidine-containing dipeptides widely distributed in vertebrate animal tissues, especially skeletal muscle, heart and the central nervous system (Crush 1970). Carnosine and anserine are the most abundant antioxidants in meat. Their antioxidant activities may result from their ability to chelate transition metals such as copper (Brown 1981). These antioxidative peptides have been reported to play many roles such as wound healing, recovery from fatigue and prevention of diseases and ageing related to oxidative stress (Hipkiss et al. 1998; Hipkiss 1998; Hipkiss and Brownson 2000).

The content of these dipeptides is especially high in muscles with glycolytic metabolism, although this also depends on the animal species, age and diets fed to the animal (Aristoy and Toldrá 1998; Cornet and Bousset 1998). The distribution of these dipeptides and their ratios, carnosine/anserine and balenine/anserine, are specific to each animal species and has been used to discriminate between beef, pork, horse, deer, chicken and turkey meats in processed meat products (Abe and Okuma 1995). In fact, carnosine/anserine ratios of poultry meat extracts have also been used to estimate the single meat species (chicken, duck and turkey) in uncooked and cooked meat products (Huang and Kuo 2000). In relation to this, the relative amounts of carnosine and anserine were used for detecting the presence of proteins of mammalian origin in feeds for ruminants, and thus, the molar ratio of carnosine/anserine allowed the discrimination between mammalian and nonmammalian species eventually added to feeds (Aristoy and Toldrá 2004; Aristoy et al. 2004). These dipeptides also contribute to the characteristic flavour of beef (Pereira-Lima et al. 2000) and chicken (Dunkel and Hofmann 2009) broths.

\section{Sphingolipids}

Sphingolipids represent a class of lipids derived from the aliphatic amino alcohol sphingosine and are found in all eukaryotic cells. There are three types of sphingolipids: sphingomyelins, glycosphingolipids and gangliosides. 
Table 1 Main chromatographic conditions used in HILIC for the separation of biochemical compounds in meat and meat products using HPLCDAD methodology

\begin{tabular}{|c|c|c|c|c|c|c|c|c|c|c|}
\hline Method & \multicolumn{3}{|l|}{ A } & \multicolumn{2}{|l|}{ B } & \multicolumn{5}{|l|}{ C } \\
\hline Componds analysed & \multicolumn{3}{|c|}{$\begin{array}{l}\text { Carnosine, Anserine, Balenine, } \\
\text { Creatine, Creatinine }\end{array}$} & \multicolumn{2}{|c|}{ Creatine, Creatinine } & \multicolumn{5}{|c|}{ Nucleotides and nucleosides } \\
\hline Matrices & \multicolumn{3}{|c|}{$\begin{array}{l}\text { Pork raw meat, cooked ham, dry } \\
\text { cured ham }\end{array}$} & \multicolumn{2}{|c|}{ Dry cured ham } & \multicolumn{5}{|c|}{$\begin{array}{l}\text { Pork raw meat, cooked ham, dr } \\
\text { cured ham }\end{array}$} \\
\hline Column & \multicolumn{3}{|c|}{$\begin{array}{l}\text { Atlantis }{ }^{\circledast} \text { HILIC Silica } \\
\text { (Waters, Milford, MA) } \\
(4.6 \times 150 \mathrm{~mm}, 3 \mu \mathrm{m})\end{array}$} & \multicolumn{2}{|c|}{$\begin{array}{l}\text { ZIC } \text { ZICHILIC }^{\infty} \text { (SeQuant, Umeå, Sweden) } \\
(4.6 \times 150 \mathrm{~mm}, 5 \mu \mathrm{m}) \\
\end{array}$} & \multicolumn{5}{|c|}{$\begin{array}{l}\mathrm{ZIC}^{\mathrm{K}} \text {-pHILIC } \\
(4.6 \times 150 \mathrm{~mm}, 5 \mu \mathrm{m})\end{array}$} \\
\hline Guard column & \multicolumn{3}{|c|}{$\begin{array}{l}\text { Atlantis HILIC Silica } \\
(4.6 \times 20 \mathrm{~mm}, 3 \mu \mathrm{m})\end{array}$} & \multicolumn{2}{|c|}{$\begin{array}{l}\text { ZIC }^{18} \text {-pHILIC } \\
(2.1 \times 20 \mathrm{~mm}, 5 \mu \mathrm{m})\end{array}$} & \multicolumn{5}{|c|}{$\begin{array}{l}\mathrm{ZIC}^{\sqrt{6}} \text {-pHILIC } \\
(2.1 \times 20 \mathrm{~mm}, 5 \mu \mathrm{m})\end{array}$} \\
\hline Flow rate & \multicolumn{3}{|c|}{$1.4 \mathrm{~mL} / \mathrm{min}$} & \multicolumn{2}{|l|}{$0.5 \mathrm{~mL} / \mathrm{min}$} & \multicolumn{5}{|c|}{$0.5 \mathrm{~mL} / \mathrm{min}$} \\
\hline Temperature & \multicolumn{3}{|c|}{ Room temperature } & \multicolumn{2}{|c|}{ Room temperature } & \multicolumn{5}{|l|}{$28^{\circ} \mathrm{C}$} \\
\hline UV Detection waveleght & \multicolumn{3}{|c|}{214 and $236 \mathrm{~nm}$} & \multicolumn{2}{|c|}{214 and $236 \mathrm{~nm}$} & \multicolumn{5}{|c|}{$254 \mathrm{~nm}$} \\
\hline \multirow[t]{7}{*}{ Separation conditions } & \begin{tabular}{|l} 
Time \\
$(\min )$
\end{tabular} & A & B & \begin{tabular}{|l|l|}
$\begin{array}{l}\text { Time } \\
(\min )\end{array}$ & $\mathrm{A}$ \\
\end{tabular} & B & \begin{tabular}{|l|} 
Time \\
$(\mathrm{min})$
\end{tabular} & A & B & $\mathrm{C}$ & D \\
\hline & 0 & 100 & 0 & 100 & 0 & 0 & 15 & 0 & 80 & 5 \\
\hline & 13 & 0 & 100 & \begin{tabular}{l|l|}
30 & 0 \\
\end{tabular} & 100 & 3 & 0 & 25 & 70 & 5 \\
\hline & & & & & & 15 & 0 & 25 & 70 & 5 \\
\hline & & & & & & 25 & 0 & 50 & 40 & 10 \\
\hline & & & & & & 35 & 0 & 50 & 40 & 10 \\
\hline & \multicolumn{3}{|c|}{$\begin{array}{l}\text { A: } 0.65 \mathrm{mM} \text { ammonium acetate, } \mathrm{pH} 5.5 \\
\text { in water/acetonitrile ( } 25: 75) \\
\text { B: } 4.55 \mathrm{mM} \text { ammonium acetate, } \mathrm{pH} 5.5 \\
\text { in water/acetonitrile }(70: 30)\end{array}$} & \multicolumn{2}{|c|}{$\begin{array}{l}\text { A: } 1 \mathrm{mM} \text { ammonium acetate, } \mathrm{pH} 5.5 \\
\text { in water/acetonitrile (20:80) } \\
\text { B: } 1 \mathrm{mM} \text { ammonium acetate, } \mathrm{pH} 5.5 \\
\text { in water/acetonitrile }(70: 30)\end{array}$} & \multicolumn{5}{|c|}{$\begin{array}{l}\text { A: } 150 \mathrm{mM} \text { ammonium acetate, } \mathrm{pH} 3.5 \\
\text { B: } 100 \mathrm{mM} \text { ammonium acetate, } \mathrm{pH} 7.0 \\
\text { C: Acetonitrile } \\
\text { D: Water }\end{array}$} \\
\hline References & & & lora et al. 2007 & Mora & et al. 2010 & & & ora et & 2009 & \\
\hline
\end{tabular}

* The described chromatographic methods has been tested with these matrices and chromatograms obtained are included in the review

The sphingolipid metabolism constitutes a sequential formation of biologically active compounds. In fact, sphingolipids and its hydrolysis products are considered protective against carcinogenesis. It has been suggested that biologically active metabolites of sphingolipids may influence cell differentiation and tumour development in the gut (Merrill et al. 1997), whereas the administration of low concentrations of sphingolipids such as sphingomyelin inhibit colon cancer in mice (Lemonnier et al. 2003; Schmelz et al. 1997, 2000; Schmelz and Merrill 1998; Simon et al. 2009). In fact, sphingomyelin supplementation at $0.1 \%$ of the diet $(w / w)$ has reduced the number of an early marker of colon carcinogenesis by $70 \%$ as well as the number of adenocarcinomas in mice treated to induce colon tumours (Schmelz et al. 1996, 1997; Dillehay et al. 1994). A decrease in sphingomyelinase activity has been described in colorectal carcinomas, being an early event in the development of this type of cancer (Hertervig et al. 1997). On the other hand, the action of sphingomyelin itself has been also related to a reduction in the cholesterol absorption (Fischbeck et al. 2009; Eckhardt et al. 2001, 2002; Nyberg et al. 2000).

Despite the potential of these compounds to be protective against carcinogenesis, the physiological effects of their consumption in humans as well as their content in different foodstuffs still remain elusive. Sphingolipids are present in considerable amounts in foods such as soy and dairy products. Recently, some studies have been focused in the determination of these compounds in different types of meat and fish (Fischbeck et al. 2009; Hellgren 2001).

\section{Creatine and Creatinine}

Creatine and creatine phosphate play a critical role in muscle energy metabolism. They are responsible for the rapid energy provision during muscle contraction, involving the transfer of $N$-phosphoryl group from creatine phosphate $(\mathrm{PCr})$ to adenosine diphosphate (ADP) to regenerate adenosine triphosphate (ATP) through a reversible reaction catalysed by creatine kinase enzyme (Wyss and Kaddurah-Daouk 2000). These compounds play an important role in the energy metabolism of skeletal muscle, taking part in the post-mortem biochemical processes occurring immediately after slaughter (Toldrá 2006a). There is also extensive evidence that, under some circumstances, creatine supplements can enhance muscle performance (Demant and 
Table 2 Main chromatographic conditions used in HILIC for the separation of biochemical compounds in meat and meat products using LC-MS MS methodology

\begin{tabular}{|c|c|c|c|c|c|c|c|c|c|}
\hline Method & \multicolumn{3}{|l|}{ D } & \multicolumn{3}{|l|}{$\mathbf{E}$} & \multicolumn{3}{|l|}{$\mathrm{F}$} \\
\hline Componds analysed & \multicolumn{3}{|c|}{ Sphingomyelin } & \multicolumn{3}{|c|}{ Nucleotides and nucleosides } & \multicolumn{3}{|c|}{$\begin{array}{l}\text { Anserine, Carnosine, } \beta \text { - } \\
\text { alanylglycine }\end{array}$} \\
\hline Matrices & \multicolumn{3}{|c|}{$\begin{array}{l}\text { Pork, beef, wild boar, roe deer } \\
\text { tissues }\end{array}$} & \multicolumn{3}{|c|}{ Chicken broth } & \multicolumn{3}{|c|}{ Chicken broth } \\
\hline Column & \multicolumn{3}{|c|}{$\begin{array}{l}\text { LiChroCART }{ }^{\oplus} \text { Li Chrospher Si } 60 \\
\text { (Merck, Darmstadt, Germany) } \\
\text { (250x } 4 \mathrm{~mm}, 10 \mu \mathrm{m} \text { ) }\end{array}$} & \multicolumn{3}{|c|}{$\begin{array}{l}\text { TSKgel }^{\otimes} \text { Amide-80 } \\
\text { (Tosoh Bioscience, Stuttgart, } \\
\text { Germany) } \\
(300 \times 7.8 \mathrm{~mm}, 5 \mu \mathrm{m})\end{array}$} & \multicolumn{3}{|c|}{$\begin{array}{l}\text { TSKgel }^{\circledast} \text { Amide- } 80 \\
(300 \times 7.8 \mathrm{~mm}, 5 \mu \mathrm{m})\end{array}$} \\
\hline Guard column & \multicolumn{3}{|c|}{$-\cdots-$} & \multicolumn{3}{|c|}{$-\cdots$} & \multicolumn{3}{|c|}{$-\cdots$} \\
\hline Flow rate & \multicolumn{3}{|c|}{$1 \mathrm{~mL} / \mathrm{min}$} & \multicolumn{3}{|c|}{$1 \mathrm{~mL} / \mathrm{min}$} & \multicolumn{3}{|c|}{$1 \mathrm{~mL} / \mathrm{min}$} \\
\hline Temperature & \multicolumn{3}{|c|}{----} & \multicolumn{3}{|c|}{$-\cdots$} & \multicolumn{3}{|c|}{$-\cdots-$} \\
\hline Ionization mode & \multicolumn{3}{|c|}{ Positive } & \multicolumn{3}{|c|}{ Positive } & \multicolumn{3}{|c|}{ Positive } \\
\hline \multirow[t]{6}{*}{ Separation conditions } & \begin{tabular}{|l}
$\begin{array}{l}\text { Time } \\
\text { (min) }\end{array}$ \\
\end{tabular} & A & B & \begin{tabular}{|l|} 
Time \\
$(\mathrm{min})$ \\
\end{tabular} & $\mathrm{A}$ & B & \begin{tabular}{|l} 
Time \\
$(\mathrm{min})$
\end{tabular} & $\mathrm{A}$ & B \\
\hline & 0 & 95 & 5 & 0 & 75 & 25 & 0 & 70 & 30 \\
\hline & 5 & 95 & 5 & 10 & 75 & 25 & 10 & 70 & 30 \\
\hline & 20 & 38 & 62 & 40 & 50 & 50 & 50 & 40 & 60 \\
\hline & & & & 50 & 0 & 100 & 55 & 0 & 100 \\
\hline & \multicolumn{3}{|c|}{$\begin{array}{l}\text { A: } 1 \% \text { formic acid in acetonitrile } \\
\text { B: } 1 \% \text { formic acid in water }\end{array}$} & \multicolumn{3}{|c|}{$\begin{array}{l}\text { A: } 1 \% \text { formic acid in acetonitrile } \\
\text { B: } 1 \% \text { formic acid in water }\end{array}$} & \multicolumn{3}{|c|}{$\begin{array}{l}\text { A: } 1 \% \text { formic acid in acetonitrile } \\
\text { B: } 1 \% \text { formic acid in water }\end{array}$} \\
\hline References & \multicolumn{3}{|c|}{ Fischbeck et al. 2009} & \multicolumn{3}{|c|}{ Dunkel and Hofmann 2009} & \multicolumn{3}{|c|}{ Dunkel and Hofmann 2009} \\
\hline
\end{tabular}

Rhodes 1999). On the other hand, creatine (Cr) turns into creatinine $(\mathrm{Cn})$ in muscle due to a non-enzymatic conversion by the removal of water and the formation of a ring structure. This reaction takes place easily under heating conditions (Pais et al. 1999). The addition of creatine to broths has also been strongly recommended because of its contribution to the full flavour of meat extracts (Schlichtherle-Cerny and Grosch 1998; Cambero et al. 2000). However, the presence of creatine and creatinine in cooked meat has also been associated to negative aspects because creatine and creatinine can constitute important precursors of heterocyclic amines formed on the surface of meat when it is cooked at high temperatures such as roasting, frying and grilling (Pais et al. 1999).

\section{Nucleotides and Nucleosides}

The analysis of nucleotides and nucleosides resulting from the ATP degradation into ADP, adenosine monophosphate (AMP) and inosine $5^{\prime}$-monophosphate (IMP), which is degraded to Ino (inosine) and Hx (hypoxanthine), has been proposed as a rapid method of early post-mortem prediction of meat quality (Batlle et al. 2000, 2001) and/or meat freshness (Saito et al. 1959). The degradation of adenosine nucleotides to IMP and Ino in pale, soft and exudative and dark, firm and dry muscles occurs much faster than in normal muscles. Thus, the $R^{\prime}$ value (ratio of Ino-related compounds to adenosine-related compounds) and the ratio IMP/ATP were suggested as a simple value to detect and discriminate exudative pork meats at $2 \mathrm{~h}$ post-mortem (Batlle et al. 2000) Some other ratios such as $K_{0}(((\mathrm{Ino}+\mathrm{Hx}+\mathrm{X}) /(\mathrm{ATP}+\mathrm{ADP}+$ $\mathrm{AMP}+\mathrm{IMP}+$ adenosine $+\mathrm{Ino}+\mathrm{Hx}+\mathrm{X})) \times 100)($ Fujita et al $1988), K$ value $(((\mathrm{Ino}+\mathrm{Hx}) /(\mathrm{ATP}+\mathrm{ADP}+\mathrm{AMP}+\mathrm{IMP}+\mathrm{Ino}+$ Hx) $\times 100$ ) (Saito et al. 1959; Okuma and Abe 1992), $K$ value $(((\mathrm{Ino}+\mathrm{Hx}) /(\mathrm{IMP}+\mathrm{Ino}+\mathrm{Hx})) \times 100)($ Karube et al 1984; Volpe and Mascini 1996) and Hx ratio or $\mathrm{H}$ value $(\mathrm{Hx} /(\mathrm{IMP}+\mathrm{Ino}+\mathrm{Hx}))$ (Luong et al. 1992; Luong and Male 1992) have been also proposed as freshness indexes and applied to different fish species (Jones et al. 1964; Luong and Male 1992; Volpe and Mascini 1996; Hattula and Kiesvaara 1996), beef (Yano et al. 1995), poultry and pork meat (Fujita et al. 1988). On the other hand, nucleotide 
compounds have a relation with sensory attributes. The IMP and guanosine monophosphate (GMP), flavour enhancers, have been associated to meat flavour due to their contribution in the umami taste (Calkins et al. 1982; Fish 1991; Aliani and Farmer 2005), whereas the Hx together with some amino acids and peptides may contribute to bitter taste (Tikk et al. 2006).

In this context, the hydrophilic nature of the dipeptides carnosine, anserine and balenine, the biomarkers creatine and creatinine and the main nucleotides and nucleosides makes these compounds adequate analytes for hydrophilic interaction chromatography.

\section{Analysis of Biochemical Compounds in Meat, Poultry and Meat Products}

\section{Extraction Procedure}

The extraction procedure is a fundamental stage in the analysis of compounds contained in meat, poultry and meat products. With regard to creatine and creatinine extraction, temperature is a very important parameter to be controlled due to its influence on creatine conversion to creatinine. For this reason, the sampling and the extraction procedure is done under refrigeration at $4{ }^{\circ} \mathrm{C}$. ATP-derived compounds are very unstable in muscle during the early post-mortem period. Its degradation occurs very fast even under refrigeration at $4{ }^{\circ} \mathrm{C}$. Therefore, it is fundamental to immediately freeze raw meat samples during first hour post-mortem to avoid ATP degradation by means of immersion with liquid nitrogen.

In meat, poultry and meat products, the extraction of dipeptides, creatine and creatinine is usually made using diluted acid solutions such as clorhidric acid. After extraction, samples are deproteinised by adding three volumes of acetonitrile, methanol or ethanol. In the extraction of nucleotides and nucleosides, extraction and deproteinisation procedures are made in one step using a deproteinising solvent such as perchloric acid (Dunnett and Harris 1997; Martín et al. 2001; Liu et al. 2007) or trifluoroacetic acid (Hughes et al. 2002). The extraction of sphingolipids compounds in raw meat and poultry is carried out using a mixture of organic solvents such as chloroform/ methanol, although for a further cleanup, the crude lipid extract is applied to a silica gel column (Fischbeck et al. 2009).

The usual extraction procedure employed in meat broths is very simple. Extraction is done using organic solvents such as $n$-pentane to eliminate fat, whereas the residual aqueous layer can be directly used in the analysis (Dunkel and Hofmann 2009). Subsequent treatments, such as ultrafiltration or size-exclusion chromatography, are frequently carried out to simplify the sample.
Chromatographic Determination

The simultaneous determination of carnosine, anserine, balenine, creatine and creatinine in pork loin and chicken breast meat was recently developed using an Atlantis silica column from Waters (Mora et al. 2007). This chromatographic method was subsequently applied to seven pork muscles of different metabolic type (Mora et al. 2008a). The comparison is interesting because muscles exert different in vivo physiological conditions which are also reflected in post-mortem meat where many relevant differences are found between glycolytic and oxidative metabolic types, i.e., different myoglobin content, amino acids profile and some enzymes activity like lactic acid dehydrogenase (Aristoy and Toldrá 1998). According to the obtained results, the content of creatine and creatinine were significantly higher in glycolytic muscles such as semimembranosus, biceps femoris, gluteus maximus and longissimus dorsi whereas masseter, a red oxidative muscle, was characterised by the lowest contents of these compounds (Mora et al. 2008a). As can be appreciated in Fig. 1, the chromatograms showed relevant differences in the content of creatine, creatinine and natural dipeptides between both muscles, which are larger in the glycolytic (Fig. 1a) than in the oxidative one (Fig. 1b), following a similar trend to what was previously observed by other authors in the case of carnosine (Aristoy and Toldrá 1998).

The analysis of nucleotides and nucleosides in raw meat and poultry is also transcendental to follow the post-mortem changes occurring just after slaughter. The study of the evolution of the ATP degradation at early post-mortem can give a good indication of the final quality of meat. Different analytical techniques have been used for the detection of these compounds. A comparison between pork meat concentrations of nucleotides and nucleosides analysed by HILIC, using a zwitterionic polymeric ZIC-pHILIC column (SeQuant), and by ion-pair reversed-phase chromatography, using a Zorbax Eclipse XDB-C18 column (Agilent, Palo Alto, CA), was performed (Mora et al. 2009). In this study, the simultaneous analysis of ATP, ADP, AMP, IMP, Ino, Hx, nicotinamide adenine dinucleotide $\left(\mathrm{NAD}^{+}\right)$and creatinine $(\mathrm{Cn})$ in pork loin muscle was developed. A good agreement was obtained between the two sets of data. These results proved that HILIC is an interesting alternative for the separation and quantification of nucleotides and nucleosides in complex matrices such as meat or poultry. This same method also showed good performance in the separation of guanosine, GMP, guanosine diphosphate, guanosine triphosphate and uric acid. The sphingolipid sphingomyelin was also analysed in raw meat samples of pork, beef and deer using HILIC chromatography (Fischbeck et al. 2009).

Cooked ham experiences an intense heat treatment that causes some relevant changes in most biochemical com- 
Food Anal. Methods

Fig. 1 Chromatograms corresponding to pork gluteus maximus (a) and masseter (b) muscles. Cn, Cr, CAR, ANS and muscles. Cn, Cr, CAR, ANS correspond to creatinine, creatine, carnosine, anserine and balenine. The column was an Atlantis Silica (Waters), $150 \mathrm{~mm} \times 4.6 \mathrm{~mm}, 3 \mu \mathrm{m}$. Left scale indicates $214-\mathrm{nm}$ measures for all compounds except creatinine (solid line), whereas right scale indicates $236-\mathrm{nm}$ absorbance for creatinine (dotted line
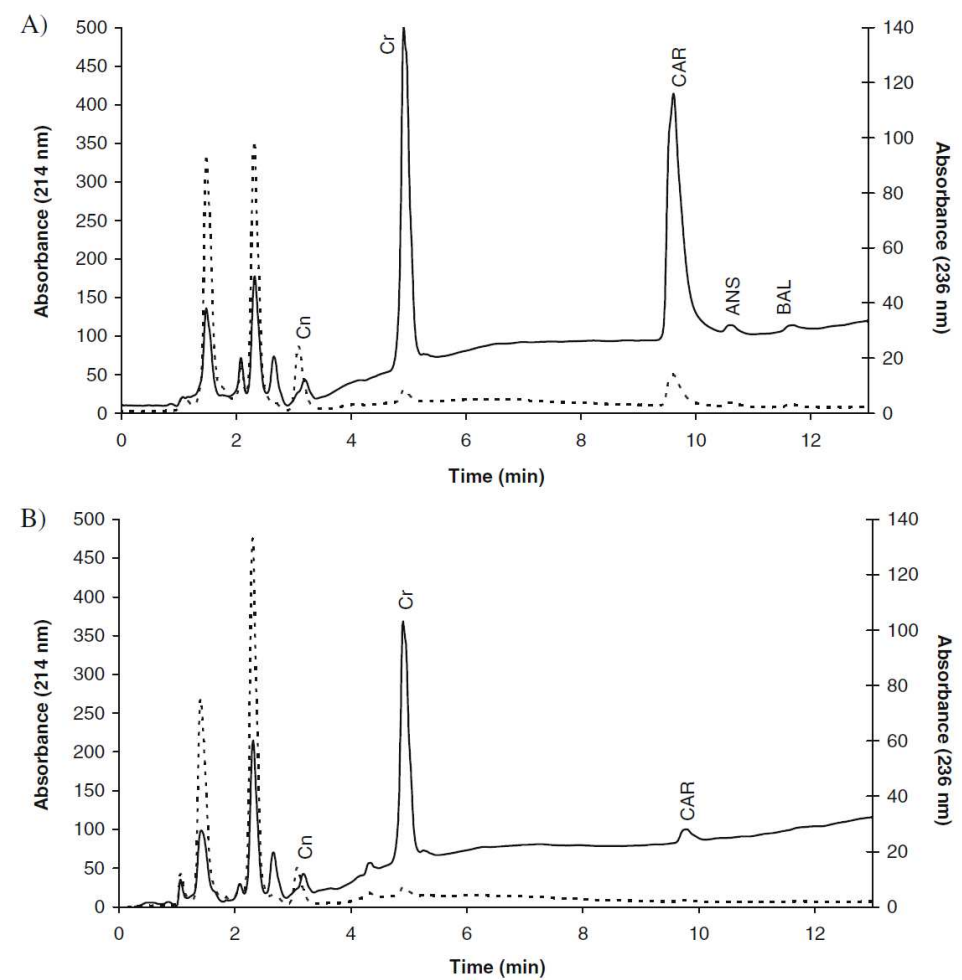

pounds. In fact, creatine turns into creatinine easily under heating conditions such as meat cooking through a nonenzymatic conversion. In this respect, HILIC methodology was used to evaluate the effect of different cooking methods

Fig. 2 Chromatogram corresponding to a cooked ham extract. $\mathrm{Cn}, \mathrm{Hx}+\mathrm{X}, \mathrm{INO}, \mathrm{GUA}$ AMP and IMP correspond to creatinine, hypoxanthine,

inosine, guanosine, adenosine monophosphate and inosine monophosphate, respectively. The column was a ZIC-pHILIC (SeQuant), $150 \mathrm{~mm} \times 4.6 \mathrm{~mm}$,

$5 \mu \mathrm{m}$

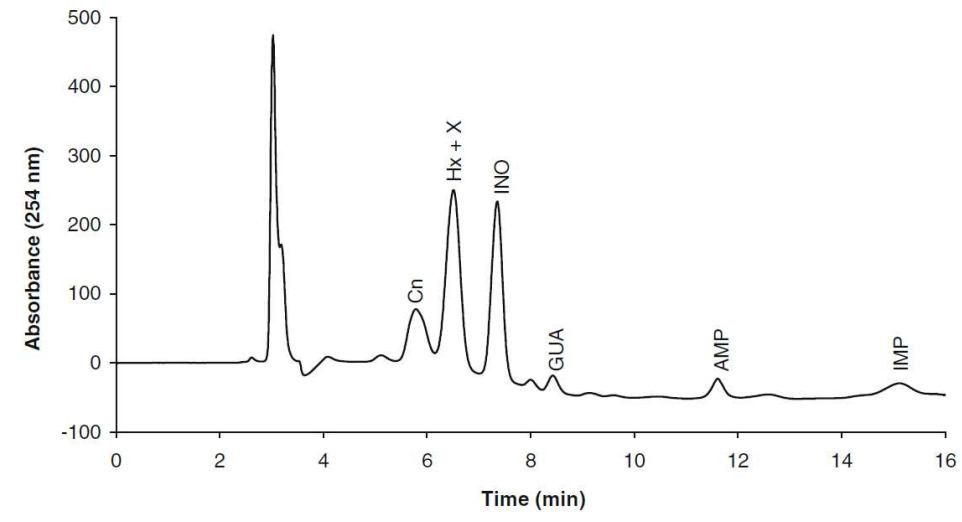

on creatine conversion to creatinine in cooked ham (Mora et al. 2008b). The results allowed the establishment of a correlation between the creatine/creatinine ratio and the effectiveness of the heat treatment in cooked ham processes.

$\underline{\underline{\text { Springer }}}$ 
Fig. 3 Chromatogram corresponding to a dry-cured ham with 7 months of ripening. $\mathrm{Cn}, \mathrm{Cr}, \mathrm{CAR}$, ANS and $\mathrm{BAL}$ correspond to creatinine, creatine, carnosine, anserine an balenine, respectively. The column was an Atlantis Silic (Waters), 150 in $3 \mu \mathrm{m}$. Left scale indicates 214-nm measures for all compounds except creatinine (solid line), whereas right scale indicates 236-nm absorbance for creatinine (dotted line)

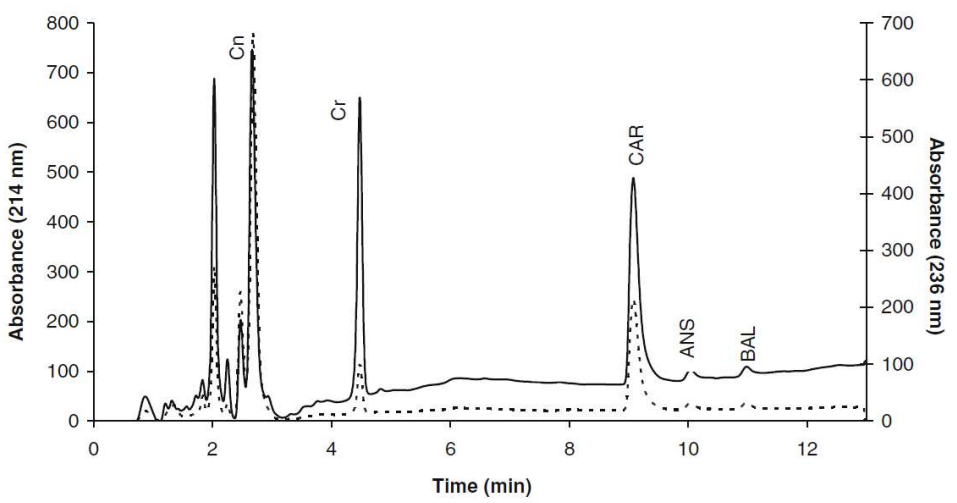

On the other hand, heating treatment also accelerates the enzymatic breakdown of most of the nucleotides, except some AMP and IMP, yielding respective nucleosides which are finally transformed into hypoxanthine. HILIC was also used for the separation of nucleotides and nucleosides in cooked ham. Thus, a good separation of inosine and guanosine, which were almost entirely transformed into hypoxanthine, as well as the peak corresponding to hypoxanthine + xanthine were obtained in cooked ham (see Fig. 2).

HILIC chromatography has also been used to study the evolution of creatine and creatinine during the processing of Spanish dry-cured ham (Mora et al. 2010). Creatine conversion to creatinine is not only influenced by temperature, but also by time of processing which is very long, up to 10 or more months, in dry-cured ham. During such a long time of processing, numerous physicochemical and

biochemical reactions take place (Toldrá 2006b; Estévez et al. 2007). This study clearly demonstrated that time of drycured processing had a significant effect on the contents of creatine and creatinine, which reached a plateau at about 7 months of processing. This fact indicates that creatine and creatinine contents could be a good estimation of the time of ripening.

The same chromatographic method previously described for the separation of histidine dipeptides, creatine and creatinine in raw meat was also used in a sample of drycured ham with 7 months of ripening (see Fig. 3), obtaining very good results in the isolation of these compounds. Finally, Fig. 4 shows the chromatogram of nucleosides corresponding to a dry-cured ham with 11 months of ripening. In this case, the enzymatic breakdown is quite more pronounced due to the long time of processing and ripening that allows for an intense enzymatic action,
Fig. 4 Chromatogram corresponding to a dry-cured han with 11 months of ripening $\mathrm{Cn}, \mathrm{Hx}+\mathrm{X}, \mathrm{INO}$ and GUA. correspond to creatinine, hypoxanthine, inosine, guanosine, adenosine monophosphate and inosine monophosphate, respectively. The column was a ZIC $p$ HILIC (SeQuant) $150 \mu \mathrm{m} \times 4.6 \mu \mathrm{m}, 5 \mu \mathrm{m}$

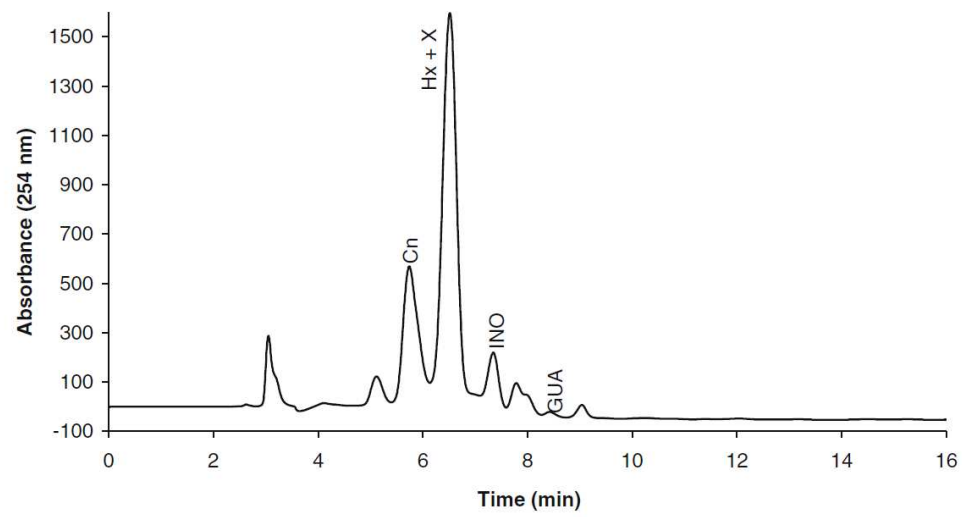

으 Springer 
resulting in the accumulation of hypoxanthine and xanthine that serve as good markers for a minimum time of processing. The identification and quantification of dipeptides carnosine, anserine and $\beta$-alanylglycine and nucleotides and nucleosides has also been carried out in chicken broth using hydrophilic interaction chromatography (Dunkel and Hofmann 2009), where these compounds could be related to the thick-sour and white-meaty odour sensation characteristic of this broth.

HILIC-based methods have proven to be a useful and valid alternative for the analysis of biochemical compounds like nucleotides and nucleosides, creatine and creatinine, sphingomyosin and dipeptides which are relevant quality markers during meat processing. So it can be used for quality control of complex food matrices like cured meat products. The analytical methodology is simple when compared with other rather conventional methods since it avoids complex cleanup and/or sample derivatisation procedures, and furthermore, it is compatible with mass spectrometry analysis in case it would be needed.

\section{Relevance of HILIC for the Analysis of Veterinary Drug} Residues in Meat and Poultry

HILIC has become very popular in bio-analytical applications for the detection of veterinary drugs residues in meat and poultry in recent years due to the widespread use of mass spectrometry coupled to HPLC. In this sense, HILIC mobile phases have good compatibility and give high sensitivity.

There are numerous analytical methods developed for controlling the presence of residues of veterinary drugs in meat and poultry in order to assure consumer protection against any potential harmful effects on humans (Toldra 2006b; Toldrá and Reig 2006; Reig and Toldrá 2008, 2009). A recent trend is observed towards the use of HILIC columns for the separation of polar compounds like antibiotics, and some examples are given below.

The analysis of aminoglycosides in porcine muscle tissue was performed by liquid-liquid extraction followed by solid-phase cleanup and further separation of the aminoglycosides by using a ZIC HILIC column (Sequant) and detection by tandem mass spectrometry (Ishii et al. 2008). Aminoglycosides are highly polar and are no retained by RP-HPLC, the use of ion-pair reagents being necessary, which may reduce the sensitivity of MS detectors. The use of HILIC methodology allowed a multi-residue determination with recoveries higher than $70 \%$ and low limits of quantification like $25 \mathrm{ng} / \mathrm{g}$ for gentamicin, $50 \mathrm{ng} / \mathrm{g}$ for spectinomycin, dihydrostreptomycin, kanamycin and apramycin and $100 \mathrm{ng} / \mathrm{g}$ for streptomycin and neomycin (Ishii et al. 2008).
The illegal use of nitrofurazone has implied the need for analytical methods for its determination. However, it is necessary to effectively separate it from azodicarbonamide that may generate false non-compliant results in the determination of nitrofurazone metabolites (Mulder et al. 2007). Since these compounds are very polar, standard C18 columns are rather difficult to provide enough retention but the use of a TSK gel amide 80 column (Tosoh, PA) gave a good separation, with elution at $12 \mathrm{~min}$ and discriminated effectively between both compounds with a limit of detection of only $10 \mathrm{ng} / \mathrm{g}$ (Mulder et al. 2007).

Prevention also includes the analysis of such antibiotics in the feed administered to farm animals. So carbadox and olaquindox were extracted with a matrix solid-phase dispersion and then analysed through a UPLC BEH HILIC column (Acquity, Waters, MA) under isocratic conditions and diode array detection obtaining much faster results than with other more usual methodologies (Kesiunaité et al. 2008).

Acknowledgements Grant AGL2007-65379-C02-01 from Ministry of Science and Innovation (Spain) and FEDER funds are fully acknowledged FPU Scholarship from Ministerio de Ciencin y Educación (Spain) to L.M. and scholarship from Consejo Nacional de Ciencia y Tecnología (CONACyT) and Colegio de Postgraduados (Mexico) to A.S.H-C. are fully acknowledged. This work was performed under the Associated Unit IAD (UPV)-IATA (CSIC).

\section{References}

Abe H, Okuma E (1995) Journal of the Japanese Society for Food Science and Technology-Nippon Shokuhin Kagaku Kogaku Kaishi 42:827-834

Ahn J, Bones J, Yu YQ, Rudd PM, Gilar M (2010) J Chromatogr B Anal Technol Biomed Life Sci 878:403-408

Aliani M, Farmer LJ (2005) J Agric Food Chem 53:6067-6072

Alpert AJ (1990) J Chromatogr 499:177-196

Andersen WC, Turnipseed SB, Karbiwnyk CM, Clark SB, Madson MR, Gieseker CA, Miller RA, Rummel NG, Reimschuessel R (2008) J Agric Food Chem 56:4340-4347

Aristoy MC, Toldrá F (1998) Meat Sci 50:327-332

Aristoy MC, Toldrá F (2004) Meat Sci 67:211-217

Aristoy MC, Soler C, Toldrá F (2004) Food Chem 84:485-491 Batlle N, Aristoy MC, Toldrá F (2000) J Food Sci 65:413-416

Batlle N, Aristoy MC, Toldrá F (2000) J Food Sci 65:413-416
Batlle N, Aristoy MC, Toldrá F (2001) J Food Sci 66:68-71

Batlle N, Aristoy MC, Toldrá F (2001) J Fo
Brown CE (1981) J Theor Biol 88:245-256

Calkins CR, Dutson TR, Smith GC, Carpenter ZL (1982) J Food Sci 47:1350-1353

Cambero MI, Pereira-Lima CI, Ordóñez JA, de Fernando GDG (2000) J Sci Food Agric 80:1519-1528

Chung WC, Tso SC, Sze ST (2007) J Chromatogr Sci 45:104-111

Ciminiello P, Dell'Aversano C, Fattorusso E, Forino M, Magno GS, Tartaglione L, Quilliam MA, Tubaro A, Poletti R (2005) Rapid Commun Mass Spectrom 19:2030-2038

Cornet M, Bousset J (1998) Meat Sci 51:215-219

Crush KG (1970) Comp Biochem Physiol 34:3

de Person M, Hazotte A, Elfakir C, Lafosse M (2005) J Chromatogr A 1081:174-181

Demant TW, Rhodes EC (1999) Sports Med 28:49-60

\section{으 Springer}


Dillehay DL, Webb SK, Schmelz EM, Merrill AH (1994) J Nutr 124:615-620

Dixon AM, Delinsky DC, Bruckner JV, Fisher JW, Bartlett MG (2004) J Liq Chromatogr Relat Technol 27:2343-2355

Dunkel A, Hofmann T (2009) J Agric Food Chem 57:9867-9877

Dunnett M, Harris RC (1992) J Chromatogr Biomed Appl 579:45-53 Dunnett M, Harris RC (1997) J Chromatogr B 688:47-55

Dunnett M, Harris RC, Orme CE (1991) Scand J Clin Lab Invest $51: 137-141$

Eckhardt ER, Wang DQH, Donovan JM, Carey MC (2001) Gastroenterology 120:A679-A680

Eckhardt ERM, Wang DQH, Donovan JM, Carey MC (2002) Gastroenterology 122:948-956

Estévez M, Morcuende D, Ventanas J, Ventanas S (2007) In: Toldrá F (ed) Handbook of fermented meat and poultry, 1st edn. Blackwell, Iowa, Chapter 38

Fenaille F, Parisod W, Vuichoud J, Tabet JC, Guy PA (2004) J Chromatogr A 1052:77-84

Fischbeck A, Kruger M, Blaas N, Humpf HU (2009) J Agric Food Chem 57:9469-9474

Fish WW (1991) J Agric Food Chem 39:1098-110

Fujita T, Hori Y, Otani T, Kunita Y, Sawa S, Sakai S, Tanaka Y, Takagahara I, Nakatani Y (1988) Agric Biol Chem 52:107-112

Takagahara $1, \mathrm{Nakath} Y(1988)$ Agnic Biol Cli $\mathrm{S}, 52.107-112$

Fi (1185:296-300 Grumbach ES, Diehl DM, Mccabe DR, Mazzeo JR, Neue UD (2003) Lc Gc Europe, 30-31

Grumbach ES, Wagrowski-Diehl DM, Mazzeo JR, Alden B, Iraneta PC (2004) Lc Gc N Am 22:1010

Guo Y, Gaiki S (2005) J Chromatogr A 1074:71-80

Guo Y, Huang AH (2003) J Pharm Biomed Anal 31:1191-1201

Hattula T, Kiesvaara M (1996) Lebensm Wiss Technol 29:135-139

Hellgren LI (2001) Eur J Lipid Sci Technol 103:661-667

Hertervig E, Nilsson A, Nyberg L, Duan RD (1997) Cancer 79:448-453

Hipkiss AR (1998) Int J Biochem Cell Biol 30:863-868

Hipkiss AR, Brownson C (2000) Cell Mol Life Sci 57:747-753

Hipkiss AR, Preston JE, Himsworth DTM, Worthington VC, Keown M, Michaelis J, Lawrence J, Mateen A, Allende L, Eagles PAM, Abbott NJ (1998) In: Harman D, Holliday R, Meydani M (eds) Towards prolongation of the healthy life span, vol 854. New York Academy of Sciences, New York, pp 37-53

Huang SC, Kuo JC (2000) Proc Natl Sci Counc Repub China B 4:193-201

Hughes MC, Kerry JP, Arendt EK, Kenneally PM, McSweeney PLH, O'Neill EE (2002) Meat Science 62:205-216

uttunen KM, Rautio J, Leppanen J, Vepsalainen J, Keski-Rahkonen P (2009) J Pharm Biomed Anal 50:469 474

Ishii R, Horie M, Chan W, MacNeil J (2008) Food Addit Contam A Chem Anal Control Exposure Risk Assess 25:1509-1519

Jiang W, Thunegbo FN (2009) Lc Gc Europe, 21-23

Jones NR, Murray CK, Murray J (1964) J Sci Food Agric 15:763

Karube I, Matsuoka H, Suzuki S, Watanabe E, Toyama K (1984) J Agric Food Chem 32:314-319

Kesiunaite G, Naujalis E, Padarauskas A (2008) J Chromatogr A 1209:83-87

Kovalova L, McArdell CS, Hollender J (2009) J Chromatogr A 1216:1100-1108

Lemonnier LA, Dillehay DL, Vespremi MJ, Abrams J, Brody E, Schmelz EM (2003) Arch Biochem Biophys 419:129-138

iu Y Xu X , Zhou GH (2007) Food Chem 102.22-26

Lojkova L, Klejdus B, Moravcova J, Kuban V (2006) Food Addit Contam 23:963-973

Luong JHT, Male KB (1992) Enzyme Microb Technol 14:125-130

Luong JHT, Male KB, Masson C, Nguyen AL (1992) J Food Sci 57:77-81
Martín L, Antequera T, Ventanas J, itez-Donoso R, Cordoba JJ (2001) Meat Sci 59:363-368

Merrill AH, Schmelz EM, Dillehay DL, Spiegel S, Shayman JA, Schroeder JJ, Riley RT, Voss KA, Wang E (1997) Toxicol Appl Pharmacol 142:208-225

Mora L, Sentandreu MA, Toldra F (2007) J Agric Food Chem 55:4664-4669

Mora L, Sentandreu MA, Toldrá F (2008a) Meat Sci 79:709-715

Mora L, Sentandreu MA, Toldrá F (2008b) J Agric Food Chem 56:11279-11284

Mora L, Hernández-Cázares AS, Aristoy MC, Toldrá F (2009) Food Chem, accepted

Mora L, Hernández-Cázares AS, Sentandreu MA, Toldrá F (2010) Meat Sci 84:384-389

Mulder PPJ, Beumer B, Van Rhijn JA (2007) Anal Chim Acta $586: 366-373$

Nyberg L, Duan RD, Nilsson A (2000) J Nutr Biochem 11:244-249 Oertel R, Neumeister V, Kirch W (2004a) J Chromatogr A 1058:197201

ertel R, Renner U, Kirch W (2004b) J Pharm Biomed Anal 35.633

kuma E, Abe H (1992) Comp Biochem Physiol A Physiol 102:37-41 Pais P, Salmon CP, Knize MG, Felton JS (1999) J Agric Food Chem 47:1098-1108

Pereira-Lima CI, Ordonez JA, de Fernando GDG, Cambero MI (2000) Eur Food Res Technol 210:165-172

Peru KM, Kuchta SL, Headley JV, Cessna AJ (2006) J Chromatogr A 1107:152-158

Reig M. Toldrá F (2008) Meat Sci 78:60-67

Reig M. Toldrá F (2009) In: Nollet LML. Toldrá F (eds) Handbook of muscle foods analysis, 1 st edn. CRC, Boca Raton, pp 837-854

Rotzoll N, Dunkel A, Hofmann T (2005) J Agric Food Chem 53:4149-4156

Saito T, Araki K, Matsuyoshi M (1959) Bull Jpn Soc Sci Fish, 749-750 Schlichtherle-Cerny H, Grosch W (1998) Z Lebensm Unters Forsch A Food Res Tech 207:369-376

schlichtherle-Cerny H, Affolter M, Cerny C (2003) Anal Chem 75:2349-2354

Schmelz EM, Merrill AH (1998) Nutrition 14:717-719

Schmelz EM, Dillehay DL, Webb SK, Reiter A, Adams J, Merrill AH (1996) Cancer Res 56:4936-4941

schmelz EM, Bushnev AS, Dillehay DL, Liotta DC, Merrill AH (1997) Nutr Cancer Int J 28:81-85

Schmelz EM, Sullards MC, Dillehay DL, Merrill AH (2000) J Nutr 130:522-527

Simon KW, Roberts PC, Vespremi MJ, Manchen S, Schmelz EM (2009) Mol Nutr Food Res 53:332-340

Strege MA (1998) Anal Chem 70:2439-2445

Tikk M, Tikk K, Torngren MA, Meinert L, Aaslyng MD, Karlsson AH, Andersen HJ (2006) J Agric Food Chem 54:7769-7777

Toldrá F (2006a) Handbook of food science, technology and engineering. $28-1-28-18$

Toldrá F (2006b) Trends Food Sci Technol 17:164-168

Toldrá F, Reig M (2006) Trends Food Sci Technol 17:482-489

Tranberg M, Stridh MH, Jilderos B, Weber SG, Sandberg M (2005) Anal Biochem 343:179-182

Volpe G, Mascini M (1996) Talanta 43:283-289

Wyss M, Kaddurah-Daouk R (2000) Physiol Rev 80:1107-1213

Yano Y, Kataho N, Watanabe M, Nakamura T, Asano Y (1995) Food Chem 52:439-445

Yoshida T (2004) J Biochem Biophys Meth 60:265-280

Zheng MM, Zhang MY, Peng GY, Feng YQ (2008) Anal Chim Acta 625:160-172

Zywicki B, Catchpole G, Draper J, Fiehn O (2005) Anal Biochem 336:178-186 


\section{Anexo D}

SCIBNCI

MEAT SCIENCE

SCIRNCE

SCIBNCE

SCIENCE

SCIBNCI

SCIBNCE

SCIENCH

SCIENCE

Nucleotides and their degradation products during processing of dry-cured ham, measured by HPLC and an enzyme sensor

Aleida S. Hernández-Cázares, María-Concepción Aristoy, Fidel Toldrá

Aceptado, en pruebas de imprenta 

Meat Science xxx (2010) xxx-xxx. Aceptado

Contents lists available at ScienceDirect

Meat Science

journal homepage: www.elsevier.com/locate/meatsci

Original article

Nucleotides and their degradation products during processing of dry-cured ham, measured by HPLC and an enzyme sensor

Aleida S. Hernández-Cázares, María-Concepción Aristoy, Fidel Toldrá *

Instituto de Agroquímica y Tecnología de Alimentos CSIC, Av. Agustín Escardino 7, P.O. Box 73, 46980 Paterna, Valencia, Spain

\begin{abstract}
During the dry cured ham processing many biochemical reactions take place and have a high impact on final product quality. The aim of this work was to study in which way the nucleotide degradation during processing of dry-cured ham is affected when using three types of salting $(100 \% \mathrm{NaCl} ; 50 \% \mathrm{NaCl}$ and $50 \% \mathrm{KCl} ; 55 \% \mathrm{NaCl}, 25 \% \mathrm{KCl}, 15 \% \mathrm{CaCl}_{2}$ and $5 \% \mathrm{MgCl}_{2}$ ). Divalent salts in the salting mixture depressed the breakdown rate from the beginning of the process (salting and post-salting) up to the ripening stage (7 months) when nucleosides inosine (Ino), hypoxanthine $(\mathrm{Hx})$ and xanthine $(\mathrm{X})$ concentrations matched for the three treatments. The evolution of $\mathrm{Hx}$ and $\mathrm{Hx}+\mathrm{X}$ analysed by high performance liquid chromatography (HPLC) and an enzyme sensor, respectively, was determined for considering them as potential biochemical marker. The length and temperature conditions along the curing time did not affect the $\mathrm{Hx}$ stability. The usefulness of enzyme sensor was confirmed and constitutes a practical tool to determine $\mathrm{Hx}+\mathrm{X}$ in dry-cured ham, as an index of minimum curing time. A good agreement between enzyme sensor and HPLC data was observed with a correlation coefficient of 0.9744 and a regression equation of $y=1.0152 x-0.3556$.
\end{abstract}

Keywords: Dry-cured ham, nucleotides, enzyme sensor, xathine oxidase, hypoxanthine, salt. 